\title{
BROMINE PHOTOELIMINATION FROM ORGANOPLATINUM(IV) COMPLEXES
}

\author{
A Dissertation \\ presented to \\ the Faculty of the Graduate School \\ at the University of Missouri - Columbia \\ In Partial Fulfillment \\ of the Requirements for the Degree \\ Doctor of Philosophy \\ by \\ ALICE RAPHAEL KARIKACHERY \\ Prof. PAUL R. SHARP, Dissertation Supervisor \\ July 2014
}


Reproduced with permission from Karikachery AR, Lee HB, Masjedi M, Ross A, Moody MA, Cai X, Chui M, Hoff CD, Sharp PR.

Inorganic Chemistry. 2013 Apr 1;52(7):4113-9. Mar 2013.

Copyright (C) 2013 Inorganic Chemistry

(C) Copyright by Alice Raphael Karikachery

2013

All Rights Reserved 
The undersigned, appointed by the dean of the Graduate School, have examined the dissertation entitled

\section{BROMINE PHOTOELIMINATION FROM ORGANOPLATINUM(IV) COMPLEXES}

presented by Alice Raphael Karikachery

a candidate for the degree of Doctor of Philosophy

and hereby certify that, in their opinion, it is worthy of acceptance.

Prof. Paul R. Sharp

Prof. Carol A. Deakyne

Prof. Steven W. Keller

Prof. Stephen J. Lombardo 


\section{ACKNOWLEDGEMENTS}

First and foremost, I want to extend my heartfelt gratitude to Prof. Paul R. Sharp. Thank you very much for accepting me in your group and mentoring me. It has been a tremendous opportunity to learn from an excellent educator, astute scientist and a great mentor. Facilitating clear communication, always available for discussions and troubleshooting research problems; it has been a joy and a fantastic learning experience as well. To emulate your example whilst pursuing my scientific career will be a worthy goal. Thank you very much for providing research assistantship funding as well. Your support and encouragement throughout the entire program is highly appreciated.

I am very thankful to Prof. Carol A. Deakyne, Prof. Steven W. Keller and Prof. Stephen J. Lombardo for being on my committee. Thank you very much for your support and guidance. I am extremely thankful for all the discussions, comments and feedback. I can't thank Prof. Deakyne enough for all the wonderful discussions and encouragement she gave me.

I would like to express special gratitude to our collaborator Prof. Carl D. Hoff. His group's calorimetric measurements and inputs have been very valuable. I want to acknowledge Dr. Han Baek Lee a former group member, whose discovery of bromine

photoelimination from Platinum (IV) complexes, steered us into the realms of photochemistry. I am also thankful to all my colleagues, present and past members of our 
group: Dr. Bao-yu Wang, Dr. Jianguo Wu, Dr. Nripen Chanda, Dr. Anupam Sigh, Dr. Robert Robinson Jr., Dr. Nandita Malathi Weliange, Dr. Morgan Moody, Lakshmi Nilakantan, Yang Li, Andreas Ross, Liping Chen, Dr. Mehdi Masjedi, Tharushi Perera and Lasantha Wickramasinghe.

I would like to express my gratitude to Dr. Wei G. Wycoff for NMR support. She was always available and very helpful. I am also extremely grateful to Dr. Charles Barnes for single crystal x-ray crystallography.

I am very grateful to the Department of Chemistry and University of Missouri, Columbia for giving me this wonderful opportunity to pursue my graduate studies and providing teaching assistantship funding. I want to specially thank Jerry Brightwell and the MU international center for answering all my queries and supporting me throughout the graduate school process. I want to acknowledge 'The US Department of Energy' for funding our research endeavors.

I want to thank my parents, brother and sister for all their love, help and encouragement. I also want to thank my husband, Nishant, for his love and companionship. You have been a pillar of support and strength. I also want to thank all my friends in Columbia. 


\section{TABLE OF CONTENTS}

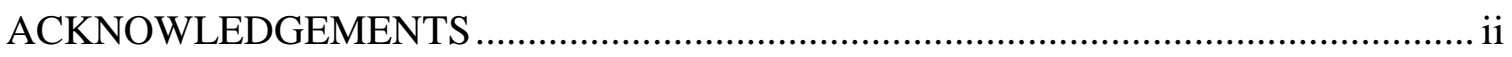

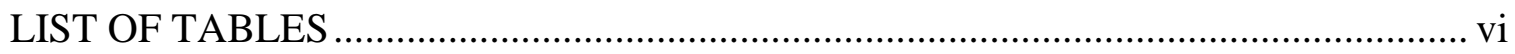

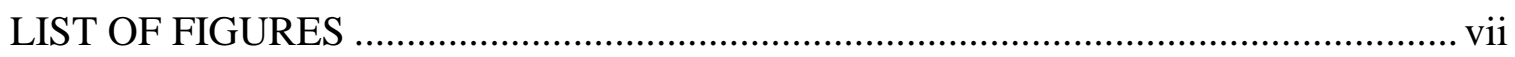

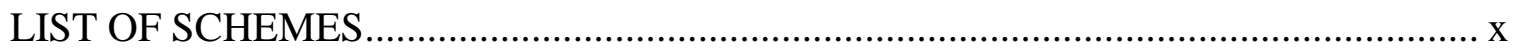

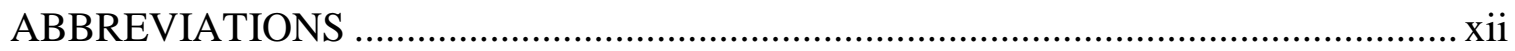

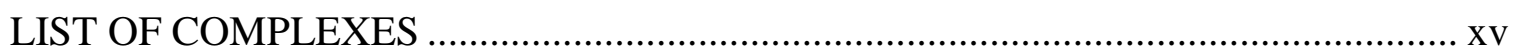

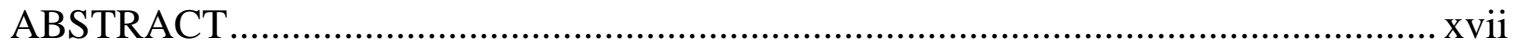

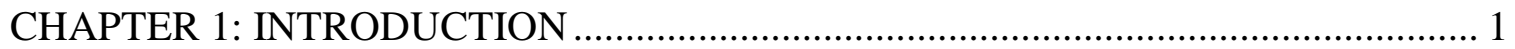

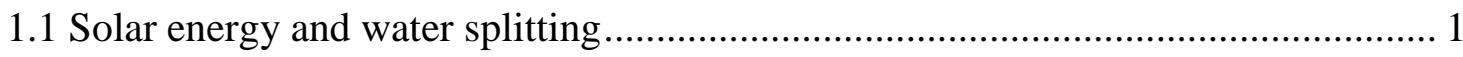

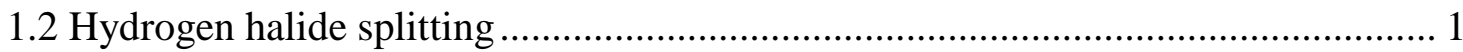

1.3 Metal catalysts for HX splitting ………………............................................ 2

1.4 Homogenous catalysis and functionalization of PAC ......................................... 5

1.5 Halogen elimination literature review ................................................................. 7

1.6 Research summary ................................................................................................ 10

CHAPTER 2: BROMINE PHOTOELIMINATION FROM PLATINUM(IV)

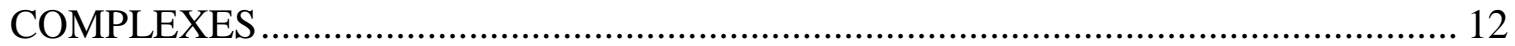

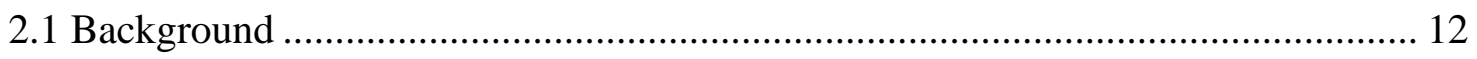

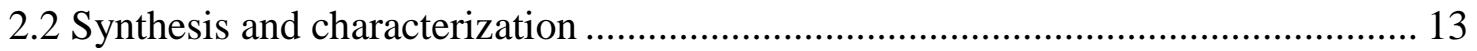

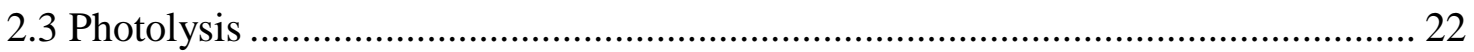

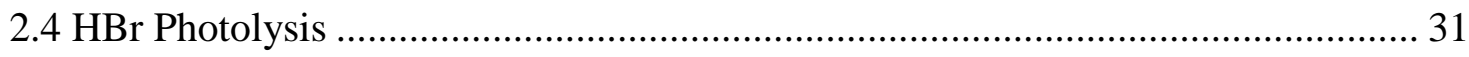

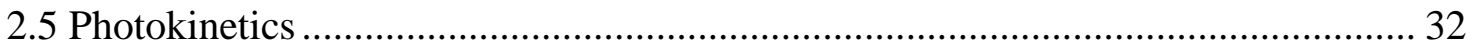

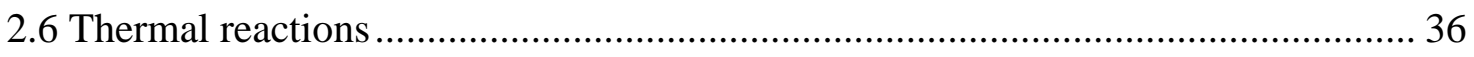

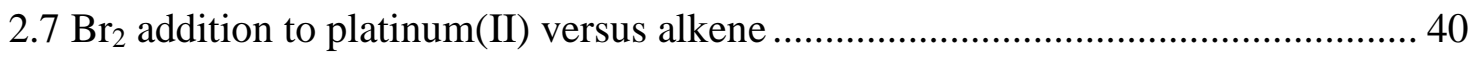

2.8 Low temperature photoemission ....................................................................... 40

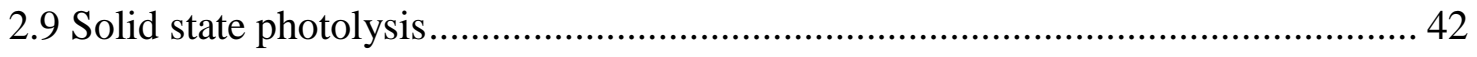

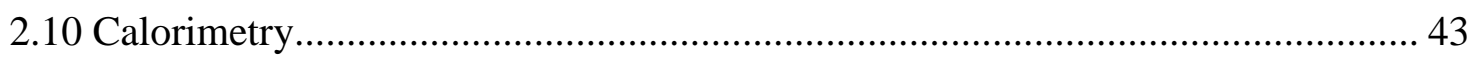

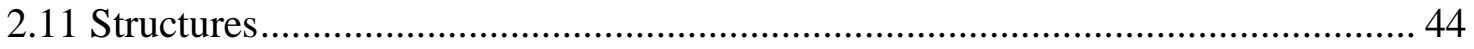

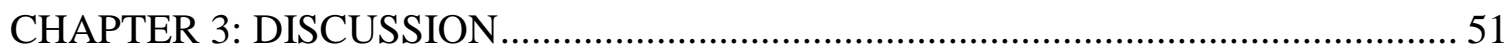




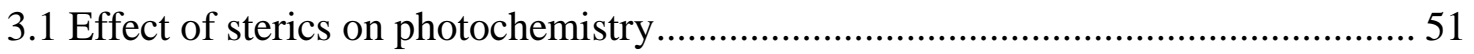

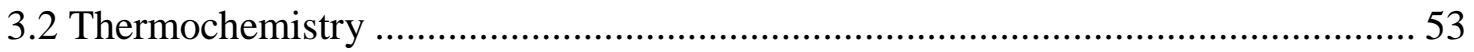

$3.3 \mathrm{Br}_{2}$ addition to platinum(II) versus alkene comparison ..................................... 55

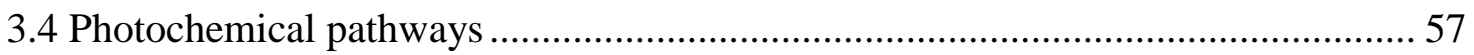

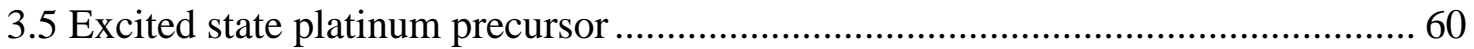

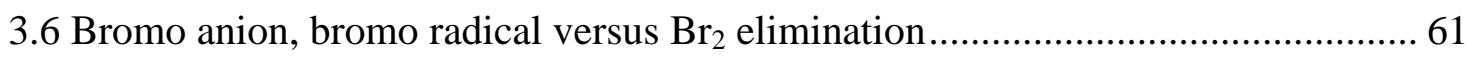

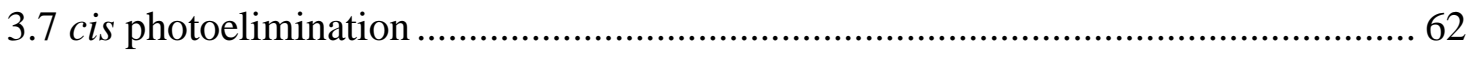

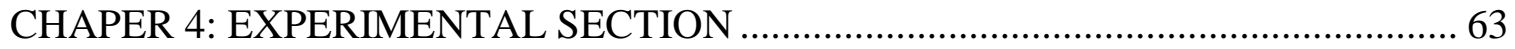

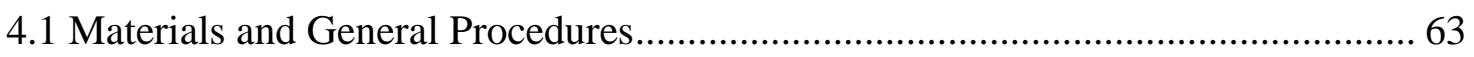

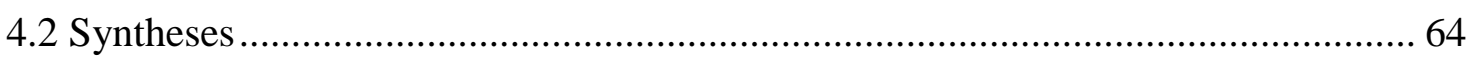

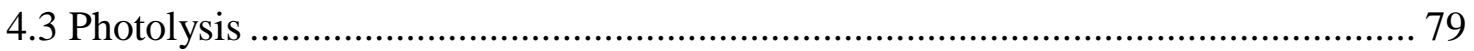

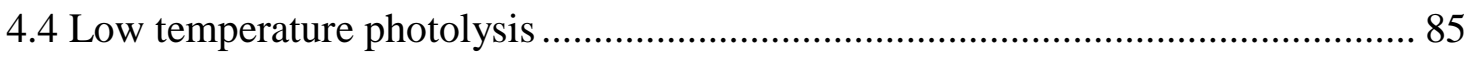

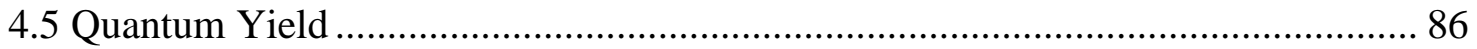

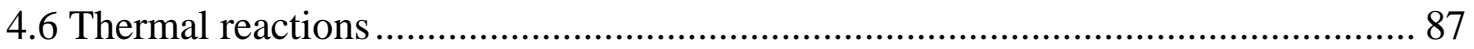

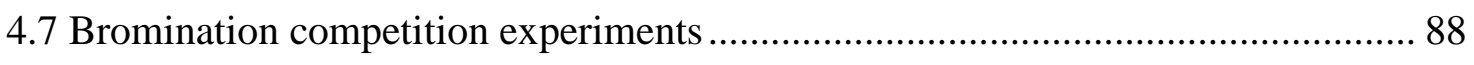

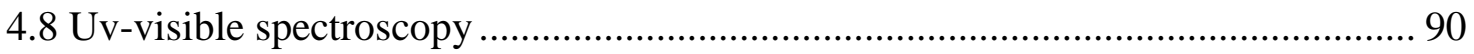

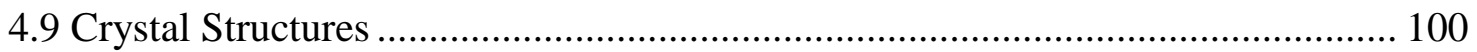

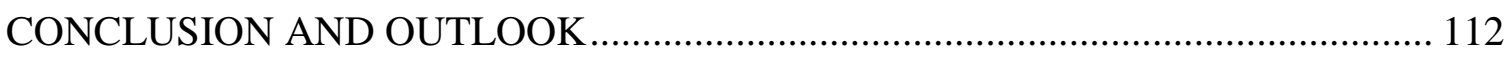

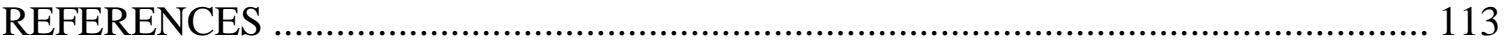

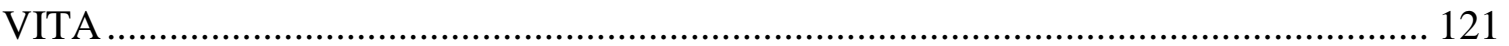




\section{LIST OF TABLES}

Table 1.4.1. Photolysis product yields for 2(1-Nap) and 2(Phen) in toluene and with added bromine traps

Table 2.3.1. Photolysis product yields for 2(1-Nap) with cis-2-hexene in $\mathrm{CD}_{2} \mathrm{Cl}_{2}$ and $\mathrm{CDCl}_{3}$ at $313 \mathrm{~nm}$

Table 2.3.2. Quantum yields $(\Phi)$ at $313 \mathrm{~nm}$ for conversion of $\mathbf{2}$ to $\mathbf{1}$ in the presence of 1hexene 26

Table 2.3.3. Photolysis product yields ${ }^{\mathrm{a}}$ for trans $-\mathrm{Pt}\left(\mathrm{PEt}_{3}\right)_{2}(\mathrm{Br})_{4}(\mathbf{2}(\mathrm{Br}))^{\mathrm{b}}$ with $2,3-$

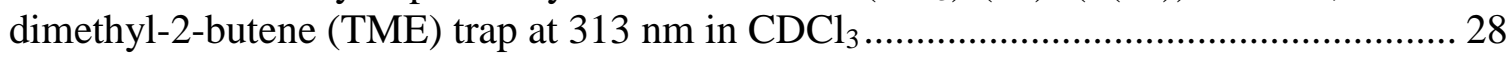

Table 2.3.4. Photolysis product yields ${ }^{a}$ for trans- $\mathrm{Pt}\left(\mathrm{PEt}_{3}\right)_{2}(\mathrm{Br})_{3}(4-\mathrm{BrNap})(2(\mathrm{BrNap}))^{\mathrm{b}}$ with 2,3-dimethyl-2-butene (TME) trap at $313 \mathrm{~nm}$ in $\mathrm{CDCl}_{3}$

Table 2.10.1. Thermodynamic values ( $\mathrm{kcal} / \mathrm{mol})$ for the bromination of $\mathbf{1}$ and $\mathbf{1}$ '... 43

Table 2.11.1. Metrical parameters for $2\left(\mathrm{R}=\mathrm{BrNap},{ }^{\mathrm{b}} \mathrm{BrMeO}_{2} \mathrm{Ph},{ }^{\mathrm{b}} \mathrm{BriPrOPh}, \mathrm{DiBrPt}\right) 50$

Scheme 3.5.1 Reactivity of platinum excited state 60

Table 4.9.1. Crystal data and structure refinement for di-trans-Pt(PEt3)2(Br)3(6,7-

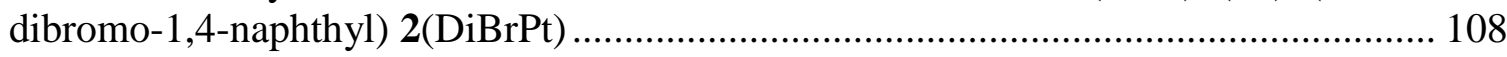

Table 4.9.2. Crystal data and structure refinement for $\mathrm{Pt}($ depe $)(\mathrm{Br}) 4$ 2(depe) 109

Table 4.9.3. Crystal data and structure refinement for trans $-\mathrm{Pt}\left(\mathrm{PEt}_{3}\right)_{2}(\mathrm{Br})_{3}(5$-bromo-2isopropoxyphenyl) 2(BriPrOPh). 110

Table 4.9.4. Crystal data and structure refinement for di-trans-Pt(PEt3)2(Br)(1,4naphthyl) 1(DiPt) 


\section{LIST OF FIGURES}

Figure 2.5.1. Kinetic plot (tablefrom ${ }^{31} \mathrm{P}$ ) for the photolysis of trans-Pt $\left(\mathrm{PEt}_{3}\right)_{2}(\mathrm{Br})_{3}(4-$

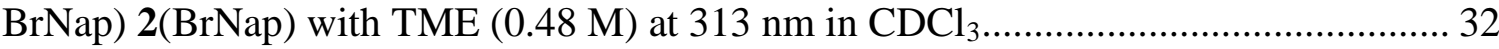

Figure 2.5.2. Kinetic plot (from ${ }^{31} \mathrm{P}$ ) for the photolysis of trans- $\mathrm{Pt}\left(\mathrm{PEt}_{3}\right)_{2}(\mathrm{Br})_{3}(4-\mathrm{BrNap})$

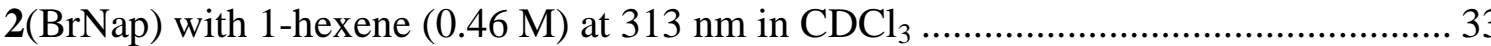

Figure 2.5.3. Kinetic plot (from ${ }^{31} \mathrm{P}$ ) for the photolysis of trans- $\mathrm{Pt}\left(\mathrm{PEt}_{3}\right)_{2}(\mathrm{Br})_{3}(4-\mathrm{BrNap})$ 2(BrNap) with 1-hexene $(0.46 \mathrm{M})$ at $313 \mathrm{~nm}$ in $\mathrm{CDCl}_{3}$ in the presence of oxygen 34

Figure 2.5.4. Kinetic plot (from ${ }^{31} \mathrm{P}$ and ${ }^{1} \mathrm{H} \mathrm{NMR}$ ) for the photolysis of trans$\mathrm{Pt}\left(\mathrm{PEt}_{3}\right)_{2}(\mathrm{Br})_{3}(4-\mathrm{BrNap}) 2(\mathrm{BrNap})$ with 1-hexene $(0.46 \mathrm{M})$ at $380 \mathrm{~nm}$ in $\mathrm{CDCl}_{3}$ 35

Figure 2.5.5. Kinetic plot (from ${ }^{31} \mathrm{P}$ and ${ }^{1} \mathrm{H}$ NMR) for the photolysis of trans$\mathrm{Pt}\left(\mathrm{PEt}_{3}\right)_{2}(\mathrm{Br})_{3}(4-\mathrm{BrNap}) 2(\mathrm{BrNap})$ with 1-hexene $(0.46 \mathrm{M})$ in the presence of trans$\mathrm{Pt}\left(\mathrm{PEt}_{3}\right)_{2}(\mathrm{Br})$ (4-BrNap) 1(BrNap) at $380 \mathrm{~nm}$ in $\mathrm{CDCl}_{3}$. (Beginning 2(BrNap):1(BrNap) ratio is $44: 56)$

Figure 2.6.1. Kinetic plot (from ${ }^{31} \mathrm{P}$ and ${ }^{19} \mathrm{~F}$ NMR) for the 1-hexene dark reaction of trans $-\mathrm{Pt}\left(\mathrm{PEt}_{3}\right)_{2}(\mathrm{Br})_{3}\left(\mathrm{CF}_{3} \mathrm{Ph}\right) 2\left(\mathrm{CF}_{3} \mathrm{Ph}\right)(4.3 \mathrm{mM})$ at $300 \mathrm{~K}$ and [1-hexene] $=0.096 \mathrm{M}$ in $\mathrm{CDCl}_{3}$

Figure 2.6.2. Kinetic plot (from ${ }^{31} \mathrm{P}$ and ${ }^{19} \mathrm{~F}$ NMR) for the 1-hexene dark reaction of trans $-\mathrm{Pt}\left(\mathrm{PEt}_{3}\right)_{2}(\mathrm{Br})_{3}\left(\mathrm{CF}_{3} \mathrm{Ph}\right) 2\left(\mathrm{CF}_{3} \mathrm{Ph}\right)(4.3 \mathrm{mM})$ at $300 \mathrm{~K}$ and [1-hexene] $=0.19 \mathrm{M}$ in $\mathrm{CDCl}_{3}$

Figure 2.6.3. Kinetic plot (from ${ }^{31} \mathrm{P}$ and ${ }^{1} \mathrm{H}$ NMR) for the 1-hexene dark reaction of trans $-\mathrm{Pt}\left(\mathrm{PEt}_{3}\right)_{2}(\mathrm{Br})_{3}\left(\mathrm{CF}_{3} \mathrm{Ph}\right) 2\left(\mathrm{CF}_{3} \mathrm{Ph}\right)(4.2 \mathrm{mM})$ at $300 \mathrm{~K}$ and [1-hexene] $=0.38 \mathrm{M}$ in $\mathrm{CDCl}_{3}$

Figure 2.6.4. Kinetic plot (from ${ }^{31} \mathrm{P}$ ) for the 1-hexene dark reaction of trans-

$\mathrm{Pt}\left(\mathrm{PEt}_{3}\right)_{2}(\mathrm{Br})_{3}(4-\mathrm{BrNap}) 2(\mathrm{NapBr})(3.1 \mathrm{mM})$ at $325 \mathrm{~K}$ and $\left[1\right.$-hexene] $=0.31 \mathrm{M}$ in $\mathrm{CDCl}_{3}$

Figure 2.8.1. Photoemission spectrum of trans- $\mathrm{Pt}\left(\mathrm{PEt}_{3}\right)_{2}(\mathrm{Br})$ (4-bromo-1-naphthyl) 1(BrNap) in 2-methyltetrahydrofuran glass at $77 \mathrm{~K}$ with $360 \mathrm{~nm}$ excitation

Figure 2.8.2 Emission decay at $520 \mathrm{~nm}$ for trans- $\mathrm{Pt}\left(\mathrm{PEt}_{3}\right)_{2}(\mathrm{Br})(4-$ bromo-1-naphthyl) $\mathbf{1}(\mathrm{BrNap})$ in 2-methyltetrahydrofuran glass at $77 \mathrm{~K}$, lifetime $=332(1) \mu \mathrm{s}, \lambda($ excitation$)=$ $360 \mathrm{~nm}$, gate time $=0.1 \mathrm{~ms}$ and delay time $=0.1 \mathrm{~ms}$

Figure 4.8.1 Electronic absorption spectrum of trans- $\mathrm{Pt}\left(\mathrm{PEt}_{3}\right)_{2}(\mathrm{Br})_{3}(1-$ phenyl $) 2(\mathrm{Ph})$ in $\mathrm{CH}_{2} \mathrm{Cl}_{2}$ 
Figure 4.8.3. Electronic absorption spectrum of trans $-\mathrm{Pt}\left(\mathrm{PEt}_{3}\right)_{2}(\mathrm{Br})_{4} \mathbf{2}(\mathrm{Br})$ in $\mathrm{CH}_{2} \mathrm{Cl}_{2}$.. 91

Figure 4.8.4. Electronic absorption spectrum of trans- $\mathrm{Pt}\left(\mathrm{PEt}_{3}\right)_{2}(\mathrm{Br})(2-$

(trifluoromethy)phenyl) $\mathbf{1}\left(\mathrm{CF}_{3} \mathrm{Ph}\right)$ in $\mathrm{CH}_{2} \mathrm{Cl}_{2}$ 91

Figure 4.8.5. Electronic absorption spectrum of trans- $\mathrm{Pt}\left(\mathrm{PEt}_{3}\right)_{2}(\mathrm{Br})_{3}(2-$ (trifluoromethy)phenyl) 2(CF3Ph) in $\mathrm{CH}_{2} \mathrm{Cl}_{2}$ 92

Figure 4.8.6. Electronic absorption spectrum of trans- $\mathrm{Pt}\left(\mathrm{PEt}_{3}\right)_{2}(\mathrm{Br})(2$-aminophenyl) $1(\mathrm{NPh})$ in $\mathrm{CH}_{2} \mathrm{Cl}_{2}$ 92

Figure 4.8.7. Electronic absorption spectrum of trans- $\mathrm{Pt}\left(\mathrm{PEt}_{3}\right)_{2}(\mathrm{Br})_{3}(3,5$-dibromo-2aminophenyl) $2(\mathrm{BrNPh})$ in $\mathrm{CH}_{2} \mathrm{Cl}_{2}$ 93

Figure 4.8.8. Electronic absorption spectrum of trans-Pt $\left(\mathrm{PEt}_{3}\right)_{2}(\mathrm{Br})(2,6-$ dimethoxyphenyl) $\mathbf{1}\left(\mathrm{MeO}_{2} \mathrm{Ph}\right)$ in $\mathrm{CH}_{2} \mathrm{Cl}_{2}$ 93

Figure 4.8.9. Electronic absorption spectrum of trans- $\mathrm{Pt}\left(\mathrm{PEt}_{3}\right)_{2}(\mathrm{Br})_{3}(3,5$-dibromo-2,6-

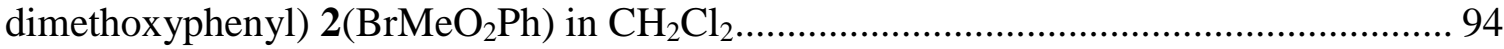

Figure 4.8.10. Electronic absorption spectrum of $\mathbf{1}(1-\mathrm{Nap})$ in $\mathrm{CH}_{2} \mathrm{Cl}_{2} \ldots \ldots \ldots \ldots \ldots \ldots \ldots . . . . . . . . . . .94$

Figure 4.8.11. Electronic absorption spectrum of 2(1-Nap) in hexane .......................... 95

Figure 4.8.12. Electronic absorption spectrum of $\mathbf{1}(\mathrm{BrNap})$ in $\mathrm{CH}_{2} \mathrm{Cl}_{2} \ldots \ldots \ldots \ldots \ldots \ldots \ldots . . . . . . . . . .95$

Figure 4.8.13. Electronic absorption spectrum of 2 (BrNap) in $\mathrm{CH}_{2} \mathrm{Cl}_{2} \ldots \ldots \ldots \ldots \ldots \ldots \ldots . . . . . . . . .96$

Figure 4.8.14. Electronic absorption spectrum of $2(\mathrm{Phen})$ in $\mathrm{CH}_{2} \mathrm{Cl}_{2} \ldots \ldots \ldots \ldots \ldots \ldots \ldots . . . . . . . . . . . .66$

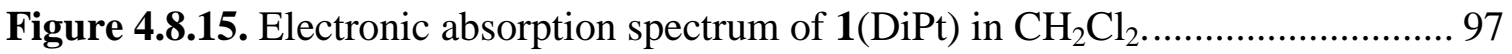

Figure 4.8.16. Electronic absorption spectra of 1(BrNap), 1(1-Nap) and $\mathbf{1}(\mathrm{DiPt})$ in $\mathrm{CH}_{2} \mathrm{Cl}_{2}$

Figure 4.8.17. Electronic absorption spectra of 2(1-Nap), 2(2-Nap) and 2(BrNap) in $\mathrm{CH}_{2} \mathrm{Cl}_{2}$ 98

Figure 4.8.18. Electronic absorption spectra of 2(1-Nap), 2(Phen), 2(Ph) and 2(Br) in $\mathrm{CH}_{2} \mathrm{Cl}_{2}$ 98

Figure 4.8.19. Electronic absorption spectra of 2(1-Nap) in DMF and $\mathrm{CH}_{2} \mathrm{Cl}_{2}$. 99

Figure 4.8.20. Electronic absorption spectra of 2(Phen) in hexane, $\mathrm{CH}_{2} \mathrm{Cl}_{2}$ and $\mathrm{DMF} \ldots 99$ 
Figure 4.9.1. XSeed/POV-Ray drawing of 1(NPh). Carbon bonded hydrogen atoms omitted. Atoms are drawn as 50\% probability ellipsoids. H1A and H1B were refined isotropically

Figure 4.9.3. XSeed/POV-Ray drawing of $1\left(\mathrm{BrMeO}_{2} \mathrm{Ph}\right)$. Hydrogen atoms omitted. Atoms are drawn as $50 \%$ probability ellipsoids 103

Figure 4.9.4. XSeed/POV-Ray drawing of $2\left(\mathrm{BrMeO}_{2} \mathrm{Ph}\right)$. Hydrogen atoms omitted. Atoms are drawn as $50 \%$ probability ellipsoids.

Figure 4.9.5. XSeed/POV-Ray drawing of 2(Br). Hydrogen atoms omitted. Atoms are drawn as $50 \%$ probability ellipsoids. Named and unnamed atoms are inversion related 105

Figure 4.9.6. XSeed/POV-Ray drawing of 2(BrNPh) 106

Figure 4.9.7. XSeed/POV-Ray drawing of $\mathbf{2}(\mathrm{BrNapBr})$. Hydrogen atoms omitted. Atoms are drawn as $50 \%$ probability ellipsoids. There is crystallographic disorder at C6 107 


\section{LIST OF SCHEMES}

Scheme 1.3.1. Photocatalytic HX splitting cycle for a monometallic catalyst................. 3

Scheme 1.3.2. Photocatalytic HX splitting cycle for a bimetallic catalyst...................... 4

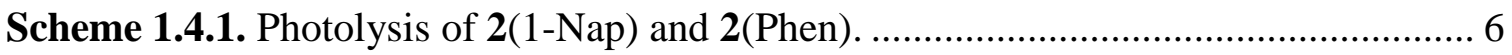

Scheme 1.5.1. Bimetallic platinum complex............................................................... 8

Scheme 1.5.2. Bimetallic gold complex ........................................................... 9

Scheme 1.5.3. Dinuclear tellurium platinum complex ............................................ 9

Scheme 2.2.1. Ortho-substituted phenyl and 2-naphthyl platinum(II) and platinum(IV)

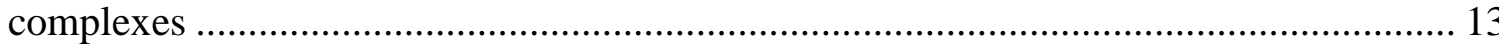

Scheme 2.2.2. Synthesis of substituted phenyl and 2-naphthyl platinum(II) complexes. 14

Scheme 2.2.3. Synthesis of ortho-substituted phenyl and 2-naphthyl platinum(IV)

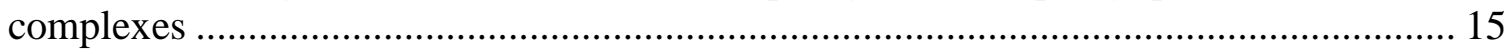

Scheme 2.2.4. Phenyl, naphthyl and phenanthryl Pt(II) and Pt(IV) complexes.............. 16

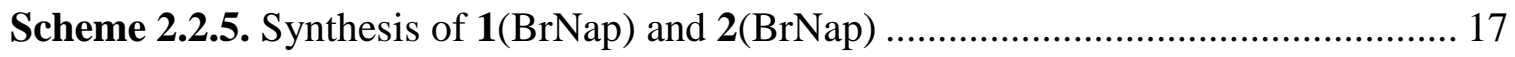

Scheme 2.2.6. Synthesis of diplatinum complexes .................................................. 18

Scheme 2.2.7. Platinum(II) and platinum(IV) phosphine complexes ............................ 19

Scheme 2.2.8. trans-phosphine platinum(IV) complex........................................... 19

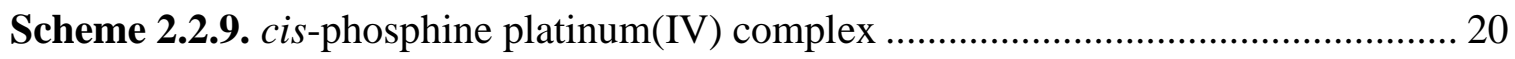

Scheme 2.2.10. Chelated phosphine platinum(IV) complex .................................... 20

Scheme 2.2.11. Dibrominated naphthyl platinum(IV) complexes .............................. 21

Scheme 2.3.1. Diplatinum complex photolysis .................................................... 25

Scheme 2.3.2. Alkene trap competition experiment................................................. 30

Scheme 2.4.1. $\mathrm{HBr}$ addition to platinum(II) complex .............................................. 31

Scheme 3.1.2. peri-hydrogen sterics in platinum(II) anthracenyl complex ................... 52 


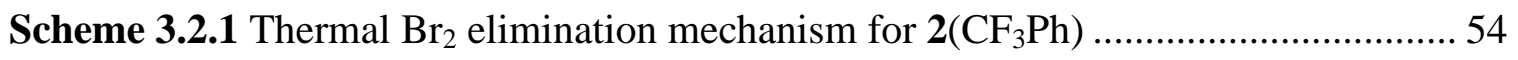

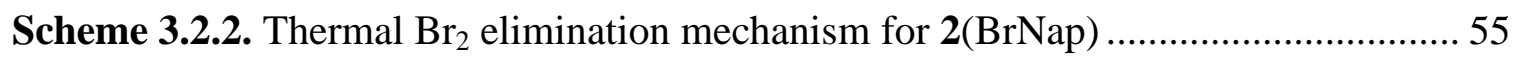

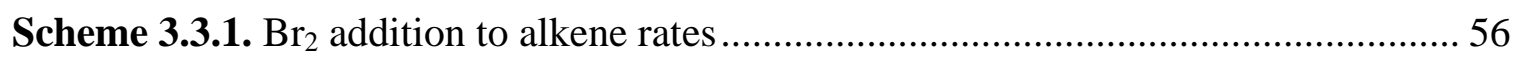

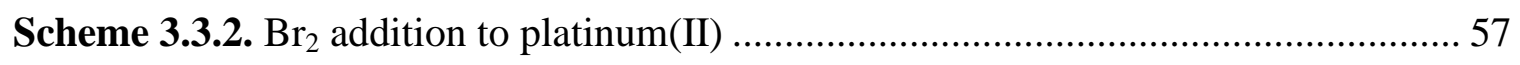

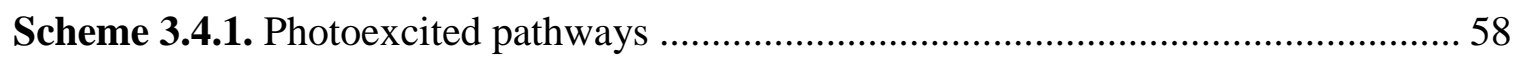

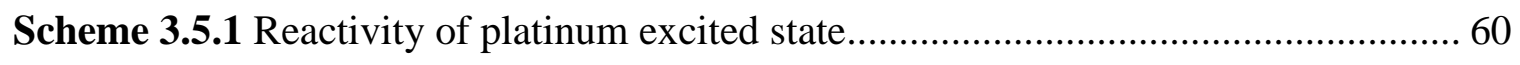




\title{
ABBREVIATIONS
}

\author{
$\mathbf{1}(\mathrm{Br}) \quad$ trans $-\mathrm{Pt}\left(\mathrm{PEt}_{3}\right)_{2}(\mathrm{Br})_{2}$ \\ $2(\mathrm{Br}) \quad$ trans $-\mathrm{Pt}\left(\mathrm{PEt}_{3}\right)_{2}(\mathrm{Br})_{4}$ \\ 1(cisBr $) \quad$ cis- $\mathrm{Pt}\left(\mathrm{PEt}_{3}\right)_{2}(\mathrm{Br})_{2}$ \\ $2(\operatorname{cisBr}) \quad$ cis- $\mathrm{Pt}\left(\mathrm{PEt}_{3}\right)_{2}(\mathrm{Br})_{4}$ \\ 1(depe) $\quad \operatorname{Pt}($ depe $)(\mathrm{Br})_{2}$ \\ 2(depe) $\quad \operatorname{Pt}($ depe $)(\mathrm{Br})_{4}$ \\ $\mathbf{1}(\mathrm{COD}) \quad \operatorname{Pt}(\mathrm{COD})(\mathrm{Br})_{2}$ \\ 1(Ph) trans- $\mathrm{Pt}\left(\mathrm{PEt}_{3}\right)_{2}(\mathrm{Br})(1-$ phenyl $)$ \\ 2(Ph) $\quad$ trans $-\mathrm{Pt}\left(\mathrm{PEt}_{3}\right)_{2}(\mathrm{Br})_{3}(1-$ phenyl $)$ \\ $\mathbf{1}\left(\mathrm{CF}_{3} \mathrm{Ph}\right) \quad$ trans $-\mathrm{Pt}\left(\mathrm{PEt}_{3}\right)_{2}(\mathrm{Br})(2$-(trifluoromethy)phenyl) \\ $2\left(\mathrm{CF}_{3} \mathrm{Ph}\right) \quad$ trans $-\mathrm{Pt}\left(\mathrm{PEt}_{3}\right)_{2}(\mathrm{Br})_{3}(2$-(trifluoromethy)phenyl) \\ $\mathbf{1}\left(\mathrm{MeO}_{2} \mathrm{Ph}\right) \quad$ trans-Pt( $\left.\mathrm{PEt}_{3}\right)_{2}(\mathrm{Br})$ (2,6-dimethoxyphenyl) \\ $\mathbf{1}\left(\mathrm{BrMeO}_{2} \mathrm{Ph}\right)$ trans-Pt $\left(\mathrm{PEt}_{3}\right)_{2}(\mathrm{Br})$ (3,5-dibromo-2,6-dimethoxyphenyl) \\ 2( $\left.\mathrm{BrMeO}_{2} \mathrm{Ph}\right)$ trans-Pt( $\left.\mathrm{PEt}_{3}\right)_{2}(\mathrm{Br})_{3}$ (3,5-dibromo-2,6-dimethoxyphenyl) \\ $\mathbf{1}(\mathrm{NPh}) \quad$ trans $-\mathrm{Pt}\left(\mathrm{PEt}_{3}\right)_{2}(\mathrm{Br})(2$-aminophenyl $)$ \\ 1(BrNPh) trans-Pt( $\left.\mathrm{PEt}_{3}\right)_{2}(\mathrm{Br})(3,5$-dibromo-2-aminophenyl) \\ 2(BrNPh) trans- $\mathrm{Pt}\left(\mathrm{PEt}_{3}\right)_{2}(\mathrm{Br})_{3}(3,5$-dibromo-2-aminophenyl $)$ \\ 1(iPrOPh) trans-Pt( $\left(\mathrm{PEt}_{3}\right)_{2}(\mathrm{Br})(2$-isopropoxylphenyl) \\ 1(BriPrOPh) trans-Pt $\left(\mathrm{PEt}_{3}\right)_{2}(\mathrm{Br})(5$-bromo-2-isopropoxyphenyl) \\ 2(BriPrOPh) trans- $\mathrm{Pt}\left(\mathrm{PEt}_{3}\right)_{2}(\mathrm{Br})_{3}$ (5-bromo-2-isopropoxyphenyl) \\ 1(1-Nap) trans-Pt $\left(\mathrm{PEt}_{3}\right)_{2}(\mathrm{Br})(1-$ naphthyl $)$
}




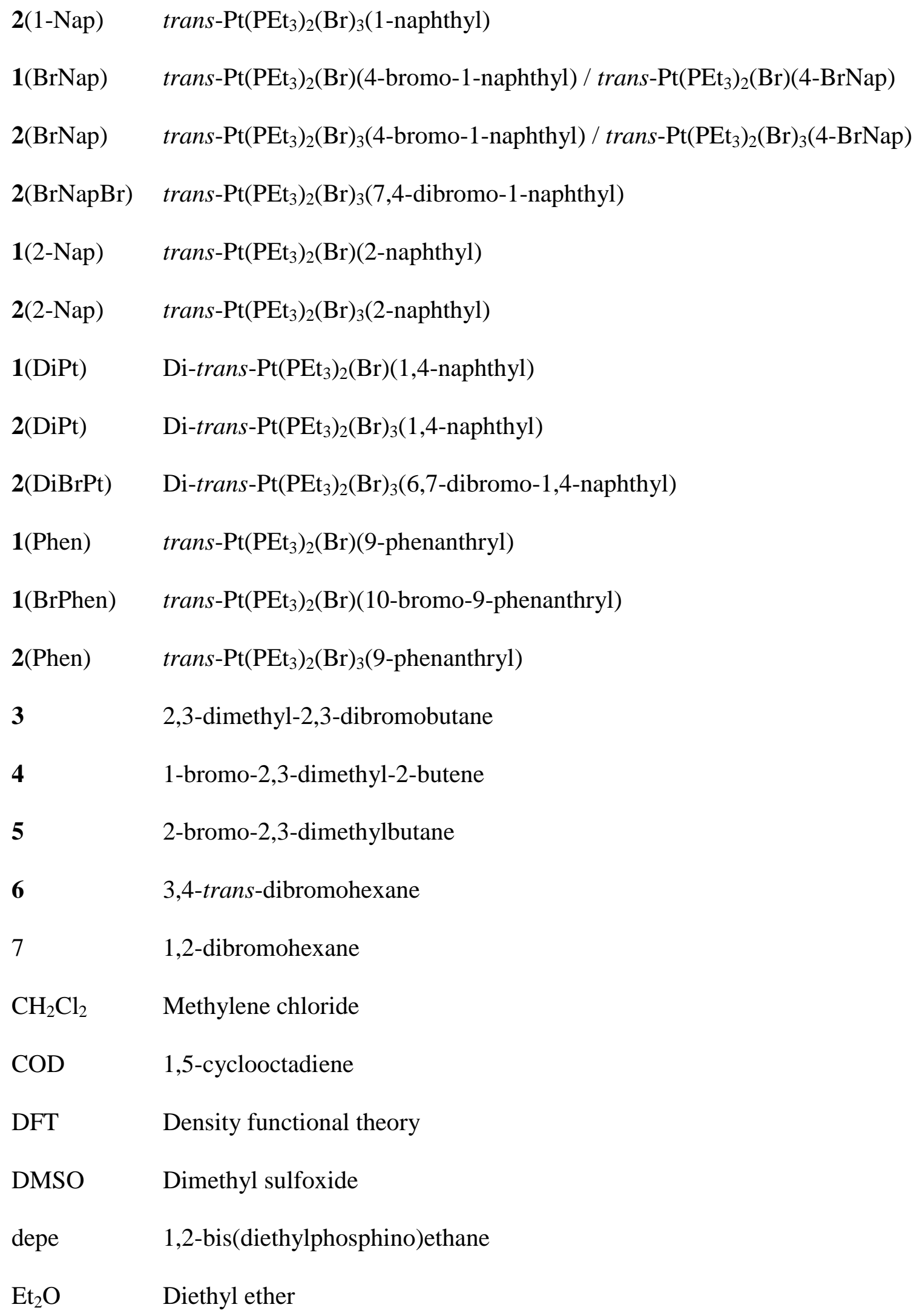




$\begin{array}{ll}\text { GC-MS } & \text { Gas chromatography-mass spectroscopy } \\ \mathrm{Hr} & \text { hours } \\ \text { LED } & \text { Light emitting diodes } \\ \text { MeTHF } & \text { 2-methyltetrahydrofuran } \\ \text { Min } & \text { minutes } \\ \text { PAC } & \text { Polycyclic aromatic carbon compounds } \\ \text { Ref } & \text { Reference } \\ \text { TME } & \text { 2,3-dimethyl-2-butene } \\ \text { THF } & \text { Tetrahydrofuran } \\ \text { Uv-vis } & \text { Ultraviolet-visible }\end{array}$




\section{LIST OF COMPLEXES}

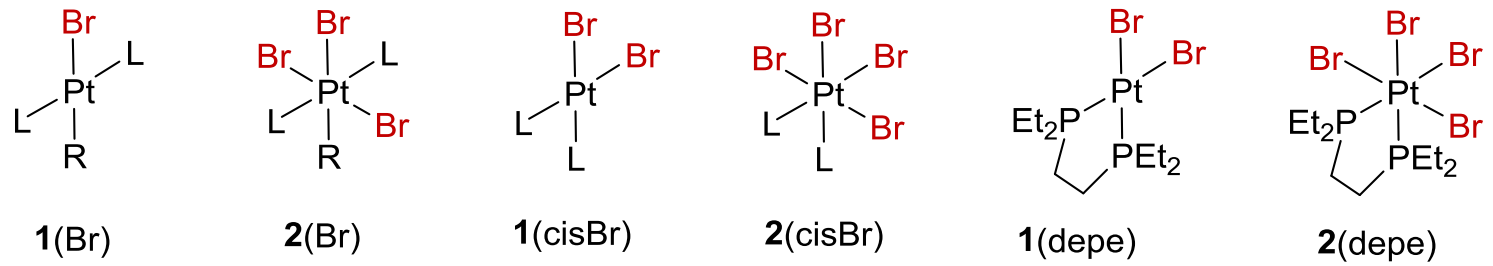<smiles>Br[P-](I)(I)c1ccccc1</smiles>

1(Ph)<smiles>BrP(Br)(Br)(I)c1ccccc1</smiles>

2(Ph)<smiles>Br[P](I)(I)c1cccc2ccccc12</smiles>

1(1-Nap)<smiles>Brc1ccc(P(Br)(I)(I)I)c2ccccc12</smiles>

1(BrNap)<smiles>Br[P-](Br)(Br)(I)(I)c1cccc2ccccc12</smiles>

2(1-Nap)<smiles>Brc1ccc([PH](Br)(Br)(Br)(I)I)c2ccccc12</smiles>

2(BrNap)<smiles>Brc1ccc2c(Br)ccc(P(Br)(Br)(I)I)c2c1</smiles>

2(BrNapBr)<smiles>Br[P](I)(I)c1ccc2ccccc2c1</smiles>

1(2-Nap)<smiles>BrP(Br)(Br)(I)c1ccc2ccccc2c1</smiles>

2(2-Nap)<smiles>Br[P-](I)(I)c1cc2ccccc2c2ccccc12</smiles>

1(Phen)<smiles>Brc1c(P(Br)(I)(I)I)c2ccccc2c2ccccc12</smiles>

1(BrPhen)<smiles>Br[P-](Br)(Br)(I)c1cc2ccccc2c2ccccc12</smiles>

2(Phen) 
<smiles>FC(F)(F)c1ccccc1P(I)(I)(I)I</smiles><smiles>FC(F)(F)c1ccccc1P(Br)(Br)(Br)I</smiles><smiles>Nc1ccccc1P(Br)(I)(I)I</smiles>
1( $\left.\mathrm{CF}_{3} \mathrm{Ph}\right)$ 2( $\left.\mathrm{CF}_{3} \mathrm{Ph}\right)$ 1(NPh)<smiles>Nc1c(Br)cc(Br)cc1P(Br)(Br)(Br)I</smiles><smiles>Nc1c(Br)cc(Br)cc1[P](Br)(I)I</smiles><smiles>COc1cccc(OC)c1P(Br)(I)(I)I</smiles>

$1\left(\mathrm{MeO}_{2} \mathrm{Ph}\right)$<smiles>COc1c(Br)cc(Br)c(OC)c1P(Br)(Br)(Br)I(Br)Br</smiles>

2( $\left.\mathrm{BrMeO}_{2} \mathrm{Ph}\right)$<smiles>COc1c(Br)cc(Br)c(OC)c1P(Br)(I)(I)I</smiles>

1( $\left.\mathrm{BrMeO}_{2} \mathrm{Ph}\right)$<smiles>CC(C)Oc1ccccc1P(Br)(I)(I)I</smiles>

1(iPrOPh)<smiles>CC(C)Oc1ccc(Br)cc1P(Br)(Br)(Br)I</smiles><smiles></smiles>

2(BriPrOPh)<smiles>Br[P](I)(I)c1ccc2ccccc2c1</smiles>

1(2-Nap)<smiles>BrP(Br)(Br)(I)c1ccc2ccccc2c1</smiles>

2(2-Nap)<smiles>[3H][P](I)(I)c1ccc([P](Br)(I)I)c2ccccc12</smiles>

1(DiPt)<smiles>BrP(Br)(I)(I)c1ccc([P-](Br)(Br)(Br)(I)I)c2ccccc12</smiles>

2(DiPt)<smiles>Br[P](Br)(I)c1ccc(P(Br)(I)(I)I)c2ccccc12</smiles>

1(DiPt)2<smiles>Brc1cc2c(P(Br)(Br)(Br)I)ccc(P(I)(I)(I)I)c2cc1Br</smiles>

2(DiBrPt) 


\title{
BROMINE PHOTOELIMINATION FROM ORGANOPLATINUM (IV) COMPLEXES
}

Alice Raphael Karikachery

Prof. Paul R. Sharp, Dissertation Supervisor

\begin{abstract}
With burgeoning population growth and widespread economic development world energy consumption is constantly on the rise. Currently most of our energy requirements are met through fossil fuels which are non-renewable. The production and use of these fuels also raise significant environmental concerns. Hence, renewable energy exploration is crucial to satiate the global energy demand and achieve sustainable growth.
\end{abstract}

Coupling solar energy conversion storage cycle with small molecule activation promises renewable and greener fuel technology. Hence, there has been great interest in photochemical water splitting for the production of hydrogen and oxygen. But the four electron oxidation of water is difficult and currently not very economical. Alternatively, light driven endergonic hydrogen halide (HX) splitting, a more facile two electron process is also being explored. Photolytic halide elimination from high valent late transition metal centers like platinum $(\mathrm{Pt})$, gold $(\mathrm{Au})$ and rhodium $(\mathrm{Rh})$ is a key step in designing HX splitting cycles. A high quantum yield $(\Phi)$ for the $\mathrm{X}_{2}$ photoelimination step is crucial for designing efficient transition metal based HX splitting cycles. Endergonic 
$\mathrm{X}_{2}$ photoelimination from transition metal complexes is rare and poorly understood though.

We have discovered $\mathrm{Br}_{2}$ photoelimination from $\sigma$-aryl platinum(IV) centers showing $\Phi$ as high as $82 \%$. Endothermic and endergonic $\mathrm{Br}_{2}$ elimination is observed with a radicallike excited state platinum precursor. Solution $\mathrm{Br}_{2}$ elimination is thermally reversible though and alkene traps are required. Insights and inferences gained from this research can be extended to understand the splitting of water and other small molecules using photon. Efficient and economical water splitting would be crucial for the realization of a hydrogen economy as well as providing us with clean energy in a sustainable fashion. 


\section{CHAPTER 1: INTRODUCTION}

\subsection{Solar energy and water splitting}

Global energy consumption will double by midcentury. ${ }^{1}$ Currently most of our energy requirements are fulfilled by fossil fuels. Higher energy efficiency and clean energy sources are imperative in reducing air pollution. ${ }^{2}$ Hence, it is essential to find renewable and carbon neutral energy sources for future generations. ${ }^{3}$ In recent years research interest has been burgeoning in exploring viable and economical technology to harness solar power. ${ }^{3-5}$ Solar energy as a power supply will not be available to societies if it cannot be stored. ${ }^{5,6}$ Storing the sun's abundant energy that falls on earth in chemical bonds by designing solar driven molecular machines to split water into hydrogen and oxygen would be key to a hydrogen economy. ${ }^{7}$ Hydrogen can be directly used or can be combined with carbon dioxide to generate methanol, a liquid fuel. ${ }^{8}$ It is clean, abundant and a zero-emission fuel. Hydrogen economy is crucial for securing our energy future. In fuel cells hydrogen combines with oxygen to form water and produce electrical or thermal energy. Production, storage, transportation and usage impediments have to be overcome before the realization of hydrogen economy cost effectively. ${ }^{9}$

\subsection{Hydrogen halide splitting}

Solar energy conversion storage cycle coupling with small molecule activation promises renewable and greener fuel technology. Hence, there has been great interest in photochemical water splitting for the production of hydrogen and oxygen. Water splitting 
to $\mathrm{H}_{2}$ and $\mathrm{O}_{2}$ is neither facile nor economical currently. It is difficult and a complex fourelectron four-proton process. Comparatively, hydrogen halide ( $\mathrm{HX}: \mathrm{HCl}$ and $\mathrm{HBr}$ ) splitting is a relatively easier two-electron two-proton process. Understanding a simpler proton-coupled electron transformation can expand our knowledge of multi-electron processes with regards to electron and proton management. Overall, energy stored per electron in $\mathrm{HX}$ splitting is comparable to $\mathrm{H}_{2} \mathrm{O}$ splitting. Further, the chemical energy can be recovered in a fuel cell as electricity. $\mathrm{H}_{2} / \mathrm{X}_{2}$ fuel cell literature is extensive and offers many advantages. ${ }^{10}$ Fuel cell efficiency for cells using $\mathrm{H}_{2} / \mathrm{O}_{2}, \mathrm{H}_{2} / \mathrm{Cl}_{2}$ and $\mathrm{H}_{2} / \mathrm{Br}_{2}$ are $50 \%^{11}, 70 \%^{12}$ and $90 \%^{13}$, respectively. Hence, exploring organoplatinum(IV) photocatalysts for $\mathrm{HBr}$ splitting is very relevant. The overall reactions and energetics for $\mathrm{H}_{2} \mathrm{O}$ and $\mathrm{HX}$ splitting are shown in Equations 1.2 .1 to 1.2 .3 . $^{14}, 15$

$$
\begin{aligned}
2 \mathrm{H}_{2} \mathrm{O}_{(\mathrm{l})} & \rightarrow 2 \mathrm{H}_{2(\mathrm{~g})}+\mathrm{O}_{2(\mathrm{~g})} \quad \Delta \mathrm{G}^{\mathrm{o}}=237.2 \mathrm{kJmol}^{-1}, \mathrm{E}^{\mathrm{o}}=-1.23 \mathrm{~V} \\
2 \mathrm{HCl}_{(\mathrm{g})} & \rightarrow \mathrm{H}_{2(\mathrm{~g})}+\mathrm{Cl}_{2(\mathrm{~g})} \quad \Delta \mathrm{G}^{\mathrm{o}}=131.2 \mathrm{kJmol}^{-1}, \mathrm{E}^{\mathrm{o}}=-1.36 \mathrm{~V} \\
2 \mathrm{HBr}_{(\mathrm{g})} & \rightarrow \mathrm{H}_{2(\mathrm{~g})}+\mathrm{Br}_{2(\mathrm{l})} \quad \Delta \mathrm{G}^{\mathrm{o}}=103.2 \mathrm{kJmol}^{-1}, \mathrm{E}^{\mathrm{o}}=-1.06 \mathrm{~V}
\end{aligned}
$$

\subsection{Metal catalysts for $\mathrm{HX}$ splitting}

Photolytic reductive halogen elimination from metal centers is significant because they can be utilized in solar energy conversion storage cycle. The photocatalytic HX splitting

cycle involving a metal complex is shown in Scheme 1.3.1. ${ }^{16,17}$ The metal complex is a 
photocatalyst. By absorption of light $\mathrm{L}_{\mathrm{n}} \mathrm{M} \mathrm{X}_{2}$ reductively photoeliminates $\mathrm{X}_{2}$ to form $\mathrm{L}_{\mathrm{n}} \mathrm{M}$. The metal center is reduced and its oxidation state changes from a high-valent to a low-valent one. Photochemically generated $\mathrm{X}_{2}$ should be removed soon as it is formed to prevent back reaction and reactions with catalytic intermediates as well. This removal can be achieved through experimental design or by using traps (solvent or alkenes). ${ }^{18-20}$ Energy storage is eliminated by the use of $\mathrm{X}_{2}$ traps though. By increasing the quantum efficiency of the $\mathrm{X}_{2}$ photoproduction step maximum storage of energy can be achieved in the absence of traps. ${ }^{21}$ Oxidative addition of $\mathrm{HX}$ to $\mathrm{L}_{\mathrm{n}} \mathrm{M}$ leads to the formation of the hydrido-halide $\mathrm{L}_{\mathrm{n}} \mathrm{MHX}$ intermediate. With the introduction of the second HX molecule there is $\mathrm{H}_{2}$ production and overall oxidative addition of $\mathrm{X}_{2}$ to the metal center.

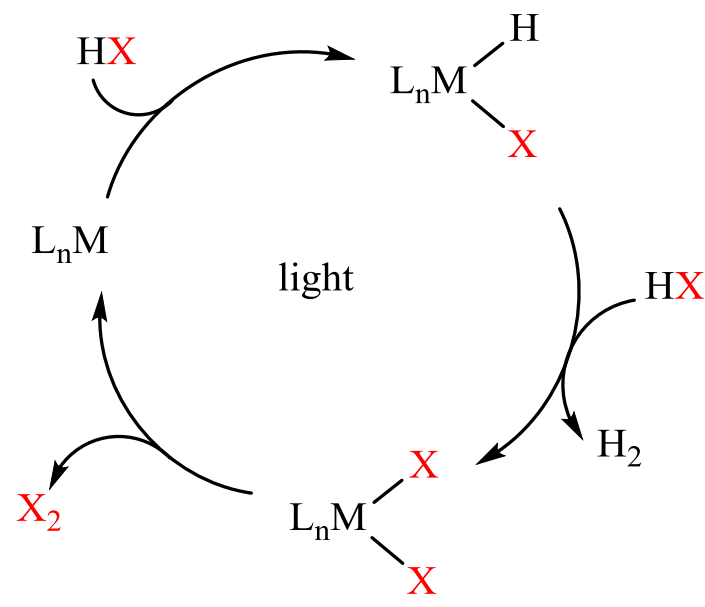

Scheme 1.3.1. Photocatalytic HX splitting cycle for a monometallic catalyst. ${ }^{16,17,22}$

The HX splitting cycle for a bimetallic system is shown in Scheme 1.3.2. The oxidation and reduction half reactions are decoupled at two different metal centers. Depending on 
the metal center electron richness, the hydrogen production step can happen photochemically or through an acid-base pathway from $\mathrm{L}_{\mathrm{n}} \mathrm{MHX} .{ }^{17}$ Hence, photolytic reductive halogen elimination from metal center is significant and can be utilized in solar energy conversion storage cycle.

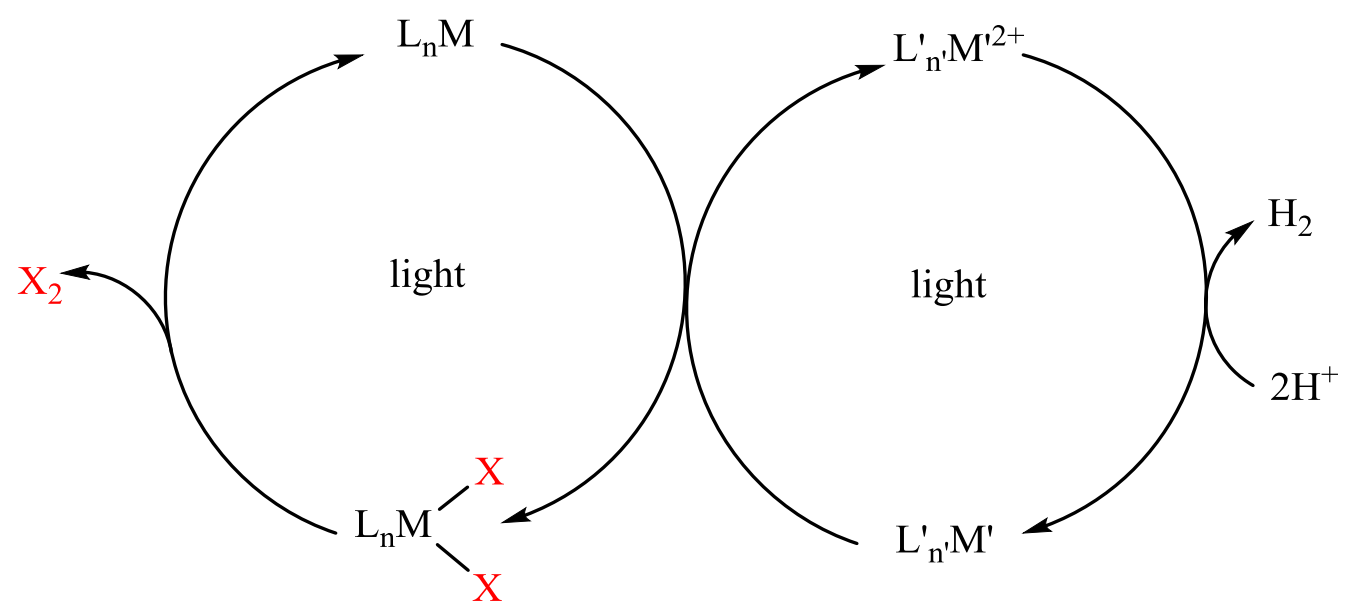

Scheme 1.3.2. Photocatalytic HX splitting cycle for a bimetallic catalyst. ${ }^{23}$

For HX splitting, heterogeneous photocatalysis is advantageous from a feasibility and engineering perspective. ${ }^{24}$ By exploring homogenous photocatalytic systems we can gain mechanistic insights and knowledge about molecular transformations. Also, tunability of steric and electronic factors in homogenous compounds is very helpful in studying these complexes. $^{17}$ 


\subsection{Homogenous catalysis and functionalization of PAC}

Previously the Sharp group has been extensively investigating homogenous catalysis and functionalization of polycyclic aromatic carbon compounds (PAC). Our group had reported the very first platinaoxetane complex from the coupling reaction of an alkene and a metal oxo complex. ${ }^{25}$ Also mechanistic probing of the reactions of platinum oxo and hydroxo complexes with alkenes helped in understanding the Wacker process. ${ }^{26,27}$ Organometallic chemistry of $\sigma$-bonded PAC to late transition metals (especially the $\mathrm{Ni}$ triad) has led to novel synthetic precursors. Bond expansion on the edge of the PAC paves way for synthesis of fullerenes, nanotubes and related fragments which have diverse applications in electronics and catalysis for the modern world. ${ }^{28}$

Whilst investigating the possibility of synthesizing novel halogenated PACs from corranulenyl, phenanthrenyl and naphthalenyl organoplatinum(IV) complexes, Dr. Han Baek Lee, a former group member, discovered facile room light-induced ring bromination of the PAC aryl C-H bond as shown in Scheme1.4.1. 

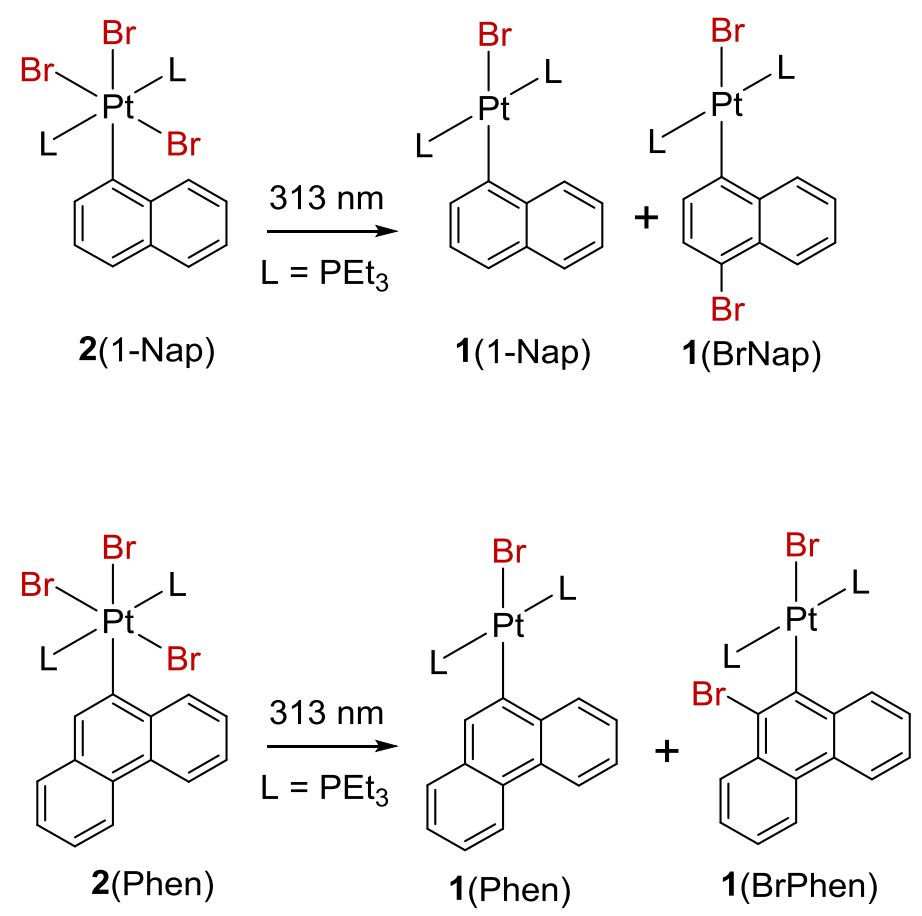

Scheme 1.4.1. Photolysis of 2(1-Nap) and 2(Phen).

Moreover, photolysis in solvents with weak C-H (low bond dissociation energy) bonds like triphenylmethane and dihydroanthracene, led to 1(1-Nap), the non-ring brominated platinum(II) analogue along with the ring brominated $\mathbf{1}(\mathrm{BrNap})$ complex. $\mathrm{HBr}$ was also detected. The same result was observed in the case of the phenanthrenyl platinum (IV) complex, as shown in Table 1.4.1. Initially, these results were significant with regards to potential transition metal catalyzed photolytic halogenation of PACs, since conventional methods are tedious and non-selective. ${ }^{29}$ This steered our group towards exploring photoelimination of $\mathrm{Br}_{2}$ and $\mathrm{Cl}_{2}$ from organoplatinum(IV) complexes. ${ }^{29}$ Moreover, steric and electronic changes were easily achievable in these systems by changing the $\sigma$-bonded 
PAC or phosphine ligands. Also, molecular transformations and reaction progress were easier to track using ${ }^{31} \mathrm{P}$ NMR spectroscopy.

Table 1.4.1. Photolysis product yields for 2(1-Nap) and 2(Phen) in toluene and with added bromine traps. ${ }^{29,30}$

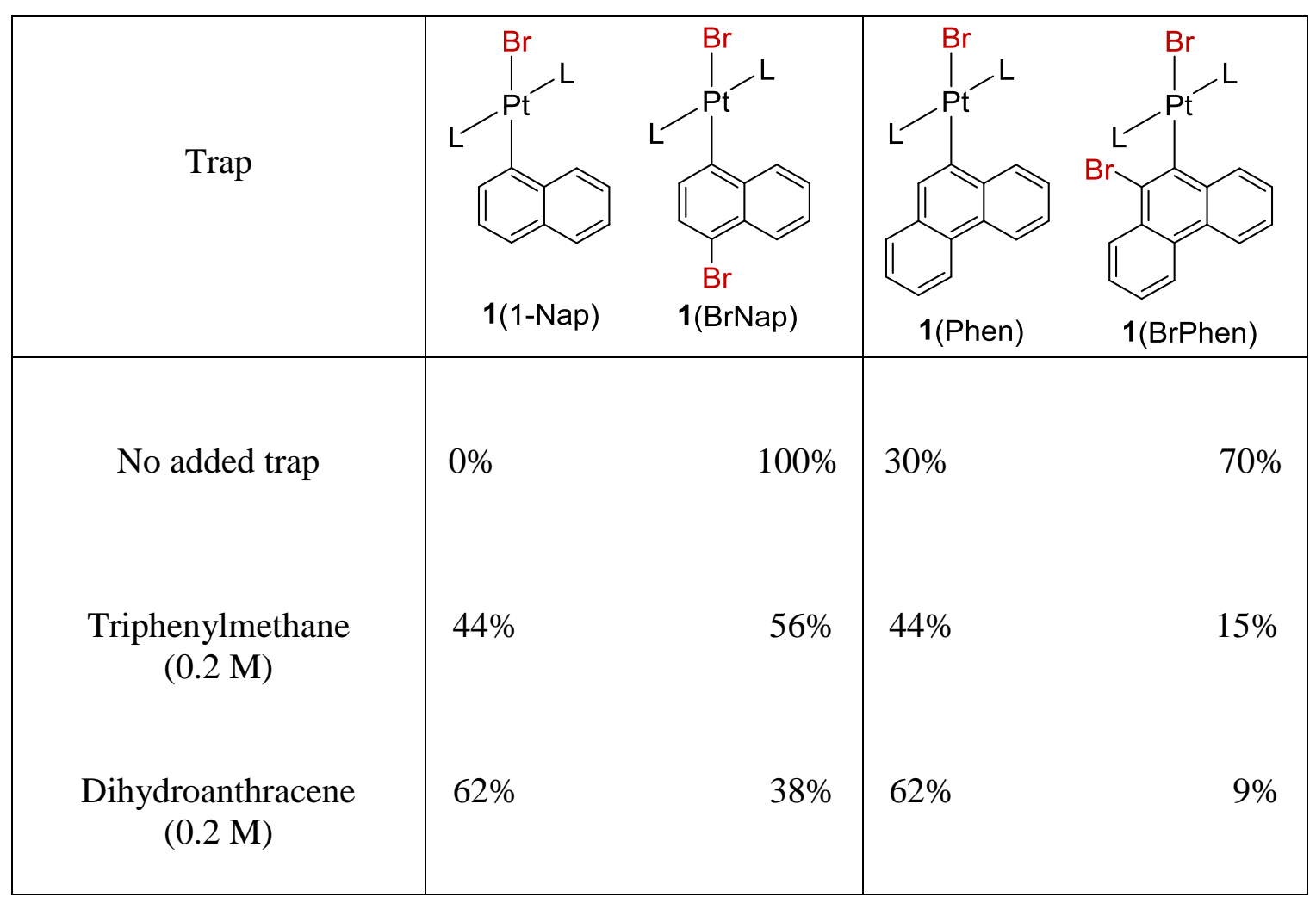

\subsection{Halogen elimination literature review}

Halogen elimination from metal centers is not so common. ${ }^{21}$ Solution state photoelimination usually happens in the presence of halogen traps like alkenes. ${ }^{20,31}$ Photoeliminated $\mathrm{Cl}_{2}$ or $\mathrm{Br}_{2}$ can add back to the metal center. The trap prevents the facile 
back reaction. In the last decade, Nocera and coworkers have synthesized various rhodium, iridium, nickel, platinum and gold monometallic and bimetallic mixed-valent as well as uni-valent complexes for photolytic $\mathrm{Br}_{2}$ and $\mathrm{Cl}_{2}$ elimination. ${ }^{17,20,31-33}$ The metal d-electron count varied from $\mathrm{d}^{7}$ to $\mathrm{d}^{10}$ in these complexes. A bimetallic $\mathrm{Pt}_{2}\left(\mathrm{tfepma}_{2} \mathrm{Cl}_{6}\right.$ $($ tfepma $=$ bis(trifluoroethoxylphosphino)methylamine) complex showing $38 \%$ quantum yield (in the solution state) and trap free $\mathrm{Cl}_{2}$ elimination in the solid state was reported as depicted in Scheme 1.5.1. ${ }^{32}$
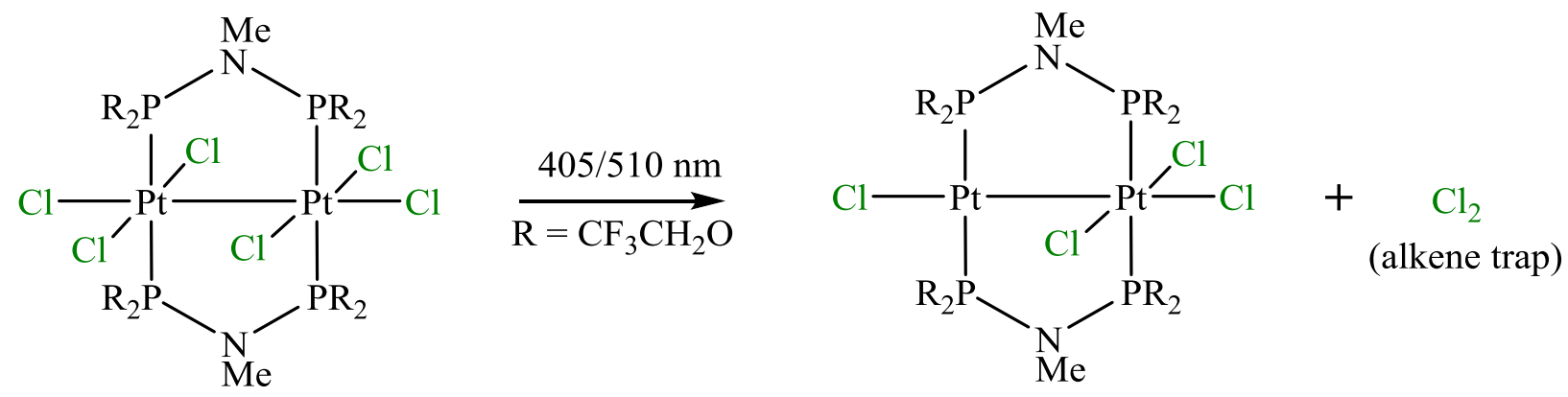

Scheme 1.5.1. Bimetallic platinum complex.

Dinuclear and mononuclear $\mathrm{Au}(\mathrm{III})$ complexes showing $\mathrm{Cl}_{2}$ and $\mathrm{Br}_{2}$ elimination with quantum yields varying from 10 to $25 \%$ were also reported as shown in Scheme 1.5.2. ${ }^{21}$ These gold complexes were not thermally stable. Thermal halogen elimination at room temperature in the presence of alkene trap was seen. 


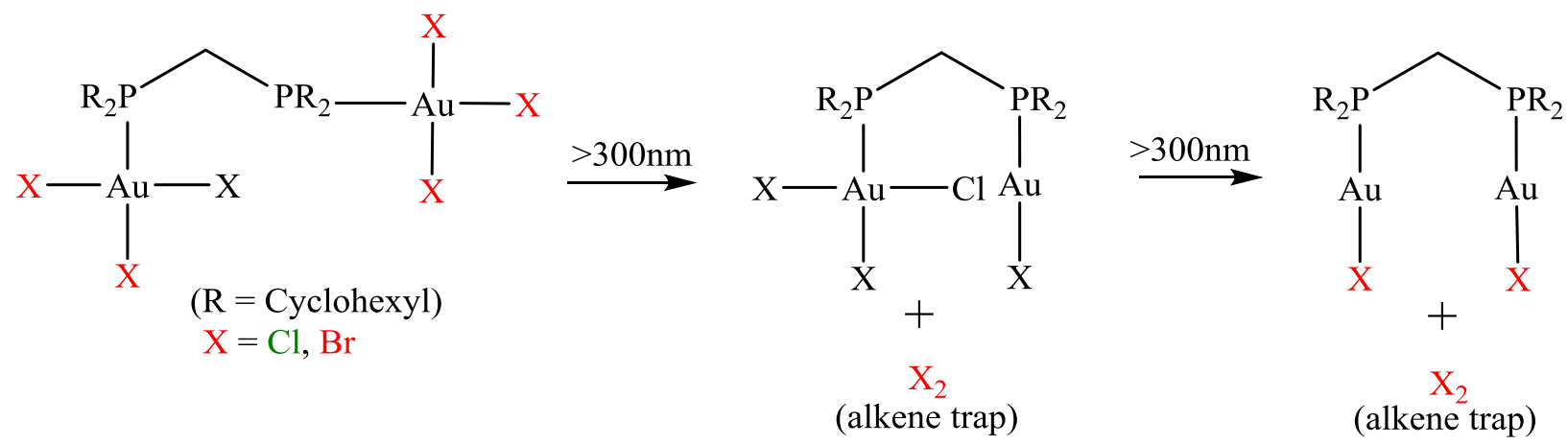

Scheme 1.5.2. Bimetallic gold complex.

However, $\mathrm{Cl}_{2}$ and $\mathrm{Br}_{2}$ photoelimination yields for these complexes were not reported. Moreover solid state photoeliminated $\mathrm{Cl}_{2}$ was detected by mass spectroscopy only. Mass spectroscopy can detect very small amounts of $\mathrm{Cl}_{2}$. The Gabbai group has also been studying the dinuclear tellurium platinum $(\mathrm{TePt})$ core for photoreductive elimination of $\mathrm{Cl}_{2}$ as shown in Scheme 1.5.3. ${ }^{34}$ They report a low $4 \%$ quantum yield and $\mathrm{Cl}_{2}$ trap products based on GC-MS only.
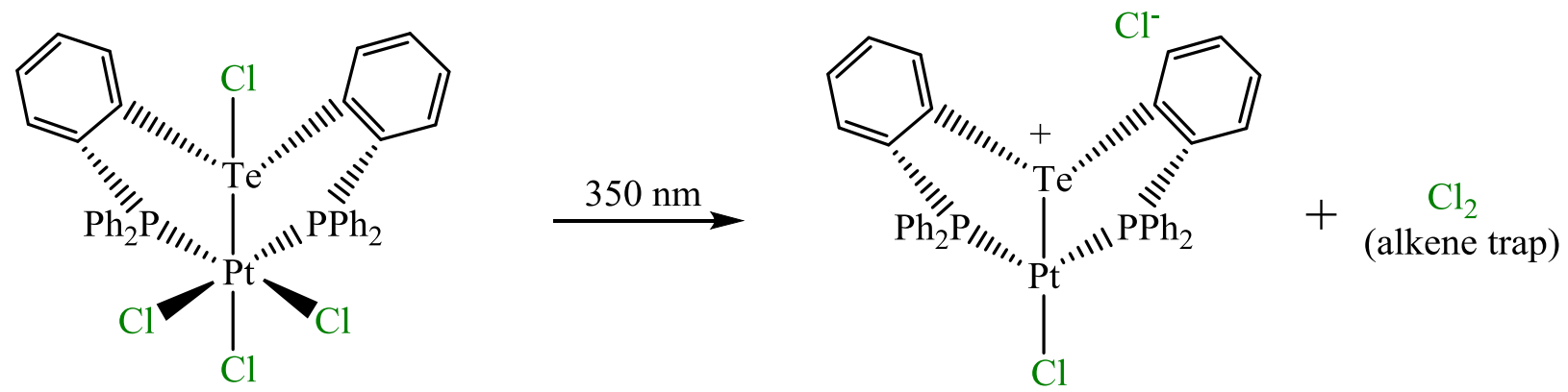

Scheme 1.5.3. Dinuclear tellurium platinum complex. 
Since in the literature there are fewer examples of complexes showing facile visible light induced halogen elimination more research is needed. Mechanistic understanding of halogen elimination from metal centers with regards to HX splitting is crucial for the design of photocatalysts. ${ }^{22,} 30$ Eventually insights from homogenous catalysis can be extended to heterogeneous trap-free catalysis for HX splitting. Hence our group's recent focus has been understanding halogen $\left(\mathrm{Br}_{2}, \mathrm{Cl}_{2}\right), \mathrm{HOCl}$ and $\mathrm{H}_{2} \mathrm{O}_{3}$ photoeliminations from platinum and iridium centers. ${ }^{30,35-38}$

\subsection{Research summary}

We have discovered $\mathrm{Br}_{2}$ photoelimination from $\sigma$-aryl platinum(IV) centers showing quantum yield as high as $82 \%$. Synthesis, characterization and photolytic $\mathrm{Br}_{2}$ elimination studies on a variety of phenyl, napthyl and phenanthryl organoplatinum(IV) complexes were undertaken. Chelated and cis phosphine ligand modifications were also explored in our platinum(IV) complexes. Easy tunability of the ligand framework was crucial in designing platinum(IV) complexes with varied steric and electronic aspects. Solution state $\mathrm{Br}_{2}$ photoelimination experiments were carried out in the presence of alkene traps. Solution $\mathrm{Br}_{2}$ elimination is thermally reversible in the absence of traps. ${ }^{31} \mathrm{P}$ NMR spectroscopy was an excellent tool in monitoring reductive elimination of $\mathrm{Br}_{2}$ from $\operatorname{Pt}(\mathrm{IV})$ centers. Quantum yield measurements were undertaken to quantify the efficiency of photolytic $\mathrm{Br}_{2}$ elimination. Alkene product profile and their respective yields were investigated. 2,3-dimethy-2-butene (TME), a reactive trap showed radical pathway products. Reaction with cis-2-hexene, a less reactive and unsymmetrical trap, showed exclusive $\mathrm{Br}_{2}$ anti-addition product. Evidence for molecular bromine $\left(\mathrm{Br}_{2}\right)$ as the 
brominating agent was also found in a competition experiment with mixed alkene (trans3-hexene and 1-hexene) as traps. 1-hexene $\mathrm{Br}_{2}$ addition versus platinum(II) $\mathrm{Br}_{2}$ addition rates were estimated. Calorimetric measurements by Prof. Carl D. Hoff's group and DFT calculations by Prof. Paul R. Sharp shows endothermic and endergonic $\mathrm{Br}_{2}$ elimination with a radical-like excited state platinum precursor. 


\section{CHAPTER 2: BROMINE PHOTOELIMINATION FROM PLATINUM(IV) COMPLEXES}

\subsection{Background}

Net $\mathrm{Br}_{2}$ photoelimination was observed in our family of platinum(IV) bromo complexes in the solution state in the presence of traps (alkenes). Most of these compounds contain $\sigma$-bonded aryl mononuclear organoplatinum(IV) centers with phosphine and bromo ligands. Some complexes studied were exclusively phosphine and bromo ligand coordination frameworks only. A bimetallic diplatinum naphthalene system was also investigated. In comparison to existing literature, our systems showed very high quantum efficiency for $\mathrm{Br}_{2}$ photoelimination. A quantum yield of $82 \%$ was measured for one of our complexes. ${ }^{30}$ The work was supported by DFT calculations by Prof. Sharp and calorimetric measurements by Prof. Hoff's group. These results show that the $\mathrm{Br}_{2}$

elimination process is endergonic (energy consuming) with energy storage varying from $2 \mathrm{kcal} / \mathrm{mol}$ to $22 \mathrm{kcal} / \mathrm{mol}$. Bromine trapping experiments and kinetic studies show evidence for $\mathrm{Br}_{2}$ elimination as shown in Equation 2.1.2. But with highly reactive trap like TME, a radical reaction product profile is also observed. This result suggests direct reaction of the trap with the radical character platinum excited state before molecular bromine elimination. 


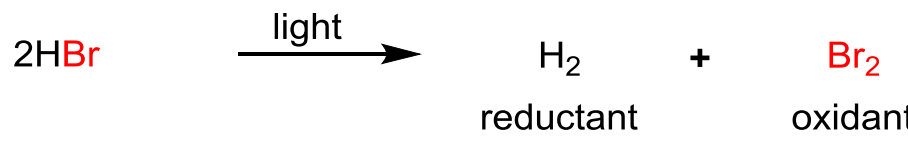

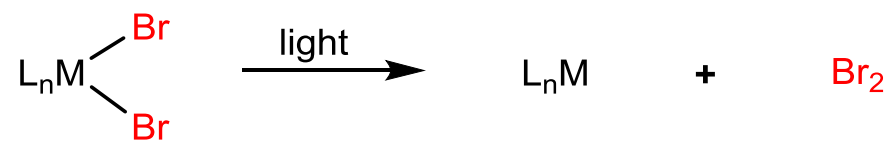

\subsection{Synthesis and characterization}<smiles>FC(F)(F)c1ccccc1P(Br)(I)(I)I</smiles>

$1\left(\mathrm{CF}_{3} \mathrm{Ph}\right)$<smiles>FC(F)(F)c1ccccc1P(Br)(Br)(Br)I</smiles>

$\mathbf{2}\left(\mathrm{CF}_{3} \mathrm{Ph}\right)$<smiles>Nc1ccccc1P(Br)(I)(I)I</smiles>

1(NPh)<smiles>Nc1c(Br)cc(Br)cc1[P+](Br)(Br)(Br)(Br)I</smiles><smiles>COc1c(Br)cc(Br)c(OC)c1P(Br)(I)(I)I</smiles>

1( $\left(\mathrm{BrMeO}_{2} \mathrm{Ph}\right)$<smiles>Nc1c(Br)cc(Br)cc1[P](Br)(I)I</smiles><smiles>COc1cccc(OC)c1P(Br)(I)(I)I</smiles><smiles>COc1c(Br)cc(Br)c(OC)c1P(Br)(Br)(Br)Br</smiles>

2( $\left(\mathrm{BrMeO}_{2} \mathrm{Ph}\right)$<smiles>CC(C)Oc1ccccc1P(Br)(I)(I)I</smiles>

1(iPrOPh)<smiles>CC(C)Oc1ccc(Br)cc1P(Br)(Br)(Br)I</smiles>

2(BriPrOPh)<smiles></smiles>

1(BriPrOPh)<smiles>Br[P](I)(I)c1ccc2ccccc2c1</smiles>

1(2-Nap)<smiles>BrP(Br)(Br)(I)c1ccc2ccccc2c1</smiles>

2(2-Nap)

Scheme 2.2.1. Ortho-substituted phenyl and 2-naphthyl platinum(II) and platinum(IV) complexes. 
Platinum(II) and platinum(IV) complexes shown in Scheme 2.2.1. were synthesized and characterized. These ortho-substituted phenyl and 2-naphthyl complexes were prepared to understand the effect of sterics in $\mathrm{Br}_{2}$ photoelimination from platinum(IV) complexes.

By oxidative addition of the corresponding aryl halide to the tetrakis(triethylphosphine) platinum(0) complex $\left(\mathrm{Pt}\left(\mathrm{PEt}_{3}\right)_{4}\right)$, platinum(II) complexes were prepared as shown in Scheme 2.2.2..$^{29,30,39}$
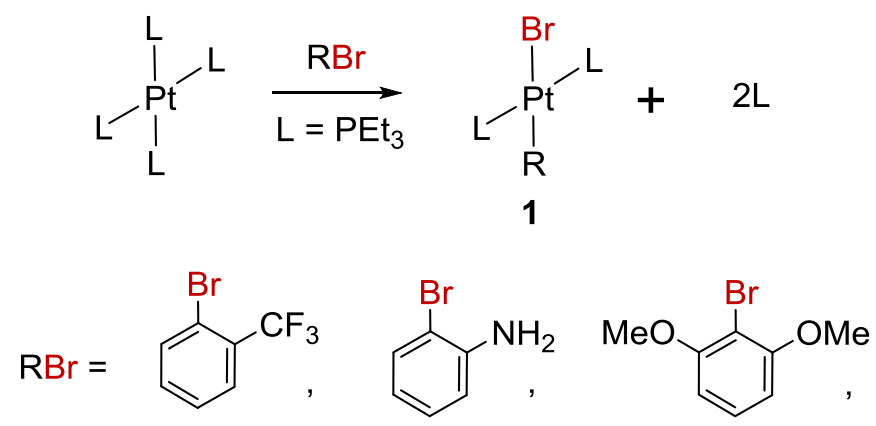<smiles>CC(C)Oc1ccccc1Br</smiles>

Scheme 2.2.2. Synthesis of substituted phenyl and 2-naphthyl platinum(II) complexes.

Most of our platinum(IV) (2) complexes were synthesized by direct bromination of the platinum(II) (1) complexes, as shown in Scheme 2.2.3. These bromination reaction rates were extremely fast. One of our group members Lasantha Wickramasinghe monitored the kinetics of $\mathrm{Br}_{2}$ addition to platinum(II) using low temperature $\mathrm{NMR}$ in $\mathrm{CH}_{2} \mathrm{Cl}_{2}$ and 
toluene. The rate of $\mathrm{Br}_{2}$ oxidative addition to the platinum(II) center was faster than the NMR time scale.
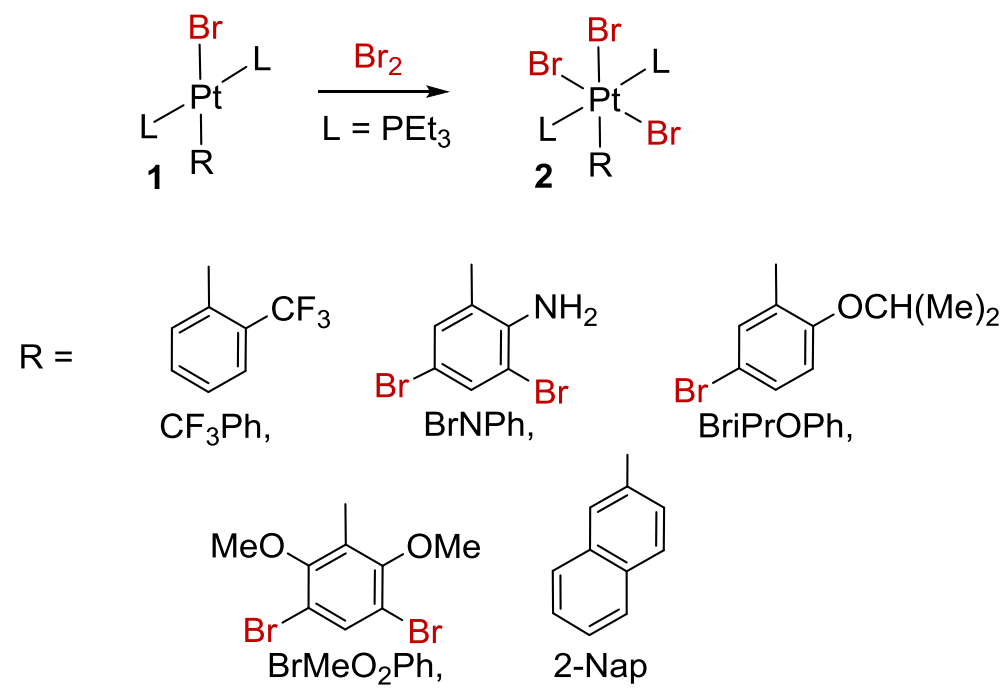

Scheme 2.2.3. Synthesis of ortho-substituted phenyl and 2-naphthyl platinum(IV) complexes.

Subsequent to $\mathrm{Br}_{2}$ addition to the metal center aryl ring bromination is observed. Thus, $\sigma$ aryl ring brominated platinum complexes $2(\mathrm{BrNPh}), \mathbf{2}\left(\mathrm{BrMeO}_{2} \mathrm{Ph}\right)$ and $\mathbf{2}(\mathrm{BriPrOPh})$ were isolated. $\mathrm{Br}_{2}$ photoelimination yields the corresponding $\mathbf{1}(\mathrm{BrNPh}), \mathbf{1}\left(\mathrm{BrMeO}_{2} \mathrm{Ph}\right)$ and $\mathbf{1}(\mathrm{BriPrOPh})$ platinum(II) complexes respectively. We observed that with electrondonating substituents such as $-\mathrm{OCH}_{3},-\mathrm{OCH}(\mathrm{Me})_{2}$ and $-\mathrm{NH}_{2}$ on the aryl ring, electrophilic bromine attack on the ring is favored. However, with an electron-withdrawing substituent such as $-\mathrm{CF}_{3}$ no ring brominated $2\left(\mathrm{CF}_{3} \mathrm{Ph}\right)$ products are observed. This observation is consistent with the electrophilic attack of aromatic ring systems discussed in general chemistry textbooks. ${ }^{40}$ 
The phenyl, naphthyl and phenanthryl platinum(II) and platinum(IV) complexes shown in Scheme 2.2.4 were previously synthesized by Dr. Han Baek Lee. ${ }^{29} \mathrm{Br}_{2}$ photoelimination studies, calorimetry, molar extinction coefficient and quantum yield measurements were further carried out for these complexes.<smiles>Br[Pb](I)(I)c1ccccc1</smiles>

1(Ph)<smiles>Brc1ccc(P(Br)(Br)(I)I)c2ccccc12</smiles>

2(BrNap)<smiles>Br[Te](Br)(Br)(I)(I)c1ccccc1</smiles>

2(Ph)<smiles>Br[Pb](I)(I)c1cccc2ccccc12</smiles>

1(1-Nap)<smiles>Brc1ccc([Pb](I)(I)I)c2ccccc12</smiles>

1(BrNap)<smiles>Br[P-](Br)(Br)(I)(I)c1cccc2ccccc12</smiles>

2(1-Nap)<smiles>Br[P](I)(I)c1cc2ccccc2c2ccccc12</smiles>

1(Phen)<smiles>Brc1c(P(Br)(I)(I)I)c2ccccc2c2ccccc12</smiles>

1(BrPhen)<smiles>Br[P-](Br)(Br)(I)c1cc2ccccc2c2ccccc12</smiles>

2(Phen)

Scheme 2.2.4. Phenyl, naphthyl and phenanthryl Pt(II) and Pt(IV) complexes.

1(BrNap) and 2(BrNap) were also synthesized by an alternative route using 1,4dibromonaphthalene as shown in Scheme 2.2.5. ${ }^{30}$ The ligand 1,4-dibromonapthalene was synthesized from a procedure reported by Cakmak et al. ${ }^{41}$ 
<smiles>Brc1ccc(Br)c2ccccc12</smiles>

$+\quad \mathrm{Pt}(\mathrm{L})_{4}$

$$
\overrightarrow{\mathrm{L}=\mathrm{PEt}_{3}}
$$<smiles>Br[P](I)(I)c1ccc(I)c2ccccc12</smiles>

1(BrNap)<smiles></smiles>

1(BrNap)
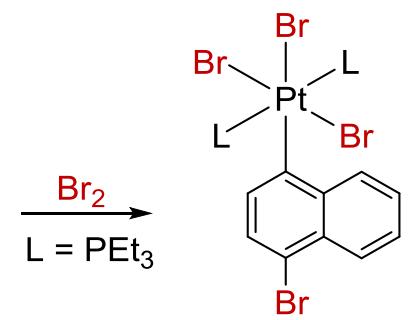

2(BrNap)

Scheme 2.2.5. Synthesis of $\mathbf{1}(\mathrm{BrNap})$ and $\mathbf{2}$ (BrNap).

Bimetallic platinum complexes were also prepared. The $\mathbf{1}(\mathrm{DiPt})$ complex was prepared by using a 2:1 ratio of $\mathrm{Pt}\left(\mathrm{PEt}_{3}\right)_{4}$ versus 1,4-dibromonaphthalene. Further, addition of two equivalence $\mathrm{Br}_{2}$ gave the bimetallic platinum(IV) complex 2(DiPt) as shown in Scheme 2.2.6. 


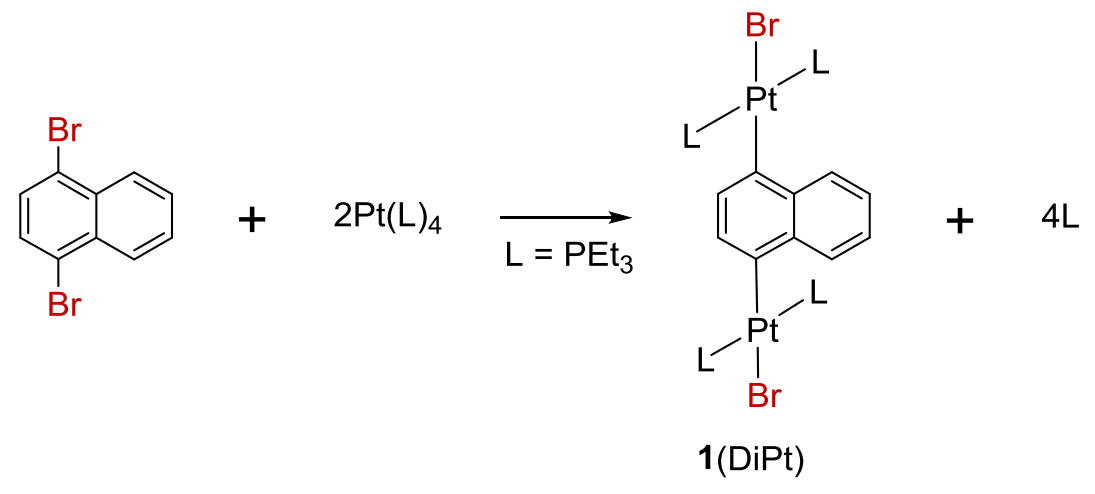

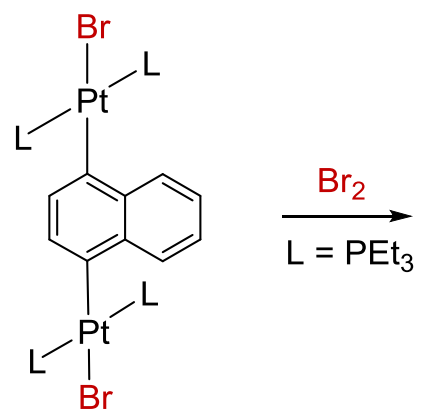

1(DiPt)

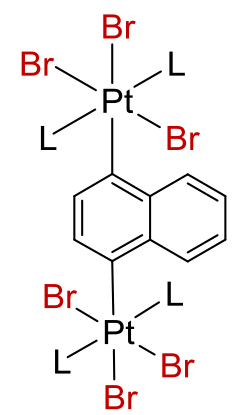

2(DiPt)

Scheme 2.2.6. Synthesis of diplatinum complexes.

Photoelimination of $\mathrm{Br}_{2}$ was investigated from platinum(IV) complexes 2(Br), 2(cisBr) and 2(depe) containing no aryl ligand. The complexes are shown in Scheme 2.2.7. These complexes have been reported previously. $\mathrm{Br}_{2}$ photoelimination with alkene trap was studied. 
<smiles>[R][Pb]([3H])(Cl)Br</smiles>

$1(\mathrm{Br})$<smiles></smiles>

2(Br)<smiles>Br[Pb](Br)(I)I</smiles>

$1(\mathrm{cisBr})$<smiles>Br[IH](Br)(Br)Br</smiles>

2(cisBr)<smiles>CCP1CCCP1(Br)(Br)Br</smiles>

1(depe)

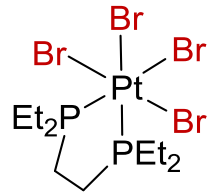

2(depe)

Scheme 2.2.7. Platinum(II) and platinum(IV) phosphine complexes.

Addition of $\mathrm{Br}_{2}$ to $\mathbf{1}(\mathrm{Br})$ yields $2(\mathrm{Br})$ as shown in Scheme 2.2.8. Calorimetry, molar extinction coefficient and quantum yield measurements were further carried out for $2(\mathrm{Br})$.

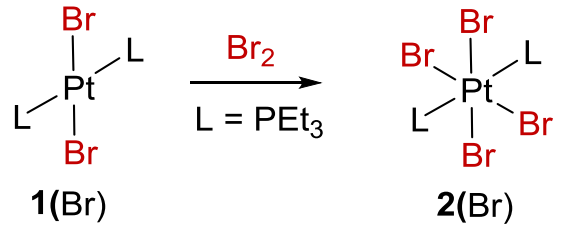

Scheme 2.2.8. trans-phosphine platinum(IV) complex.

$\mathbf{2}(\mathrm{cisBr})$ was obtained by bromination of $\mathbf{1}(\mathrm{cisBr})$ as shown in Scheme 2.2.9. 2(cisBr) left in solution, over the course of a day isomerizes to $\mathbf{2}(\mathrm{Br})$. Correspondingly, $2(\mathrm{Br})$ solutions do not show isomerization to $\mathbf{2}(\mathrm{cisBr})$ and are relatively stable. 


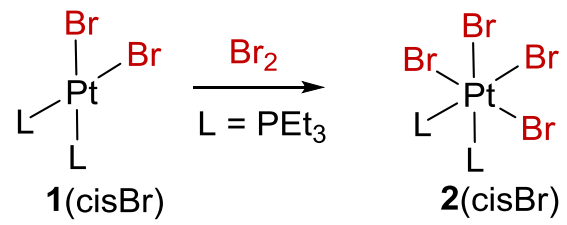

Scheme 2.2.9. cis-phosphine platinum(IV) complex.

Chelated phosphine platinum(II) complex 2(depe) was synthesized through an alternative route. Addition of 1,2-bis(diethylphosphino)ethane (depe) to $\mathrm{Pt}(\mathrm{COD})(\mathrm{Cl})_{2}{ }^{42}$ yielded $\mathrm{Pt}($ depe $)(\mathrm{Cl})_{2}$ through ligand exchange. 1(depe) was then obtained from metathesis of $\mathrm{Pt}($ depe $)(\mathrm{Cl})_{2}$ using $\mathrm{KBr}$. Bromination of $\mathbf{1}$ (depe) yielded 2(depe) as shown in Scheme 2.2.10. The 2(depe) complex has poor solubility in $\mathrm{CDCl}_{3}$ and $\mathrm{CH}_{2} \mathrm{Cl}_{2}$. Hence photolysis was carried out in DMSO in which solubility was slightly better.

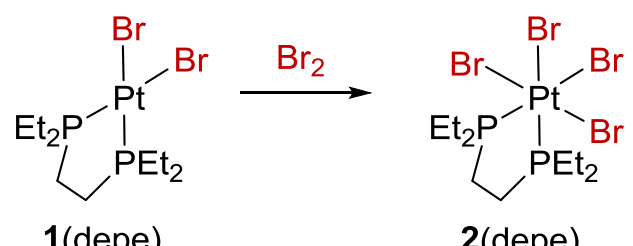

Scheme 2.2.10. Chelated phosphine platinum(IV) complex.

With huge excess $\mathrm{Br}_{2}$, the $\mathbf{1}(\mathrm{BrNap})$ and the bimetallic $\mathbf{1}(\mathrm{DiPt})$, ring brominated to yield 2(BrNap) and 2(DiBrPt) respectively. This is shown in Scheme 2.2.11. These 
dibrominated naphthyl platinum(IV) complexes could be significant synthetic precursors for unusually brominated naphthalene compounds.<smiles>Brc1ccc([P](Br)(I)I)c2ccccc12</smiles>

1(BrNap)<smiles>[3H][P](I)(I)c1ccc([P-](Br)(I)I)c2ccccc12</smiles>

1(DiPt)

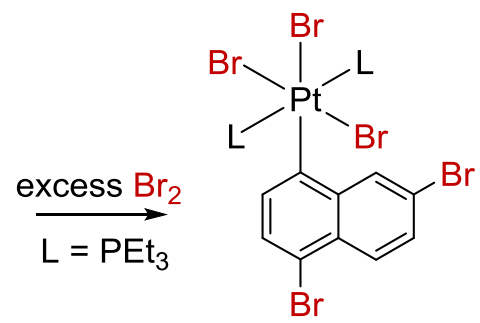

2(BrNapBr)

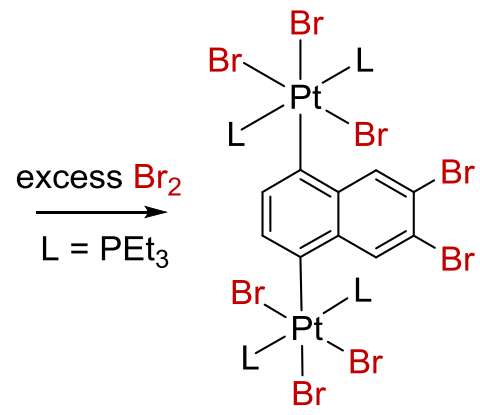

2(DiBrPt)

Scheme 2.2.11. Dibrominated naphthyl platinum(IV) complexes.

${ }^{31} \mathrm{P}$ NMR spectra is crucial in identifying the various platinum oxidation states. The coupling constants and $\delta$ are the two main factors in following the oxidation state transformations at the platinum center. This has been an invaluable handle throughout the entire project. Singlets with satellites in the $\delta-8$ to -10 region and coupling constants between $1400 \mathrm{~Hz}$ to $1650 \mathrm{~Hz}$ are indicative of the platinum(IV) species. Singlets with satellites in the $\delta 13$ to 9 region and coupling constants between $2300 \mathrm{~Hz}$ to $2800 \mathrm{~Hz}$ are 
indicative of the platinum(II) species. The corresponding ring-brominated analogues of both 2 and 1 show a small upfield shift in $\delta(<1$ unit) and about a $50 \mathrm{~Hz}$ lowering of the coupling constant in comparison to the non-ring brominated ones.

Uv-vis spectra of $\mathbf{2}$ and $\mathbf{1}$ are characteristic of their ligand framework. Complexes $\mathbf{2}$ are red shifted in comparison to $\mathbf{1}$. The absorbance in the uv region is very strong for both $\mathbf{1}$ and 2. The platinum(IV) complexes are light orange to light red in color. They have broad and weak blue absorbance in the visible region. According to DFT calculations carried out by Prof. Sharp on the lowest-energy triplet pertaining to 2, a charge transfer excited state with radical bromine character was observed. ${ }^{30,43}$ The uv-vis spectra of 2(BrNap) and 2(Phen) measured in $\mathrm{CH}_{2} \mathrm{Cl}_{2}$, hexane and dimethylformamide (DMF) were the same. Thus, band shifts associated with charge transfer transitions were not observed when solvent polarity was changed for the peaks in the visible region. ${ }^{44}$ Since the blue absorbance is weak the shifts might not be significant enough to be detected probably. The naphthyl platinum(IV) complex shows strong vibronically coupled $\pi-\pi^{*}$ bands. ${ }^{45}$ The ring bromination in 2 (BrNap) and the diplatinum in $\mathbf{1}(\mathrm{DiPt})$ contribute to bathochromic shifts. $^{45}$

\subsection{Photolysis}

Complexes 2 are light sensitive. Conversions to complexes $\mathbf{1}$ were observed in the presence of 1-hexene alkene trap and $313 \mathrm{~nm}$ light in the solution state within a few minutes. Bromine addition product 1,2-dibromohexane was observed based on ${ }^{1} \mathrm{H}$ NMR 
monitoring. Previously it was seen that photolysis of 2(1-Nap) yielded mixtures of 1(BrNap) and 1(1-Nap). The ratios of these products varied according to solvents and traps used. ${ }^{29}$ In Table 2.3.1 with cis-2-hexene trap, photolysis ratios are shown in $\mathrm{CD}_{2} \mathrm{Cl}_{2}$ and $\mathrm{CDCl}_{3}$ for 2(1-Nap). These results were important in synthesizing platinum(IV) complexes which promote net $\mathrm{Br}_{2}$ photoelimination. Hence, 2(BrNap), 2( $\left.\mathrm{BrMeO}_{2} \mathrm{Ph}\right)$, 2(BriPrOPh) and $2(\mathrm{BrNPh})$ were synthesized for $\mathrm{Br}_{2}$ photoelimination investigation. In these complexes, the possible ring bromination sites are protected by prior bromine substitution. Whilst brominating 1 to synthesize $\mathbf{2}$, the possible ring bromination positions were also brominated.

Table 2.3.1. Photolysis product yields for 2(1-Nap) with cis-2-hexene in $\mathrm{CD}_{2} \mathrm{Cl}_{2}$ and $\mathrm{CDCl}_{3}$ at $313 \mathrm{~nm}$.

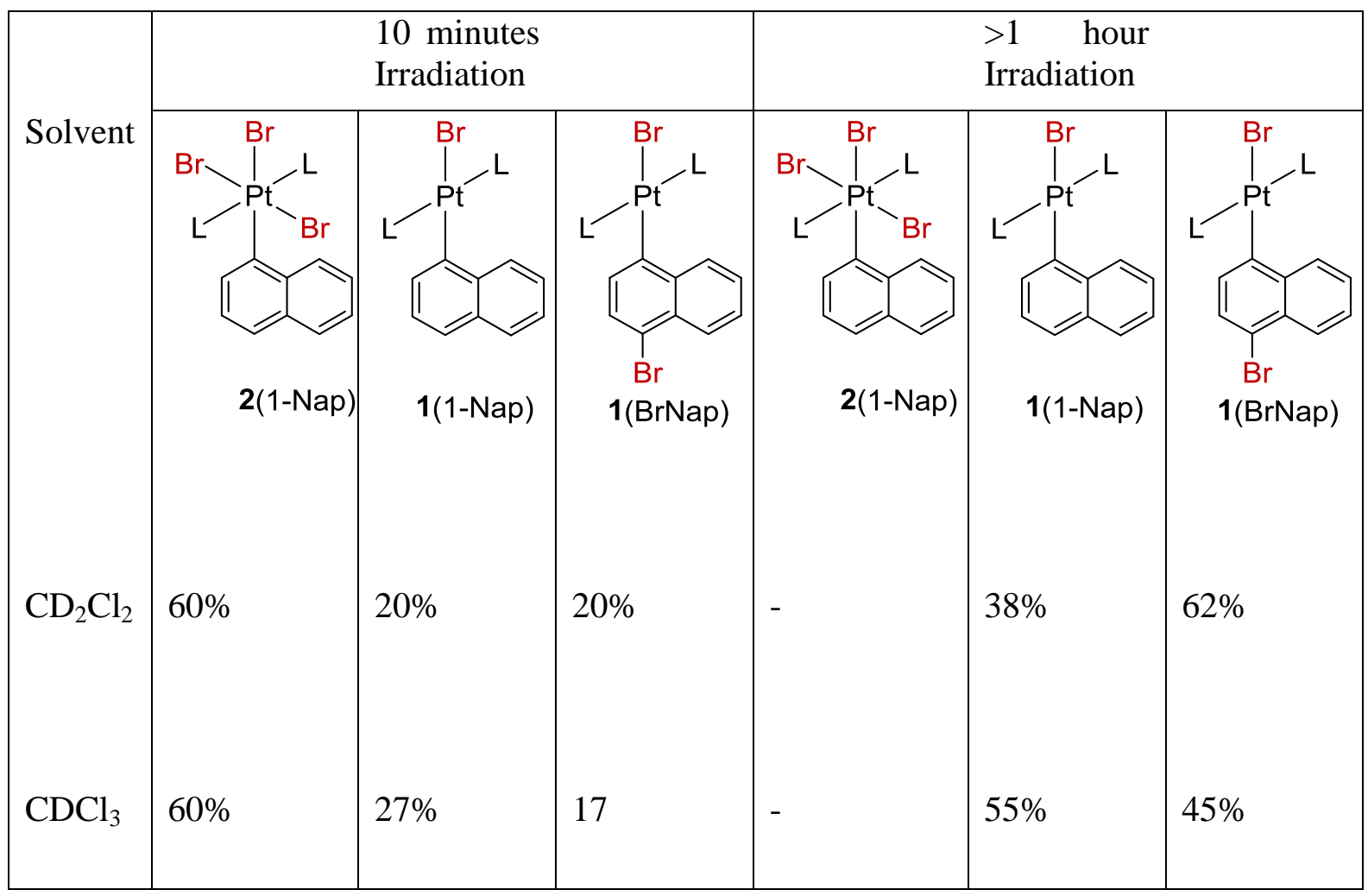


The photolysis of $\mathbf{2}$ (BrNap) in the presence of an unsymmetrical alkene like cis-2-hexene gave $96 \%$ of anti-bromine addition product as shown in Equation 2.3.1. The ${ }^{1} \mathrm{H}$ NMR shows a racemic mixture of $(2 \mathrm{R}, 3 \mathrm{~S})$ - and (2S, 3R)-2,3-dibromohexane and no synaddition product is detected. ${ }^{46}$ In the absence of trap 2(BrNap) is only weakly photoactive and shows $8 \%$ formation of $\mathbf{1}$ (BrNap) with $10 \mathrm{~min}$ photolysis. Continued irradiation shows further formation of $\mathbf{1}(\mathrm{BrNap})$ and 1,4-dibromonaphthalene. Some other products containing phosphorus are also seen. Solvent or solvent impurities can act as traps. With alkene trap and 10 min irradiation, all the 2(BrNap) converts to $\mathbf{1}(\mathrm{BrNap})$.

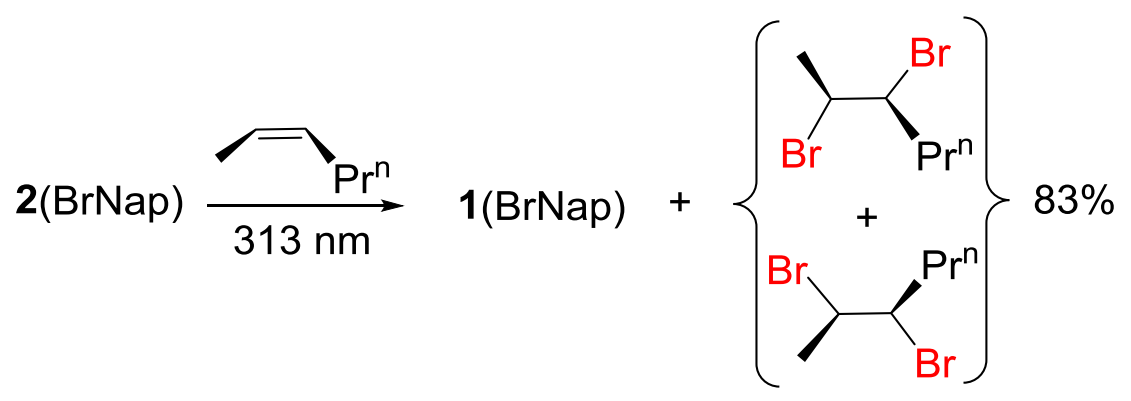

In the presence of 1-hexene trap 2(Ph) and 2(2-Nap) are nearly inactive. Prolonged irradiation (hours) does show conversion to $\mathbf{1}(\mathrm{Ph})$ and $\mathbf{1}(2-\mathrm{Nap})$ respectively. The quantum yields of $2(\mathrm{Ph})$ and $2(2-\mathrm{Nap})$ should be less than $1 \%$ as shown in Table 2.3.2. $\mathbf{2}\left(\mathrm{CF}_{3} \mathrm{Ph}\right)$ is highly light sensitive and all of it convert to $\mathbf{1}\left(\mathrm{CF}_{3} \mathrm{Ph}\right)$ very quickly. Similarly 2(BrNPh), 2( $\left.\mathrm{BrMeO}_{2} \mathrm{Ph}\right)$ and $\mathbf{2}(\mathrm{BriPrOPh})$ readily convert to $\mathbf{1}(\mathrm{BrNPh}), \mathbf{1}\left(\mathrm{BrMeO}_{2} \mathrm{Ph}\right)$ and $\mathbf{1}(\mathrm{BriPrOPh})$, respectively. No photo-induced ring bromination is observed for 2(BrNPh), 2(BriPrOPh), 2( $\left.\mathrm{BrMeO}_{2} \mathrm{Ph}\right)$ and $2\left(\mathrm{CF}_{3} \mathrm{Ph}\right)$. 
Initial photolysis of $\mathbf{2}(\mathrm{cisBr})$ showed most of it isomerizing to $\mathbf{2}(\mathrm{Br})$ along with minor amounts of $\mathbf{1}(\mathrm{Br})$ and $\mathbf{1}(\mathrm{cisBr})$. Extended photolysis gave complete conversion to $66 \%$ $\mathbf{1}(\mathrm{Br})$ and $33 \% 1(\mathrm{cisBr})$.

Photolysis of the diplatinum compound 2(DiPt) with 1-hexene alkene trap yielded a mixed valent $\mathbf{1}$ (DiPt)2 complex as shown in the Scheme 2.3.1. Based on ${ }^{1} \mathrm{H}$ and ${ }^{31} \mathrm{P}$ NMR no $\mathbf{1}(\mathrm{DiPt})$ was observed. 1,2-dibromohexane, the $\mathrm{Br}_{2}$ addition product of 1-hexene was observed.

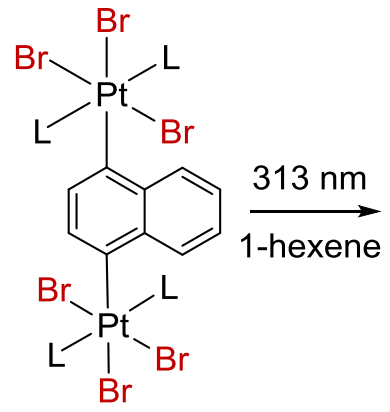

2(DiPt)

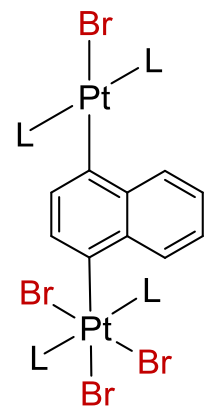

1(DiPt)2

Scheme 2.3.1. Diplatinum complex photolysis.

Using a chemical actinometer (potassium ferrioxalate) quantum yields $(\Phi)$ were measured. ${ }^{47,48}$ Thus, the $\mathrm{Br}_{2}$ photoelimination step efficiency was quantified. The values are given in Table 2.3.2. $2\left(\mathrm{CF}_{3} \mathrm{Ph}\right)$ shows a very high quantum yield of $82 \%$. One of our former group member Dr. Mehdi Masjedi's synthesis of perylene coordinated platinum(IV) complexes, allowed the photolysis to be conducted in the visible (440 nm) rather than the uv region. Perylene's strong $\pi-\pi^{*}$ transitions in the visible region enables 
this. Hence depending on the ligand environment we can shift the photolysis into the visible region as well. ${ }^{30}$

Table 2.3.2. Quantum yields $(\Phi)$ at $313 \mathrm{~nm}$ for conversion of $\mathbf{2}$ to $\mathbf{1}$ in the presence of 1hexene. ${ }^{\mathrm{a}}$

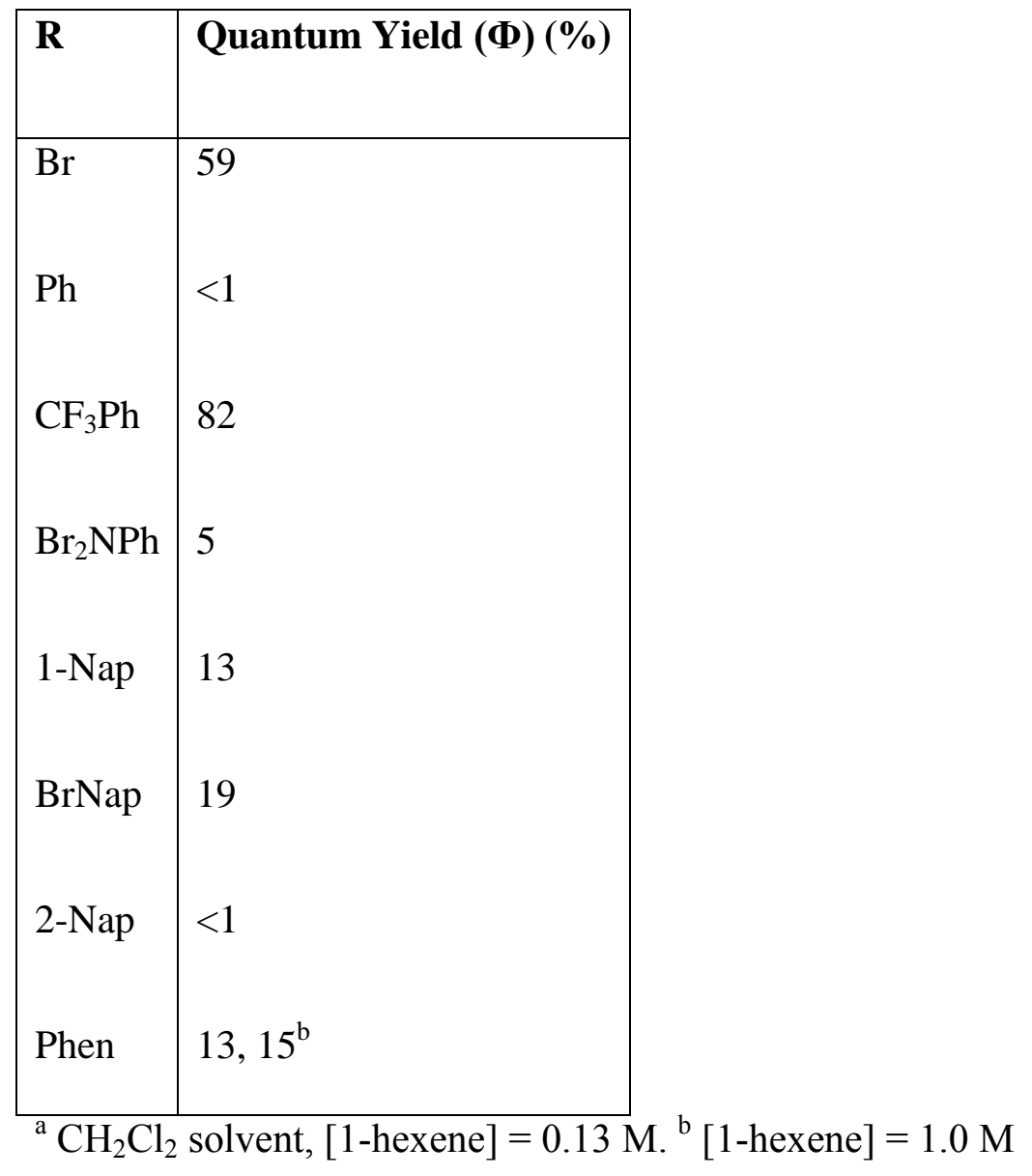

Reactivity with other traps was investigated to further understand the $\mathrm{Br}_{2}$ photoelimination process. A reactive trap like 2,3-dimethyl-2-butene (TME) unlike 1hexene and cis-2-hexene had a different product profile. Photolysis products of $\mathbf{2}(\mathrm{Br})$ and 2(BrNap) were investigated with various concentrations of TME and the results are 
shown in Table 2.3.3 and Table 2.3.4, respectively. For 2(BrNap) photolysis the corresponding $\mathbf{1}(\mathrm{BrNap})$ was seen. In the case of $\mathbf{2}(\mathrm{Br})$ we observed the isomers $\mathbf{1}(\mathrm{Br})$ and $\mathbf{1}(\mathrm{cisBr})$ as major and minor products, respectively. Photolysis of $\mathbf{2}(\mathrm{Br})$ at $313 \mathrm{~nm}$ in $\mathrm{CDCl}_{3}$ with 1-hexene alkene trap also showed the same trend. Apart from the TME $\mathrm{Br}_{2}$ addition product 2,3-dimethyl-2,3-dibromobutane (3), ${ }^{49}$ we observe some allylic bromination product 1-bromo-2,3-dimethyl-2-butene $(\mathbf{4})^{50,51}$ as well. Also 2-bromo-2,3dimethylbutane (5) is detected. ${ }^{49} \mathrm{HBr}$ generated from production of $\mathbf{4}$ reacts with TME to yield 5. Yield of 4 increased with increasing trap (TME) concentrations. Similar reaction trends are observed for 2 (BrNap) as well as shown in Table 2.3.4. The alkene reaction product profile, depends on the reaction conditions and is very sensitive to impurities in solvents and traps. Hence, these experiments were carried out in drybox conditions and anhydrous solvents. In contrast, photolysis of an organoplatinum(IV) perylene derivative prepared by $\mathrm{Dr}$. Masjedi, exclusively gave the $\mathrm{Br}_{2}$ addition product $\mathbf{3}$ over TME concentrations varying from 22 to $560 \mathrm{mM}^{30}$ 
Table 2.3.3. Photolysis product yields ${ }^{\mathrm{a}}$ for trans- $\mathrm{Pt}\left(\mathrm{PEt}_{3}\right)_{2}(\mathrm{Br})_{4}(2(\mathrm{Br}))^{\mathrm{b}}$ with 2,3-dimethyl-2butene (TME) trap at $313 \mathrm{~nm}$ in $\mathrm{CDCl}_{3}$.

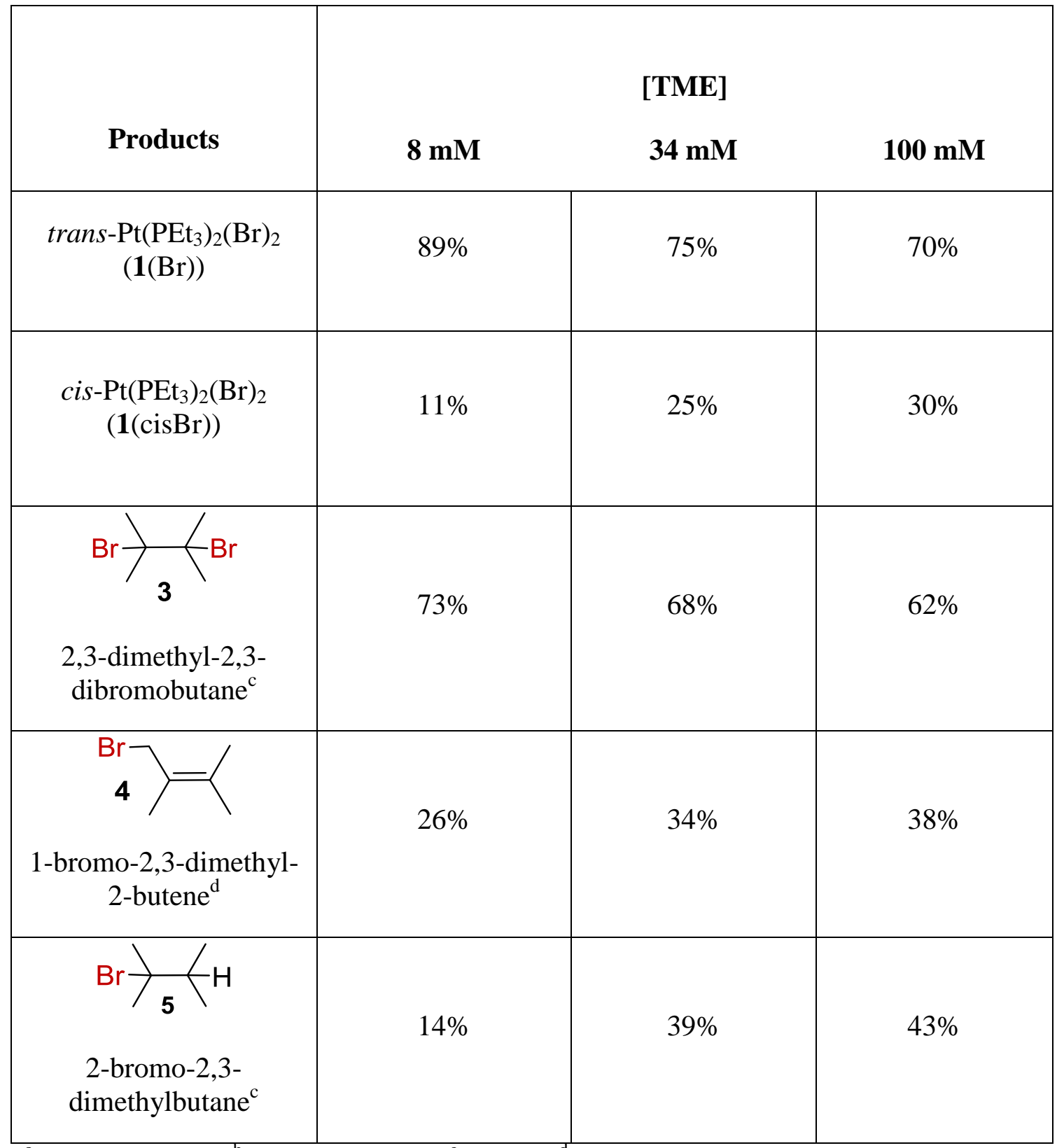

${ }^{\mathrm{a}}$ Based on 2(Br). ${ }^{\mathrm{b}}[\mathbf{2}(\mathrm{Br})]=4 \mathrm{mM} .{ }^{\mathrm{c}} \operatorname{Ref} 49 .{ }^{\mathrm{d}} \operatorname{Refs} 50$ and 51. 
Table 2.3.4. Photolysis product yields ${ }^{\mathrm{a}}$ for trans- $\mathrm{Pt}\left(\mathrm{PEt}_{3}\right)_{2}(\mathrm{Br})_{3}(4-\mathrm{BrNap})(2(\mathrm{BrNap}))^{\mathrm{b}}$ with 2,3-dimethyl-2-butene (TME) trap at $313 \mathrm{~nm}$ in $\mathrm{CDCl}_{3}$.

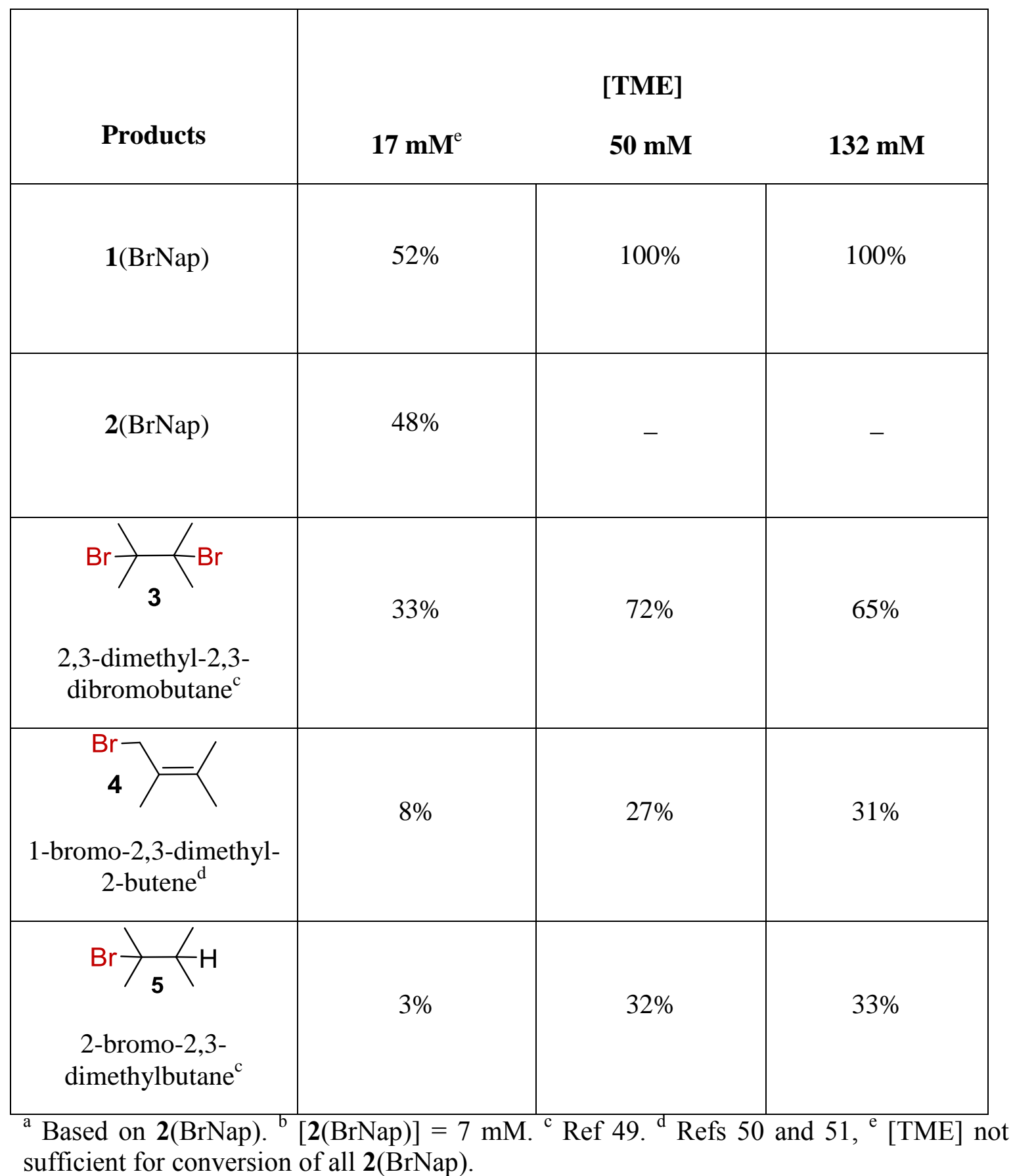


Evidence for molecular bromine $\left(\mathrm{Br}_{2}\right)$ as the brominating agent for the alkene trap was also found in a competition experiment. Photolysis of 2(BrNap) with an excess 1:1 mixture of 1-hexene and trans-3-hexene was carried out at $313 \mathrm{~nm}$ in $\mathrm{CDCl}_{3}$ ( $\mathrm{Scheme}$ 2.3.2). ${ }^{35,52}$ Only trans-3-hexene brominated product 3,4-trans-dibromohexane (6) was seen. 1,2-dibromohexane (7) was not observed. Alternatively to an excess 1:1 mixture of trans-3-hexene and 1-hexene, when a solution of $\mathrm{Br}_{2}$ in $\mathrm{CDCl}_{3}$ was added, 3,4-transdibromohexane was only observed. The 1-hexene addition product 1,2-dibromohexane was not seen. The solution of $\mathrm{Br}_{2}$ in $\mathrm{CDCl}_{3}$ was added slowly with vigorous stirring to mimic the conditions of $\mathrm{Br}_{2}$ photoelimination from $\mathbf{2}$ (BrNap).
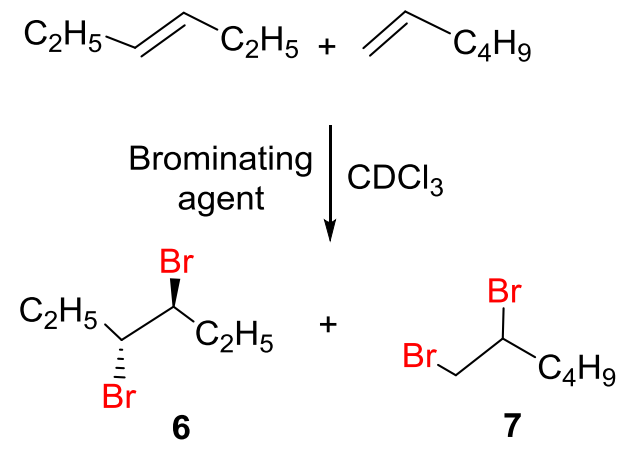

\begin{tabular}{cr}
$\begin{array}{c}\text { Brominating } \\
\text { agent }\end{array}$ & Product seen \\
\hline $\mathrm{Br}_{2}$ & $\mathbf{6}(100 \%)$ \\
$\mathbf{2}(\mathrm{BrNap})+\mathrm{hv}$ & $\mathbf{6}(100 \%)$
\end{tabular}

Scheme 2.3.2. Alkene trap competition experiment. 


\subsection{HBr Photolysis}

Gaseous $\mathrm{HBr}$ was added to platinum(II) complexes to check for oxidative addition and ring bromination products. This is illustrated in Scheme 2.4.1. Addition of gaseous $\mathrm{HBr}$ to $\mathrm{CDCl}_{3}$ solutions of $\mathbf{1}(1-\mathrm{Nap})$ and $\mathbf{1}(\mathrm{Phen})$ showed no reaction. Further photolysis of the same solutions at $313 \mathrm{~nm}$ also showed no reaction. Neither photolytic oxidative addition of $\mathrm{HBr}$ to the platinum(II) center nor bromination of the naphthyl or phenanthryl ring is seen. $\mathrm{HBr}$ addition to the metal center photolytically or thermally is an important step in the realization of the $\mathrm{HBr}$ splitting cycle by a metal catalyst.
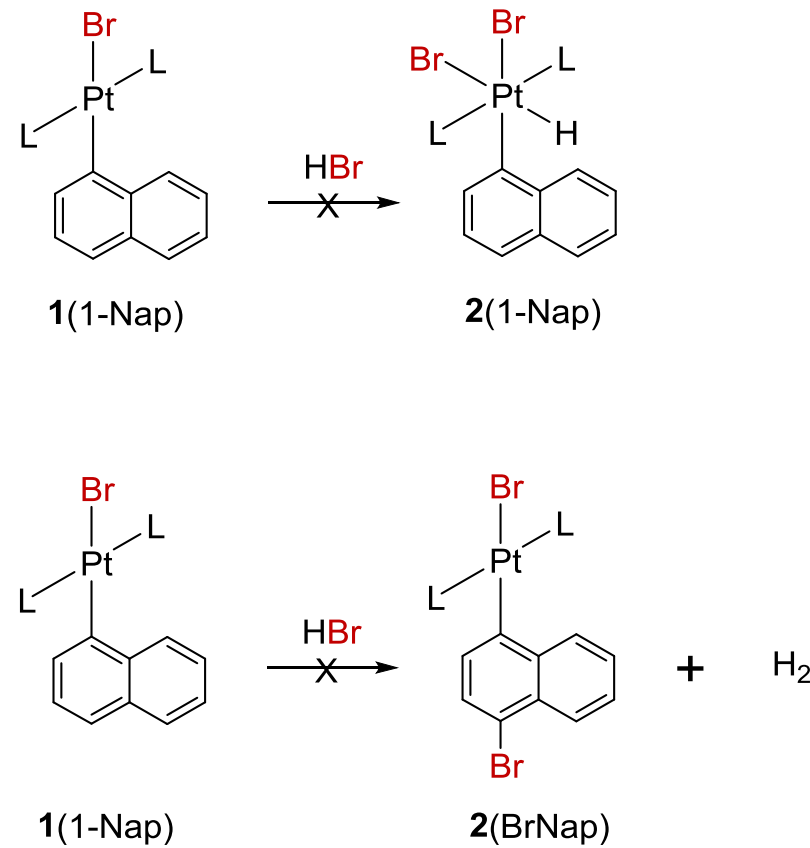

Scheme 2.4.1. $\mathrm{HBr}$ addition to platinum(II) complex. 


\subsection{Photokinetics}

Photolysis kinetic measurements were carried out in the presence of $313 \mathrm{~nm}$ radiation. The reaction rate is zero order in terms of $\mathbf{2}(\mathrm{BrNap})$. The photon flux is rate limiting. The photolysis rate is affected by the reactivity of the traps. Measurements were carried out in TME and 1-Hexene as shown in Figures 2.5.1 and 2.5.2. The rate is doubled with TME as trap in comparison to 1-hexene. With TME the rate constant is $1.2( \pm 1) \mathrm{X} 10^{-3} \mathrm{Mmin}^{-1}$. The rate constant with 1-hexene is $6( \pm 1) \times 10^{-4} \mathrm{Mmin}^{-1}$. The error percentages are based on $4 \%$ error associated with ${ }^{31} \mathrm{P}$ integration. ${ }^{36}$

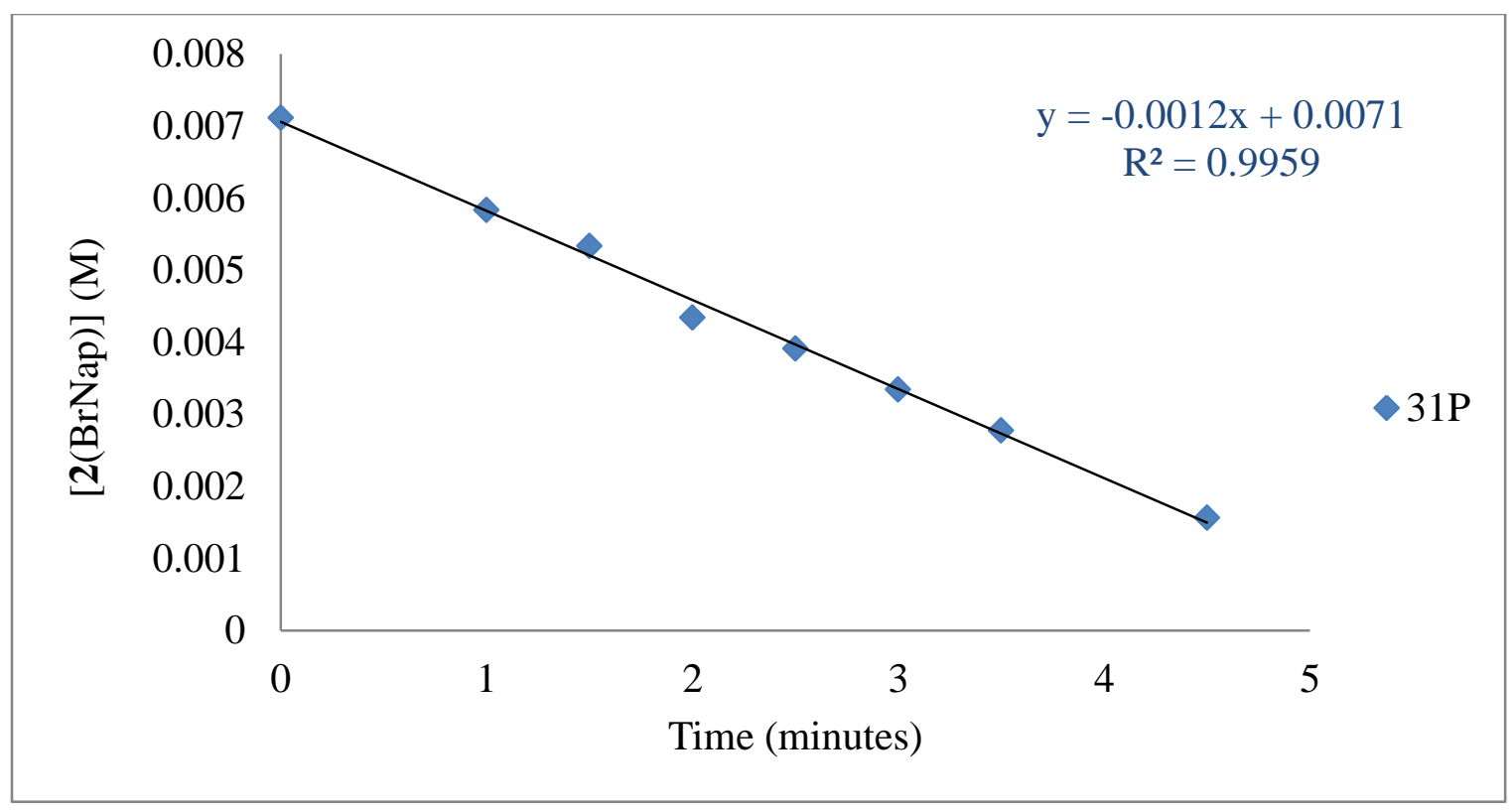

Figure 2.5.1. Kinetic plot (tablefrom ${ }^{31} \mathrm{P}$ ) for the photolysis of trans- $\mathrm{Pt}\left(\mathrm{PEt}_{3}\right)_{2}(\mathrm{Br})_{3}(4-$ BrNap) 2(BrNap) with TME (0.48 M) at $313 \mathrm{~nm}$ in $\mathrm{CDCl}_{3}$. 


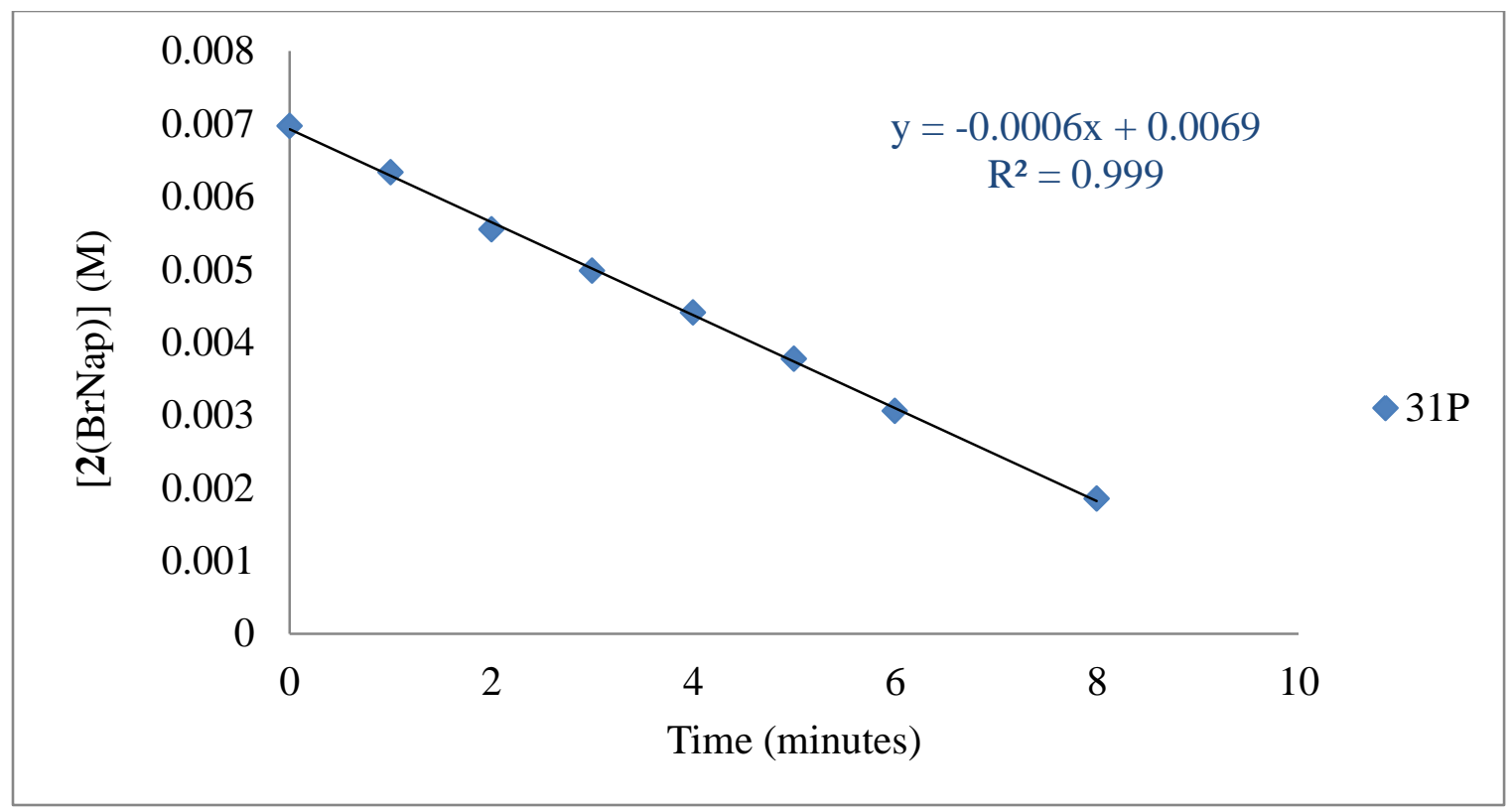

Figure 2.5.2. Kinetic plot (from ${ }^{31} \mathrm{P}$ ) for the photolysis of trans- $\mathrm{Pt}\left(\mathrm{PEt}_{3}\right)_{2}(\mathrm{Br})_{3}(4-\mathrm{BrNap})$ 2(BrNap) with 1-hexene $(0.46 \mathrm{M})$ at $313 \mathrm{~nm}$ in $\mathrm{CDCl}_{3}$.

The photolysis rate was unaffected by the presence of gaseous oxygen. 2(BrNap) photolysis $(313 \mathrm{~nm})$ with 1 -hexene was monitored after the addition of $\mathrm{O}_{2}$ gas as shown in Figure 2.5.3. The rate constant $6( \pm 1) \times 10^{-4} \mathrm{Mmin}^{-1}$ in the presence of oxygen was the same as in the absence of oxygen. The error percentages are based on $4 \%$ error associated with ${ }^{31} \mathrm{P}$ integration. ${ }^{36}$ There is no quenching by $\mathrm{O}_{2}$. Quenching by paramagnetic $\mathrm{O}_{2}$ is significant in the case of triplet excited states usually. 


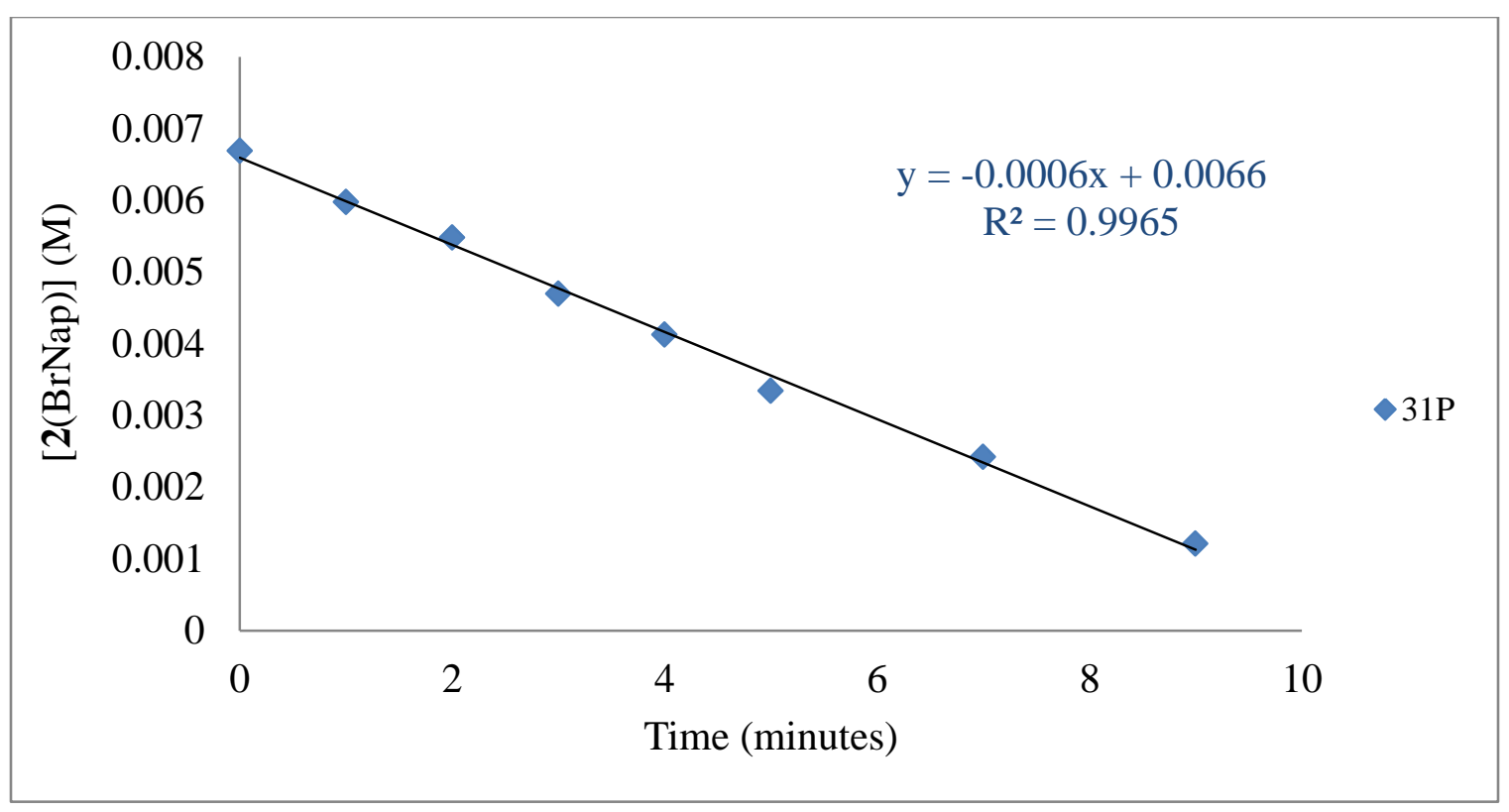

Figure 2.5.3. Kinetic plot (from ${ }^{31} \mathrm{P}$ ) for the photolysis of trans- $\mathrm{Pt}\left(\mathrm{PEt}_{3}\right)_{2}(\mathrm{Br})_{3}(4-\mathrm{BrNap})$ 2(BrNap) with 1-hexene $(0.46 \mathrm{M})$ at $313 \mathrm{~nm}$ in $\mathrm{CDCl}_{3}$ in the presence of oxygen.

To check for photoelimination of $\mathrm{Br}_{2}$, photokinetic monitoring of $2(\mathrm{BrNap})$ at $380 \mathrm{~nm}$ was undertaken with trap in the presence and absence of $\mathbf{1}$ (BrNap). At $380 \mathrm{~nm} \mathrm{1(BrNap)}$ has no absorption and 2 (BrNap) has a molar extinction coefficient of $2976 \mathrm{M}^{-1} \mathrm{~cm}^{-1} . \mathrm{Br}_{2}$ molar extinction coefficient at $380 \mathrm{~nm}$ is $\sim 106 \mathrm{M}^{-1} \mathrm{~cm}^{-1}$. 2(BrNap) photolysis at $380 \mathrm{~nm}$ with excess 1-hexene follows zero order dependence on the concentration of 2 (BrNap).

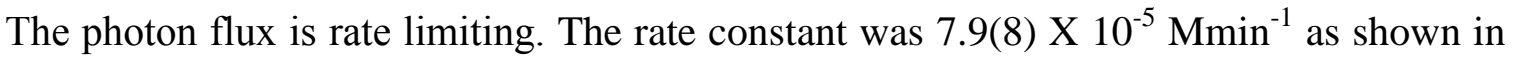
Figure 2.5.4. 


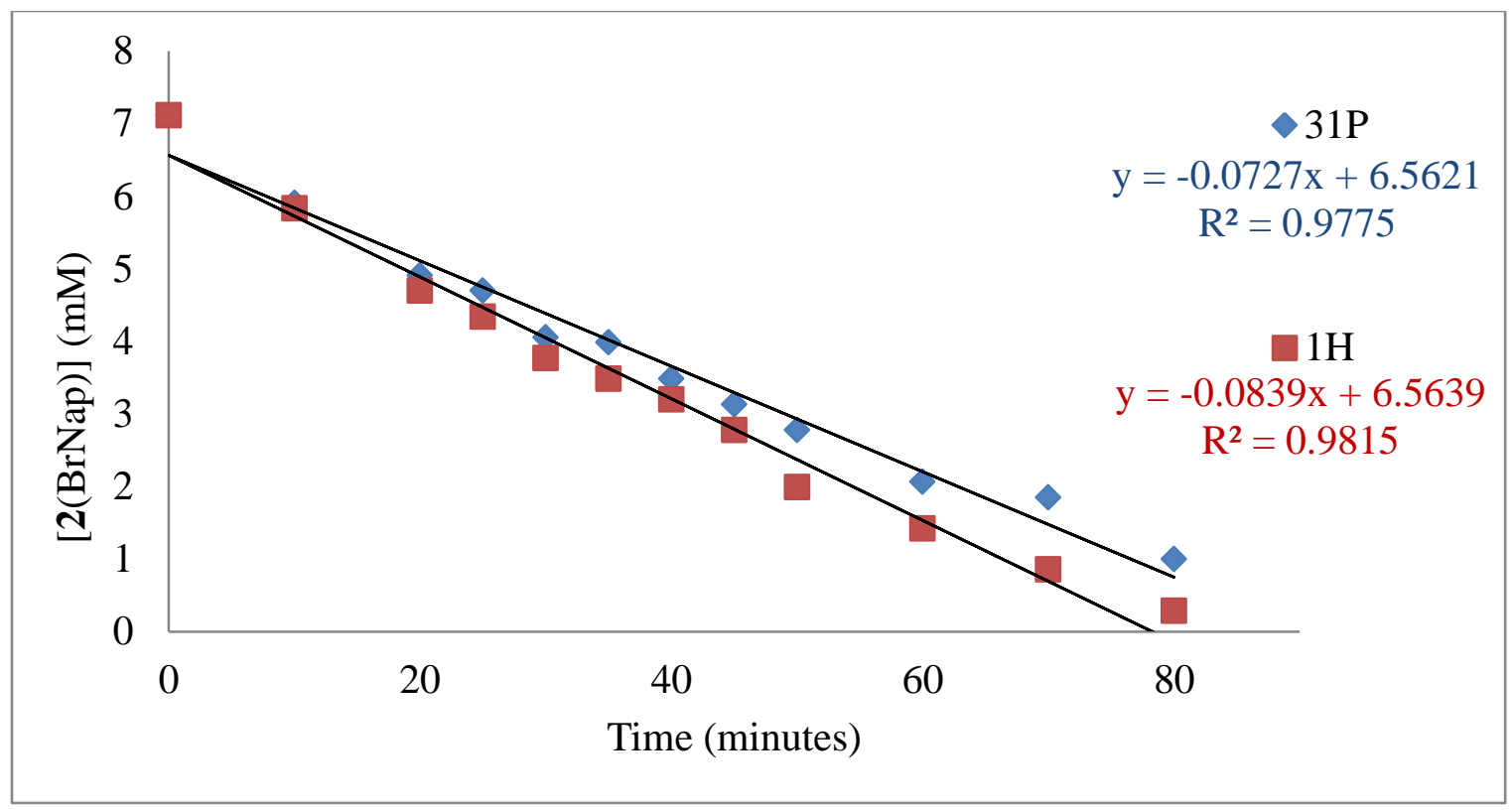

Figure 2.5.4. Kinetic plot (from ${ }^{31} \mathrm{P}$ and ${ }^{1} \mathrm{H}$ NMR) for the photolysis of trans$\mathrm{Pt}\left(\mathrm{PEt}_{3}\right)_{2}(\mathrm{Br})_{3}(4-\mathrm{BrNap})$ 2(BrNap) with 1-hexene $(0.46 \mathrm{M})$ at $380 \mathrm{~nm}$ in $\mathrm{CDCl}_{3}$.

$\mathbf{2}$ (BrNap) photolysis at $380 \mathrm{~nm}$ with excess 1-hexene in the presence of $\mathbf{1}$ (BrNap) also follows zero order dependence with concentration of $\mathbf{2}$ (BrNap). The photon flux is rate limiting. But the rate constant is decreased almost by half and has a value of 4.1(3) $\mathrm{X} 10^{-5}$ $\mathrm{Mmin}^{-1}$ as shown in Figure 2.5.5 1 (BrNap) competes with the trap (1-hexene) for the photogenerated $\mathrm{Br}_{2}$ and hence probably we see the decrease in the rate. 


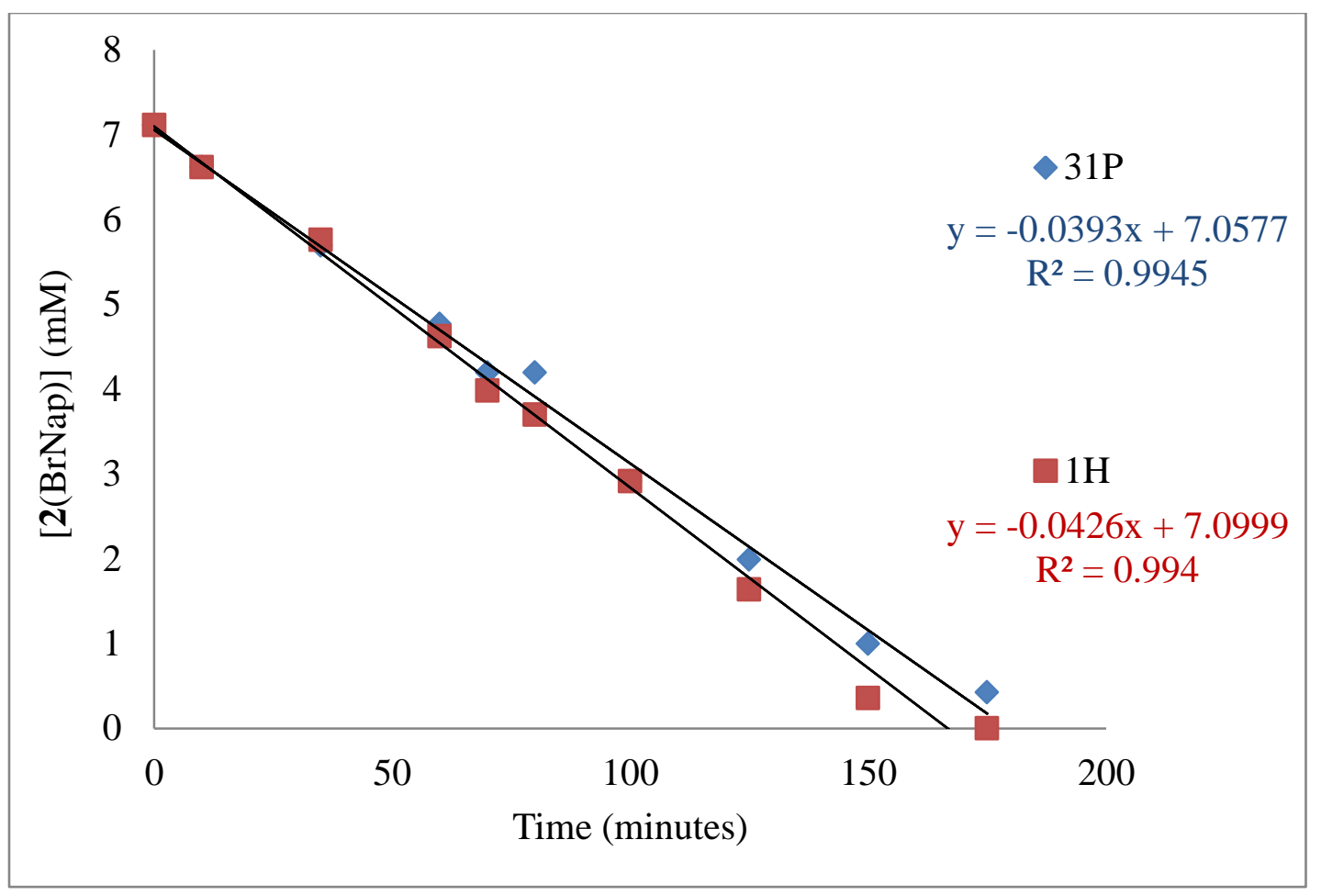

Figure 2.5.5. Kinetic plot (from ${ }^{31} \mathrm{P}$ and ${ }^{1} \mathrm{H}$ NMR) for the photolysis of trans$\mathrm{Pt}\left(\mathrm{PEt}_{3}\right)_{2}(\mathrm{Br})_{3}(4-\mathrm{BrNap}) 2$ (BrNap) with 1-hexene $(0.46 \mathrm{M})$ in the presence of trans$\mathrm{Pt}\left(\mathrm{PEt}_{3}\right)_{2}(\mathrm{Br})(4-\mathrm{BrNap}) \mathbf{1}(\mathrm{BrNap})$ at $380 \mathrm{~nm}$ in $\mathrm{CDCl}_{3}$. (Beginning 2(BrNap):1(BrNap) ratio is $44: 56$ )

\subsection{Thermal reactions}

Complexes 2 eliminate $\mathrm{Br}_{2}$ and convert to $\mathbf{1}$ in the presence of traps through the thermal pathway as well. Thermal conversion happens at room temperature and shows first-order dependence with regards to $2\left(\mathrm{CF}_{3} \mathrm{Ph}\right)$ as shown in Figures 2.6.1-2.6.3. The average rate constant is $1.4(2) \mathrm{X}^{-3} 0^{-3} \mathrm{~min}^{-1}$. The thermochemistry significance of this rate constant is explained in the discussion section. The reaction rate is independent of the alkene concentration. Experiments were carried out in the presence of 1-hexene ranging from $0.096 \mathrm{M}$ to $0.38 \mathrm{M}$. Thermolysis rate is affected by solvent polarity. Reaction of $\mathbf{2}\left(\mathrm{CF}_{3} \mathrm{Ph}\right)$ in benzene with trap showed only $5-10 \%$ conversion to $\mathbf{1}\left(\mathrm{CF}_{3} \mathrm{Ph}\right)$ after nearly 
four days. In comparison all of $\mathbf{2}\left(\mathrm{CF}_{3} \mathrm{Ph}\right)$ converted to $\mathbf{1}\left(\mathrm{CF}_{3} \mathrm{Ph}\right)$ within 2 days in $\mathrm{CDCl}_{3}$. Hence, the rate determining step probably involves a polar transition state.

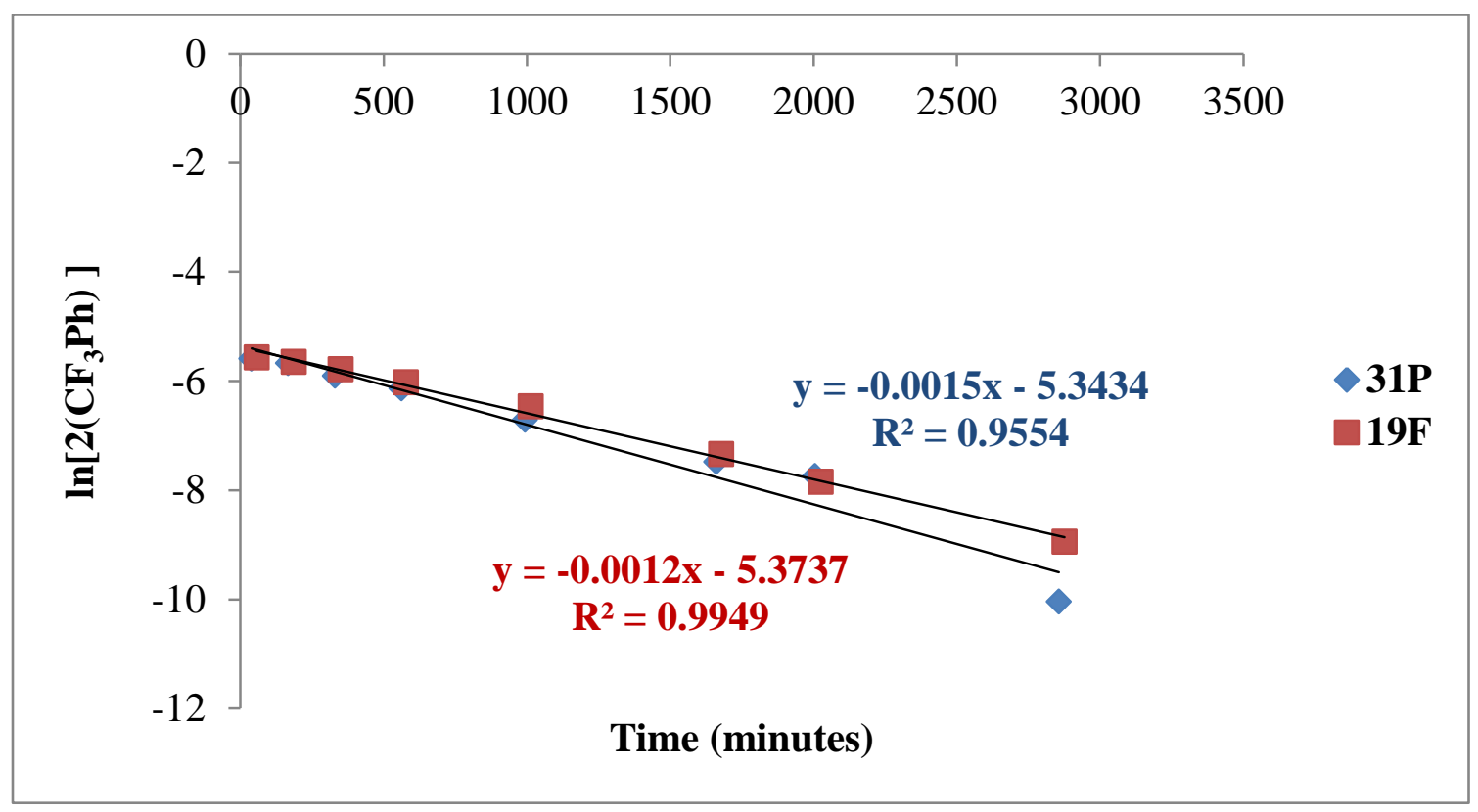

Figure 2.6.1. Kinetic plot (from ${ }^{31} \mathrm{P}$ and ${ }^{19} \mathrm{~F}$ NMR) for the 1-hexene dark reaction of trans $-\mathrm{Pt}\left(\mathrm{PEt}_{3}\right)_{2}(\mathrm{Br})_{3}\left(\mathrm{CF}_{3} \mathrm{Ph}\right) 2\left(\mathrm{CF}_{3} \mathrm{Ph}\right)(4.3 \mathrm{mM})$ at $300 \mathrm{~K}$ and [1-hexene] $=0.096 \mathrm{M}$ in $\mathrm{CDCl}_{3}$. 


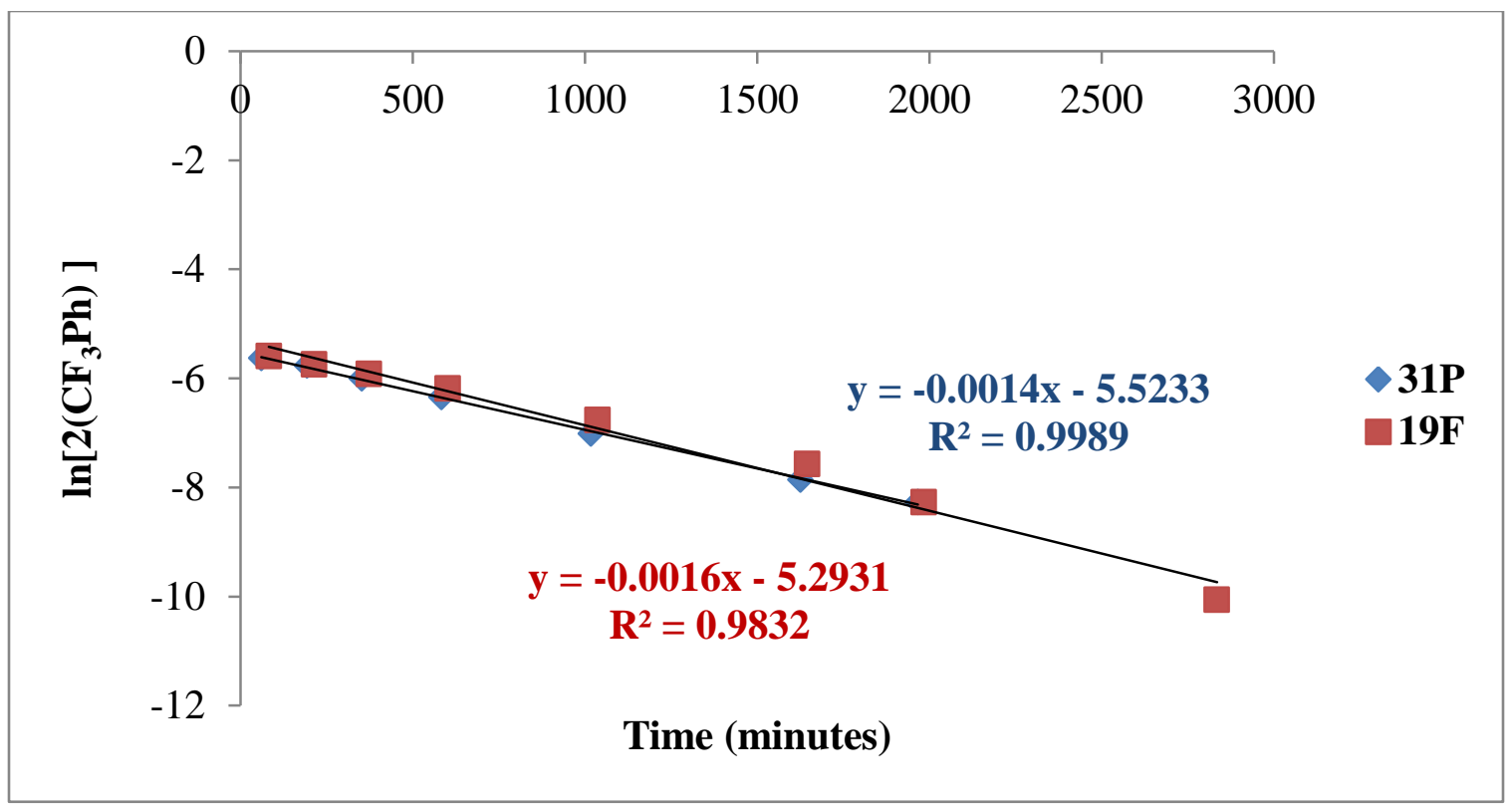

Figure 2.6.2. Kinetic plot (from ${ }^{31} \mathrm{P}$ and ${ }^{19} \mathrm{~F}$ NMR) for the 1-hexene dark reaction of trans $-\mathrm{Pt}\left(\mathrm{PEt}_{3}\right)_{2}(\mathrm{Br})_{3}\left(\mathrm{CF}_{3} \mathrm{Ph}\right) 2\left(\mathrm{CF}_{3} \mathrm{Ph}\right)(4.3 \mathrm{mM})$ at $300 \mathrm{~K}$ and $[1$-hexene] $=0.19 \mathrm{M}$ in $\mathrm{CDCl}_{3}$.

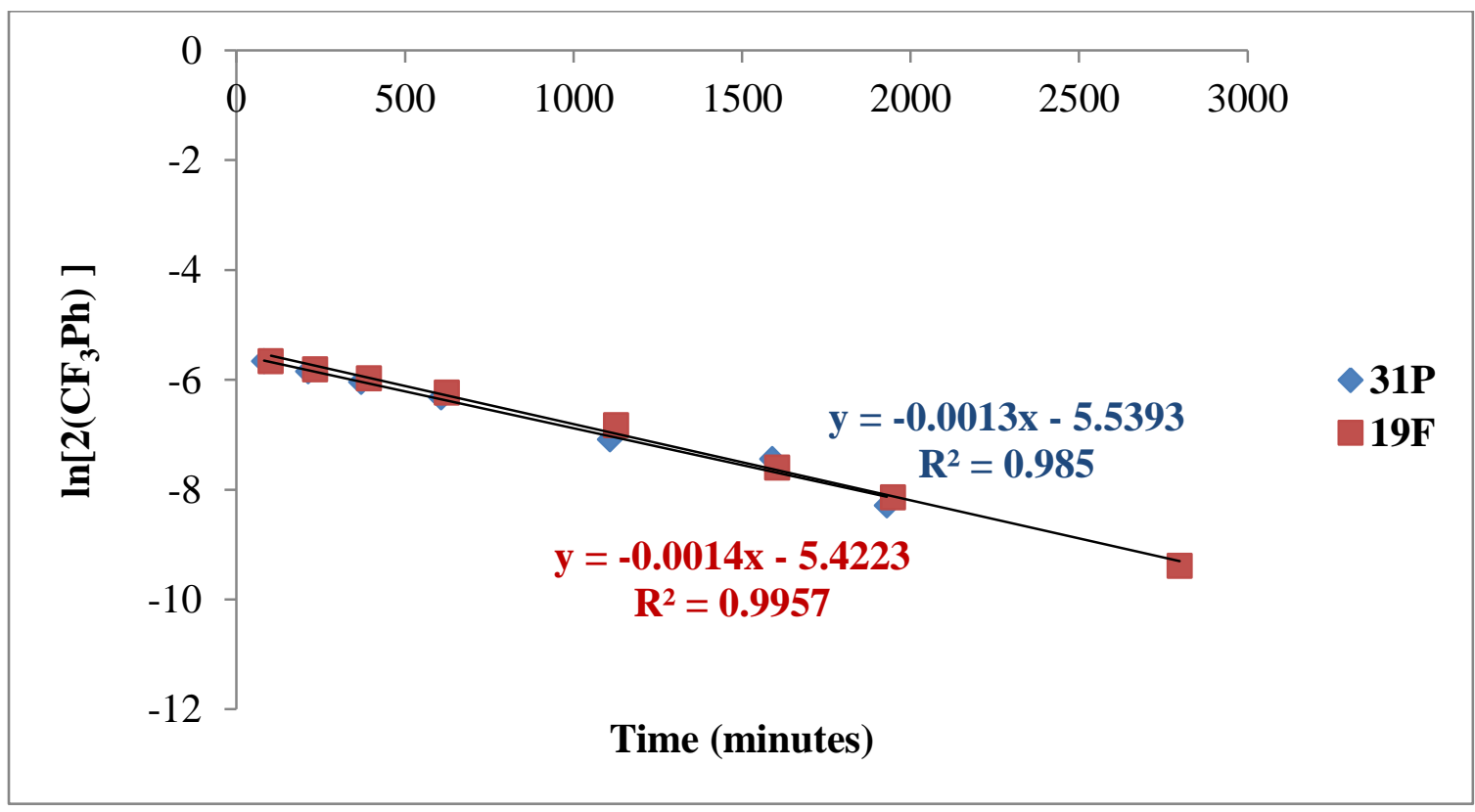

Figure 2.6.3. Kinetic plot (from ${ }^{31} \mathrm{P}$ and ${ }^{1} \mathrm{H}$ NMR) for the 1-hexene dark reaction of trans $-\mathrm{Pt}\left(\mathrm{PEt}_{3}\right)_{2}(\mathrm{Br})_{3}\left(\mathrm{CF}_{3} \mathrm{Ph}\right) 2\left(\mathrm{CF}_{3} \mathrm{Ph}\right)(4.2 \mathrm{mM})$ at $300 \mathrm{~K}$ and [1-hexene] $=0.38 \mathrm{M}$ in $\mathrm{CDCl}_{3}$. 
The other 2 complexes are stable in the presence of the trap at room temperature. But conversion of $\mathbf{2}$ to $\mathbf{1}$ is seen at temperatures varying from 50 to $120{ }^{\circ} \mathrm{C}$. Thermolysis kinetics of $\mathbf{2}$ (BrNap) conversion to $\mathbf{1}(\mathrm{BrNap})$ was monitored in the presence of trap in $\mathrm{CDCl}_{3}$ at $325 \mathrm{~K}$. The rate constant was $9( \pm 1) \times 10^{-4} \mathrm{~min}^{-1}$. The thermochemistry significance of this rate constant is explained in the discussion section. The error percentage is based on $4 \%$ error associated with ${ }^{31} \mathrm{P}$ integration. ${ }^{36}$ The thermal reaction had first-order dependence in $\mathbf{2}$ (BrNap) concentration as shown in Figure 2.6.4. Thermolysis of 2(1-Nap) with trap in $\mathrm{CDCl}_{3}$, yields $59 \%$ of $\mathbf{1}(\mathrm{BrNap})$ and $41 \%$ of $\mathbf{1}(1-$ Nap). This ratio is the reverse of the photolysis ratio.

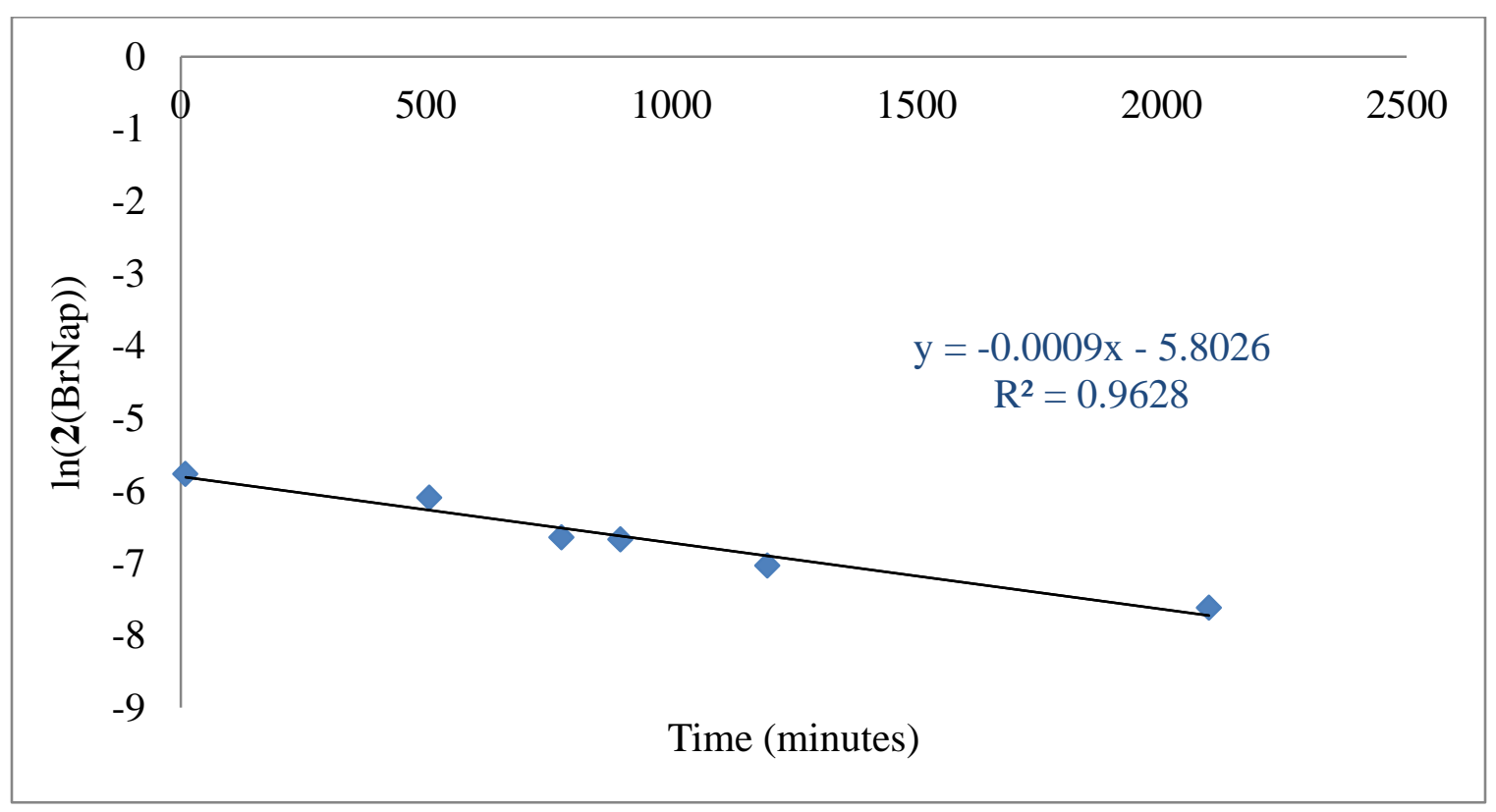

Figure 2.6.4. Kinetic plot (from ${ }^{31} \mathrm{P}$ ) for the 1-hexene dark reaction of trans$\mathrm{Pt}\left(\mathrm{PEt}_{3}\right)_{2}(\mathrm{Br})_{3}(4-\mathrm{BrNap}) 2(\mathrm{NapBr})(3.1 \mathrm{mM})$ at $325 \mathrm{~K}$ and [1-hexene] $=0.31 \mathrm{M}$ in $\mathrm{CDCl}_{3}$. 


\section{$2.7 \mathrm{Br}_{2}$ addition to platinum(II) versus alkene}

Bromination competition experiments were carried out to check the rate of $\mathrm{Br}_{2}$ addition to 2(BrNap) versus 1-hexene. This is shown in Equations 2.7.1 and 2.7.2.

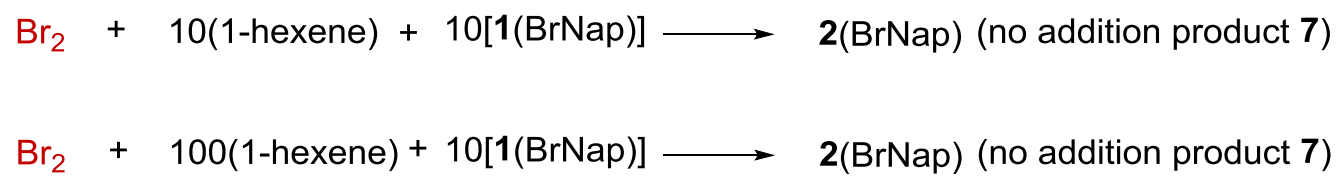

Addition of $\mathrm{Br}_{2}$ to a 1:1 ratio of $\mathbf{1}(\mathrm{BrNap})$ :1-hexene reaction mixture showed bromination of $\mathbf{1}$ (BrNap). 2(BrNap) was observed based on ${ }^{1} \mathrm{H}$ and ${ }^{31} \mathrm{P}$ NMR. The 1-hexene addition product 1,2-dibromohexane (7) was not seen. Addition of $\mathrm{Br}_{2}$ to a 1:10 ratio of 1(BrNap):1-hexene reaction mixture also showed bromination of $\mathbf{1}$ (BrNap) only. 2(BrNap) was observed rather than the alkene addition product 7. $\mathrm{Br}_{2}$ solution was added in one shot to the $\mathbf{1}(\mathrm{BrNap})$ :1-hexene reaction mixture under constant stirring. This suggests that bromination of platinum(II) is at least 10 times faster than $\mathrm{Br}_{2}$ addition to 1hexene.

\subsection{Low temperature photoemission}

2(BrNap) and $2(\mathrm{Br})$ in 2-methyltetrahydrofuran glass at $77 \mathrm{~K}$ showed no low-temperature photoemission. 1(BrNap) in 2-methyltetrahydrofuran (MeTHF) glass at $77 \mathrm{~K}$ showed yellowish green colored low-temperature photoemission with excitation at $360 \mathrm{~nm}$ and 
$340 \mathrm{~nm}$. Broad emission spectra with structured emission bands at 520 and $564 \mathrm{~nm}$ are observed as shown in Figure 2.8.1.
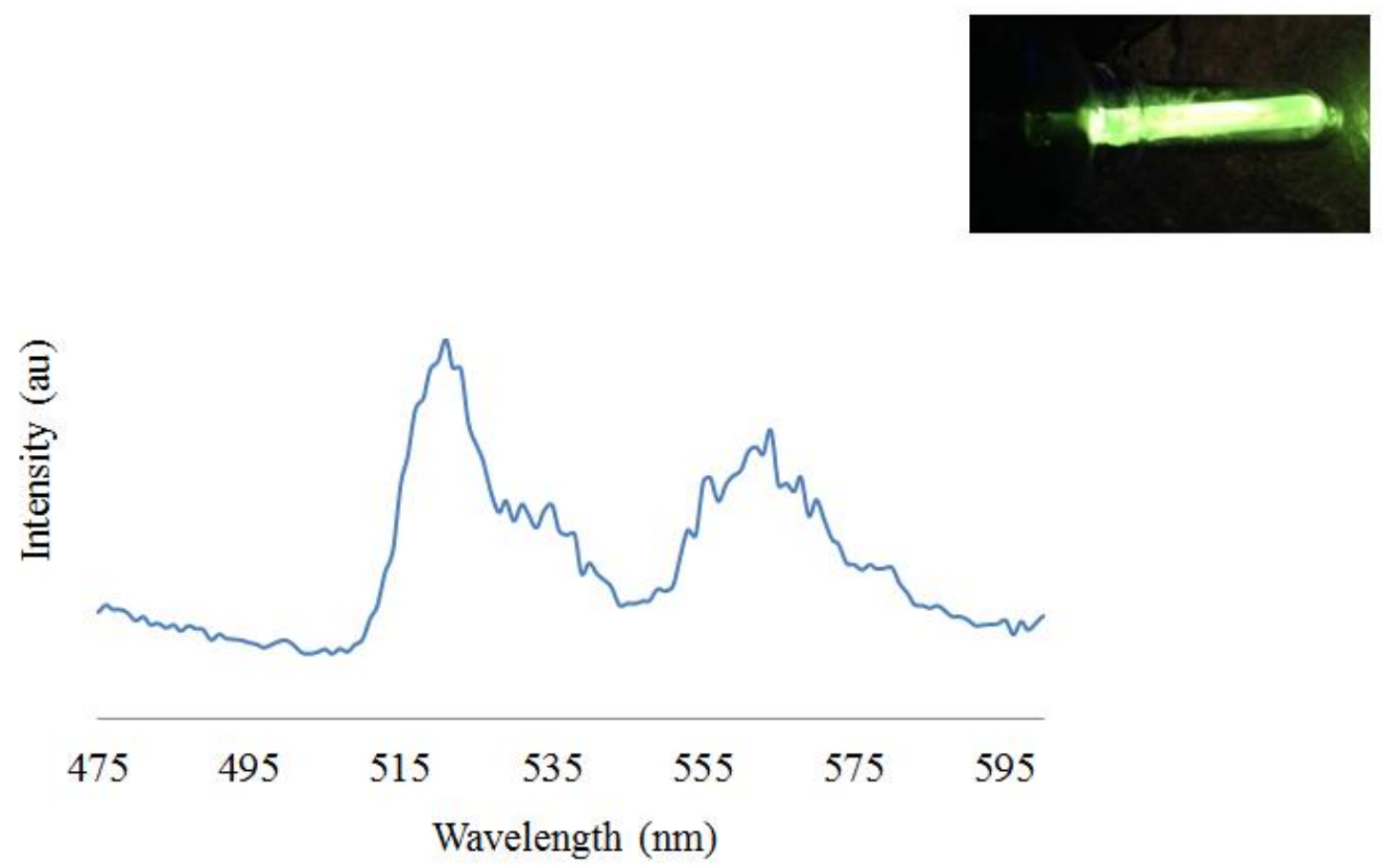

Figure 2.8.1. Photoemission spectrum of trans- $\mathrm{Pt}\left(\mathrm{PEt}_{3}\right)_{2}(\mathrm{Br})$ (4-bromo-1-naphthyl) 1(BrNap) in 2-methyltetrahydrofuran glass at $77 \mathrm{~K}$ with $360 \mathrm{~nm}$ excitation.

The emission at $520 \mathrm{~nm}$ shows exponential decay with a mean life time of $332 \mu \mathrm{s}$ as shown in figure 2.8. This decay is also visually observed. As soon as the solution is warmed to room temperature the yellowish green color quickly fades. The long life time is indicative of the phosphorescence of the napthalenyl ring which shows emission at $471,480,483,504,506,509,510,514,518,523 \mathrm{~nm}^{53,54}$ Photochemistry of $\mathbf{2}(\mathrm{Br})$ and 2(BrNap) with trap at $77 \mathrm{~K}$ in MeTHF is very slow. The molecules are held rigidly in the frozen matrix. 


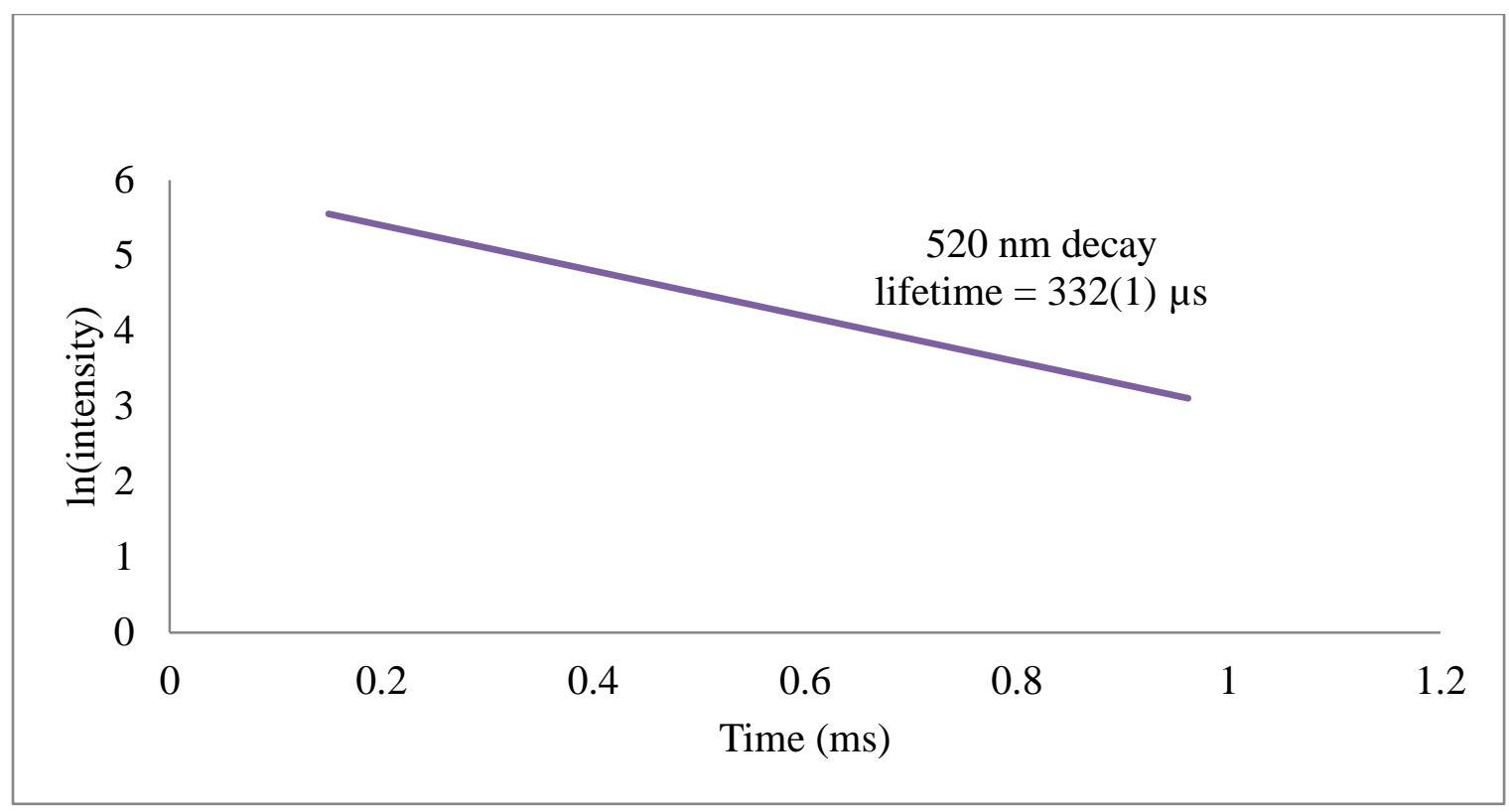

Figure 2.8.2 Emission decay at $520 \mathrm{~nm}$ for trans- $\mathrm{Pt}\left(\mathrm{PEt}_{3}\right)_{2}(\mathrm{Br})(4-$ bromo-1-naphthyl) $\mathbf{1}(\mathrm{BrNap})$ in 2-methyltetrahydrofuran glass at $77 \mathrm{~K}$, lifetime $=332(1) \mu \mathrm{s}, \lambda($ excitation$)=$ $360 \mathrm{~nm}$, gate time $=0.1 \mathrm{~ms}$ and delay time $=0.1 \mathrm{~ms}$.

\subsection{Solid state photolysis}

We see solid state conversion of to $\mathbf{2}(\mathrm{NapBr})$ to $\mathbf{1}(\mathrm{NapBr})$ in the presence of $313 \mathrm{~nm}$ light. Photolysis of $2(\mathrm{NapBr})$ deposited on the sides of a quartz NMR tube by solvent evaporation shows conversion to $\mathbf{1}(\mathrm{NapBr})$. This can be seen from the orange to yellow color change in some areas. When the volatiles were condensed onto a frozen solution containing 1-hexene, the bromine addition products were seen using ${ }^{1} \mathrm{H}$ NMR spectroscopy. Rate of photoconversion was affected by experimental conditions (deposit thickness and residual solvent). Interestingly, 2(1-Nap) in the solid state over the course of a year yielded ring-brominated $\mathbf{1}(\mathrm{BrNap})$ exclusively. Further investigation and $\mathrm{Br}_{2}$ elimination yield measurement is required. Previously solid state $\mathrm{Br}_{2}$ and $\mathrm{Cl}_{2}$ elimination 
from gold and platinum systems were reported by the Nocera group. ${ }^{21,32}$ No yields were reported though.

\subsection{Calorimetry}

The bromine reaction enthalpies of the four complexes $\mathbf{1}(\mathrm{Br}), \mathbf{1}(\mathrm{Ph}), \mathbf{1}\left(\mathrm{CF}_{3} \mathrm{Ph}\right)$ and 1(BrNap) were determined in toluene by the Hoff group using calorimetry. ${ }^{30}$ The gasphase DFT calculations on 1' $\left(\mathrm{PMe}_{3}\right.$ used in place of $\left.\mathrm{PEt}_{3}\right)$ were carried out by Prof. Sharp and the theoretical enthalpy and free energy changes were calculated. The M06 functional gave values close to that of the experimental. ${ }^{30}$ The results are shown in Table 2.10.1.

Table 2.10.1. Thermodynamic values (kcal/mol) for the bromination of $\mathbf{1}$ and $\mathbf{1},{ }^{30}$

\begin{tabular}{|c|c|c|c|c|}
\hline $\mathrm{R}$ & $\begin{array}{l}\Delta \mathrm{H} \\
\operatorname{Exp}^{\mathrm{a}}\end{array}$ & $\mathrm{B}^{2} \mathrm{LYP} \mathrm{P}^{\mathrm{b}}$ & $\mathrm{M}^{\mathrm{b}}{ }^{\mathrm{b}}$ & $\begin{array}{l}\Delta \mathrm{G} \\
{\mathrm{M} 06^{\mathrm{b}}}^{2}\end{array}$ \\
\hline $\mathrm{Ph}$ & $-38.3 \pm 1.5$ & -20.7 & -32.5 & -21.8 \\
\hline Nap & $-20.5 \pm 1.5^{\mathrm{c}}$ & -10.6 & -23.6 & -10.5 \\
\hline $\mathrm{CF}_{3} \mathrm{Ph}$ & $-17.5 \pm 2$ & -2.7 & -16.3 & -4.7 \\
\hline $\mathrm{BrMeO}_{2} \mathrm{Ph}$ & - & - & -16.8 & -2.2 \\
\hline $\mathrm{Br}$ & $-20.9 \pm 1$ & -16.2 & -27.4 & -15.3 \\
\hline
\end{tabular}

${ }^{\mathrm{a}}$ Toluene solvent. ${ }^{\mathrm{b}}$ Gas phase for trans-Pt($\left(\mathrm{PMe}_{3}\right)_{2}(\mathrm{R})(\mathrm{Br}) \mathbf{1}^{\prime} \cdot{ }^{\mathrm{c}} \mathrm{R}=\mathrm{BrNap}$, LANL2DZ basis set for $\mathrm{Br}, \mathrm{P}$ and $\mathrm{Pt}$ (an added d function), 6-31G(d) basis set for all other atoms. 


\subsection{Structures}

Using single crystal X-ray diffraction studies by Dr. Charles Barnes the solid-state structures of $2\left(\mathrm{Br}, \mathrm{BrNPh}, \mathrm{BrMeO}_{2} \mathrm{Ph}, \mathrm{BrNap}, \mathrm{BriPrOPh}, \mathrm{DiBrPt}\right.$, depe) were determined. 2(BrNap), 2(DiBrPt), 2(depe), 2(BriPrOPh), $\mathbf{1}\left(\mathrm{CF}_{3} \mathrm{Ph}\right)$ and $\mathbf{1}(\mathrm{DiPt})$ probability ellipsoidal drawings are shown in Figures 2.11.1-2.11.6, respectively. The effect of peri-hydrogen $(\mathrm{R}=\mathrm{BrNap})$ or a vicinal substituent on the aryl ring $(\mathrm{R}=\mathrm{BrNPh}$, $\mathrm{DiBrPt}, \mathrm{BrMeO}_{2} \mathrm{Ph}, \mathrm{BriPrOPh}$ ) leads to steric crowding at the platinum center and can be seen in the crystal structures. The $\mathrm{Br}$ and $\mathrm{PEt}_{3}$ ligands cis to the aryl group are sterically hindered. The aryl group tilts about $45^{\circ}$ with regards to the P-Pt-P axis. In this way the peri-hydrogen or the vicinal substituent on the aryl ring is nestled between a cis bromo and a $\mathrm{PEt}_{3}$ ligand. The effect of sterics is clearly visible in the metrical parameters listed in Table 2.11.1. The probability ellipsoid drawing for 2 (BrNap) is shown in Figure 2.11.1. The Pt1-C1-C4 angle is $173^{\circ}$ and not linear. Similarly the Pt1-C1-C9 and Pt1-C1$\mathrm{C} 2$ are $127^{\circ}$ and $116^{\circ}$, respectively, and deviant from the expected $120^{\circ}$ for a $\mathrm{sp}^{2}$ carbon. The peri-hydrogen on $\mathrm{C} 8$ introduces this strain and the Pt1-C1-C9 angle is larger than the Pt1-C1-C2. These steric interactions are also seen at the octahedral platinum(IV) center. The $\mathrm{C} 1-\mathrm{Pt1}-\mathrm{Br} 3$ and $\mathrm{C} 1-\mathrm{Pt1}-\mathrm{P} 2$ angles are $95^{\circ} . \mathrm{Br} 3$ and $\mathrm{P} 2$ are $c i s$ with regards to the aryl ring. Correspondingly, the $\mathrm{C} 1-\mathrm{Pt} 1-\mathrm{Br} 2$ and $\mathrm{C} 1-\mathrm{Pt} 1-\mathrm{P} 1$ are $89^{\circ}$ and as expected. 


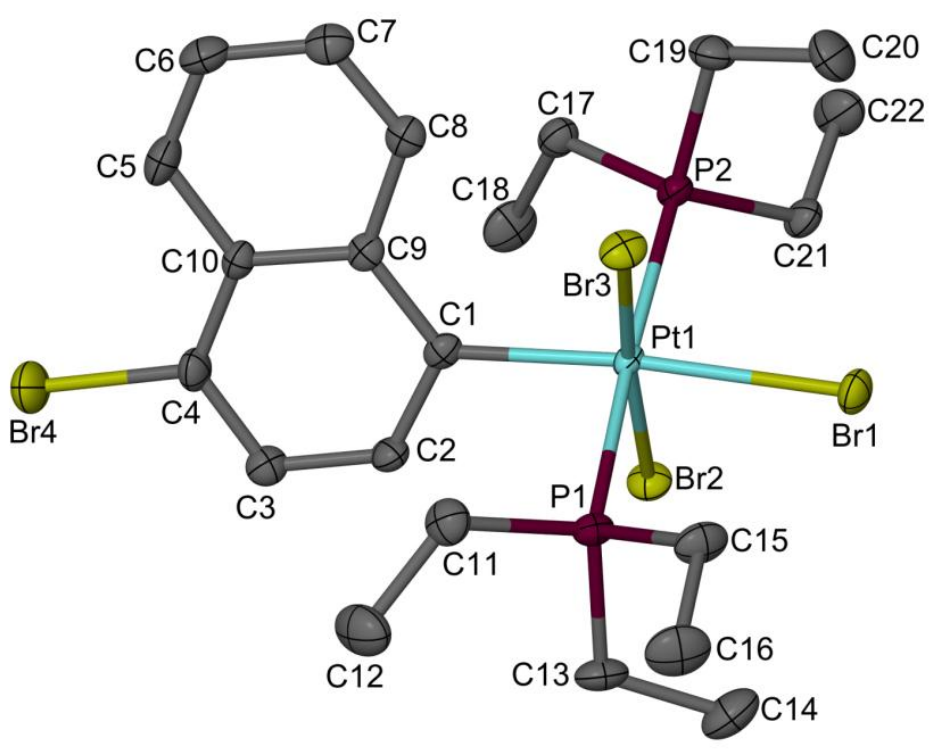

Figure 2.11.1. XSeed/POV-Ray drawing of 2(BrNap). Hydrogen atoms omitted. Atoms are drawn as $50 \%$ probability ellipsoids. ${ }^{30}$

The probability ellipsoid drawing for $\mathbf{2}(\mathrm{DiBrPt})$ is shown in Figure 2.11.2. The 2(DiBrPt) also show the above mentioned steric effects. The napthalenyl ring lies between the P-Pt$\mathrm{P}$ and $\mathrm{Br}-\mathrm{Pt}-\mathrm{Br}$ planes. The $\mathrm{PEt}_{3}$ and bromo ligands on either platinum are in the anticonformation with regards to each other. 


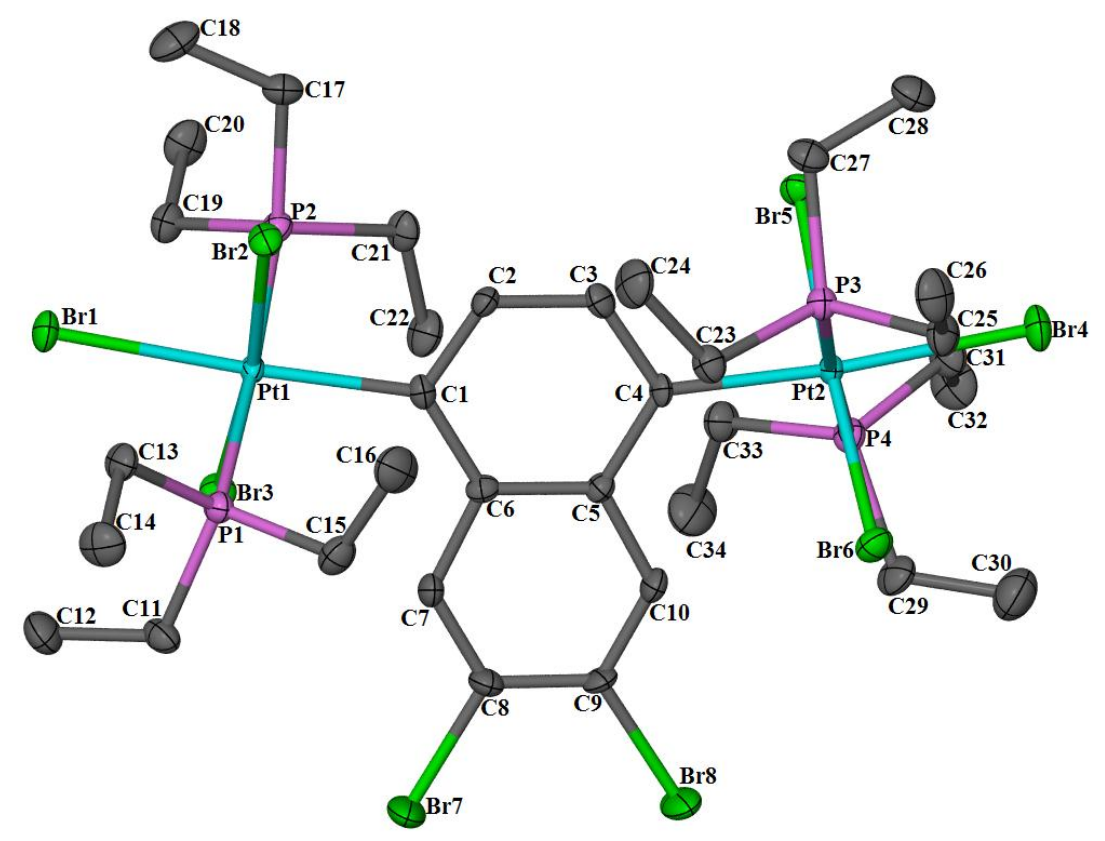

Figure 2.11.2. XSeed/POV-Ray drawing of 2(DiBrPt). Hydrogen atoms omitted. Atoms are drawn as $50 \%$ probability ellipsoids. 


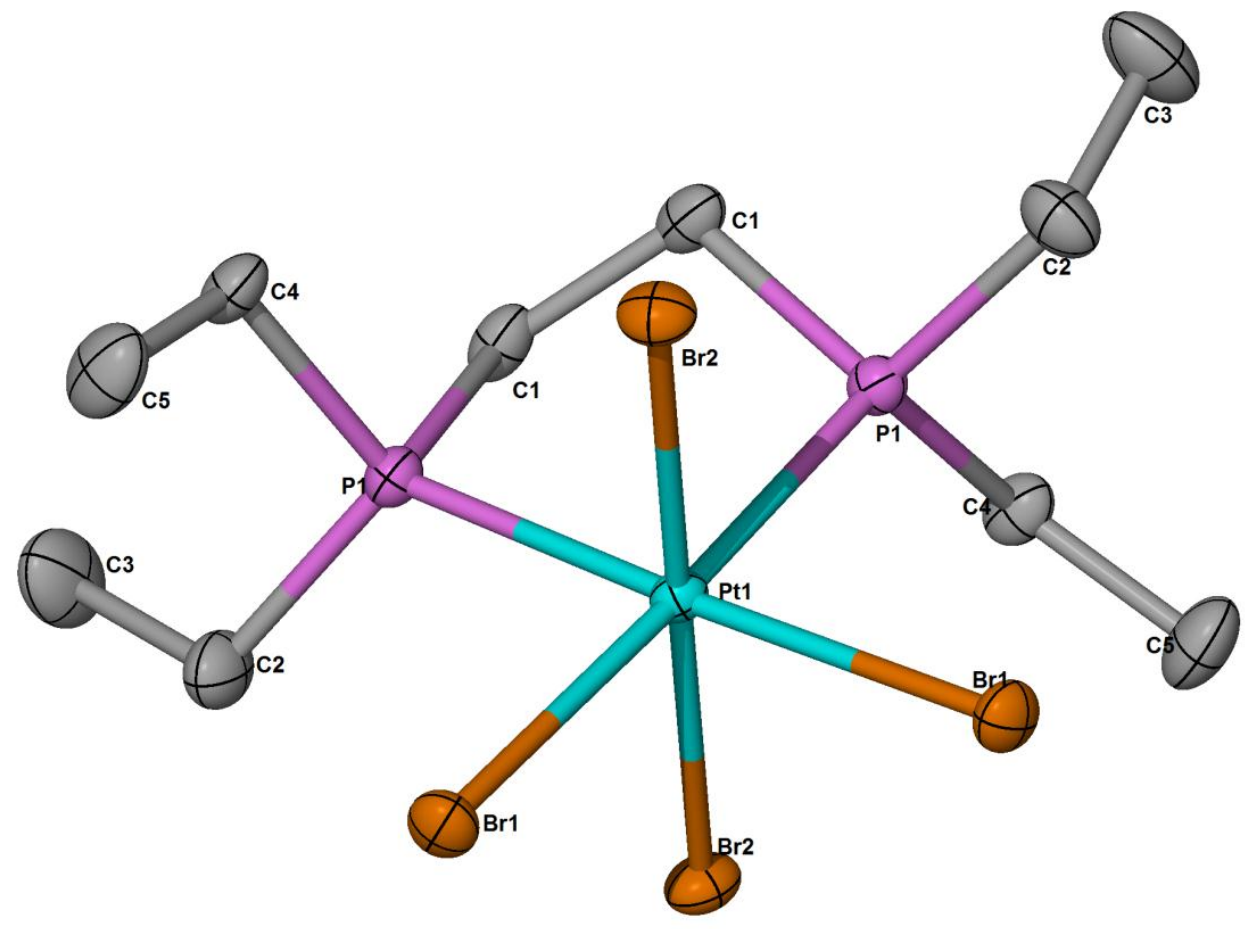

Figure 2.11.3. XSeed/POV-Ray drawing of 2(depe). Hydrogen atoms omitted. Atoms are drawn as $50 \%$ probability ellipsoids.

In the case of $2\left(\mathrm{BrMeO}_{2} \mathrm{Ph}\right)$ shown in Figure 2.11.4 with vicinal substituents on both sides of the aryl ring the steric strain is felt on all four (P1, $\mathrm{P} 2, \mathrm{Br} 2$ and $\mathrm{Br} 3)$ ligands. More deviation is seen with regards to the $\mathrm{PEt}_{3}$ ligands though. The probability ellipsoid drawing for $2(\mathrm{BriPrOPh})$ is shown in figure 2.11.4. The $2(\mathrm{BriPrOPh})$ parameters are similar to 2(BrNap). In the case of 2-phenanthrenyl and 2-perylenyl platinum(IV) 
analogues and DFT structures of the $\mathrm{PMe}_{3}$ analogue 2' calculated by Prof. Sharp also such steric effects were seen. ${ }^{30}$

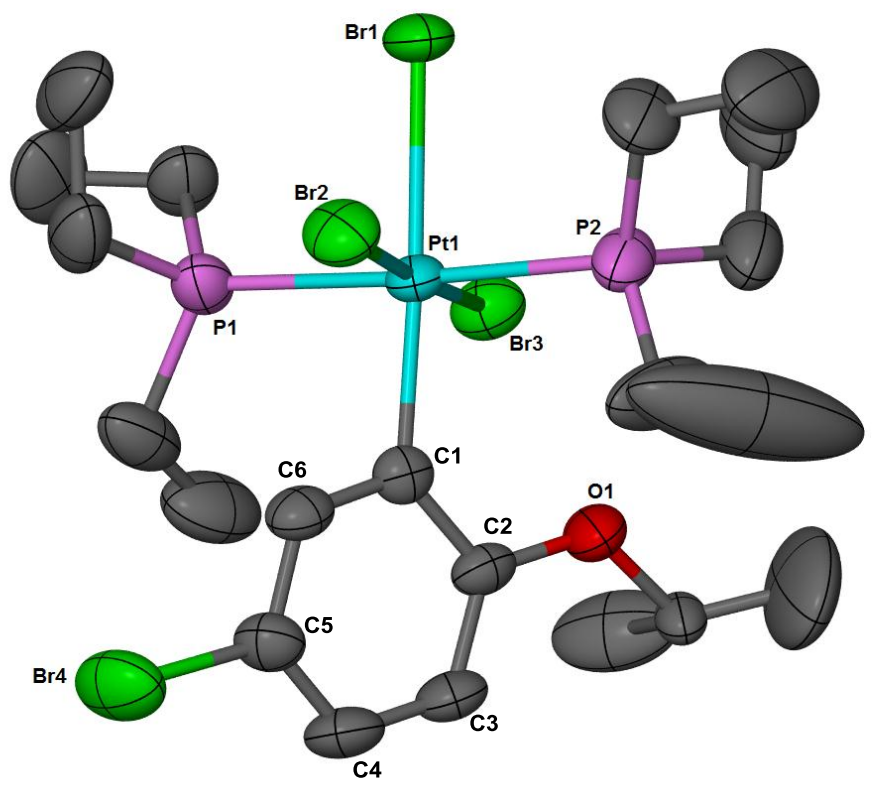

Figure 2.11.4. XSeed/POV-Ray drawing of 2(BriPrOPh). Hydrogen atoms omitted. Atoms are drawn as $50 \%$ probability ellipsoids.

Using single crystal X-ray diffraction studies by Dr. Barnes the solid-state structures of $\mathbf{1}\left(\mathrm{CF}_{3} \mathrm{Ph}, \mathrm{NPh}, \mathrm{MeO}_{2} \mathrm{Ph}, \mathrm{BrMeO}_{2} \mathrm{Ph}, \mathrm{DiPt}\right)$ were also obtained. The aryl ring plane lies between the two trans- $\mathrm{PEt}_{3}$ ligands. The peri-hydrogen or vicinal substituents influence the parameters of the ligand cis to them. $\mathbf{1}\left(\mathrm{CF}_{3} \mathrm{Ph}\right)$ structure is interesting and shown in Figure 2.11.5. The Pt1 nestles between two of the $\mathrm{CF}_{3}$ fluorine atoms. Hence the P-Pt-P angle on the $\mathrm{CF}_{3}$ side is close to $188^{\circ}$ and bent. The $1(\mathrm{DiPt})$ structure is shown in figure 2.11.6. 


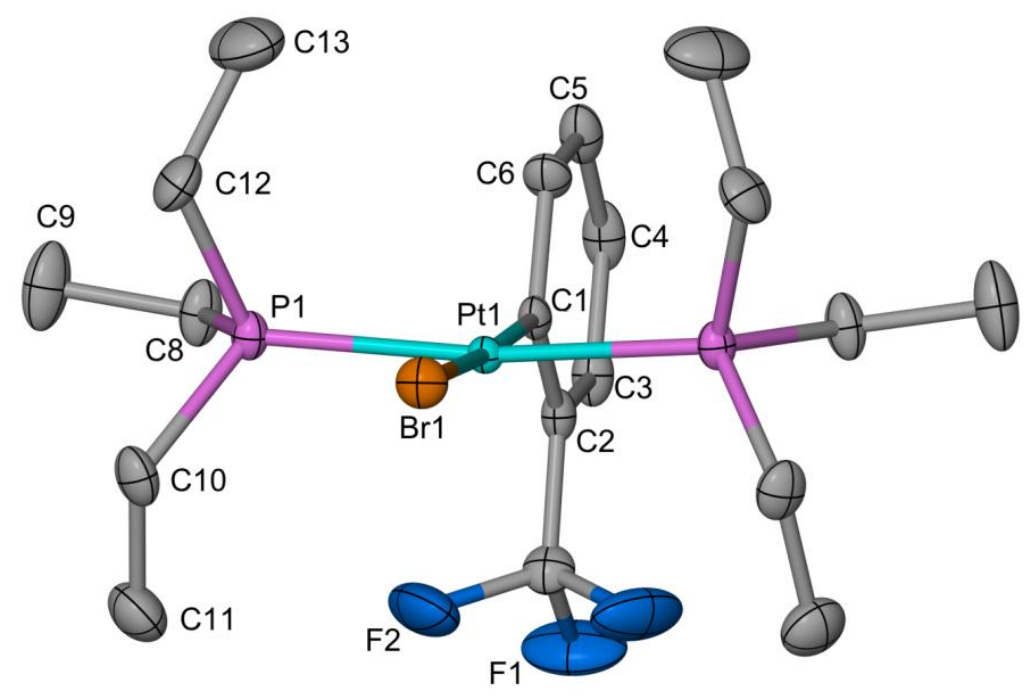

Figure 2.11.5. XSeed/POV-Ray drawing of $1\left(\mathrm{CF}_{3} \mathrm{Ph}\right)$. Hydrogen atoms omitted. Atoms are drawn as $50 \%$ probability ellipsoids. ${ }^{30}$ 


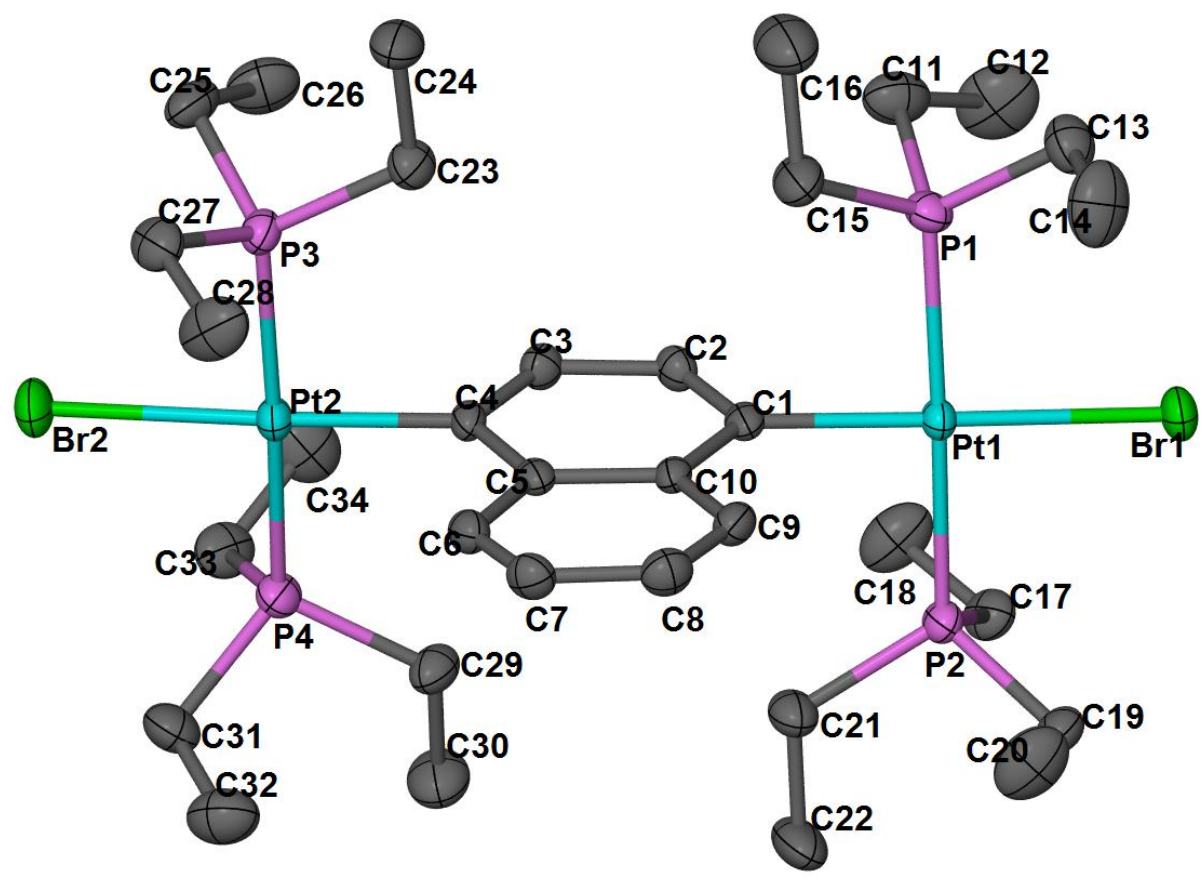

Figure 2.11.6. XSeed/POV-Ray drawing of 1(DiPt). Hydrogen atoms omitted. Atoms are drawn as $50 \%$ probability ellipsoids.

Table 2.11.1. Metrical parameters for $2\left(\mathrm{R}=\mathrm{BrNap},{ }^{\mathrm{b}} \mathrm{BrMeO}_{2} \mathrm{Ph},{ }^{\mathrm{b}} \mathrm{BriPrOPh}, \mathrm{DiBrPt}\right)$.

\begin{tabular}{|c|c|c|c|c|}
\hline Atoms $^{a}$ & 2(BrNap) & $2\left(\mathrm{BrMeO}_{2} \mathrm{Ph}\right)$ & 2(BriPrOPh) & 2(DiBrPt) \\
\hline Pt1-C1 & $2.107(5)$ & $2.104(2)$ & $2.105(6)$ & $2.104(3)$ \\
\hline Pt1-C1-C4 & $172.8(4)$ & $177.3(2)$ & 170.07 & 171.54 \\
\hline Pt1-C1-C2 & $115.9(4)$ & $121.9(2)$ & $115.7(4)$ & $116.8(2)$ \\
\hline Pt1-C1-C9 & $127.4(4)$ & $121.4(2)$ & $126.1(4)$ & $128.1(2)$ \\
\hline C1-Pt1-P1 & 88.24(14) & $93.72(6)$ & $89.21(15)$ & $89.06(9)$ \\
\hline C1-Pt1-P2 & 94.93(14) & $93.34(6)$ & $93.86(15)$ & $93.71(9)$ \\
\hline C1-Pt1-Br2 & $89.38(14)$ & $90.91(6)$ & $89.95(15)$ & $90.39(9)$ \\
\hline C1-Pt1-Br3 & $95.10(14)$ & $89.55(6)$ & $93.69(15)$ & $96.01(9)$ \\
\hline
\end{tabular}

${ }^{\mathrm{a}}$ Numbering from 2(BrNap). Corresponding atoms in other structures may have different numbers. ${ }^{\mathrm{b}}$ Ref 30. 


\section{CHAPTER 3: DISCUSSION}

\subsection{Effect of sterics on photochemistry}

Initially, halogen photoelimination from organoplatinum(IV) centers was investigated using sterically encumbered aryl ligands to probe the effects of sterics at the metal center. The idea was that steric bulk adjacent to the metal center spring loads the complex for $\mathrm{Br}_{2}$ photoelimination. In complex $2(\mathrm{BrNap})$ the peri-hydrogen is nestled between the bromo and phosphine ligand as shown in Scheme 3.1.1. In complexes $2\left(\mathrm{CF}_{3} \mathrm{Ph}, \mathrm{BrNPh}\right.$, $\mathrm{BrMeO}_{2} \mathrm{Ph}$, and $\mathrm{BriPrOPh}$ ) also the vicinal subsituent exercises steric effects similar to the peri-hydrogen. The solid-state X-ray structure and DFT calculations support steric interaction between the peri-hydrogen and the bromo ligand. ${ }^{37}$ Thus, the initial inference was in complexes $\mathbf{2}$ halogen elimination can be turned on or off based on sterics. ${ }^{30}$

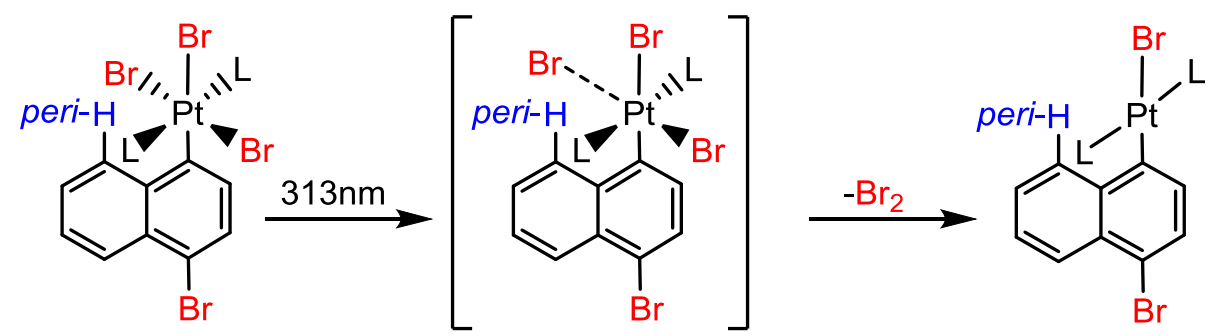

Scheme 3.1.1. Peri-hydrogen sterics.

From literature we know that the peri-hydrogen atoms protect 1-naphthalenyl and 2anthracenyl platinum(II) centers from $\mathrm{Br}_{2}$ addition. ${ }^{29},{ }^{45}$ Previously our group had 
reported novel polybromoanthracenes by addition of excess $\mathrm{Br}_{2}$ to an anthracenyl platinum(II) complex as shown in Scheme 3.1.2. ${ }^{45}$ Addition of bromine was not seen at the platinum center even with huge excess of $\mathrm{Br}_{2}$. This was attributed to peri-hydrogen sterics.
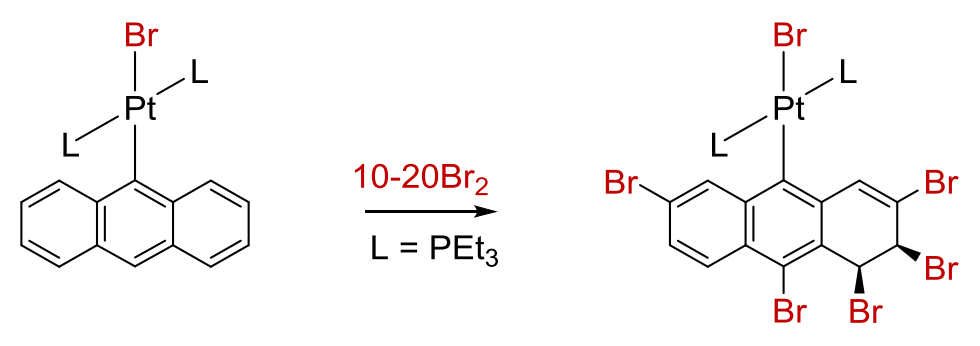

Scheme 3.1.2. peri-hydrogen sterics in platinum(II) anthracenyl complex.

Correspondingly, the 1-phenyl and 2-napthyl (2(2-Nap)) platinum(IV) complexes with no peri-hydrogen and vicinal substituents are nearly photoinactive. Also, it is known in aryl systems, the photoexcited state can be deactivated by rotation of the aryl ring. ${ }^{55,56}$ Thus, if sterics prevent the facile rotation of the aryl ring, then deactivation of the excited state decreases, correspondingly, showing increase in the efficiency for the photoelimination process. Complex $2\left(\mathrm{CF}_{3} \mathrm{Ph}\right)$ agrees with this trend and shows a very high quantum yield of $82 \%$. Interestingly $2(\mathrm{Br})$ shows a very high quantum yield of $59 \%$ for $\mathrm{Br}_{2}$ photoelimination. This complex is relatively unhindered. Also the absence of the aryl ring in $\mathbf{2}(\mathrm{Br})$ decreases the deactivation pathways possible through facile rotation. Population, lifetime and decay of the excited state should be factors which should be explored in understanding the photoelimination process. 
Hence, with regards to understanding the quantum yield measurements, no specific trends are observed. As discussed above sterics seem to play a role and is one of the aspects to be considered. 2(1-Nap), 2(BrNap) and 2(Phen) show good quantum efficiencies of 13\%, $19 \%$ and $13 \%$, respectively. Correlating this to reaction free energies obtained from calorimetry and DFT calculations also does not show any specific trends. ${ }^{30}$ Again the 2(Br) with a high free energy change of $21 \mathrm{kcal} / \mathrm{mol}$ shows a very high quantum yield of $59 \%{ }^{30}$ Hence, to consider the trends with regards to one specific aspect is not sufficient. Effects of sterics, electronics and photochemical deactivation pathways should be thoroughly explored.

\subsection{Thermochemistry}

Steric affects the thermochemistry of $\mathrm{Br}_{2}$ addition to platinum(II) centers as well. Based on DFT calculations (by Prof. Sharp), calorimetry measurements (by Prof. Hoff) and X-

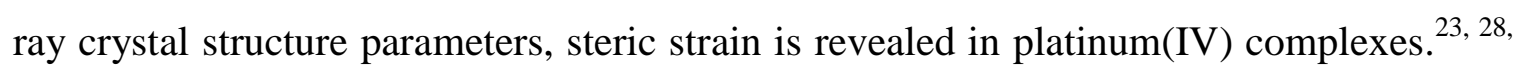
${ }^{30}$ Correspondingly in the square planar platinum(II) complexes these effects are absent. Based on the DFT and calorimetry calculations, the $2\left(\mathrm{CF}_{3} \mathrm{Ph}\right)$ complex shows the least stability for $\mathrm{Br}_{2}$ elimination thermally. $\mathbf{2}\left(\mathrm{CF}_{3} \mathrm{Ph}\right)$ converts to $\mathbf{1}\left(\mathrm{CF}_{3} \mathrm{Ph}\right)$ at room temperature in the solution and solid state. A first and zero order dependence in $2\left(\mathrm{CF}_{3} \mathrm{Ph}\right)$ and 1-hexene is seen respectively. A possible thermal $\mathrm{Br}_{2}$ elimination mechanism for $2\left(\mathrm{CF}_{3} \mathrm{Ph}\right)$ is shown in Scheme 3.2.1 The $\mathrm{k}_{\mathrm{obs}}$ is $1.4(2) \times 10^{-3} \mathrm{~min}^{-1}$ based on the kinetic measurement is comparable to the $\mathrm{k}_{\mathrm{re}}$. Based on the DFT calculations the free energy 
change associated with the $\mathrm{Br}_{2}$ addition to $2\left(\mathrm{CF}_{3} \mathrm{Ph}\right)$ is $\sim 5 \mathrm{kcal}$. Correspondingly the $\mathrm{k}_{\mathrm{ox}}$ value should be at least $10 \mathrm{~min}^{-1} \mathrm{M}^{-1}$.
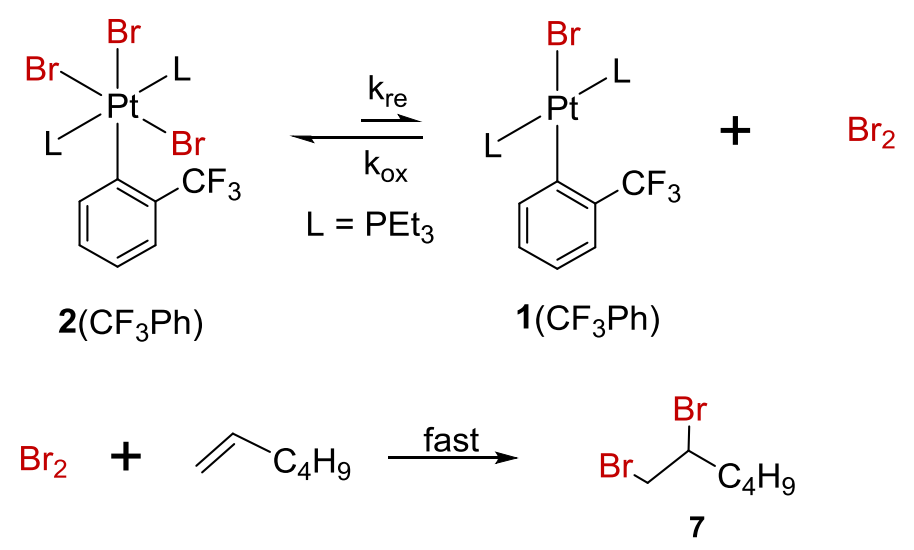

Scheme 3.2.1 Thermal $\mathrm{Br}_{2}$ elimination mechanism for $2\left(\mathrm{CF}_{3} \mathrm{Ph}\right)$.

The $\mathbf{2}$ (BrNap) converts to $\mathbf{1}(\mathrm{BrNap})$ at $325 \mathrm{~K}$ in the solution state. The possible thermal $\mathrm{Br}_{2}$ elimination mechanism for 2(BrNap) is shown in Scheme 3.2.2. A first order dependence in $\mathbf{2}$ (BrNap) is observed. Based on the above $2\left(\mathrm{CF}_{3} \mathrm{Ph}\right)$ kinetics for $\mathrm{Br}_{2}$ elimination a zero order dependence with 1-hexene for $\mathbf{2}$ (BrNap) is also assumed. $\mathrm{k}_{\mathrm{obs}}$ is comparable to $\mathrm{k}_{\mathrm{re}}$ and a value of $9( \pm 1) \times 10^{-4} \mathrm{~min}^{-1}$ was obtained. Based on the DFT calculations the free energy associated with thermal $\mathrm{Br}_{2}$ elimination from 2(1-Nap) is $11 \mathrm{kcal}^{30}$ This should be comparable to 2(BrNap) free energy change. Hence, the $\mathrm{k}_{\mathrm{ox}}$ value should be at least $2 \times 10^{4} \mathrm{~min}^{-1} \mathrm{M}^{-1}$ at $325 \mathrm{~K}$. Based on these $\mathrm{k}_{\mathrm{ox}}$ values of $2\left(\mathrm{CF}_{3} \mathrm{Ph}\right)$ and 2 (BrNap), the rate of $\mathrm{Br}_{2}$ addition to platinum(II) complexes seems very fast. 
<smiles>Brc1ccc(P(Br)(Br)(Br)I)c2ccccc12</smiles>

2(BrNap)

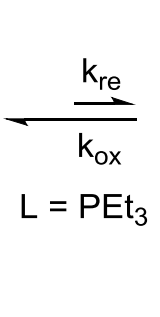<smiles>Brc1ccc([P](Br)(I)I)c2ccccc12</smiles>

1(BrNap)
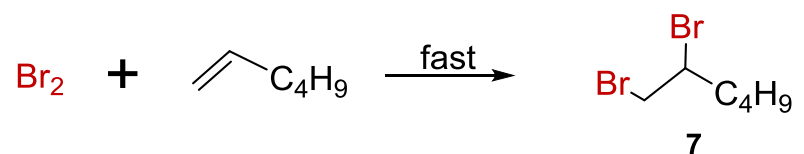

Scheme 3.2.2. Thermal $\mathrm{Br}_{2}$ elimination mechanism for 2 (BrNap).

Electronic factors also affect the thermochemistry of our platinum(II) complexes. Looking at the free energy change associated with the bromination of $\mathbf{1}(\mathrm{Br})$ and $\mathbf{1}(\mathrm{Ph})$, we see that the $\mathbf{1}(\mathrm{Ph})$ free energy change is more negative. Possibly the phenyl ligand is more electron donating in $\mathbf{1}(\mathrm{Ph})$ compared to the bromo ligand in $\mathbf{1}(\mathrm{Br}){ }^{30}$

\section{3 $\mathrm{Br}_{2}$ addition to platinum(II) versus alkene comparison}

Based on literature and experimental results the alkene versus platinum(II) $\mathrm{Br}_{2}$ addition rates were compared. At low $\mathrm{Br}_{2}$ concentrations $\left(<10^{-3} \mathrm{M}\right)$ and absence of bromide ions, the bromination rate expression is second order. ${ }^{57}$ It is first order with both alkene and $\mathrm{Br}_{2}$. Further, at high alkene concentrations the rate law is reduced to first order as shown in Scheme 3.3.1. From literature the second order rate constant for 1-hexene in $\mathrm{CCl}_{4}$ was $0.015 \mathrm{~min}^{-1} \mathrm{M}^{-1} \cdot{ }^{58}$ For 1 -pentene in acetic acid it was found to be $990( \pm 12) \mathrm{min}^{-1} \mathrm{M}^{-1} \cdot{ }^{57} \mathrm{In}$ the case of cyclohexene the second order rate constant was $684(13) \mathrm{min}^{-1} \mathrm{M}^{-1}$ in $\mathrm{CDCl}_{3}{ }^{59}$ 


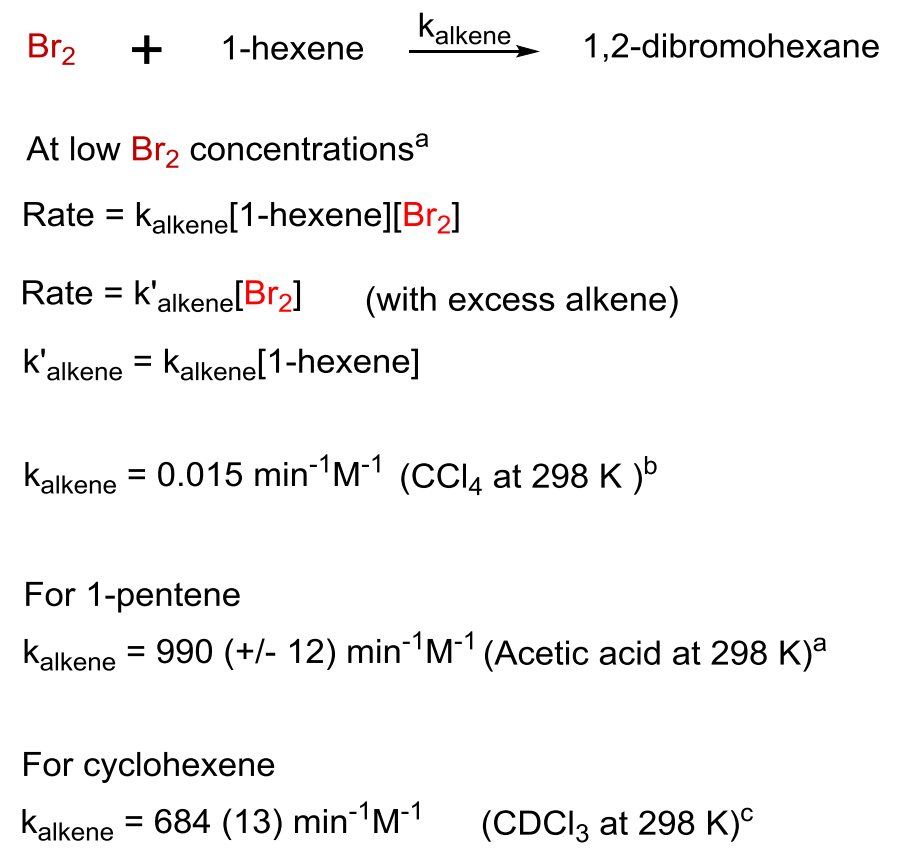

Scheme 3.3.1. $\mathrm{Br}_{2}$ addition to alkene rates. ${ }^{\mathrm{a}} \operatorname{Ref} 57,{ }^{\mathrm{b}} \operatorname{Ref} 58,{ }^{\mathrm{c}} \operatorname{Ref} 59$

Possible reaction rate expression for $\mathrm{Br}_{2}$ addition to platinum(II) center is shown in Scheme 3.3.2. It is first order in both platinum(II) and $\mathrm{Br}_{2}$. Further, at high platinum(II) concentrations the rate law is reduced to a first order expression. Based on the thermochemistry and kinetic experiments the $\mathrm{k}_{\mathrm{ox}}$ value should be at least $2 \times 10^{4} \mathrm{~min}^{-1} \mathrm{M}^{-}$ ${ }^{1}$ at $325 \mathrm{~K} . \mathrm{k}_{\mathrm{OX}}$ is the same as $\mathrm{k}_{\mathrm{PtII}}$ in Scheme 3.3.2. According to the rate expression and experimental results the platinum(II) bromination rate is at least ten times greater than alkene bromination rate. 


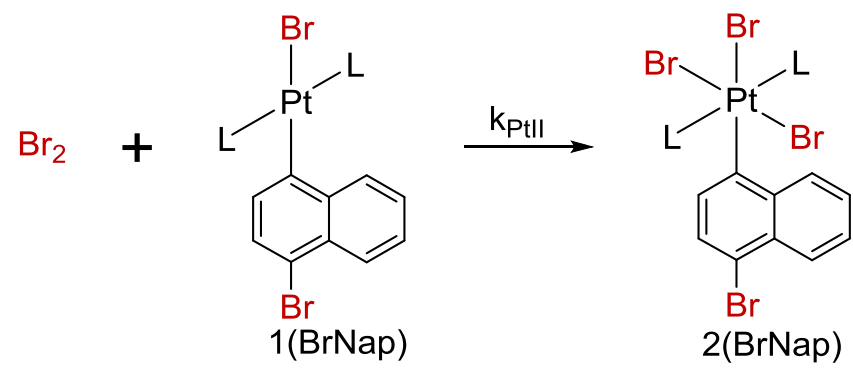

$$
\begin{aligned}
& \text { At low }\left[\mathrm{Br}_{2}\right] \\
& \text { Rate }=\mathrm{k}_{\mathrm{PtII}}^{\prime}\left[\mathrm{Br}_{2}\right] \quad \text { (with excess PtII) } \\
& \mathrm{k}_{\mathrm{PtIl}}^{\prime}=\mathrm{k}_{\mathrm{PtII}}[\mathrm{PtII}] \\
& \text { Rate }=\mathrm{k}_{\mathrm{PtII}}[\mathrm{PtII}]\left[\mathrm{Br}_{2}\right] \\
& \mathrm{k}_{\mathrm{PtII}} \sim 2 \times 10^{4} \mathrm{~min}^{-1} \mathrm{M}^{-1} \text { at } 325 \mathrm{~K} \\
& \mathrm{k}_{\mathrm{PtII}}>10 \mathrm{k}_{\text {alkene }}
\end{aligned}
$$

Scheme 3.3.2. $\mathrm{Br}_{2}$ addition to platinum(II).

\subsection{Photochemical pathways}

A simplified Jablonski diagram is shown in Scheme 3.4.1 to understand the various photoexcited pathways. ${ }^{30}$ The strong $\pi-\pi^{*}$ singlet state transition $\left(S_{0} \rightarrow S_{\mathrm{x}}\right)$ is significant in the case of organoplatinum (IV) complexes coordinated to aryl ligands. For $2(\mathrm{Br})$ with a bromo and phosphine ligand framework there are no $\pi$ - $\pi^{*}$ transitions. Further at $313 \mathrm{~nm}$ and $380 \mathrm{~nm}$ (absorption at the tail end in the uv-vis spectrum) 2(BrNap) undergoes facile $\mathrm{Br}_{2}$ photoelimination. This suggests that from a lower energy singlet excited state $\mathrm{S}_{1}$ intersystem crossing (ISC) happens into the triplet $\left(\mathrm{T}_{1}\right)$ state. $\mathrm{S}_{1}$ is probably the $\mathrm{Br}-\mathrm{Pt}$ LMCT excited state involving the $n-\sigma *$ transition where bromine lone pairs get excited to the $\sigma *$ orbital on the metal center. Based on DFT calculations in our group for $\mathrm{Br}_{2}, \mathrm{Cl}_{2}$ and $\mathrm{HOCl}$ eliminations we see that $\mathrm{T}_{1}$ is the lowest energy state from which the various 
photochemical reaction pathways are accessed. The triplet excited state also has more radical character. ${ }^{37,38}$ The triplet platinum excited state can be trapped by solvents and traps (cis-2-hexene, 1-hexene and TME). Self-trapping generates ring brominated products. The population of the $T_{1}$ state is crucial with regards to the the quantum yield. The various processes affecting it are fluorescence $\left(\mathrm{k}_{\mathrm{fx}}\right.$ of $\pi-\pi^{*}$ and $\mathrm{k}_{\mathrm{f} 1}$ of $\left.n-\sigma *\right)$, phosphorescence $\left(\mathrm{k}_{\mathrm{p}}\right)$ and non-radiative decay. Non-radiative decay rates $\mathrm{k}_{\mathrm{nrs} 1}, \mathrm{k}_{\mathrm{nrsx}}$, and $\mathrm{k}_{\mathrm{nrt}}$ relating to $\mathrm{S}_{1} \rightarrow \mathrm{S}_{0}, \mathrm{~S}_{\mathrm{x}} \rightarrow \mathrm{S}_{1}$, and $\mathrm{T}_{1} \rightarrow \mathrm{S}_{0}$ transitions, respectively, also compete with the radiative decay pathways.

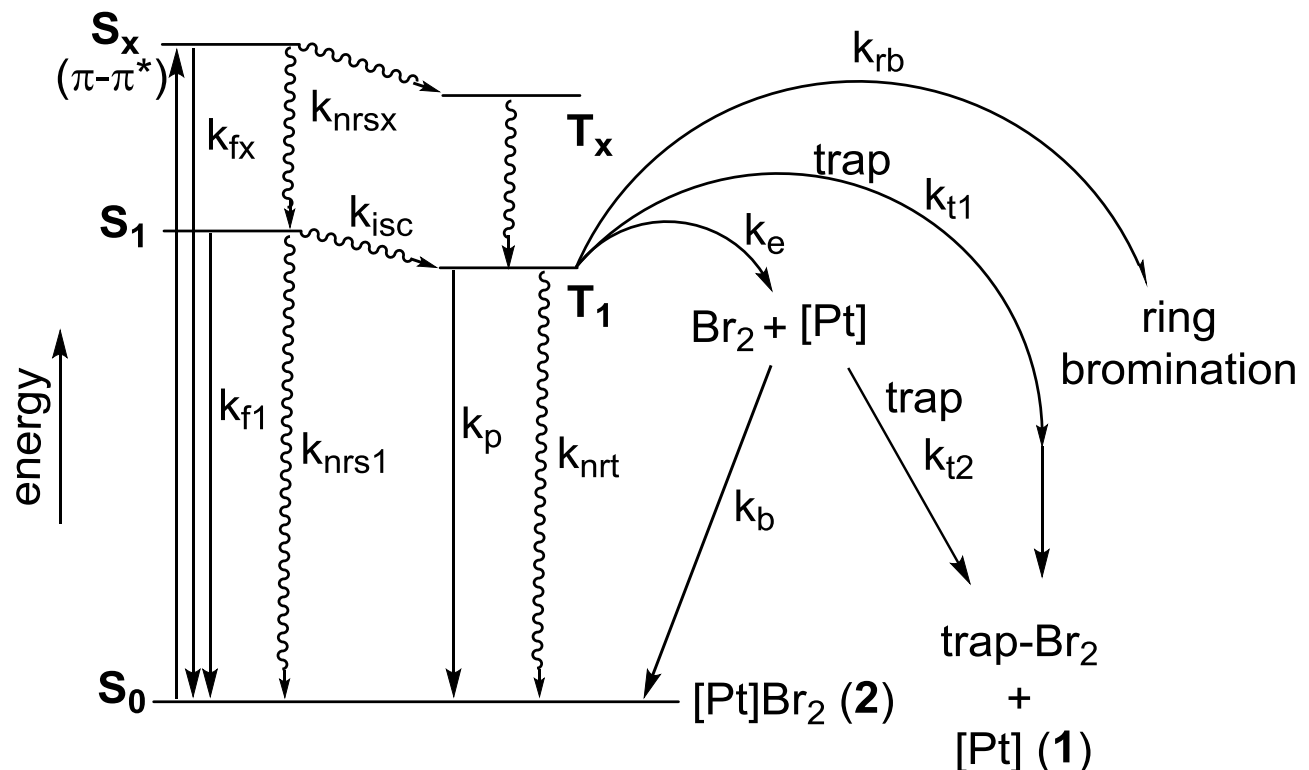

Scheme 3.4.1. Photoexcited pathways. 
Photoelimination kinetic studies and investigation of the trap reaction products gives us insights with regards to net $\mathrm{Br}_{2}$ photoelimination from our platinum(IV) complexes. Our results support $\mathrm{Br}_{2}$ elimination as well as an excited state radical pathway. With less reactive traps like cis-2-hexene anti-bromination product is observed. Addition of $\mathrm{Br}_{2}$ to alkene proceeds through a cyclic bromonium ion mechanism and anti-products are favored. ${ }^{60-62}$ The mixed alkene bromination competition experiment also support elimination of molecular bromine $\left(\mathrm{Br}_{2}\right)$, whilst photolysis of 2 (BrNap). Only 3,4-transdibromohexane addition product is observed on photolysis of 2(BrNap) with excess 1:1 mixture of trans-3-hexene and 1-hexene . 1,2-dibromohexane, the 1-hexene addition product is not seen. This result is in agreement with molecular $\mathrm{Br}_{2}$ addition to excess $1: 1$ mixture of trans-3-hexene and 1-hexene. This also showed only the 3,4-transdibromohexane and no 1,2-dibromohexane is observed. Hence, the competition experiment suggests that the brominating agent is molecular bromine $\left(\mathrm{Br}_{2}\right)$.

Further the kinetic studies on 2 (BrNap) photoelimination in the presence and absence of 1(BrNap) gave important insights. A decrease in $\mathbf{2}$ (BrNap) photolysis rate is observed when a 1:1 mixture of $\mathbf{2}(\mathrm{BrNap}): \mathbf{1}(\mathrm{BrNap})$ is photolysed at $380 \mathrm{~nm}$ with 1-hexene. Thus, the product $\mathbf{1}(\mathrm{BrNap})$ is competing with the alkene for the photoeliminated $\mathrm{Br}_{2} . \mathbf{1}(\mathrm{BrNap})$ combines with $\mathrm{Br}_{2}$ very quickly to form 2(BrNap) decreasing the rate. Hence, there is support for $\mathrm{Br}_{2}$ photoelimination from platinum(IV) centers based on these results. 


\subsection{Excited state platinum precursor}

In the presence of a reactive trap like TME the alkene product profile is different in comparison to a less reactive alkene like 1-hexene. TME along with the bromine addition product yields alkene products which can only be accessed through the radical pathway. An increase in the trap concentration thus should increase the radical pathway products. With higher trap concentrations, the probability of trap molecules reacting with the excited state is higher. There was one exception seen, though. In the case of a perylene based $\sigma$-bonded platinum(IV) complex prepared by Dr. Masjedi, only the $\mathrm{Br}_{2}$ addition product was observed even with a reactive trap like TME. The platinum excited state quickly eliminates $\mathrm{Br}_{2}$ in comparison to the radical pathway. Also the radical excited

state character could be more delocalized because of the ligand system. ${ }^{30}$ Hence, Scheme 3.5.1 is given rationalizing the reactivity of the excited state platinum center with reactive and not so reactive traps. ${ }^{30}$
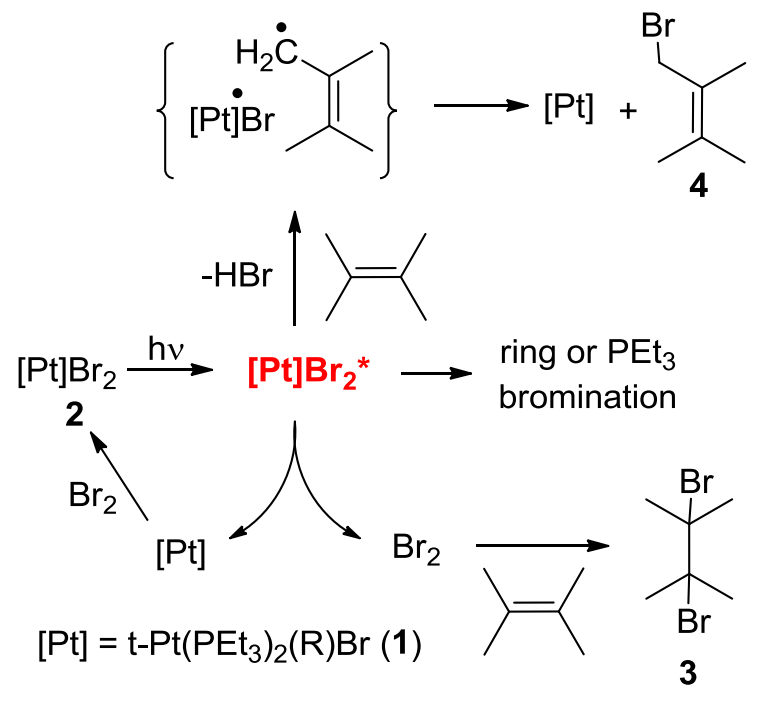

Scheme 3.5.1 Reactivity of platinum excited state. 


\subsection{Bromo anion, bromo radical versus $\mathrm{Br}_{2}$ elimination}

To understand our system we looked at the $\left[\mathrm{PtBr}_{6}\right]^{2-}$ photochemistry. The Tarnovsky group using transient absorption spectroscopy measurements and computational modelling, had reported initial displacement of a bromo ligand to form $\left[\mathrm{Pt}\left(\mathrm{H}_{2} \mathrm{O}\right) \mathrm{Br}_{5}\right]^{1-}$ in aqueous solutions. ${ }^{63}$ Previously also bromine anion, ${ }^{64,} 65$ bromine atom ${ }^{66}$ and $\mathrm{Br}_{2}{ }^{67}$ eliminations were reported in the literature. Depending on the reaction conditions there have been reports of a radical like excited state platinum species. ${ }^{68,69}$ Our platinum(IV) complexes are neutral species with non-aqueous solubility behavior. Hence, direct comparison to $\left[\mathrm{PtBr}_{6}\right]^{2-}$ is not feasible. Also phosphines and strong $\sigma$-donor aryl ligands add to the variation of the ligand environment at the platinum center. Hence $\mathrm{CH}_{2} \mathrm{Cl}_{2}$ soluble $\left[\mathrm{NBu}_{4}\right]_{2}\left[\mathrm{PtBr}_{6}\right]$ was synthesized by our group member Andreas Ross and its photochemistry was studied. ${ }^{30}$ It showed evidence for bromo ligand dissociation just like in $\left[\mathrm{PtBr}_{6}\right]^{2-}$. Hence, the corresponding differences in our platinum complexes behavior and $\left[\mathrm{PtBr}_{6}\right]^{2-}$ maybe based on charge or the variation in ligand environment. Bromo ligand dissociation is favored from an anionic $\left[\mathrm{PtBr}_{6}\right]^{2-}$ species versus our neutral platinum complexes. In the case of $\left[\mathrm{PtBr}_{6}\right]^{2-}$ the lowest energy triplet state is a metal centered, ligand field ${ }^{3} \mathrm{~T}_{1 \mathrm{~g}}$ state with close lying Br-to-Pt charge transfer state ${ }^{63,70}$ Based on DFT calculations by Dr. Sharp we see that the lowest energy triplet state is a charge transfer excited state with bromine radical character. This directs us to the Br-to-Pt charge transfer state (LMCT) as the lowest energy triplet in our complexes. $\mathrm{The} \mathrm{Br}_{2}$ elimination proceeds from this triplet state. 


\section{7 cis photoelimination}

Some additional insights of the photochemical process were gained from other group member's work. From studies done by Tharushi Perera and Lasantha Wickramasinghe, we see evidence for the photoelimination process to happen in the cis rather than the trans fashion. ${ }^{37}$ This might have implications if the ligand coordination environment is too rigid around the metal center with regards to halogen photoelimination. 


\section{CHAPER 4: EXPERIMENTAL SECTION}

\subsection{Materials and General Procedures}

$\mathrm{Pt}\left(\mathrm{PEt}_{3}\right)_{4}{ }^{39}$ cis-Pt($\left(\mathrm{PEt}_{3}\right)_{2}(\mathrm{Cl})_{2}{ }^{71}$ and $1,4-$ dibromonaphthalene, ${ }^{41}$ were prepared by reported procedures. Reagents were purchased from commercial sources (Aldrich or Acros) and used as received. Experiments performed under dinitrogen atmosphere in a Vacuum Atmospheres Corporation drybox or on a Schlenk line are specifically mentioned. Solvents for dinitrogen atmosphere experiments were dried, degassed and stored under dinitrogen over $4 \AA$ molecular sieves or sodium metal. NMR spectra were recorded on Bruker AMX-250, -300, or -500 spectrometers at ambient probe temperatures except as noted. NMR shifts are given in $\delta$ with positive values downfield of TMS $\left({ }^{1} \mathrm{H}\right.$ and ${ }^{13} \mathrm{C}$ ), external $\mathrm{H}_{3} \mathrm{PO}_{4}\left({ }^{31} \mathrm{P}\right)$, or external $\mathrm{K}_{2} \mathrm{PtCl}_{4}($ aq $)\left({ }^{195} \mathrm{Pt}, \delta-1630\right) .{ }^{13} \mathrm{C}$ and ${ }^{1} \mathrm{H}$ NMR spectra were recorded in proton-decoupled mode. Peaks assignment was assisted by ${ }^{13} \mathrm{C}$ dept-135 experiments. Desert Analytics performed the microanalyses. Uvvis spectra were recorded on a Cary 50, Cary 100 or Hewlett-Packard 8452 diode array spectrophotometer in quartz cells. Photolysis was performed in quartz (uv or fluorescence) or borosilicate glass vessels using a $500 \mathrm{~W}$ halogen lamp, a $400 \mathrm{~W}$ medium pressure Hg lamp, a Philips PL-S 9W/01, 9 W lamp with a 300-380 $\mathrm{nm}$ band pass filter (313 nm emission), or LED's of the indicated wavelength. Emission spectra were obtained on a Varian Cary Eclipse fluorescence spectrophotometer with $1 \mathrm{~cm}$ path length quartz cells. For low temperature, emission spectra and lifetime were obtained on a Cary Eclipse Fluorescence spectrophotometer with samples in quartz (UV)/NMR tube at $77 \mathrm{~K}$. Photolysis was also performed at $77 \mathrm{~K}$ in a quartz (UV)/NMR tube using LED's. For 380 
nm irradiations, a home built tube photo-reactor was used and consisted of a short section of $4.2 \mathrm{~cm}$ PVC pipe lined with 24 LED's (superbrightleds.com, RL5-UV031 5mm UV LED) connected in series. ${ }^{38}$

\subsection{Syntheses}

trans-Pt $\left(\mathbf{P E t}_{3}\right)_{2}(\mathbf{B r})_{2}$ 1(Br). Yellow-white waxy solid cis- $\mathrm{Pt}\left(\mathrm{PEt}_{3}\right)_{2}(\mathrm{Cl})_{2}(836.3 \mathrm{mg}, 1.665$ mmol) was dissolved in $\mathrm{CH}_{2} \mathrm{Cl}_{2}$ to yield a yellow clear solution. The solution was transferred to a $100 \mathrm{~mL}$ sealable tube and the volatiles were removed in vacuo. Absolute ethanol (10 mL) and finely ground $\mathrm{KBr}(12 \mathrm{~g}, 100 \mathrm{mmol})$ were added to form a cloudy light yellow solution. The tube was sealed and its contents were heated at $100{ }^{\circ} \mathrm{C}$ for $9 \mathrm{~h}$ with constant stirring. Within a few minutes of heating the mixture had changed to a deep yellow clear solution with $\mathrm{KBr} / \mathrm{KCl}$ solid at the bottom. The mixture was cooled to room temperature and the volatiles were removed in vacuo. The residue was extracted with $\sim 40$ $\mathrm{mL}$ pentane and the extract was filtered through a diatomaceous earth pad to give a yellow clear solution. The volatiles were removed in vacuo to give $418.4 \mathrm{mg}$ (43\%) of yellow crystalline solid of $\mathbf{1}(\mathrm{Br})$. The residue from the pentane extraction was then extracted with $\mathrm{CH}_{2} \mathrm{Cl}_{2}$ to yield a clear yellow solution. The volatiles were removed in vacuo to give $349.7 \mathrm{mg}(36 \%)$ of light yellow crystalline solid cis- $\mathrm{Pt}\left(\mathrm{PEt}_{3}\right)_{2}(\mathrm{Br})_{2}$ 1(cisBr). Total yield was $79 \%$.

${ }^{31} \mathrm{P}\{1 \mathrm{H}\}$ NMR $\left(101 \mathrm{MHz}, \mathrm{CDCl}_{3}\right): 8.2$ (s with satellite, $\left.J_{\mathrm{PtP}}=2333 \mathrm{~Hz}\right) ;(101 \mathrm{MHz}$, $\left.\mathrm{C}_{6} \mathrm{D}_{6}\right): 8.4\left(J_{\mathrm{PtP}}=2350 \mathrm{~Hz}\right) ;\left(101 \mathrm{MHz}, \mathrm{DMSO}-\mathrm{d}_{6}\right): 10.1\left(J_{\mathrm{PtP}}=2310 \mathrm{~Hz}\right) ;(101 \mathrm{MHz}$ toluene $): 8.4\left(J_{\mathrm{PtP}}=2360 \mathrm{~Hz}\right) ;(101 \mathrm{MHz}$, ethanol $): 8.8\left(J_{\mathrm{PtP}}=2400 \mathrm{~Hz}\right) ;(101 \mathrm{MHz}$, 
diethyl ether $)$ : $9.0\left(J_{\mathrm{PtP}}=2350 \mathrm{~Hz}\right) ;(101 \mathrm{MHz}$, pentane $): 8.8\left(J_{\mathrm{PtP}}=2400 \mathrm{~Hz}\right) ;(101 \mathrm{MHz}$, MeTHF): $8.75\left(J_{\mathrm{PtP}}=2362 \mathrm{~Hz}\right)$.

${ }^{1} \mathrm{H}$ NMR (250 MHz, DMSO-d $\mathrm{d}_{6}$ ): 1.96 (asymmetric nine line pattern, $J_{\mathrm{HH}}=3.7 \mathrm{~Hz}, 12 \mathrm{H}$, $\mathrm{CH}_{2} \mathrm{CH}_{3}$ ), 1.07 (app q, $\left.J_{\mathrm{HH}}=7.9 \mathrm{~Hz}, 18 \mathrm{H}, \mathrm{CH}_{2} \mathrm{CH}_{3}\right) ;\left(\mathrm{C}_{6} \mathrm{D}_{6}\right): 1.87$ (asymmetric nine line pattern, $\left.J_{\mathrm{HH}}=3.7 \mathrm{~Hz}, 12 \mathrm{H}, \mathrm{CH}_{2} \mathrm{CH}_{3}\right), 0.98\left(\operatorname{app~q}, J_{\mathrm{HH}}=7.9 \mathrm{~Hz}, 18 \mathrm{H}, \mathrm{CH}_{2} \mathrm{CH}_{3}\right) ;(250$ $\mathrm{MHz}, \mathrm{CDCl}_{3}$ ): 2.01 (asymmetric nine line pattern, $J_{\mathrm{HH}}=3.8 \mathrm{~Hz}, 12 \mathrm{H}, \mathrm{CH}_{2} \mathrm{CH}_{3}$ ), 1.13 $\left(\operatorname{app~q}, J_{\mathrm{HH}}=7.9 \mathrm{~Hz}, 18 \mathrm{H}, \mathrm{CH}_{2} \mathrm{CH}_{3}\right)$.

trans $-\mathbf{P t}\left(\mathrm{PEt}_{3}\right)_{\mathbf{2}}(\mathrm{Br})_{\mathbf{4}} \mathbf{2}(\mathrm{Br})$. This synthesis was conducted in air. Bromine $(0.44 \mathrm{~mL}$ of a $584 \mathrm{mM} \mathrm{CH} \mathrm{Cl}_{2}$ solution) was added drop wise to a swirled yellow solution of trans$\mathrm{Pt}\left(\mathrm{PEt}_{3}\right)_{2}(\mathrm{Br})_{2} \mathbf{1}(\mathrm{Br})(140.4 \mathrm{mg}, 0.2375 \mathrm{mmol})$ in $\sim 7.5 \mathrm{~mL} \mathrm{CH} \mathrm{Cl}_{2}$. The resulting clear red solution was dried in vacuo to yield $150.7 \mathrm{~g}(85 \%)$ of trans-Pt( $\left.\mathrm{PEt}_{3}\right)_{2}(\mathrm{Br})_{4} 2(\mathrm{Br})$. The product was further washed with $\sim 0.5 \mathrm{~mL}$ cold hexane, $\sim 0.75 \mathrm{~mL}$ diethyl ether and $5 \times 1$ $\mathrm{mL}$ absolute ethanol, in vacuo to yield a powdery red solid.

${ }^{31} \mathrm{P}\left\{{ }^{1} \mathrm{H}\right\}$ NMR (101 MHz, Toluene): -9.85 (s with satellite, $\left.J_{\mathrm{PtP}}=1495 \mathrm{~Hz}\right) ;(101 \mathrm{MHz}$, DMSO-d 6$):-6.35\left(J_{\mathrm{PtP}}=1452 \mathrm{~Hz}\right) ;\left(101 \mathrm{MHz}, \mathrm{C}_{6} \mathrm{D}_{6}\right):-9.43\left(J_{\mathrm{PtP}}=1491 \mathrm{~Hz}\right) ;(101 \mathrm{MHz}$, $\left.\mathrm{CDCl}_{3}\right)$ : -9.06 $\left(J_{\mathrm{PtP}}=1478 \mathrm{~Hz}\right) ;(101 \mathrm{MHz}, \mathrm{MeTHF}):-9.95\left(J_{\mathrm{PtP}}=1496 \mathrm{~Hz}\right)$.

${ }^{1} \mathrm{H}$ NMR $\left(250 \mathrm{MHz}, \mathrm{DMSO}-\mathrm{d}_{6}\right): 2.43$ (asymmetric nine line pattern, $J_{\mathrm{HH}}=3.7 \mathrm{~Hz}, 12 \mathrm{H}$, $\left.\mathrm{CH}_{2} \mathrm{CH}_{3}\right), 1.23\left(\operatorname{app} \mathrm{q}, J_{\mathrm{HH}}=8.0 \mathrm{~Hz}, 18 \mathrm{H}, \mathrm{CH}_{2} \mathrm{CH}_{3}\right) ;\left(250 \mathrm{MHz}, \mathrm{C}_{6} \mathrm{D}_{6}\right): 2.29$ (asymmetric nine line pattern, $\left.J_{\mathrm{HH}}=3.7 \mathrm{~Hz}, 12 \mathrm{H}, \mathrm{CH}_{2} \mathrm{CH}_{3}\right), 1.02\left(\operatorname{app~q}, J_{\mathrm{HH}}=8.0 \mathrm{~Hz}\right.$, $\left.18 \mathrm{H}, \mathrm{CH}_{2} \mathrm{CH}_{3}\right) ;\left(250 \mathrm{MHz}, \mathrm{CDCl}_{3}\right): 2.48$ (asymmetric nine line pattern, $J_{\mathrm{HH}}=3.6 \mathrm{~Hz}$, $\left.12 \mathrm{H}, \mathrm{CH}_{2} \mathrm{CH}_{3}\right), 1.28\left(\operatorname{app~q}, J_{\mathrm{HH}}=8.0 \mathrm{~Hz}, 18 \mathrm{H}, \mathrm{CH}_{2} \mathrm{CH}_{3}\right)$. 
cis $-\mathbf{P t}\left(\mathbf{P E t}_{3}\right)_{2}(\mathbf{B r})_{2} 2$ (cisBr). Check synthesis of $\mathbf{1}(\mathrm{Br})$.

${ }^{31} \mathrm{P}\{1 \mathrm{H}\} \mathrm{NMR}\left(101 \mathrm{MHz}, \mathrm{CDCl}_{3}\right)$ : 9.60 (s with satellite, $\left.J_{\mathrm{PtP}}=3479 \mathrm{~Hz}\right) ;(101 \mathrm{MHz}$, DMSO-d $\left.{ }_{6}\right): 11.97\left(J_{\mathrm{PtP}}=3468 \mathrm{~Hz}\right)$.

${ }^{1} \mathrm{H}$ NMR (250 MHz, DMSO-d ${ }_{6}$ ): 2.10 (asymmetric nine line pattern, $J_{\mathrm{HH}}=7.5 \mathrm{~Hz}, 12 \mathrm{H}$, $\left.\mathrm{CH}_{2} \mathrm{CH}_{3}\right), 1.08\left(\right.$ app q, $\left.J_{\mathrm{HH}}=8.1 \mathrm{~Hz}, 18 \mathrm{H}, \mathrm{CH}_{2} \mathrm{CH}_{3}\right) ;\left(250 \mathrm{MHz}, \mathrm{CDCl}_{3}\right): 2.13$ (asymmetric nine line pattern, $\left.J_{\mathrm{HH}}=7.6 \mathrm{~Hz}, 12 \mathrm{H}, \mathrm{CH}_{2} \mathrm{CH}_{3}\right), 1.16\left(\right.$ app q, $J_{\mathrm{HH}}=8.1 \mathrm{~Hz}$, $\left.18 \mathrm{H}, \mathrm{CH}_{2} \mathrm{CH}_{3}\right)$.

cis-Pt $\left(\mathbf{P E t}_{3}\right)_{2}(\mathbf{B r})_{4} 2$ 2(cisBr). This synthesis was conducted in air and in situ. Bromine (0.02 $\mathrm{mL}$ of a $567 \mathrm{mM} \mathrm{CDCl}_{3}$ solution) was added drop wise to colorless solution of cis$\mathrm{Pt}\left(\mathrm{PEt}_{3}\right)_{2}(\mathrm{Br})_{2} \mathbf{1}(\mathrm{cisBr})(5.6 \mathrm{mg}, 9.5 \mu \mathrm{mol})$ in $\sim 1.2 \mathrm{~mL} \mathrm{CDCl}_{3}$. The resulting clear yellow solution yielded $\mathbf{2}(\mathrm{cisBr})$.

${ }^{31} \mathrm{P}\left\{{ }^{1} \mathrm{H}\right\}$ NMR $\left(101 \mathrm{MHz}, \mathrm{CDCl}_{3}\right): 3.65\left(J_{\mathrm{PtP}}=2029 \mathrm{~Hz}\right)$.

${ }^{1} \mathrm{H}$ NMR $\left(250 \mathrm{MHz}, \mathrm{CDCl}_{3}\right.$ ): 2.48 (asymmetric nine line pattern, $J_{\mathrm{HH}}=3.6 \mathrm{~Hz}, 12 \mathrm{H}$, $\mathrm{CH}_{2} \mathrm{CH}_{3}$ ), 1.28 (app q, $J_{\mathrm{HH}}=8.0 \mathrm{~Hz}, 18 \mathrm{H}, \mathrm{CH}_{2} \mathrm{CH}_{3}$ ).

$\operatorname{Pt}(\mathbf{C O D})(\mathbf{B r})_{2} \mathbf{1}(\mathbf{C O D})$. This compound has been previously reported via a different synthesis. $^{72,73}$ Outside the drybox to $\operatorname{Pt}(\mathrm{COD})(\mathrm{Cl})_{2}(105 \mathrm{mg}, 0.279$ mmoles $)$ in acetone ( $\sim 7 \mathrm{~mL})$ excess $\mathrm{NaBr}(\sim 235 \mathrm{mg}, 2.28$ mmoles) was added and stirred for 5 hours at 29 ${ }^{0} \mathrm{C}$. The reaction mixture was washed with water $(3 \mathrm{X} \sim 5 \mathrm{~mL})$ and then dried in vacuo to yield $24.2 \mathrm{mg}$ (19\%) of pale yellow $\mathbf{1}(\mathrm{COD})$.

${ }^{195} \mathrm{Pt}$ NMR (64 MHz, $\left.\mathrm{CDCl}_{3}\right):-3649$ (s) 
${ }^{1} \mathrm{H}$ NMR $\left(250 \mathrm{MHz}, \mathrm{CDCl}_{3}\right.$ ): 5.66 (s with satellite, 4H, $\mathrm{C}$ ), 2.60 (b, 4H, $\underline{\mathrm{H}}_{2}$ ), 2.23-2.04 (app d, 4H, $\underline{\mathrm{CH}}_{2}$ )

$\operatorname{Pt}(\mathbf{d e p e})(\mathbf{B r})_{2}$ 1(depe). This compound has been previously reported via a different synthesis. ${ }^{74,75}$ Outside the drybox to a pale yellow cloudy solution of $\mathrm{Pt}(\mathrm{COD})(\mathrm{Br})_{2}(7.5$ $\mathrm{mg}, 16 \mu$ moles $)$ in toluene $(\sim 0.7 \mathrm{~mL})$, depe $(0.64 \mathrm{~mL}$ of a $25 \mathrm{mM}$ toluene solution) was added under constant stirring. The resulting cloudy solution was stirred overnight and then dried in vacuo. The residue was extracted using $\mathrm{CH}_{2} \mathrm{Cl}_{2}(\sim 5 \mathrm{~mL})$ and further dried in vacuo to yield a pale yellow residue. This was washed with $3 \mathrm{X} \sim 1 \mathrm{~mL}$ hexane and the volatiles were then removed in vacuo to yield $7.3 \mathrm{mg}$ ( $80 \%$ ) of pale yellow $\mathbf{1}$ (depe).

${ }^{31} \mathrm{P}\{1 \mathrm{H}\}$ NMR $\left(101 \mathrm{MHz}, \mathrm{CDCl}_{3}\right): 60.57$ (s with satellite, $\left.J_{\mathrm{PtP}}=3482 \mathrm{~Hz}\right) ;(101 \mathrm{MHz}$, $\mathrm{CD}_{2} \mathrm{Cl}_{2}$ ): 60.80 (s with satellite, $J_{\mathrm{PtP}}=3486 \mathrm{~Hz}$ ); $\left(101 \mathrm{MHz}, \mathrm{DMSO}-\mathrm{d}_{6}\right.$ ): 63.53 (s with satellite, $\left.J_{\mathrm{PtP}}=3484 \mathrm{~Hz}\right)$.

${ }^{1} \mathrm{H}$ NMR (250 MHz, $\mathrm{CD}_{2} \mathrm{Cl}_{2}$ ): 2.53-1.65 (overlaping ms \& app d, 8H \& 4H, $\mathrm{PC}_{2} \mathrm{CH}_{3} \&$ $\left.\mathrm{PC}_{2}{ }_{\mathrm{C}} \underline{\mathrm{H}}_{2} \mathrm{P}\right), 1.34-1.09\left(\mathrm{~m}, 12 \mathrm{H}, \mathrm{PCH}_{2} \underline{\mathrm{C}}_{3}\right)$

$\operatorname{Pt}($ depe $)(B r)_{4}$ 2(depe). Inside the drybox to a white suspension of $\mathrm{Pt}(\mathrm{COD})(\mathrm{Cl})_{2}(35.3$ mg, $94.3 \mu$ moles $)$ in $1 \mathrm{~mL} \mathrm{CH}_{2} \mathrm{Cl}_{2}$, depe $(19.0 \mathrm{mg}, 92.1 \mu$ moles $)$ in $1 \mathrm{~mL} \mathrm{CH}_{2} \mathrm{Cl}_{2}$ was added under constant stirring. The depe vial was further washed with $3 \mathrm{~mL} \mathrm{CH}_{2} \mathrm{Cl}_{2}$. The washings were also added to the reaction mixture and the resulting pale yellow clear solution was taken out of the drybox. Then $\operatorname{KBr}(\sim 300 \mathrm{mg})$ and absolute ethanol ( 4 mL) was added to the solution. The resulting reaction mixture slurry was stirred for 30 minutes and dried in vacuo. The residue was extracted using $\mathrm{CH}_{2} \mathrm{Cl}_{2}(\sim 1 \mathrm{~mL})$ and then 67 
filtered through a diatomaceous earth pad to give a pale yellow clear solution of $\mathbf{1}$ (depe). To this bromine $\left(0.10 \mathrm{~mL}\right.$ of a $0.93 \mathrm{M} \mathrm{CH}_{2} \mathrm{Cl}_{2}$ solution) was added drop-wise under constant stirring to yield an orange precipitate. The solution was separated and the orange residue was dried in vacuo to yield $34 \mathrm{mg}$ (50\%) 2 (depe).

${ }^{31} \mathrm{P}\left\{{ }^{1} \mathrm{H}\right\} \mathrm{NMR}\left(101 \mathrm{MHz}, \mathrm{CH}_{2} \mathrm{Cl}_{2}\right): 50.94$ (s with satellite, $\left.J_{\mathrm{PtP}}=2050 \mathrm{~Hz}\right) ;(101 \mathrm{MHz}$, DMSO-d ${ }_{6}$ ): 57.09 (s with satellite, $J_{\mathrm{PtP}}=2032 \mathrm{~Hz}$ ).

${ }^{1} \mathrm{H}$ NMR (250 MHz, DMSO-d $\left.{ }_{6}\right): 2.76-2.53\left(\mathrm{~m}, 8 \mathrm{H}, \mathrm{PC}_{2} \mathrm{CH}_{3}\right), 2.40\left(\operatorname{app~d}, J_{\mathrm{HH}}=17.51\right.$ $\left.\mathrm{Hz}, 4 \mathrm{H}, \mathrm{PC}_{2} \underline{\mathrm{CH}}_{2} \mathrm{P}\right), 1.36-1.20\left(\mathrm{~m}, 12 \mathrm{H}, \mathrm{PCH}_{2} \underline{\mathrm{CH}}_{3}\right)$

trans-Pt(PEt $)_{2}(\mathbf{B r})\left(2\right.$-(trifluoromethy)phenyl) $1\left(\mathrm{CF}_{3} \mathbf{P h}\right)$. A clear orange solution of $\mathrm{Pt}\left(\mathrm{PEt}_{3}\right)_{4}(128.6 \mathrm{mg}, 0.1926 \mathrm{mmol})$ in $\mathrm{THF}(\sim 10 \mathrm{~mL})$ was added to a colorless THF $(\sim 4$ $\mathrm{mL}$ ) solution of 2-bromo(trifluoromethy)phenyl (30 $\mu \mathrm{L}, 50 \mathrm{mg}, 0.22 \mathrm{mmol})$. The resulting clear orange solution was stirred for $9.5 \mathrm{~h}$ at $127{ }^{0} \mathrm{C}$ in a sealed tube to yield a pale yellow solution. The mixture was cooled to ambient temperature and the volatiles removed in vacuo. The residue was washed with $2 \mathrm{x} \sim 0.5 \mathrm{~mL}$ cold hexane and then extracted with $5 \mathrm{x} \sim 2 \mathrm{~mL} \mathrm{CH}_{2} \mathrm{Cl}_{2}$. The extract was filtered through a diatomaceous earth pad. The volatiles were then removed in vacuo to yield $96.8 \mathrm{mg}(77 \%)$ of pale yellow solid $\mathbf{1}\left(\mathrm{CF}_{3} \mathrm{Ph}\right)$.

${ }^{31} \mathrm{P}\left\{{ }^{1} \mathrm{H}\right\}$ NMR $\left(101 \mathrm{MHz}, \mathrm{CDCl}_{3}\right): 9.1$ (s with satellites, $J_{\mathrm{PtP}}=2698 \mathrm{~Hz}$ ). A similar shift and coupling constant was observed in $\mathrm{C}_{6} \mathrm{D}_{6}$ and THF.

${ }^{19} \mathrm{~F}\left\{{ }^{1} \mathrm{H}\right\}$ NMR $\left(235 \mathrm{MHz}, \mathrm{CDCl}_{3}\right):-59.74$ (s with satellites, $J_{\mathrm{PF}}=17.42 \mathrm{~Hz}$ ).

${ }^{1} \mathrm{H}$ NMR (250 MHz, $\mathrm{CDCl}_{3}$ ): 7.71 (d with satellites, $J_{\mathrm{PtH}}=75.79 \mathrm{~Hz}, J_{\mathrm{HH}}=7.50 \mathrm{~Hz}, 1 \mathrm{H}$, H6), 7.37 (dd with satellites, $J_{\mathrm{FH}}=25.01 \mathrm{~Hz}, J_{\mathrm{HH}}=7.63 \mathrm{~Hz}, J_{\mathrm{HH}}=1.63 \mathrm{~Hz}, \mathrm{H} 3$ ), $7.01-$ 68 
6.88 (multiplet, 2H, H4 \& H5), 1.79-1.50 (symmetric 20 line multiplet, $12 \mathrm{H}, \mathrm{CH}_{2} \mathrm{CH}_{3}$ ), 1.02 (app quintet, $J=7.82 \mathrm{~Hz}, 18 \mathrm{H}, \mathrm{CH}_{2} \mathrm{CH}_{3}$ ).

${ }^{1} \mathrm{H}$ NMR (250 MHz, $\mathrm{C}_{6} \mathrm{D}_{6}$ ): 7.83 (d with satellites, $\left.J_{\mathrm{PtH}}=73.79 \mathrm{~Hz}, 1 \mathrm{H}, \mathrm{H} 6\right), 7.53$ (d, with satellites, $J_{\mathrm{FH}}=25.76 \mathrm{~Hz}, J_{\mathrm{HH}}=8.00 \mathrm{~Hz}, 1 \mathrm{H}, \mathrm{H} 3$ ), 6.85 (overlapping t, $2 \mathrm{H}, \mathrm{H} 4 \&$ H5), 1.77-1.44 (symmetric 24 line multiplet, $12 \mathrm{H}, \mathrm{CH}_{2} \mathrm{CH}_{3}$ ), 0.88 (app quintet, $J=7.82$ $\left.\mathrm{Hz}, 18 \mathrm{H}, \mathrm{CH}_{2} \mathrm{CH}_{3}\right)$.

trans $-\mathbf{P t}\left(\mathrm{PEt}_{3}\right)_{2}(\mathbf{B r})_{3}\left(2\right.$-(trifluoromethy)phenyl) $\mathbf{2}\left(\mathrm{CF}_{3} \mathbf{P h}\right)$. This synthesis was carried out in air. To $81.0 \mathrm{mg}$ of $\mathbf{1}\left(\mathrm{CF}_{3} \mathrm{Ph}\right)(0.123 \mathrm{mmol})$ in $\mathrm{CH}_{2} \mathrm{Cl}_{2}(\sim 8 \mathrm{~mL}), 0.2 \mathrm{~mL}$ of $0.75 \mathrm{M}$ bromine $(0.15 \mathrm{mmol})$ in $\mathrm{CH}_{2} \mathrm{Cl}_{2}$ was added drop-wise. The resulting solution was stirred for $5 \mathrm{~min}$ and the volatiles were then removed in vacuo to give $106.9 \mathrm{mg}$ (quantitative) of solid yellow 2(CF $\left(\mathrm{CF}_{3} \mathrm{Ph}\right) .{ }^{31} \mathrm{P}\left\{{ }^{1} \mathrm{H}\right\}$ NMR (101 $\mathrm{MHz}, \mathrm{CH}_{2} \mathrm{Cl}_{2}$ or $\mathrm{CDCl}_{3}$ ): -8.5 (s with satellites, $J_{\mathrm{PtP}}=1592 \mathrm{~Hz}$ ).

${ }^{19} \mathrm{~F}\left\{{ }^{1} \mathrm{H}\right\} \mathrm{NMR}\left(235 \mathrm{MHz}, \mathrm{CDCl}_{3}\right):-50.06(\mathrm{~s})$.

${ }^{1} \mathrm{H}$ NMR $\left(250 \mathrm{MHz}, \mathrm{CDCl}_{3}\right): 8.72$ (d with satellites, $J_{\mathrm{PtH}}=49.23 \mathrm{~Hz}, J_{\mathrm{HH}}=8.25 \mathrm{~Hz}, 1 \mathrm{H}$, H6), 7.49 (dd with satellites, $\left.J_{\mathrm{FH}}=20.76 \mathrm{~Hz}, J_{\mathrm{HH}}=7.75 \mathrm{~Hz}, J_{\mathrm{HH}}=1.75 \mathrm{~Hz}, \mathrm{H} 3\right), 7.18(\mathrm{t}$, $\left.J_{\mathrm{HH}}=7.38 \mathrm{~Hz}, 1 \mathrm{H}\right), 7.02\left(\mathrm{dt}, J_{\mathrm{HH}}=6.88 \mathrm{~Hz}, 1 \mathrm{H}\right) 2.37-2.25$ (symmetric nine-line pattern, $J=3.63 \mathrm{~Hz}, 12 \mathrm{H}, \mathrm{CH}_{2} \mathrm{CH}_{3}$ ), 1.02 (app quintet, $J=7.88 \mathrm{~Hz}, 18 \mathrm{H}, \mathrm{CH}_{2} \mathrm{CH}_{3}$ ).

trans-Pt $\left(\mathrm{PEt}_{3}\right)_{2}(\mathrm{Br})$ (2,6-dimethoxyphenyl) 1( $\left.\mathrm{MeO}_{2} \mathrm{Ph}\right)$. A clear orange solution of $\mathrm{Pt}\left(\mathrm{PEt}_{3}\right)_{4}(205.0 \mathrm{mg}, 0.3070 \mathrm{mmol})$ in $\mathrm{C}_{6} \mathrm{D}_{6}(\sim 4 \mathrm{~mL})$ was added to a pale yellowish brown $\mathrm{C}_{6} \mathrm{D}_{6}(\sim 3 \mathrm{~mL})$ solution of 2-bromo-1,3-dimethoxybenzene $(69.2 \mathrm{mg}, 0.319 \mathrm{mmol})$ drop-wise with constant stirring. The resulting clear orange solution was stirred for an 69 
hour at room temperature and further heated for $18 \mathrm{~h}$ at $117{ }^{\circ} \mathrm{C}$ in a sealed tube to yield an orange yellow solution. The volatiles were then removed in vacuo to give a pale brownish yellow solid. To this $\sim 5 \mathrm{~mL}$ of hexane was added and heated at $84{ }^{0} \mathrm{C}$ for $2 \mathrm{~min}$. This yielded a yellow clear solution which was left for recrystallization. The colorless crystals were then washed with $3 \times \sim 0.3 \mathrm{~mL}$ hexane. The volatiles were then removed in vacuo to yield a pale yellow crystalline solid. This was further washed with $2 \mathrm{x} \sim 2 \mathrm{~mL}$ distilled water and heated at $84{ }^{\circ} \mathrm{C}$ for $10 \mathrm{~min}$. This yielded a pale orange sticky solid. This was dissolved in $\mathrm{CDCl}_{3}$ for ${ }^{1} \mathrm{H}$ and ${ }^{31} \mathrm{P}$ NMR spectroscopy. Then the volatiles were removed in vacuo to yield $154.4 \mathrm{mg}(78 \%)$ of crude $\mathbf{1}\left(\mathrm{MeO}_{2} \mathrm{Ph}\right)$. To this $0.3287 \mathrm{KBr}$ and $\sim 2 \mathrm{~mL}$ absolute ethanol was added and the yellow solution was heated for 1.5 hours at 84 ${ }^{0} \mathrm{C}$. All the ethanol had evaporated and further $\sim 2 \mathrm{~mL}$ of ethanol was added and the solution was left stirring overnight. Then the volatiles were removed in vacuo and 1( $\left(\mathrm{MeO}_{2} \mathrm{Ph}\right)$ was extracted using $\mathrm{CH}_{2} \mathrm{Cl}_{2}$. The volatiles were further removed in vacuo to yield $132.4 \mathrm{mg}(67 \%)$ of a pale yellow waxy solid $\mathbf{1}\left(\mathrm{MeO}_{2} \mathrm{Ph}\right)$. Anal. Calc. (found) for C20H39O2PtP2Br: C, 37.04 (37.23); H, 6.06 (6.50); N, 0.00 (0.07).

${ }^{31} \mathrm{P}\left\{{ }^{1} \mathrm{H}\right\}$ NMR $\left(101 \mathrm{MHz}, \mathrm{C}_{6} \mathrm{D}_{6}\right.$ or $\left.\mathrm{CDCl}_{3}\right): 12.7$ (s with satellites, $J_{\mathrm{PtP}}=2745 \mathrm{~Hz}$ ). ${ }^{1} \mathrm{H}$ NMR $\left(250 \mathrm{MHz}, \mathrm{CDCl}_{3}\right): 6.95\left(\mathrm{t}, J_{\mathrm{HH}}=8.0 \mathrm{~Hz}, 1 \mathrm{H}, \mathrm{H} 4\right), 6.25\left(\mathrm{~d}\right.$ with satellites $J_{\mathrm{PtH}}=$ $\left.23.87 \mathrm{~Hz}, J_{\mathrm{HH}}=8.0 \mathrm{~Hz}, 2 \mathrm{H}, \mathrm{H} 5 \& \mathrm{H} 3\right), 3.66\left(\mathrm{~s}, 6 \mathrm{H}, \mathrm{OCH}_{3}\right)$ 1.67-1.53 (symmetric 10 line pattern, $J=3.70 \mathrm{~Hz}, 12 \mathrm{H}, \mathrm{CH}_{2} \mathrm{CH}_{3}$ ), 1.00 (app quintet, $J=7.84 \mathrm{~Hz}, 18 \mathrm{H}, \mathrm{CH}_{2} \mathrm{CH}_{3}$ ).

trans-Pt $\left(\mathrm{PEt}_{3}\right)_{2}(\mathrm{Br})_{3}$ (3,5-dibromo-2,6-dimethoxyphenyl) $\quad \mathbf{2}_{\left(\mathrm{BrMeO}_{2} \mathbf{P h}\right) .} \quad$ This synthesis was carried out in air. Bromine $(22 \mathrm{mg}, 0.14 \mathrm{mmol})$ in $\mathrm{CDCl}_{3}(0.18 \mathrm{~mL}$ of a 0.77 M solution) was added drop-wise with constant stirring to a pale yellow solution of 
$\mathbf{1}\left(\mathrm{MeO}_{2} \mathrm{Ph}\right)(24.0 \mathrm{mg}, 37.0 \mu \mathrm{mol})$ in $\mathrm{CDCl}_{3}(\sim 0.5 \mathrm{~mL})$. The resulting orange red solution was further stirred for $1.5 \mathrm{~h}$. The volatiles were then removed in vacuo to give $36.7 \mathrm{mg}$ (quantitative) orange crystalline product.

${ }^{31} \mathrm{P}\left\{{ }^{1} \mathrm{H}\right\}$ NMR (101 MHz, $\left.\mathrm{CDCl}_{3}\right):-7.24$ (s with satellites, $\left.J_{\mathrm{PtP}}=1570 \mathrm{~Hz}\right)$.

${ }^{1} \mathrm{H}$ NMR (250 MHz, $\left.\mathrm{CDCl}_{3}\right): 7.61$ (s, 1H, H4), 4.05 (s, 6H, $\mathrm{OCH}_{3}$ ), 2.45 (broad multiplet, $12 \mathrm{H}, \mathrm{CH}_{2} \mathrm{CH}_{3}$ ), 1.14 (broad app triplet, $18 \mathrm{H}, \mathrm{CH}_{2} \mathrm{CH}_{3}$ ).

trans-Pt $\left(\mathbf{P E t}_{3}\right)_{2}(\mathbf{B r})(2$-aminophenyl) 1(NPh). A sealable tube was charged with a clear purple THF ( 3 mL) solution of 2-bromophenylamine $(51.4 \mathrm{mg}, 0.299 \mathrm{mmol})$. A clear orange solution of $\mathrm{Pt}\left(\mathrm{PEt}_{3}\right)_{4}(195.4 \mathrm{mg}, 0.2926 \mathrm{mmol})$ in $\mathrm{THF}(\sim 4 \mathrm{~mL})$ was added dropwise with stirring. $\sim 5 \mathrm{~mL}$ more THF was added to the resulting clear yellowish orange solution. The tube was sealed and the mixture was stirred for $2.5 \mathrm{~h}$ at room temperature and then heated for $17 \mathrm{~h}$ at $117{ }^{\circ} \mathrm{C}$ to yield a yellow clear solution. After cooling to ambient temperature the volatiles were removed in vacuo to give a yellowish green residue. This was then extracted with $5 \mathrm{x} \sim 2 \mathrm{~mL} \mathrm{CH}_{2} \mathrm{Cl}_{2}$. The combined extracts were filtered through diatomaceous earth and dried in vacuo to yield a brown residue. To this $\sim 5 \mathrm{~mL}$ of hexane was added and the mixture heated for $2 \mathrm{~min}$ and cooled. This yielded a clear yellow solution with a brown residue at the bottom. The yellow solution was decanted into a clean vial and left to evaporate. Pale yellow crystals and $\sim 0.3 \mathrm{~mL}$ of pale brown mother liquor were obtained. The mother liquor was removed with a pipette and the crystals were washed with $2 \times \sim 0.3 \mathrm{~mL}$ hexane and dried in vacuo. ${ }^{31} \mathrm{P}$ NMR spectroscopy of the crystals indicated the presence of $\mathrm{PEt}_{3} \mathrm{O}$ and possibly the chloro analogue of $\mathbf{1}(\mathrm{NPh})$. Hence the NMR sample was combined with the crystals and the 
solvent removed in vacuo. The solid was then washed with $2 \mathrm{x} \sim 2 \mathrm{~mL}$ distilled water and dried for $\sim 10 \mathrm{~min}$ at $84{ }^{0} \mathrm{C}$. After this, $0.30 \mathrm{~g}$ of $\mathrm{KBr}$ and $\sim 2 \mathrm{~mL}$ of absolute ethanol was added to the solid and the mixture heated in an open vial for an hour at $84{ }^{\circ} \mathrm{C}$. The solvent volume had reduced to $\sim \mathrm{ml}$. Another $1 \mathrm{~mL}$ of ethanol was added and the yellow solution was left stirring overnight at room temperature. ${ }^{31} \mathrm{P}$ NMR spectroscopy showed complete conversion of the chloro compound to $\mathbf{1}(\mathrm{NPh})$. Ethanol was removed in vacuo and $\mathbf{1}(\mathrm{NPh})$ was extracted from the residue using $5 \mathrm{x} \sim 2 \mathrm{~mL}$ of $\mathrm{CH}_{2} \mathrm{Cl}_{2}$. The combined extracts were filtered through diatomaceous earth and dried in vacuo to yield $91.4 \mathrm{mg}$ (52 $\%)$ of a pale brown waxy solid.

${ }^{31} \mathrm{P}\left\{{ }^{1} \mathrm{H}\right\}$ NMR $\left(101 \mathrm{MHz}, \mathrm{CDCl}_{3}\right): 14.3$ (s with satellites, $J_{\mathrm{PtP}}=2674 \mathrm{~Hz}$ ).

${ }^{31} \mathrm{P}\left\{{ }^{1} \mathrm{H}\right\}$ NMR $(101 \mathrm{MHz}, \mathrm{THF}): 14.3$ (s with satellites, $J_{\mathrm{PtP}}=2702 \mathrm{~Hz}$ ).

${ }^{1} \mathrm{H}$ NMR $\left(250 \mathrm{MHz}, \mathrm{CDCl}_{3}\right): 7.15$ (d with satellites, $J_{\mathrm{PtH}}=73.2 \mathrm{~Hz}, J_{\mathrm{HH}}=7.4 \mathrm{~Hz}, 1 \mathrm{H}$, H6), $6.76\left(\mathrm{t}, J_{\mathrm{HH}}=8.1 \mathrm{~Hz}, 1 \mathrm{H}, \mathrm{H} 5\right), 6.46-6.33$ (multiplet, 2H, H3 \& H4), $4.01(\mathrm{~s}, 2 \mathrm{H}$, $\mathrm{NH}_{2}$ ) 1.82-1.62 (symmetric 12 line patern, $12 \mathrm{H}, \mathrm{CH}_{2} \mathrm{CH}_{3}$ ), 1.04 (app quintet, $J=7.2 \mathrm{~Hz}$, $\left.18 \mathrm{H}, \mathrm{CH}_{2} \mathrm{CH}_{3}\right) .{ }^{1} \mathrm{H} \mathrm{NMR}\left(500 \mathrm{MHz}, \mathrm{CDCl}_{3}\right): 7.15$ (d with satellites, $J_{\mathrm{PtH}}=71.0 \mathrm{~Hz}, J_{\mathrm{HH}}$ $=7.5 \mathrm{~Hz}, 1 \mathrm{H}, \mathrm{H} 6), 6.76\left(\mathrm{t}, J_{\mathrm{HH}}=7.2 \mathrm{~Hz}, 1 \mathrm{H}, \mathrm{H} 5\right), 6.44-6.39$ (multiplet, 2H, H3 \& H4), $4.01\left(\mathrm{~s}, 2 \mathrm{H}, \mathrm{NH}_{2}\right)$ 1.80-1.63 (symmetric 9 line pattern, $J=3.7 \mathrm{~Hz}, 12 \mathrm{H}, \mathrm{CH}_{2} \mathrm{CH}_{3}$ ), 1.05 (app quintet, $J=7.9 \mathrm{~Hz}, 18 \mathrm{H}, \mathrm{CH}_{2} \mathrm{CH}_{3}$ ).

trans-Pt $\left(\mathrm{PEt}_{3}\right)_{2}(\mathrm{Br})_{3}(\mathbf{3 , 5}$-dibromo-2-aminophenyl) 2(BrNPh). This synthesis was carried out in air. To $26.8 \mathrm{mg}(44.4 \mu \mathrm{mol})$ of a clear brownish yellow solution of $\mathbf{1}(\mathrm{NPh})$ in $\mathrm{CDCl}_{3}(\sim 7 \mathrm{~mL})$ was added $1.00 \mathrm{~mL}$ of $0.19 \mathrm{M}$ bromine $(190 \mu \mathrm{mol})$ with stirring. ${ }^{31} \mathrm{P}$ NMR spectroscopy of the mixture indicated complete bromination of Pt but incomplete 
ring bromination. Another $0.18 \mathrm{~mL}$ of $0.78 \mathrm{M}$ bromine $(140 \mu \mathrm{mol})$ in $\mathrm{CDCl}_{3}$ was added drop-wise with stirring to complete the reaction. The volatiles were then removed in vacuo to give a maroon oily residue. The residue was dissolved in $\sim 3 \mathrm{~mL}$ of $\mathrm{CDCl}_{3}$ and $0.45 \mathrm{~g}$ of $\mathrm{NaHCO}_{3}$ was added. The orange solution was stirred for $30 \mathrm{~min}$ and filtered through diatomaceous earth. It was further dried in vacuo to yield $40.8 \mathrm{mg}$ (quantitative) of a reddish orange solid $2(\mathrm{BrNPh})$.

${ }^{31} \mathrm{P}\left\{{ }^{1} \mathrm{H}\right\}$ NMR $\left(101 \mathrm{MHz}, \mathrm{CDCl}_{3}\right)$ : -7.13 (s with satellites, $J_{\mathrm{PtP}}=1574 \mathrm{~Hz}$ ).

${ }^{1} \mathrm{H}$ NMR (250 MHz, $\mathrm{CDCl}_{3}$ ): 7.89 (dd with satellites, $J_{\mathrm{PtH}}=51.28 \mathrm{~Hz}, J_{\mathrm{HH}}=2.00 \mathrm{~Hz}, 1 \mathrm{H}$, H6), $7.35\left(\mathrm{dd}, J_{\mathrm{HH}}=2.00 \mathrm{~Hz}, 1 \mathrm{H}, \mathrm{H} 4\right), 5.51\left(\mathrm{~s}, 2 \mathrm{H}, \mathrm{NH}_{2}\right)$ 2.46-2.32 (symmetric 10 line pattern, $J=3.78 \mathrm{~Hz}, 12 \mathrm{H}, \mathrm{CH}_{2} \mathrm{CH}_{3}$ ), 1.13 (app quintet, $J=7.94 \mathrm{~Hz}, 18 \mathrm{H}, \mathrm{CH}_{2} \mathrm{CH}_{3}$ ).

trans-Pt $\left(\mathbf{P E t}_{3}\right)_{2}(\mathrm{Br})$ (2-isopropoxylphenyl) 1(iPrOPh). A clear orange solution of $\mathrm{Pt}\left(\mathrm{PEt}_{3}\right)_{4}(135.6 \mathrm{mg}, 0.2031 \mathrm{mmol})$ in $\mathrm{THF}(\sim 3 \mathrm{~mL})$ was added to a clear solution of 2isopropoxyphenyl ether $(0.04 \mathrm{~mL}, 50 \mathrm{mg}, 0.25 \mathrm{mmol})$ dissolved in THF ( 2 mL). The resulting clear orange solution was stirred overnight at $126{ }^{\circ} \mathrm{C}$ during which time it turned a pale yellow. The mixture was cooled to room temperature and the volatiles were removed in vacuo to give a pale yellow solid. The solid was washed with $2 \mathrm{X} \sim 0.5 \mathrm{~mL}$ cold hexane and dried in vacuo to yield $90 \mathrm{mg}$ pale yellow 1(iPrOPh) (69\%).

${ }^{31} \mathrm{P}\left\{{ }^{1} \mathrm{H}\right\}$ NMR $\left(101 \mathrm{MHz}, \mathrm{CDCl}_{3}\right): 12.59$ (s with satellites, $\left.J_{\mathrm{PtP}}=2766 \mathrm{~Hz}\right) ;(101 \mathrm{MHz}$, THF): $12.71\left(J_{\mathrm{PtP}}=2777 \mathrm{~Hz}\right)$.

trans-Pt $\left(\mathrm{PEt}_{3}\right)_{2}(\mathrm{Br})_{3}($ 5-bromo-2-isopropoxyphenyl) 2(BriPrOPh). This synthesis was carried out in air and the complex was not isolated. To $8.7 \mathrm{mg}$ of $\mathbf{1}(\mathrm{iPrOPh})(13 \mu \mathrm{mol})$ in 
$\mathrm{CDCl}_{3}(\sim 0.6 \mathrm{~mL}), 0.21 \mathrm{~mL}$ of $0.19 \mathrm{M}$ bromine $(0.01 \mathrm{~mL}, 31 \mathrm{mg}, 19 \mathrm{mmol})$ in $\mathrm{CDCl}_{3}$ was added drop-wise resulting in a red clear solution of $\mathbf{2}(\mathrm{BriPrOPh})$.

${ }^{31} \mathrm{P}$ NMR $\left(101 \mathrm{MHz}, \mathrm{CDCl}_{3}\right):-8.30$ (s with satellites, $J_{\mathrm{PtP}}=1607 \mathrm{~Hz}$ ).

trans-Pt $\left(\mathbf{P E t}_{3}\right)_{2}(\mathbf{B r})$ (4-bromo-1-naphthyl) 1(BrNap). This compound was previously synthesized from $\mathbf{1}(\mathrm{BrNap}){ }^{41}$ A clear orange solution of $\mathrm{Pt}\left(\mathrm{PEt}_{3}\right)_{4}(623.7 \mathrm{mg}, 0.9341$ mmol) in THF $(\sim 7 \mathrm{~mL})$ was added to a clear pale yellow solution of 1,4dibromonaphthalene (270.6 $\mathrm{mg}, 0.9463 \mathrm{mmol})$ dissolved in THF $(\sim 6 \mathrm{~mL})$. The resulting clear orange solution was stirred for $8 \mathrm{~h}$ at $120{ }^{\circ} \mathrm{C}$ during which time it turned a pale yellow. The mixture was cooled to room temperature and the volatiles were removed in vacuo to give a pale yellow oily residue. The residue was extracted with $5 \times 3 \mathrm{~mL}$ of $\mathrm{CH}_{2} \mathrm{Cl}_{2}$ and the combined extracts were filtered through diatomaceous earth. The filtrate was dried in vacuo to yield a pale yellow waxy solid. The solid was dissolved in a minimum volume of $\mathrm{CH}_{2} \mathrm{Cl}_{2}$ and the solution was layered with $\mathrm{CH}_{3} \mathrm{OH}$. The resulting pale yellow crystals were isolated, washed with methanol $(2 \times 1.0 \mathrm{~mL})$ and dried in vacuo to give $507.0 \mathrm{mg}(76 \%)$ of white solid.

${ }^{31} \mathrm{P}\left\{{ }^{1} \mathrm{H}\right\}$ NMR $\left(101 \mathrm{MHz}, \mathrm{CDCl}_{3}\right): 11.7$ (s with satellites, $\left.J_{\mathrm{PtP}}=2681 \mathrm{~Hz}\right) ;(101 \mathrm{MHz}$, MeTHF): $12.35\left(J_{\mathrm{PtP}}=2692 \mathrm{~Hz}\right)$.

${ }^{1} \mathrm{H} \mathrm{NMR}\left(500 \mathrm{MHz}, \mathrm{CDCl}_{3}\right): 8.71$ (dd with satellites, $J_{\mathrm{HH}}=7.3 \mathrm{~Hz}, J_{\mathrm{HH}}=2.3 \mathrm{~Hz}, 1 \mathrm{H}$, $\mathrm{H} 8), 8.10\left(\mathrm{~d}, J_{\mathrm{HH}}=7.5 \mathrm{~Hz}, J_{\mathrm{HH}}=2.3 \mathrm{~Hz}, 1 \mathrm{H}, \mathrm{H} 5\right), 7.47-7.31(\mathrm{~m}, 4 \mathrm{H}, \mathrm{H} 2, \mathrm{H} 3, \mathrm{H} 6$ and $\mathrm{H} 7$ ), 1.71-1.37 (symmetric 25 line multiplet, $12 \mathrm{H}, \mathrm{CH}_{2} \mathrm{CH}_{3}$ ), 0.97 (app quintet, $J=7.9$ $\left.\mathrm{Hz}, 18 \mathrm{H}, \mathrm{CH}_{2} \mathrm{CH}_{3}\right)$. 
trans-Pt(PEt $)_{2}\left(\mathrm{Br}_{3}\right.$ (4-bromo-1-naphthyl) 2(BrNap). This synthesis was carried out in air. To a $134.7 \mathrm{mg}$ of $\mathbf{1}(\mathrm{BrNap})(0.1878 \mathrm{mmol})$ in $\mathrm{CDCl}_{3}(1 \mathrm{~mL}), 0.72 \mathrm{~mL}$ of $267.4 \mathrm{mM}$ bromine $(9.9 \mu \mathrm{L}, 30.8 \mathrm{mg}, 0.1925 \mathrm{mmol})$ in $\mathrm{CH}_{2} \mathrm{Cl}_{2}$ was added drop-wise resulting in an orange red clear solution. The volatiles were removed in vacuo to give $157.2 \mathrm{mg}(95 \%)$ of orange solid 2(BrNap).

${ }^{31} \mathrm{P}$ NMR $\left(101 \mathrm{MHz}, \mathrm{CDCl}_{3}\right):-8.41$ (s with satellites, $\left.J_{\mathrm{PtP}}=1610 \mathrm{~Hz}\right) ;(101 \mathrm{MHz}$, MeTHF):

$-9.66\left(J_{\mathrm{PtP}}=1622 \mathrm{~Hz}\right)$.

${ }^{1} \mathrm{H}$ NMR $\left(250 \mathrm{MHz}, \mathrm{CDCl}_{3}\right): 8.90\left(\mathrm{~d}, J_{\mathrm{HH}}=9.7 \mathrm{~Hz}, 1 \mathrm{H}, \mathrm{H} 8\right), 8.17$ (dd with satellites, $J_{\mathrm{PtH}}$ $=48.2 \mathrm{~Hz}, J_{\mathrm{HH}}=8.4 \mathrm{~Hz}, 2 \mathrm{H}, \mathrm{H} 2, \mathrm{H} 3$ ), 7.52-7.36 (overlaping $\mathrm{m} \& \mathrm{~d}, 3 \mathrm{H}, \mathrm{H} 7, \mathrm{H} 6$ and H5), 2.32 (asymmetric 18 line splitting pattern, $\left.J_{\mathrm{HH}}=3.7 \mathrm{~Hz}, 12 \mathrm{H}, \mathrm{PC}_{2} \mathrm{CH}_{3}\right), 1.01$ (app $\left.\mathrm{q}, J_{\mathrm{HH}}=7.9 \mathrm{~Hz}, 18 \mathrm{H}, \mathrm{PCH}_{2} \mathrm{CH}_{3}\right)$.

Di-trans-Pt $\left(\mathbf{P E t}_{3}\right)_{2}(\mathbf{B r})\left(\right.$ 1,4-naphthyl) 1(DiPt). A clear orange solution of $\mathrm{Pt}\left(\mathrm{PEt}_{3}\right)_{4}$ (19.5 mg, $29.2 \mu \mathrm{mol})$ in THF $(\sim 0.6 \mathrm{~mL})$ was added to a clear pale yellow solution of $1,4-$ dibromonaphthalene ${ }^{41}(4.1 \mathrm{mg}, 14 \mu \mathrm{mol})$ dissolved in THF $(\sim 0.6 \mathrm{~mL})$. The resulting clear orange solution was stirred overnight at $128{ }^{0} \mathrm{C}$ during which time it turned a pale yellow. The mixture was cooled to room temperature and the volatiles were removed in vacuo to give a pale yellow solid. The solid was washed with $2 \mathrm{X} \sim 0.5 \mathrm{~mL}$ cold hexane and dried in vacuo to yield $10.5 \mathrm{mg}$ off-white $\mathbf{1}(\mathrm{DiPt})(64 \%)$.

${ }^{31} \mathrm{P}\left\{{ }^{1} \mathrm{H}\right\}$ NMR $\left(101 \mathrm{MHz}, \mathrm{CDCl}_{3}\right): 11.65$ (s with satellites, $\left.J_{\mathrm{PtP}}=2778 \mathrm{~Hz}\right) ;(101 \mathrm{MHz}$, THF): $11.95\left(J_{\mathrm{PtP}}=2783 \mathrm{~Hz}\right) ;\left(101 \mathrm{MHz}, \mathrm{C}_{6} \mathrm{D}_{6}\right): 11.73\left(J_{\mathrm{PtP}}=2781 \mathrm{~Hz}\right)$. 
${ }^{1} \mathrm{H}$ NMR (500 MHz, $\left.\mathrm{C}_{6} \mathrm{D}_{6}\right): 8.86-8.84\left(\mathrm{~m}, J_{\mathrm{HH}}=3.50 \mathrm{~Hz}, 2 \mathrm{H}\right), 7.33-7.30$ (asymmetric $\mathrm{m}, J_{\mathrm{HH}}=3.70 \mathrm{~Hz}, 4 \mathrm{H}$ ), 1.64 (asymmetric 9 line pattern, $12 \mathrm{H}, \underline{\mathrm{CH}_{2}} \mathrm{CH}_{3}$ ), 1.51 (asymmetric 9 line pattern, $12 \mathrm{H}, \underline{\mathrm{CH}_{2}} \mathrm{CH}_{3}$ ), 0.94 (app quintet, $J=7.90 \mathrm{~Hz}, 36 \mathrm{H}, \mathrm{CH}_{2} \underline{\mathrm{CH}_{3}}$ ).

Di-trans-Pt( $\left(\mathbf{P E t}_{3}\right)_{2}(\mathbf{B r})_{3}(\mathbf{1}$,4-naphthyl) 2(DiPt). This synthesis was carried out in air and the complex was not isolated. To a $5.6 \mathrm{mg}$ of $\mathbf{1}(\mathrm{DiPt})(4.9 \mu \mathrm{mol})$ in $\mathrm{CDCl}_{3}(\sim 0.6$ $\mathrm{mL}), \sim 0.03 \mathrm{~mL}$ of $1.44 \mathrm{M}$ bromine $(0.08 \mathrm{~mL}, 249 \mathrm{mg}, 1.6 \mathrm{mmol})$ in $\mathrm{CDCl}_{3}$ was added drop-wise resulting in a red clear solution of $\mathbf{2}(\mathrm{DiPt})$.

${ }^{31} \mathrm{P}$ NMR $\left(101 \mathrm{MHz}, \mathrm{CDCl}_{3}\right):-8.50$ (s with satellites, $J_{\mathrm{PtP}}=1631 \mathrm{~Hz}$ ).

${ }^{1} \mathrm{H} \mathrm{NMR}\left(500 \mathrm{MHz}, \mathrm{CDCl}_{3}\right): 8.79-8.77\left(\mathrm{~m}, J_{\mathrm{HH}}=3.0 \mathrm{~Hz}, 2 \mathrm{H}\right), 7.76$ (s with satellites, $\left.J_{P t H}=38.50 \mathrm{~Hz}, 2 \mathrm{H}\right), 7.30-7.27\left(\mathrm{~m}, J_{\mathrm{HH}}=3.50 \mathrm{~Hz}, 2 \mathrm{H}\right), 2.34-2.33\left(\mathrm{~m}, 24 \mathrm{H}, \underline{\mathrm{CH}_{2}} \mathrm{CH}_{3}\right)$, 1.05 (app quintet, $J=7.50 \mathrm{~Hz}, 36 \mathrm{H}, \mathrm{CH}_{2} \underline{\mathrm{CH}}_{3}$ ).

trans-Pt(PEt3 $)_{2}(\mathrm{Br})_{3}(7,4-d i b r o m o-1-n a p h t h y l) \quad 2(\mathrm{BrNapBr}) \quad$ and di-trans$\mathbf{P t}_{(}\left(\mathbf{P E t}_{3}\right)_{2}(\mathbf{B r})_{3}(6,7-d i b r o m o-1,4-n a p h t h y l)$ 2(DiBrPt). This synthesis was carried out in air. To a $54 \mathrm{mg}$ mixture of containing $44 \%$ (BrNap) (24 mg, $33 \mu$ moles) and $56 \%$ 1(DiPt) (30 mg, $26 \mu$ moles) (ratios are based on $\left.{ }^{31} \mathrm{P} \mathrm{NMR}\right)$ in $\mathrm{CDCl}_{3}(\sim 2 \mathrm{~mL})$, added $\sim 6$ $\mathrm{g} \mathrm{Br}_{2}$ (20 moles). The volatiles were removed in vacuo to yield a red oily residue. This was dissolved in $\mathrm{CH}_{2} \mathrm{Cl}_{2}(\sim 2 \mathrm{~mL})$ and layered with $\mathrm{Et}_{2} \mathrm{O}(\sim 2 \mathrm{~mL})$ to yield red and orange crystals. The red and orange crystals were separated manually to yield $15 \mathrm{mg}$ of 2(BrNapBr) $(47 \%)$ and $26 \mathrm{mg}$ of $\mathbf{2}(\mathrm{DiBrPt})(62 \%)$ respectively. These crystals were used for single x-ray crystallography as well. 


\section{2(BrNapBr) (Red)}

${ }^{31} \mathrm{P}$ NMR $\left(101 \mathrm{MHz}, \mathrm{C}_{6} \mathrm{D}_{6}\right):-9.24\left(J_{\mathrm{PtP}}=1599 \mathrm{~Hz}\right)$.

${ }^{1} \mathrm{H}$ NMR $\left(250 \mathrm{MHz}, \mathrm{CDCl}_{3}\right): 9.58\left(\mathrm{~d}, J_{\mathrm{HH}}=1.9 \mathrm{~Hz}, 1 \mathrm{H}, \mathrm{H} 8\right), 8.30$ (d with satellites, $J_{\mathrm{PtH}}$ $=47.8 \mathrm{~Hz}, 1 \mathrm{H}, \mathrm{H} 2), 8.09\left(\mathrm{~d}, J_{\mathrm{HH}}=9.0, \mathrm{~Hz}, 1 \mathrm{H}, \mathrm{H} 3\right), 7.33\left(\mathrm{dd}, J_{\mathrm{HH}}=9.0, \mathrm{~Hz}, J_{\mathrm{HH}}=1.9\right.$ $\mathrm{Hz}, 1 \mathrm{H}, \mathrm{H} 5), 7.27\left(\mathrm{~d}, J_{\mathrm{HH}}=8.4,1 \mathrm{H}, \mathrm{H} 6\right), 2.17\left(\mathrm{~m}, 12 \mathrm{H}, \mathrm{PC}_{2} \mathrm{CH}_{3}\right), 0.75\left(\right.$ app q, $J_{\mathrm{HH}}=$ $\left.7.9 \mathrm{~Hz}, 18 \mathrm{H}, \mathrm{PCH}_{2} \mathrm{CH}_{3}\right)$.

\section{2(DiBrPt) (Orange)}

${ }^{31}$ P NMR (101 MHz, $\left.\mathrm{C}_{6} \mathrm{D}_{6}\right):-9.32\left(J_{\mathrm{PtP}}=1613 \mathrm{~Hz}\right)$.

${ }^{1} \mathrm{H}$ NMR (250 MHz, $\mathrm{C}_{6} \mathrm{D}_{6}$ ): 9.60 (s, 2H, H8 and H5), 8.14 (s satellites, $J_{\mathrm{PtH}}=19.1 \mathrm{~Hz}$, $2 \mathrm{H}, \mathrm{H} 2, \mathrm{H} 3), 2.32\left(\mathrm{~m}, 12 \mathrm{H}, \mathrm{PC}_{2} \mathrm{CH}_{3}\right), 0.87\left(\operatorname{app~q}, J_{\mathrm{HH}}=7.9 \mathrm{~Hz}, 18 \mathrm{H}, \mathrm{PCH}_{2} \underline{\mathrm{C}}_{3}\right)$.

trans-Pt(PEt $)_{2}(\mathbf{B r})$ (2-naphthyl) 1(2-Nap). A clear orange solution of $\mathrm{Pt}\left(\mathrm{PEt}_{3}\right)_{4}(446.2$ $\mathrm{mg}, 0.6682 \mathrm{mmol})$ in THF ( 9 mL) was added to a colorless THF ( 6 mL) solution of 2bromonaphthalene $(139.9 \mathrm{mg}, 0.6756 \mathrm{mmol})$. The resulting clear orange solution was stirred for $8 \mathrm{~h}$ at $120{ }^{\circ} \mathrm{C}$ in a sealed tube during which time it turned almost colorless. The mixture was cooled to ambient temperature and the volatiles removed in vacuo. The offwhite solid residue was washed with cold hexane $(2 \times 0.5 \mathrm{~mL})$ and dried in vacuo to give $391.9 \mathrm{mg}(92 \%)$ off-white solid product.

${ }^{31} \mathrm{P}$ NMR (101 MHz, $\mathrm{CDCl}_{3}$ or $\mathrm{C}_{6} \mathrm{D}_{6}$ ): 12.8 (s with satellites, $J_{\mathrm{PtP}}=2754 \mathrm{~Hz}$ ).

${ }^{1} \mathrm{H}$ NMR $\left(500 \mathrm{MHz}, \mathrm{CDCl}_{3}\right): 7.72$ (s with satellites, $\left.J_{\mathrm{PtH}}=70.0 \mathrm{~Hz}, 1 \mathrm{H}, \mathrm{H} 1\right), 7.70\left(\mathrm{~d}, J_{\mathrm{HH}}\right.$ $=10.0 \mathrm{~Hz}, 1 \mathrm{H}), 7.61\left(\mathrm{~d}, J_{\mathrm{HH}}=10.0 \mathrm{~Hz}, 1 \mathrm{H}\right), 7.56(\mathrm{dd}$ with satellites partially overlapping other peaks, $\left.J_{\mathrm{PtH}}=60 \mathrm{~Hz}, J_{\mathrm{HH}}=7.5 \& 2.5 \mathrm{~Hz}, 1 \mathrm{H}, \mathrm{H} 3\right), 7.41\left(\mathrm{~d}, J_{\mathrm{HH}}=10.0 \mathrm{~Hz}, 1 \mathrm{H}\right), 7.37$ $\left(\mathrm{td}, J_{\mathrm{HH}}=7.5 \& 2.5 \mathrm{~Hz}, 1 \mathrm{H}\right), 7.32\left(\mathrm{t}, J_{\mathrm{HH}}=7.5 \mathrm{~Hz}, 1 \mathrm{H}\right), 1.67\left(\mathrm{~m}, 12 \mathrm{H}, \mathrm{PCH}_{2} \mathrm{CH}_{3}\right), 1.67$ 
(symmetric seventeen line pattern, $J=3.4 \mathrm{~Hz}, 12 \mathrm{H}, \mathrm{PCH}_{2} \mathrm{CH}_{3}$ ), 1.07 (app quin, $J=7.5$ $\mathrm{Hz}, 18 \mathrm{H}, \mathrm{PCH}_{2} \mathrm{CH}_{3}$ ); (500 MHz, $\left.\mathrm{C}_{6} \mathrm{D}_{6}\right): 8.00$ (s with satellites, $J_{\mathrm{PtH}}=75.0 \mathrm{~Hz}, 1 \mathrm{H}, \mathrm{H} 1$ ), 7.73 (dd with satellites partially overlapping other peaks, $J_{\mathrm{PtH}}=60 \mathrm{~Hz}, J_{\mathrm{HH}}=5.0 \& 1 \mathrm{~Hz}$, $1 \mathrm{H}, \mathrm{H} 3), 7.69\left(\mathrm{t}, J_{\mathrm{HH}}=5.0 \mathrm{~Hz}, 1 \mathrm{H}\right), 7.50\left(\mathrm{~d}, J_{\mathrm{HH}}=10.0 \mathrm{~Hz}, 1 \mathrm{H}\right), 7.30\left(\mathrm{td}, J_{\mathrm{HH}}=5.0 \& 1\right.$ $\mathrm{Hz}, 1 \mathrm{H}), 7.24\left(\mathrm{t}, J_{\mathrm{HH}}=7.5 \mathrm{~Hz}, 1 \mathrm{H}\right), 1.56($ symmetric nineteen line pattern, $J=3.9 \mathrm{~Hz}$, $12 \mathrm{H}, \mathrm{CH}_{2} \mathrm{CH}_{3}$ ), 0.86 (apparent quin, $J=8.8 \mathrm{~Hz}, 18 \mathrm{H}, \mathrm{CH}_{2} \mathrm{CH}_{3}$ ).

trans-Pt $\left(\mathbf{P E t}_{3}\right)_{2}(\mathbf{B r})_{3}(2-$ naphthyl) 2(2-Nap). This synthesis was carried out in air. To $88.2 \mathrm{mg}$ of $\mathbf{1}$ (2-Nap) (0.138 mmol) in $\mathrm{CH}_{2} \mathrm{Cl}_{2}(8 \mathrm{~mL}), 0.71 \mathrm{~mL}$ of $0.19 \mathrm{M}$ bromine $(0.14$ mmol) in $\mathrm{CH}_{2} \mathrm{Cl}_{2}$ was added drop-wise. The resulting solution was covered with $\mathrm{Al}$ foil and stirred for $0.5 \mathrm{~h}$ at room temperature. $\mathrm{CH}_{2} \mathrm{Cl}_{2}(2 \mathrm{~mL})$ was added to the solution whilst removing the stirbar. With the reaction vessel still covered with $\mathrm{Al}$ foil the volatiles were removed in vacuo to give $100.6 \mathrm{mg}$ (91\%) of orange solid 2(2-Nap).

${ }^{31} \mathrm{P}$ NMR $\left(101 \mathrm{MHz}, \mathrm{CDCl}_{3}\right)$ : -8.8 (s with satellites, $\left.J_{\mathrm{PtP}}=1621 \mathrm{~Hz}\right) .{ }^{31} \mathrm{P}$ NMR $(101$ $\mathrm{MHz}, \mathrm{C}_{6} \mathrm{D}_{6}$ ): -9.7 (s with satellites, $J_{\mathrm{PtP}}=1627 \mathrm{~Hz}$ ).

${ }^{1} \mathrm{H}$ NMR (500 MHz, $\mathrm{CDCl}_{3}$ ): 8.48 (d with satellites, $J_{\mathrm{PtH}}=45.0 \mathrm{~Hz}, J_{\mathrm{HH}}=1 \mathrm{~Hz}, 1 \mathrm{H}, \mathrm{H1}$ ), $8.25\left(\mathrm{dd}\right.$ with satellites, $\left.J_{\mathrm{PtH}}=38.5 \mathrm{~Hz}, J_{\mathrm{HH}}=9.3 \& 1.8 \mathrm{~Hz}, 1 \mathrm{H}, \mathrm{H} 3\right), 7.77-7.75(\mathrm{~m}, 1 \mathrm{H})$, 7.72-7.0 (m, 1H), 7.46-7.40 (overlapping $\mathrm{m}, 3 \mathrm{H}), 2.26$ (symmetric nine line pattern, $J=$ 3.7 Hz, $\left.12 \mathrm{H}, \mathrm{PCH}_{2} \mathrm{CH}_{3}\right), 1.05$ (apparent quin, $\left.J=8.0 \mathrm{~Hz}, 18 \mathrm{H}, \mathrm{PCH}_{2} \mathrm{CH}_{3}\right) ;\left(\mathrm{C}_{6} \mathrm{D}_{6}\right): 8.85$ (d with satellites, $\left.J_{\mathrm{PtH}}=43.5 \mathrm{~Hz}, J_{\mathrm{HH}}=1.5 \mathrm{~Hz}, 1 \mathrm{H}, \mathrm{H} 1\right), 8.54$ (dd with satellites, $J_{\mathrm{PtH}}=$ $\left.37.8 \mathrm{~Hz}, J_{\mathrm{HH}}=9.0 \& 2.0 \mathrm{~Hz}, 1 \mathrm{H}, \mathrm{H} 3\right), 7.69\left(\mathrm{~d}, J_{\mathrm{HH}}=7.0 \mathrm{~Hz}, 2 \mathrm{H}\right), 7.64\left(\mathrm{~d}, J_{\mathrm{HH}}=7.0 \mathrm{~Hz}\right.$, $1 \mathrm{H}), 7.40\left(\mathrm{~d}, J_{\mathrm{HH}}=9.0 \mathrm{~Hz}, 1 \mathrm{H}\right), 7.27-7.21(\mathrm{~m}, 2 \mathrm{H}, \mathrm{H} 6$ and $\mathrm{H} 7), 2.10$ (symmetric nine- 
line pattern, $J=3.7 \mathrm{~Hz}, 12 \mathrm{H}, \mathrm{PCH}_{2} \mathrm{CH}_{3}$ ), 0.77 (apparent quin, $J_{\mathrm{HH}}=7.9 \mathrm{~Hz}, 18 \mathrm{H}$, $\mathrm{PCH}_{2} \mathrm{CH}_{3}$ ).

\subsection{Photolysis}

Photolysis of $\mathrm{Pt}($ depe $)(\mathrm{Br})_{4}$ 2(depe) with 1 -hexene at $313 \mathrm{~nm}$ in $\mathrm{CDCl}_{3}$. This was carried out in air. To $2.2 \mathrm{mg}$ of 2 (depe) $(3.1 \mu \mathrm{mol})$ in $\mathrm{d}_{6} \mathrm{DMSO}(1.0 \mathrm{~mL})$ added $50 \mu \mathrm{L} 1$ hexene $(0.40 \mathrm{mmol})$. The NMR tube was capped and sealed with wax film. The tube was irradiated under $313 \mathrm{~nm}$ light for 20 minutes. ${ }^{31} \mathrm{P}(101 \mathrm{MHz})$ and ${ }^{1} \mathrm{H}$ NMR $(250 \mathrm{MHz})$ spectra were recorded. After 10 minutes of irradiation $64 \%$ of 2 (depe) converted to $\mathbf{1}$ (depe). Further 10 minutes of irradiation converted all of the $\mathbf{2}$ (depe) to $\mathbf{1}$ (depe). ${ }^{1} \mathrm{H}$ NMR spectroscopy indicated the formation of bromine addition product 1,2dibromohexane $(\sim 65 \%)$.

Photolysis of trans-Pt(PEt $)_{2}$ (Br $_{3}$ (2-naphthyl) 2(2-Nap). $13.4 \mathrm{mg}$ of 2(2-Nap) was transferred to a quartz NMR tube using a micro spatula. The compound was washed down with $0.50 \mathrm{~mL} \mathrm{CDCl}_{3 .} 30 \mu \mathrm{L}$ of cis-2-hexene was added. The NMR tube containing $0.03 \mathrm{M}$ 2(2-Nap) and 0.46 M cis-2-hexene was capped and sealed with wax film. It was irradiated under the $313 \mathrm{~nm}$ light for 10 minutes, 20 minutes and 1 hour intervals. After each point ${ }^{31} \mathrm{P}$ NMR (101 MHz) and ${ }^{1} \mathrm{H}$ NMR (500 MHz) spectra were taken to monitor the reaction. Totally it was irradiated for 1 hour and 30 minutes after which $23 \%$ of trans$\mathrm{Pt}\left(\mathrm{PEt}_{3}\right)_{2}(\mathrm{Br})$ (1-bromo-2-naphthyl) and $10 \%$ of $\mathbf{1}(1-\mathrm{Nap})$ was formed. There was $62 \%$ of 2(1-Nap) still remaining. There was also a minor (5\%) peak at $8.27 \mathrm{ppm}$. 
Photolysis of trans-Pt( $\left(\mathrm{PEt}_{3}\right)_{2}(\mathrm{Br})_{3}$ (1-naphthyl), 2(1-Nap), with cis-2-hexene $\mathrm{CD}_{2} \mathrm{Cl}_{2}$. These procedures were carried out in a dark room with red lighting. Samples were covered with $\mathrm{Al}$ foil and kept in the dark except for brief exposure to dim light for NMR analysis. $13.1 \mathrm{mg}(16.4 \mu$ moles $)$ sample of $\mathbf{2}(1-\mathrm{Nap})$ was transferred to a quartz NMR tube using a micro spatula. The solid was washed down with $0.5 \mathrm{~mL} \mathrm{CD}{ }_{2} \mathrm{Cl}_{2}$ and $30 \mu \mathrm{L}$ of cis-2-hexene was added. The quartz NMR tube containing 0.031 M 2(1-Nap) and 0.46 M cis-2-hexene, was capped and the top wrapped with parafilm. The tube was irradiated under $313 \mathrm{~nm}$ light initially for $10 \mathrm{~min}$ and then an hour. After each irradiation ${ }^{31} \mathrm{P}(101$ MHz) and ${ }^{1} \mathrm{H}$ NMR (500 MHz) spectra were recorded. After 10 minutes $20 \%$ 1(1-Nap) and $20 \% \mathbf{1}$ (BrNap) were seen with $60 \%$ of 2(1-Nap) still remaining. An hour of irradiation further converted all the 2(1-Nap) to $38 \%$ 1(1-Nap) and $62 \% 1$ (BrNap).

\section{Photolysis of trans-Pt($\left(\mathrm{PEt}_{3}\right)_{2}(\mathrm{Br})_{3}$ (1-naphthyl), 2(1-Nap), with cis-2-hexene $\mathrm{CDCl}_{3}$.} These procedures were carried out in a dark room with red lighting. Samples were covered with $\mathrm{Al}$ foil and kept in the dark except for brief exposure to dim light for NMR analysis. $14.4 \mathrm{mg}(18.0 \mu$ moles $)$ sample of $2(1-\mathrm{Nap})$ was transferred to a quartz NMR tube using a micro spatula. The solid was washed down with $0.5 \mathrm{~mL} \mathrm{CD} \mathrm{Cl}_{2}$ and $30 \mu \mathrm{L}$ (0.24 mmoles) of cis-2-hexene were added. The quartz NMR tube containing $0.034 \mathrm{M}$ 2(1-Nap) and 0.46 M cis-2-hexene, was capped and the top portion wound with parafilm. The tube was irradiated under $313 \mathrm{~nm}$ light initially for $10 \mathrm{~min}$ and then 1.5 hours more. After each irradiation ${ }^{31} \mathrm{P}(101 \mathrm{MHz})$ and ${ }^{1} \mathrm{H}$ NMR $(500 \mathrm{MHz})$ spectra were recorded. After 10 minutes $27 \%$ 1(1-Nap) and $17 \%$ 1(BrNap) was seen with $60 \%$ of 2(1-Nap) still 
remaining. 1.5 hours more irradiation further converted all the $2(1-\mathrm{Nap})$ to $55 \% \mathbf{1}(1-$ Nap) and $45 \%$ 1(BrNap).

\section{Photolysis of trans-Pt( $\left.\operatorname{PEt}_{3}\right)_{2}(\mathrm{Br})_{3}(4-\mathrm{BrNap}) 2(\mathrm{BrNap})$ with cis-2-hexene at $313 \mathrm{~nm}$ in}

CDCl 3 . Inside the drybox, 2(BrNap) $(30.6 \mathrm{mg}, 34.9 \mu \mathrm{mol})$ was dissolved in $\mathrm{CDCl}_{3}$ to make $5.00 \mathrm{~mL}$ of solution. (The $\mathrm{CDCl}_{3}$ had been purified by treatment with $\mathrm{Cl}_{2}$ followed by refluxing under a $\mathrm{N}_{2}$ stream and vacuum transfer.) A $0.50 \mathrm{~mL}$ aliquot $(3.5 \mu \mathrm{mol}, 6.6$ $\mathrm{mM})$ of this solution was syringed into a quartz NMR tube. Cis-2-hexene (31 $\mu \mathrm{L}, 0.25$ mmol) was added to the NMR tube. The NMR tube was capped and sealed with wax film. The tube was irradiated under $313 \mathrm{~nm}$ light for $10 \mathrm{~min}$ after which ${ }^{31} \mathrm{P}(101 \mathrm{MHz})$ and ${ }^{1} \mathrm{H}$ NMR (250 MHz) spectra were recorded. All the 2(BrNap) converted to $\mathbf{1}$ (BrNap). ${ }^{1} \mathrm{H}$ NMR spectroscopy indicated the formation of the anti-addition product $(96 \%)$, a racemic mixture of $(2 \mathrm{R}, 3 \mathrm{~S})$ - and $(2 \mathrm{~S}, 3 \mathrm{R})-2,3$-dibromohexane. ${ }^{46}$

Photolysis of trans-Pt( $\left(\mathrm{PEt}_{3}\right)_{2}(\mathrm{Br})_{3}(4-\mathrm{BrNap}) 2(\mathrm{BrNap})$ with 1 -hexene at $313 \mathrm{~nm}$ in CDCl 3. 2(BrNap) $(4.2 \mathrm{mg}, 4.8 \mu \mathrm{mol})$ was dissolved in $0.5 \mathrm{~mL} \mathrm{CDCl}_{3}$. This solution was transferred to a quartz NMR tube. 1-hexene $(50 \mu \mathrm{L}, 0.40 \mathrm{mmol})$ was added to the NMR tube. The NMR tube was capped and sealed with wax film. The tube was irradiated under $313 \mathrm{~nm}$ light for $25 \mathrm{~min}$ after which ${ }^{31} \mathrm{P}(101 \mathrm{MHz})$ and ${ }^{1} \mathrm{H}$ NMR $(250 \mathrm{MHz})$ spectra were recorded. All the 2(BrNap) converted to $\mathbf{1}(\mathrm{BrNap}) .{ }^{1} \mathrm{H}$ NMR spectroscopy indicated the formation of the bromine addition product 1,2-dibromohexane $(88 \%) .^{76}$ 
Photolysis of trans-Pt(PEt $)_{2}\left(\mathrm{Br}_{3}(4-\mathrm{BrNap})\right.$ 2(BrNap) with $\mathrm{TME}$ at $313 \mathrm{~nm}$ in $\mathbf{C D C l}_{3}$. Inside the drybox, $\mathbf{2}(\mathrm{BrNap})(30.6 \mathrm{mg}, 34.9 \mu \mathrm{mol})$ was dissolved in $\mathrm{CDCl}_{3}$ to make $5.00 \mathrm{~mL}$ of solution. (The $\mathrm{CDCl}_{3}$ had been purified by treatment with $\mathrm{Cl}_{2}$ followed by refluxing under a $\mathrm{N}_{2}$ stream and vacuum transfer). A $0.50 \mathrm{~mL}$ aliquot $(3.49 \mu \mathrm{moles}$, $6.98 \mathrm{mM}$ ) of this solution was syringed into three quartz NMR tubes. $1 \mu \mathrm{L}$ ( $8 \mu$ moles), 3 $\mu \mathrm{L}(25 \mu$ moles $)$ and $8 \mu \mathrm{L}(67 \mu$ moles $)$ aliquots of TME was added to each tube. The quartz NMR tubes, containing $6.96 \mathrm{mM}, 6.94 \mathrm{mM}$ and $6.87 \mathrm{mM}$ of 2 (BrNap) and 17 $\mathrm{mM}, 50 \mathrm{mM}$ and $132 \mathrm{mM}$ of TME, respectively, were capped and sealed with wax film. The tubes were irradiated under $313 \mathrm{~nm}$ light for $10 \mathrm{~min}, 15 \mathrm{~min}$ and $15 \mathrm{~min}$ after which ${ }^{31} \mathrm{P}(101 \mathrm{MHz})$ and ${ }^{1} \mathrm{H}$ NMR $(250 \mathrm{MHz})$ spectra were recorded. All the 2(BrNap) converted to $\mathbf{1}$ (BrNap) in the case of $50 \mathrm{mM}$ and $132 \mathrm{mM}$ TME concentrations. With only $52 \%$ of 2 (BrNap) conversion to $\mathbf{1}(\mathrm{BrNap})$ all the TME was consumed in the case of the $17 \mathrm{mM}$ TME concentration. ${ }^{1} \mathrm{H}$ NMR spectroscopy indicated the formation of the addition product 2,3-dimethyl-2,3-dibromobutane (3), ${ }^{49}$ 1-bromo-2,3-dimethyl-2-butene (4) ${ }^{50,51}$ and 2-bromo-2,3-dimethylbutane (5). ${ }^{49}$ Yield of the addition product decreased with increasing TME concentrations.

\section{Photolysis of trans-Pt( $\left.\operatorname{PEt}_{3}\right)_{2}(\mathrm{Br})_{3}(4-\mathrm{BrNap}) 2(\mathrm{BrNap})$ with 1 -hexene at $380 \mathrm{~nm}$ in} $\mathbf{C D C l}_{3}$. Inside the drybox, 2 (BrNap) $(31.2 \mathrm{mg}, 35.6 \mu \mathrm{mol})$ was dissolved in $\mathrm{CDCl}_{3}$ to make $5.00 \mathrm{~mL}$ of solution. (The $\mathrm{CDCl}_{3}$ had been purified by refluxing with $\mathrm{MgSO}_{4}$ and then passing through activated neutral alumina.) A $0.50 \mathrm{~mL}$ aliquot $(3.6 \mu \mathrm{mol}, 7.1 \mathrm{mM})$ of this solution was syringed into a quartz NMR tube. 1-hexene $(30 \mu \mathrm{L}, 0.24 \mathrm{mmol})$ was added to the NMR tube and it was then capped and sealed with wax film. The tube was 
irradiated under $380 \mathrm{~nm}$ with a $24 \mathrm{LED}$ light source using $30 \mathrm{~mA}$ current. Using ${ }^{31} \mathrm{P}(101$ $\mathrm{MHz})$ and ${ }^{1} \mathrm{H}$ NMR $(250 \mathrm{MHz})$ the photolysis was monitored. Based on the ${ }^{31} \mathrm{P}$ NMR 96 $\%$ of $\mathbf{2}$ (BrNap) converted to $\mathbf{1}$ (BrNap) after $98 \mathrm{~min}$ of irradiation. (Ratios are based on ${ }^{31}$ P NMR).

Photolysis of trans-Pt $\left(\mathrm{PEt}_{3}\right)_{2}(\mathrm{Br})_{3}(4-\mathrm{BrNap}) 2(\mathrm{BrNap})$ with 1-hexene in the presence of trans-Pt( $\left(\mathrm{PEt}_{3}\right)_{2}(\mathrm{Br})(4-\mathrm{BrNap}) \mathbf{1}(\mathrm{BrNap})$ at $380 \mathrm{~nm}$ in $\mathbf{C D C l}_{3}$. Inside the drybox, 2(BrNap) $(31.2 \mathrm{mg}, 35.6 \mu \mathrm{mol})$ was dissolved in $\mathrm{CDCl}_{3}$ to make $5.00 \mathrm{~mL}$ of solution. (The $\mathrm{CDCl}_{3}$ had been purified by refluxing with $\mathrm{MgSO}_{4}$ and then passing through activated neutral alumina.) A $0.50 \mathrm{~mL}$ aliquot $(3.6 \mu \mathrm{mol}, 7.1 \mathrm{mM})$ of this solution was syringed into a quartz NMR tube containing $3.3 \mathrm{mg}(4.6 \mu \mathrm{mol}, 9.2 \mathrm{mM})$ of $\mathbf{1}(\mathrm{BrNap})$ (previously weighed and dissolved in $\mathrm{CH}_{2} \mathrm{Cl}_{2}$, then transferred into the quartz NMR tube and dried in vacuo ). 1-hexene (30 $\mu \mathrm{L}, 0.24 \mathrm{mmol})$ was added to the NMR tube and then it was capped and sealed with wax film. The tube was irradiated under $380 \mathrm{~nm}$ with a 24 LED light source using $30 \mathrm{~mA}$ current. Using ${ }^{31} \mathrm{P}(101 \mathrm{MHz})$ and ${ }^{1} \mathrm{H} \mathrm{NMR}(250 \mathrm{MHz})$ the photolysis was monitored. Based on the ${ }^{31} \mathrm{P}$ NMR $94 \%$ of $2(\mathrm{BrNap})$ converted to $\mathbf{1}\left(\right.$ BrNap) after $175 \mathrm{~min}$ of irradiation. (Ratios are based on $\left.{ }^{31} \mathrm{P} \mathrm{NMR}\right)$.

Photolysis of trans-Pt( $\left(\mathrm{PEt}_{3}\right)_{2}(\mathrm{Br})_{3}(4-\mathrm{BrNap})$ 2(BrNap) with 2,3-dimethyl-2-butene (TME) at $313 \mathbf{~ n m}$ in $\mathbf{C D C l}_{3}$. Inside the drybox, 2(BrNap) (31.2 $\left.\mathrm{mg}, 35.6 \mu \mathrm{mol}\right)$ was dissolved in $\mathrm{CDCl}_{3}$ to make $5.00 \mathrm{~mL}$ of solution. (The $\mathrm{CDCl}_{3}$ had been purified by refluxing with $\mathrm{MgSO}_{4}$ and then passing through activated neutral alumina.) A $0.50 \mathrm{~mL}$ aliquot $(3.6 \mu \mathrm{mol}, 7.1 \mathrm{mM})$ of this solution was syringed into a quartz NMR tube. 2,3- 
dimethyl-2-butene ( $30 \mu \mathrm{L}, 0.25 \mathrm{mmol}$ ) was added to the NMR tube and it was then capped and sealed with wax film. The tube was irradiated under $313 \mathrm{~nm}$ light. Using ${ }^{31} \mathrm{P}$ (101 MHz) and ${ }^{1} \mathrm{H}$ NMR (250 MHz) the photolysis was monitored. Based on the ${ }^{31} \mathrm{P}$ NMR $93 \%$ of 2 (BrNap) converted to $\mathbf{1}$ (BrNap) after 6.5 min of irradiation. (Ratios are based on ${ }^{31} \mathrm{P}$ NMR).

Photolysis of trans-Pt(PEt $)_{2}(\mathrm{Br})_{3}(4-B r N a p) 2(B r N a p)$ with 1-hexene at $313 \mathrm{~nm}$ in $\mathbf{C D C l}_{3}$. Inside the drybox, $\mathbf{2}(\mathrm{BrNap})(31.2 \mathrm{mg}, 35.6 \mu \mathrm{mol})$ was dissolved in $\mathrm{CDCl}_{3}$ to make $5.00 \mathrm{~mL}$ of solution. (The $\mathrm{CDCl}_{3}$ had been purified by refluxing with $\mathrm{MgSO}_{4}$ and then passing through activated neutral alumina.) A $0.50 \mathrm{~mL}$ aliquot $(3.6 \mu \mathrm{mol}, 7.1 \mathrm{mM})$ of this solution was syringed into a quartz NMR tube. 1-hexene $(30 \mu \mathrm{L}, 0.24 \mathrm{mmol})$ was added to the NMR tube and it was then capped and sealed with wax film. The tube was irradiated under $313 \mathrm{~nm}$ light. Using ${ }^{31} \mathrm{P}(101 \mathrm{MHz})$ and ${ }^{1} \mathrm{H} \mathrm{NMR}(250 \mathrm{MHz})$ the photolysis was monitored. Based on the ${ }^{31} \mathrm{P}$ NMR $96 \%$ of 2 (BrNap) converted to $\mathbf{1}\left(\right.$ BrNap) after 13 min of irradiation. (Ratios are based on $\left.{ }^{31} \mathrm{P} N M R\right)$.

Photolysis of trans-Pt( $\left(\mathrm{PEt}_{3}\right)_{2}(\mathrm{Br})_{3}(4-\mathrm{BrNap}) 2(\mathrm{BrNap})$ with 1 -hexene at $313 \mathrm{~nm}$ in the presence of Oxygen. Inside the drybox, 2(BrNap) $(31.2 \mathrm{mg}, 35.6 \mu \mathrm{mol})$ was dissolved in $\mathrm{CDCl}_{3}$ to make $5.00 \mathrm{~mL}$ of solution. (The $\mathrm{CDCl}_{3}$ had been purified by refluxing with $\mathrm{MgSO}_{4}$ and then passing through activated neutral alumina.) A $0.50 \mathrm{~mL}$ aliquot $(3.6 \mu \mathrm{mol}, 7.1 \mathrm{mM})$ of this solution was syringed into a quartz NMR tube. 1hexene (30 $\mu \mathrm{L}, 0.24 \mathrm{mmol})$ was added to the NMR tube and it was then capped and sealed with wax film. It was taken out of the dry box and exposed to the atmosphere by 
removing the cap. $7 \mathrm{X} \sim 10 \mathrm{~mL}$ of oxygen gas was then syringed into the NMR tube above the solution. It was capped, sealed with wax film and shaken well to mix the solution with oxygen. The tube was irradiated under $313 \mathrm{~nm}$ light. Using ${ }^{31} \mathrm{P}(101 \mathrm{MHz})$ and ${ }^{1} \mathrm{H}$ NMR $(250 \mathrm{MHz})$ the photolysis was monitored. Based on the ${ }^{31} \mathrm{P}$ NMR $94 \%$ of $\mathbf{2}$ (BrNap) converted to $\mathbf{1}$ (BrNap) after $13 \mathrm{~min}$ of irradiation. (Ratios are based on ${ }^{31} \mathrm{P}$ NMR).

\subsection{Low temperature photolysis}

Low temperature photolysis of trans-Pt( $\left(\mathrm{PEt}_{3}\right)_{2}(\mathrm{Br})_{3}(4-\mathrm{BrNap}) 2(\mathrm{BrNap})$ in 2methyltetrahydrofuran at $380 \mathrm{~nm}$. 2(BrNap) $(3.1 \mathrm{mg}, 3.6 \mu \mathrm{mol})$ was dissolved in 0.7 $\mathrm{mL} 2$-methyltetrahydrofuran. This solution was transferred to a quartz NMR tube. The NMR tube was capped and sealed with wax film. The tube was frozen and irradiated at $77 \mathrm{~K}$ under $380 \mathrm{~nm}$ with a $24 \mathrm{LED}$ light source using $30 \mathrm{~mA}$ current. Based on the ${ }^{31} \mathrm{P}$ NMR $4 \%$ of $\mathbf{2}$ (BrNap) converted to $\mathbf{1}($ BrNap) after $3 \mathrm{~h}$ and $40 \mathrm{~min}$ of irradiation. (Ratios are based on $\left.{ }^{31} \mathrm{P} \mathrm{NMR}\right)$.

\section{Low temperature photolysis of trans-Pt($\left(\mathrm{PEt}_{3}\right)_{2}(\mathrm{Br})_{4} \quad 2(\mathrm{Br}) \quad$ in 2 -} methyltetrahydrofuran at $380 \mathrm{~nm}$ and $313 \mathrm{~nm} .2(\mathrm{Br})(<5 \mathrm{mg},<5.8 \mu \mathrm{mol})$ in a quartz NMR tube was dissolved in $0.5 \mathrm{~mL}$ 2-methyltetrahydrofuran. The NMR tube was capped and sealed with wax film. The tube was frozen and irradiated for $15 \mathrm{~h}$ and $30 \mathrm{~min}$ at $77 \mathrm{~K}$ under $380 \mathrm{~nm}$ with a 24 LED light source using $30 \mathrm{~mA}$ current. Then the tube was frozen and irradiated for $1 \mathrm{~h}$ at $77 \mathrm{~K}$ under $313 \mathrm{~nm}$. Using ${ }^{31} \mathrm{P}$ NMR (101 MHz) the photolysis 
was monitored. Based on the ${ }^{31} \mathrm{P}$ NMR after $380 \mathrm{~nm}$ irradiation $33 \%$ of 2 (BrNap) reacted. With further irradiation at $313 \mathrm{~nm}, 35 \%$ of 2 (BrNap) converted to form $27 \%$ of $\mathbf{1}(\mathrm{Br})$ and $7.5 \%$ of an unknown product (4.709 $\mathrm{ppm},{ }^{31} \mathrm{P}$ NMR). (Ratios are based on ${ }^{31} \mathrm{P}$ NMR).

\subsection{Quantum Yield}

Quantum Yield Determinations. Irradiations were performed in $1 \mathrm{~cm}$ quartz cuvettes in the compartment of a Cary $50 \mathrm{UV}-\mathrm{V}$ is spectrometer equipped with a magnetic stirrer and temperature control. A 313 nm Philips (PL-S 9W/01) 9 W lamp, with a 300-380 nm band pass filter, light source was positioned over the sample compartment allowing irradiations through the top of the uncovered cuvette. ${ }^{77}$ The photon flux was measured (iron oxalate actinometry ${ }^{47,48}$ ) before and after each sample irradiation and the average of the before and after measurements was used as the photon flux during the sample irradiation. Sample solution concentrations were sufficiently high to assure complete photon absorption (absorbance $\geq 2$ at the irradiation wavelength) over the $\sim 3 \mathrm{~cm}$ depth of the solution. Reaction progress was monitored by the uv-vis absorbance of the starting Pt(IV) complex over a region where the $\mathrm{Pt}(\mathrm{II})$ product does not absorb and the $\mathrm{Pt}(\mathrm{IV})$ absorbance is $\sim 1$. The absorbance decrease at three wavelengths during 3 runs was used to calculate the quantum yield. 


\subsection{Thermal reactions}

\section{Dark reaction of trans-Pt $\left(\mathrm{PEt}_{3}\right)_{2}(\mathrm{Br})_{3}$ (2-trifluoromethylphenyl) 2(CF $\left.3 \mathbf{P h}\right)$ with 1-}

hexene in $\mathrm{CDCl}_{3}$. Samples were covered with $\mathrm{Al}$ foil and kept in the dark (at room temperature) except for sample preparation and NMR analysis. Inside the dry box, 17.9 mg $\left(21.9 \mu\right.$ moles) of $2\left(\mathrm{CF}_{3} \mathrm{Ph}\right)$ was made up to $5.00 \mathrm{~mL}$ using $\mathrm{CDCl}_{3}$ (treated with $\mathrm{Cl}_{2}$, refluxed under a stream of $\mathrm{N}_{2}$ and vacuum transferred). A $1.00 \mathrm{~mL}$ aliquot ( $4.39 \mu$ moles, $4.33 \mathrm{mM}$ ) of this solution was syringed into three quartz NMR tubes. An aliquot of 1hexene, $12 \mu \mathrm{L}$ (97 $\mu$ moles), $25 \mu \mathrm{L}(0.20 \mathrm{mmol})$ and $50 \mu \mathrm{L}(0.40 \mathrm{mmol})$ was added to each tube. The quartz NMR tubes, containing $4.3 \mathrm{mM}, 4.3 \mathrm{mM}$ and $4.2 \mathrm{mM}$ of $2\left(\mathrm{CF}_{3} \mathrm{Ph}\right)$ and $0.096 \mathrm{M}, 0.19 \mathrm{M}$ and $0.38 \mathrm{M}$ 1-hexene, respectively, were capped and sealed with wax film. ${ }^{31} \mathrm{P}(101 \mathrm{MHz}),{ }^{19} \mathrm{~F}(235 \mathrm{MHz})$ and ${ }^{1} \mathrm{H}(250 \mathrm{MHz})$ NMR spectra were recorded at various time intervals as the reaction progressed at room temperature. Average first order rate constant $\left(\mathrm{k}_{\mathrm{obs}}\right)=1.4(1) \times 10^{-3} \mathrm{~min}^{-1}$.

\section{Dark reaction of trans- $\mathrm{Pt}\left(\mathrm{PEt}_{3}\right)_{2}(\mathrm{Br})_{3}$ (2-trifluoromethylphenyl) $2\left(\mathrm{CF}_{3} \mathrm{Ph}\right)$ with 1-} hexene in $\mathbf{C}_{6} \mathbf{D}_{6}$. Sample was covered with $\mathrm{Al}$ foil and kept in the dark (at room temperature) except for sample preparation and NMR analysis. Inside the dry box, $3.7 \mathrm{mg}$ (4.5 $\mu$ moles) of $2\left(\mathrm{CF}_{3} \mathrm{Ph}\right)$ was made up to $1.00 \mathrm{~mL}$ using $\mathrm{C}_{6} \mathrm{D}_{6}$ (passed through neutral $\mathrm{Al}_{2} \mathrm{O}_{3}$ ). Then this solution was transferred to a quartz NMR tube and $50 \mu \mathrm{L}$ of 1-hexene (0.40 mmol) was added. The quartz NMR tube containing $4.3 \mathrm{mM}$ of $2\left(\mathrm{CF}_{3} \mathrm{Ph}\right)$ and 0.38

M 1-hexene was capped and sealed with wax film. ${ }^{31} \mathrm{P}(101 \mathrm{MHz}),{ }^{19} \mathrm{~F}(235 \mathrm{MHz})$ and ${ }^{1} \mathrm{H}$ (250 MHz) NMR spectra were recorded at various time intervals to monitor the reaction 
progress at room temperature. After four days, only $\sim 5 \%$ of $2\left(\mathrm{CF}_{3} \mathrm{Ph}\right)$ converted to $\mathbf{1}\left(\mathrm{CF}_{3} \mathrm{Ph}\right)$.

\subsection{Bromination competition experiments}

Bromine addition to trans-Pt( $\left(\mathrm{PEt}_{3}\right)_{2}(\mathrm{Br})(4-\mathrm{BrNap}) 1(\mathrm{BrNap})$ in the presence of 1hexene in $\mathbf{C D C l}_{\mathbf{3}}$. This addition was carried out in air. To $12.7 \mathrm{mg}$ of $\mathbf{1}$ (BrNap) (17.7 $\mu \mathrm{mol})$ in $\mathrm{CDCl}_{3}(0.6 \mathrm{~mL})$ was added $2.2 \mu \mathrm{L}$ 1-hexene $(18 \mu \mathrm{mol})$. Then under constant stirring, $20 \mu \mathrm{L}$ of $100 \mathrm{mM}$ bromine $(5 \mu \mathrm{L}, 20 \mathrm{mg}, 100 \mu \mathrm{mol})$ in $\mathrm{CDCl}_{3}$ was added. Color changed from colorless to pale yellow. The solution was transferred to a NMR tube, capped and sealed with wax film. Based on the ${ }^{31}$ P NMR $8 \%$ of $\mathbf{1}$ (BrNap) converted to 2(BrNap). ${ }^{1} \mathrm{H}$ NMR spectroscopy indicated no formation of the anti-addition product, 1,2-dibromohexane. (Ratios are based on ${ }^{31} \mathrm{P}$ NMR).

Bromine addition to trans-Pt($\left(\mathrm{PEt}_{3}\right)_{2}(\mathrm{Br})(4-\mathrm{BrNap}) 1(\mathrm{BrNap})$ in the presence of excess 1-hexene in $\mathbf{C D C l}_{3}$. This addition was carried out in air. To $5.7 \mathrm{mg}$ of $\mathbf{1}$ (BrNap) (7.9 $\mu \mathrm{mol})$ in $\mathrm{CDCl}_{3}(0.6 \mathrm{~mL})$ was added $10 \mu \mathrm{L}$ 1-hexene $(81 \mu \mathrm{mol})$. Then under constant stirring, $8 \mu \mathrm{L}$ of $100 \mathrm{mM}$ bromine $(5 \mu \mathrm{L}, 20 \mathrm{mg}, 100 \mu \mathrm{mol})$ in $\mathrm{CDCl}_{3}$ was added. Color changed from colorless to pale yellow. The solution was transferred to a NMR tube, capped and sealed with wax film. Using ${ }^{31} \mathrm{P}(101 \mathrm{MHz})$ and ${ }^{1} \mathrm{H}$ NMR (250 $\mathrm{MHz}$ ) bromine addition was monitored. Based on the ${ }^{31} \mathrm{P}$ NMR $7 \%$ of $\mathbf{1}$ (BrNap) converted to 2(BrNap). ${ }^{1} \mathrm{H}$ NMR spectroscopy indicated no formation of the anti-addition product, 1,2-dibromohexane. (Ratios are based on ${ }^{31} \mathrm{P}$ NMR). 
$\mathrm{Br}_{2}$ addition to a 1:1 mixture of 1-hexene and trans-3-hexene. Inside the glovebox, 1hexene $(0.02 \mathrm{~mL}, 0.2 \mathrm{mmol})$ and trans-3-hexene $(0.02 \mathrm{~mL}, 0.2 \mathrm{mmol})$ were syringed into a vial containing $0.6 \mathrm{~mL} \mathrm{CDCl} 3$. The vial was taken out from the drybox. Then under constant stirring, $150 \mu \mathrm{L}$ of $0.1 \mathrm{M}$ bromine $(5 \mu \mathrm{L}, 20 \mathrm{mg}, 100 \mu \mathrm{mol}) \mathrm{CDCl}_{3}$ solution was added to the vial containing the alkene mixture. ${ }^{1} \mathrm{H}$ NMR spectroscopy of the resulting solution indicated the formation of 3,4-trans-dibromohexane.

Photolysis of trans-Pt $\left(\mathrm{PEt}_{3}\right)_{2}(\mathrm{Br})_{3}(4-\mathrm{BrNap})$ 2(BrNap) with 1:1 mixture of trans-3hexene and 1-hexene at $\mathbf{3 1 3} \mathbf{~} \mathbf{m}$ in $\mathbf{C D C l}_{3}$. Inside the drybox, 2(BrNap) (3.1 $\mathrm{mg}, 3.6$ $\mu \mathrm{mol})$ was dissolved in $0.6 \mathrm{~mL} \mathrm{CDCl}_{3}$ in a vial. Then 1-hexene $(0.02 \mathrm{~mL}, 0.2 \mathrm{mmol})$ and trans-3-hexene $(0.02 \mathrm{~mL}, 0.2 \mathrm{mmol})$ were syringed into the vial. The solution was transferred into a quart NMR tube, capped and sealed with wax film and taken out of the drybox. The tube was irradiated under $313 \mathrm{~nm}$ light. Using ${ }^{31} \mathrm{P}(101 \mathrm{MHz})$ and ${ }^{1} \mathrm{H}$ NMR (250 MHz) the photolysis was monitored. Based on ${ }^{31} \mathrm{P}$ NMR, 2(BrNap) converted to 1(BrNap) after $10 \mathrm{~min}$ of irradiation. ${ }^{1} \mathrm{H}$ NMR spectroscopy of the resulting solution indicated formation of 3,4-trans-dibromohexane. 


\subsection{Uv-visible spectroscopy}

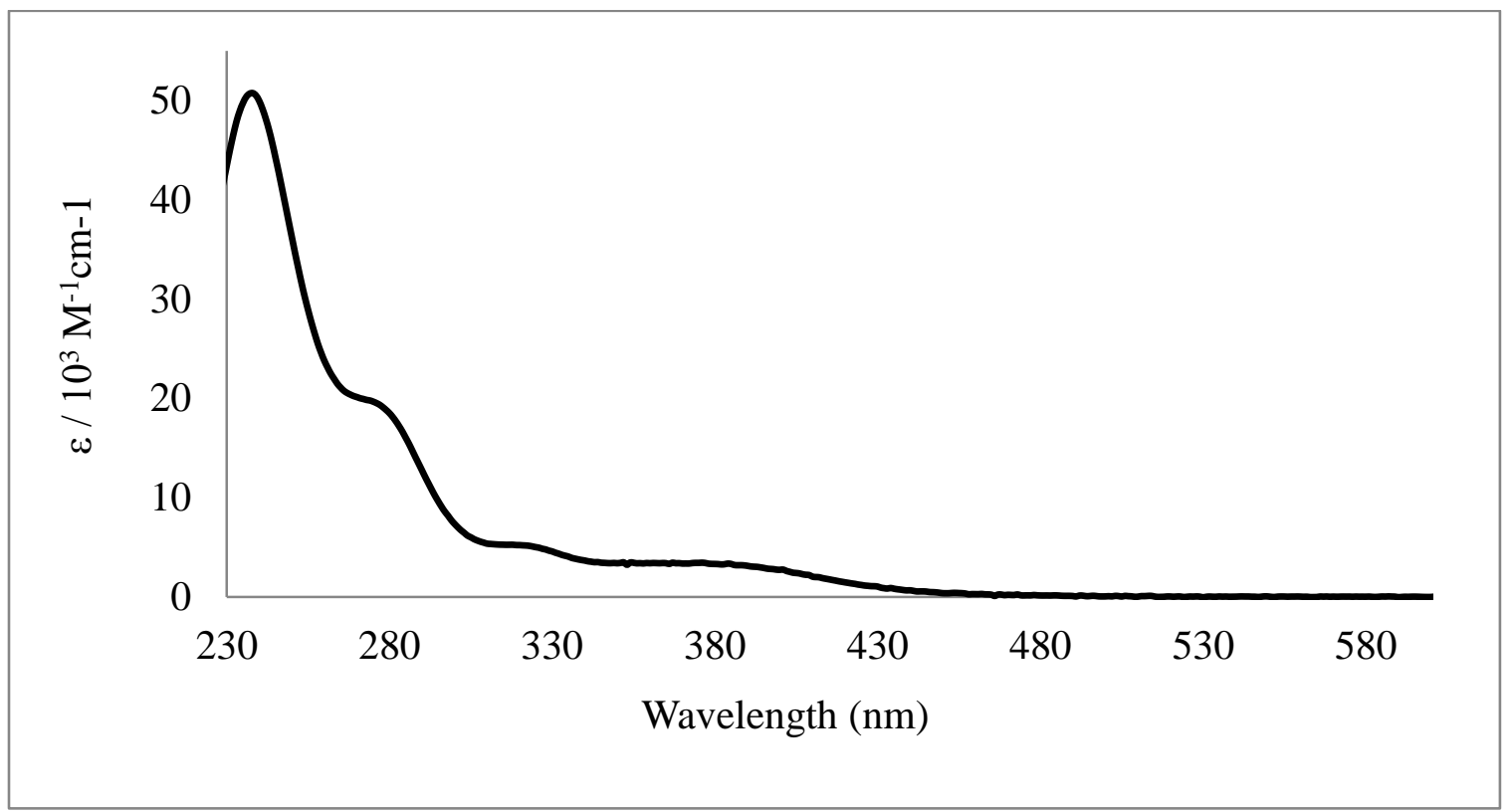

Figure 4.8.1 Electronic absorption spectrum of trans- $\mathrm{Pt}\left(\mathrm{PEt}_{3}\right)_{2}(\mathrm{Br})_{3}(1$-phenyl $) 2(\mathrm{Ph})$ in $\mathrm{CH}_{2} \mathrm{Cl}_{2}$.

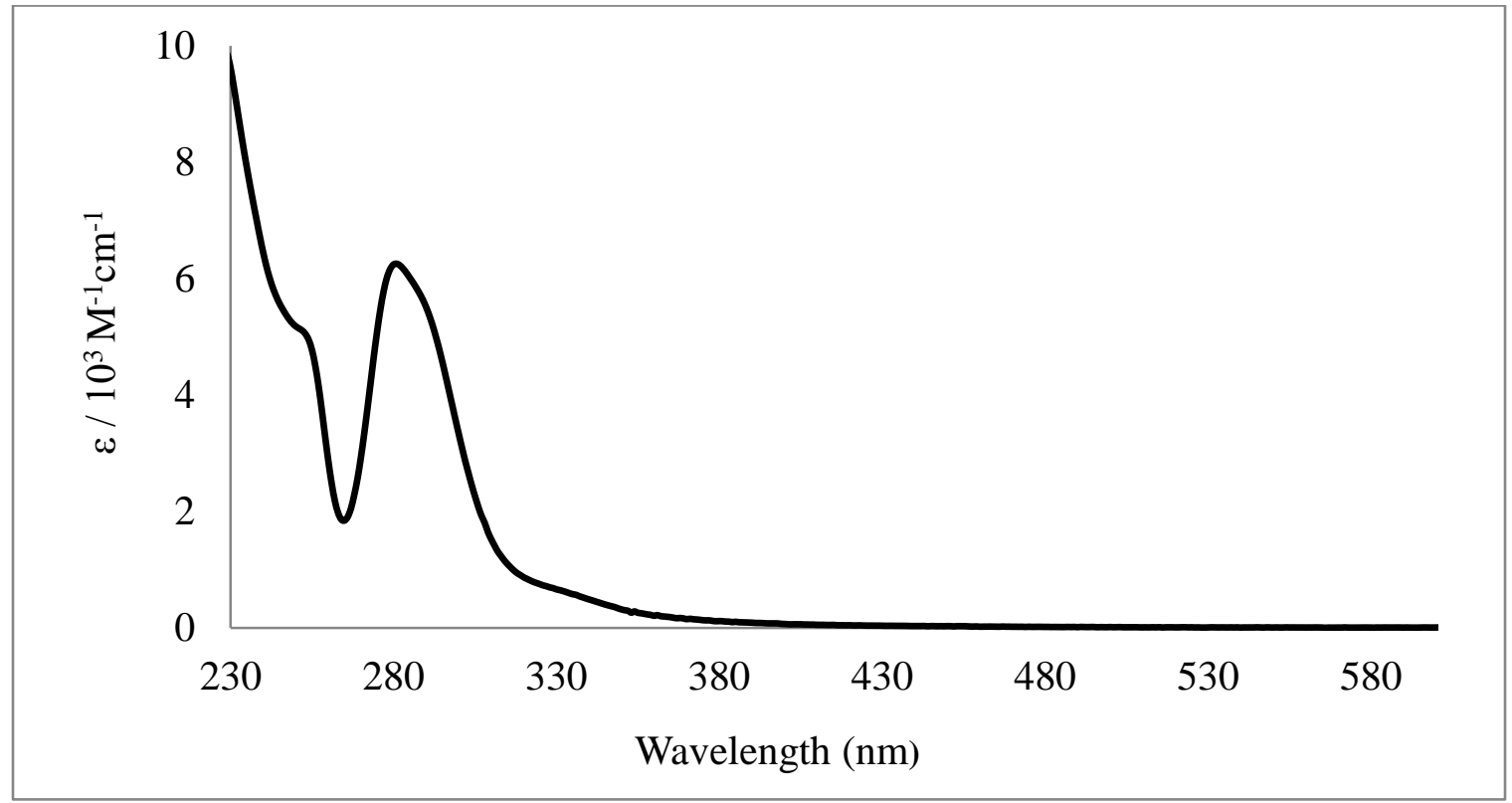

Figure 4.8.2. Electronic absorption spectrum of trans- $\mathrm{Pt}\left(\mathrm{PEt}_{3}\right)_{2}(\mathrm{Br})_{2} \mathbf{1}(\mathrm{Br})$ in $\mathrm{CH}_{2} \mathrm{Cl}_{2}$. 


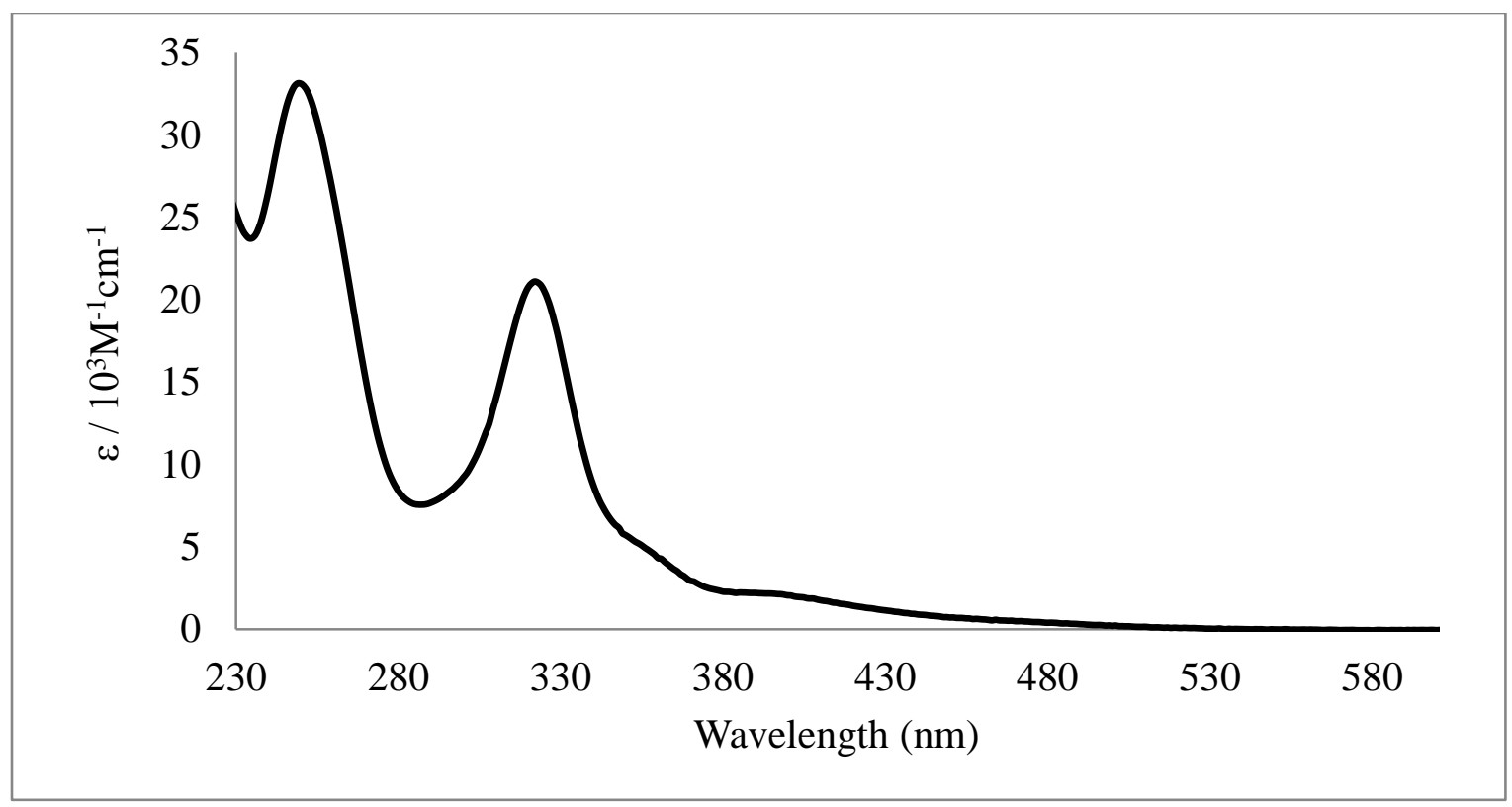

Figure 4.8.3. Electronic absorption spectrum of trans $-\mathrm{Pt}\left(\mathrm{PEt}_{3}\right)_{2}(\mathrm{Br})_{4} 2(\mathrm{Br})$ in $\mathrm{CH}_{2} \mathrm{Cl}_{2}$.

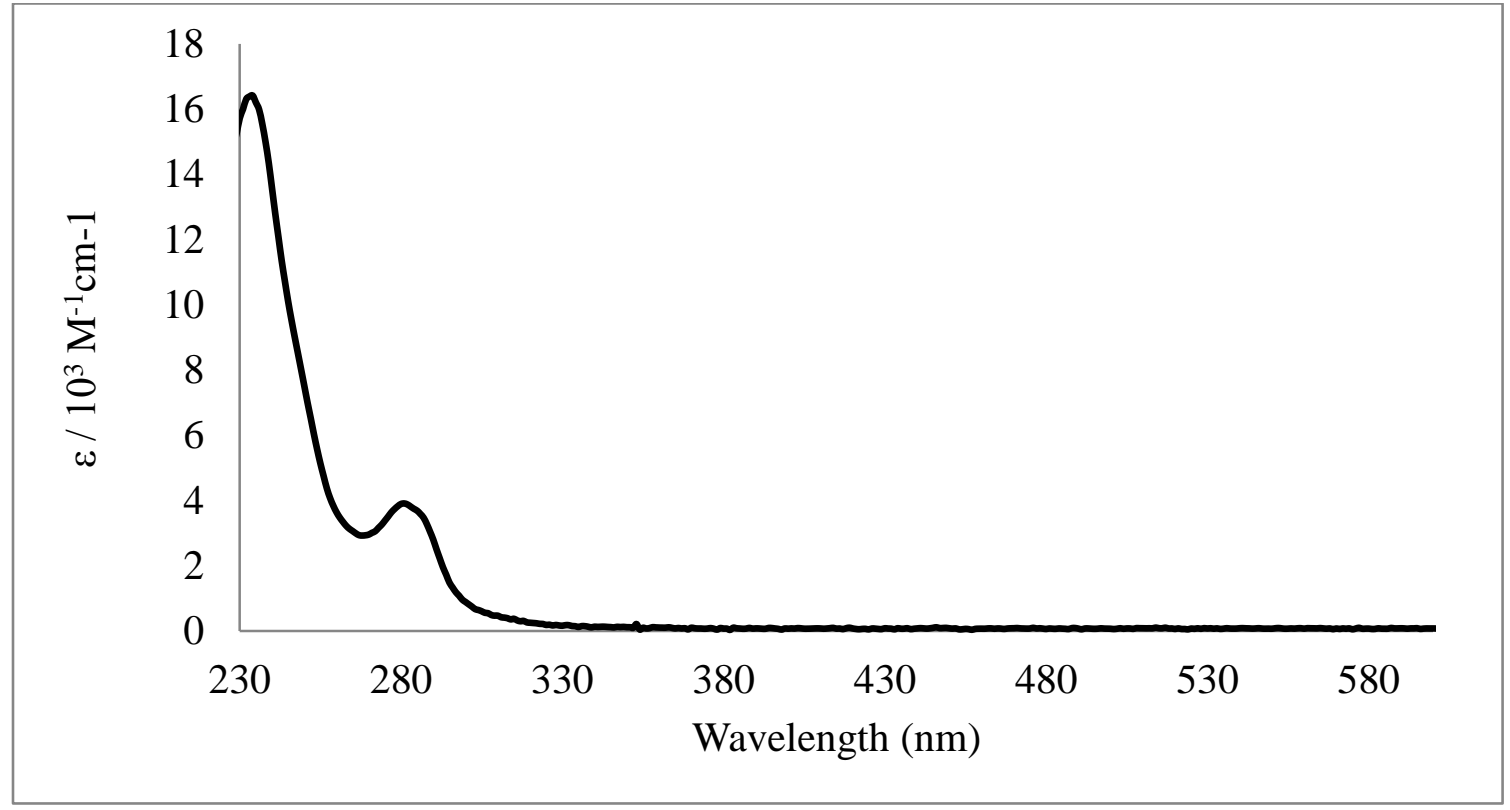

Figure 4.8.4. Electronic absorption spectrum of trans- $\mathrm{Pt}\left(\mathrm{PEt}_{3}\right)_{2}(\mathrm{Br})(2-$ (trifluoromethy)phenyl) $\mathbf{1}\left(\mathrm{CF}_{3} \mathrm{Ph}\right)$ in $\mathrm{CH}_{2} \mathrm{Cl}_{2}$. 


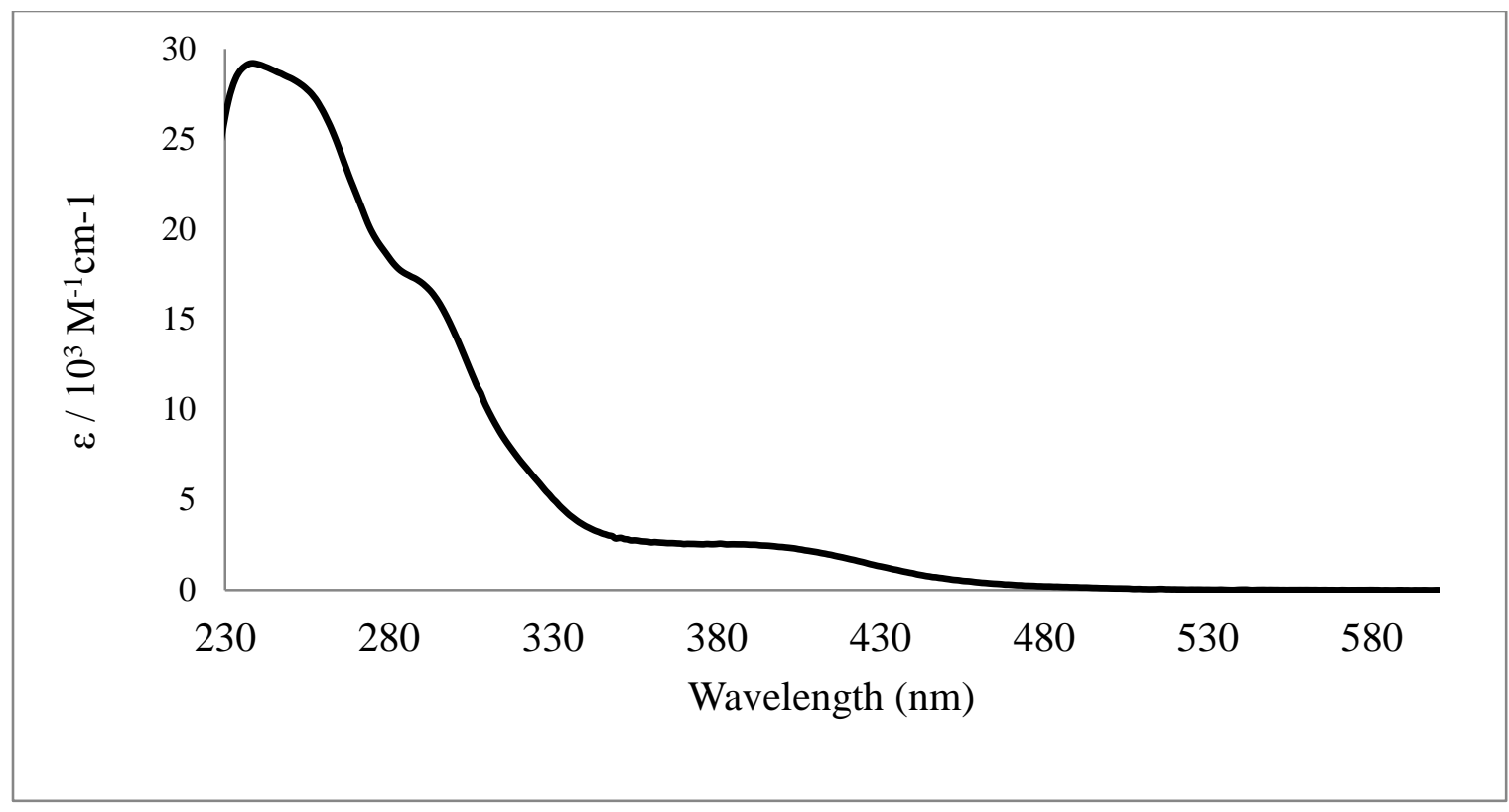

Figure 4.8.5. Electronic absorption spectrum of trans- $\mathrm{Pt}\left(\mathrm{PEt}_{3}\right)_{2}(\mathrm{Br})_{3}(2-$ (trifluoromethy)phenyl) 2(CF3Ph) in $\mathrm{CH}_{2} \mathrm{Cl}_{2}$.

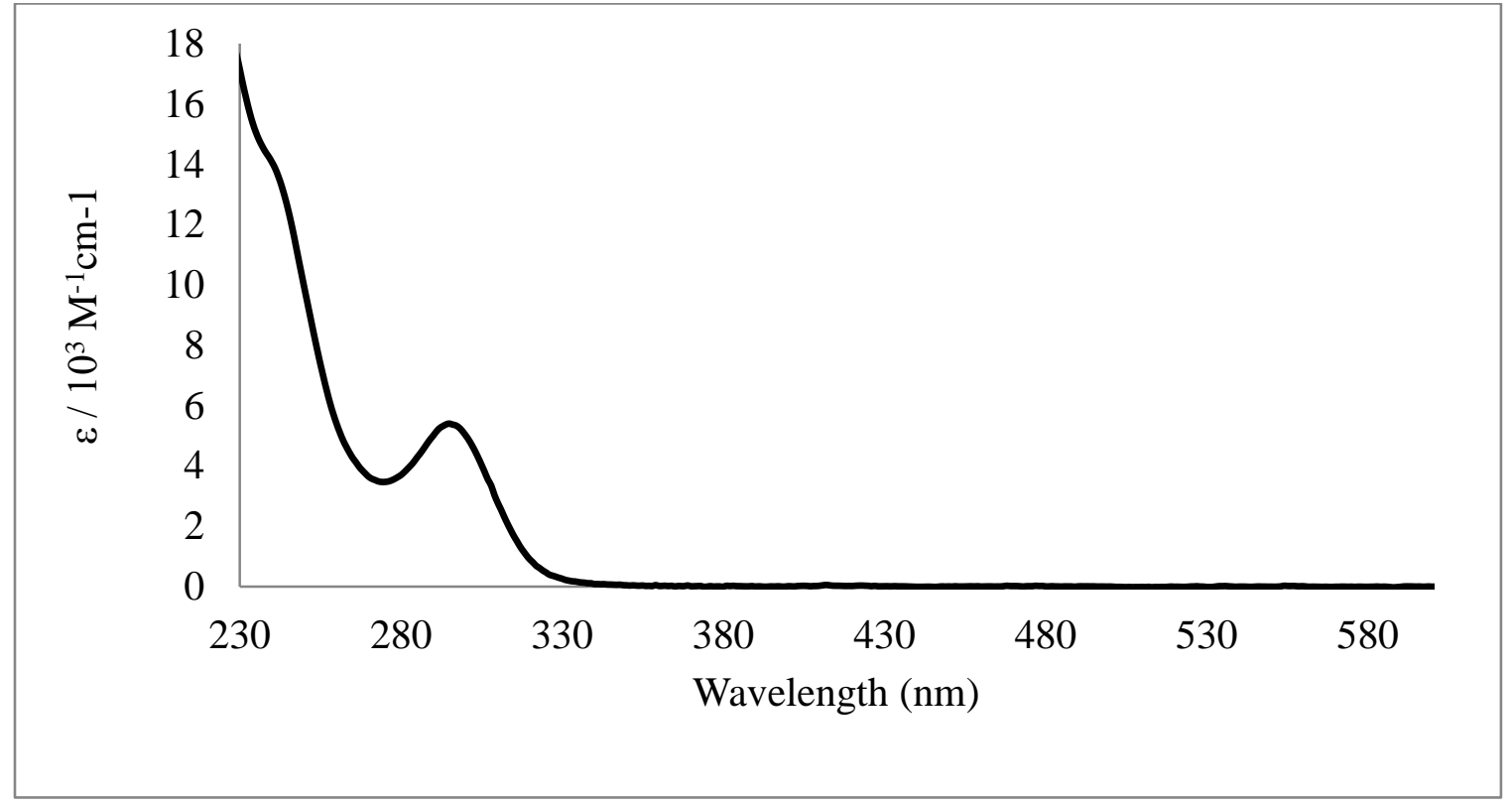

Figure 4.8.6. Electronic absorption spectrum of trans-Pt( $\left.\mathrm{PEt}_{3}\right)_{2}(\mathrm{Br})(2$-aminophenyl) $1(\mathrm{NPh})$ in $\mathrm{CH}_{2} \mathrm{Cl}_{2}$. 


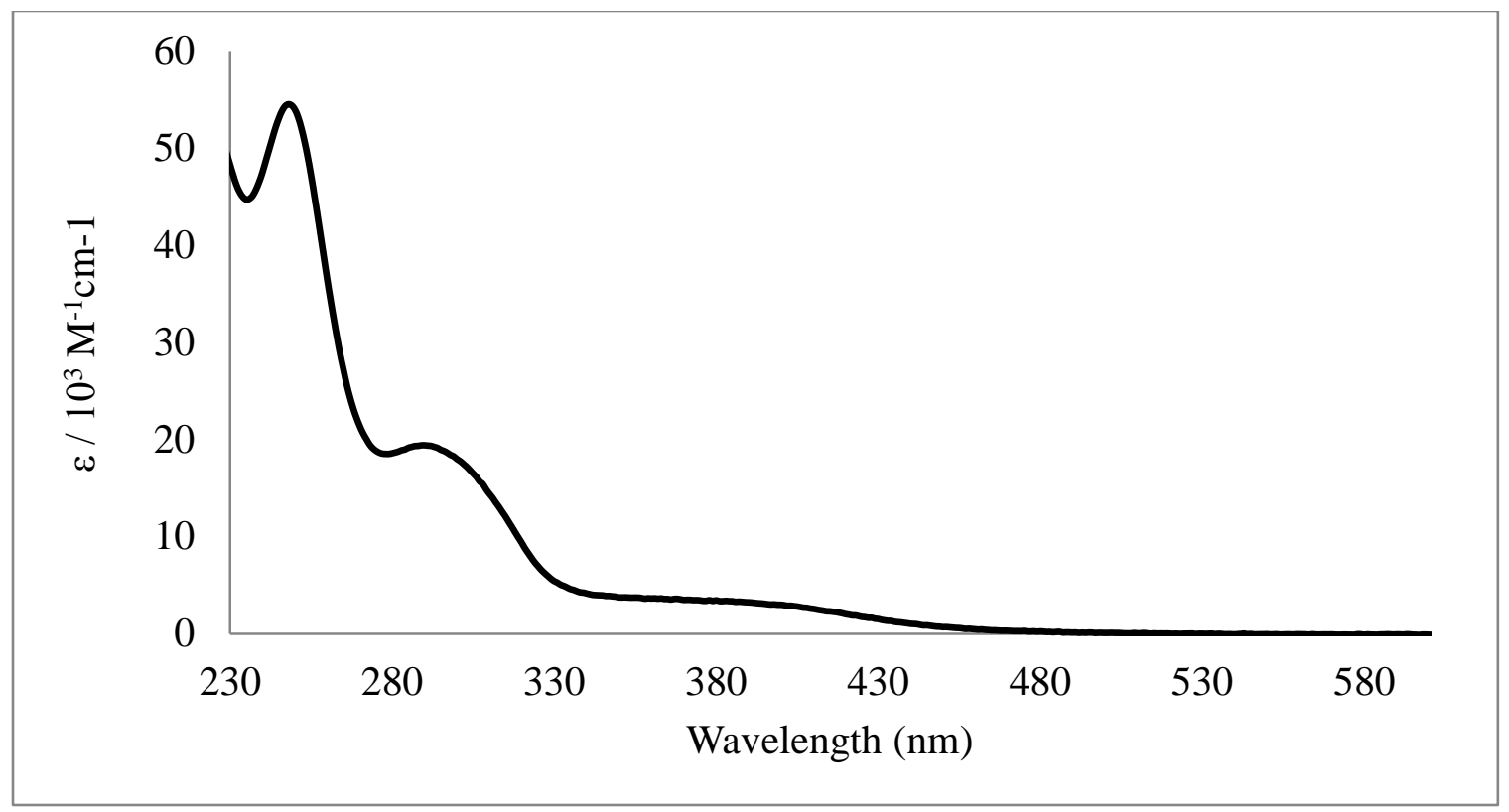

Figure 4.8.7. Electronic absorption spectrum of trans- $\mathrm{Pt}\left(\mathrm{PEt}_{3}\right)_{2}(\mathrm{Br})_{3}(3,5$-dibromo-2aminophenyl) $2(\mathrm{BrNPh})$ in $\mathrm{CH}_{2} \mathrm{Cl}_{2}$.

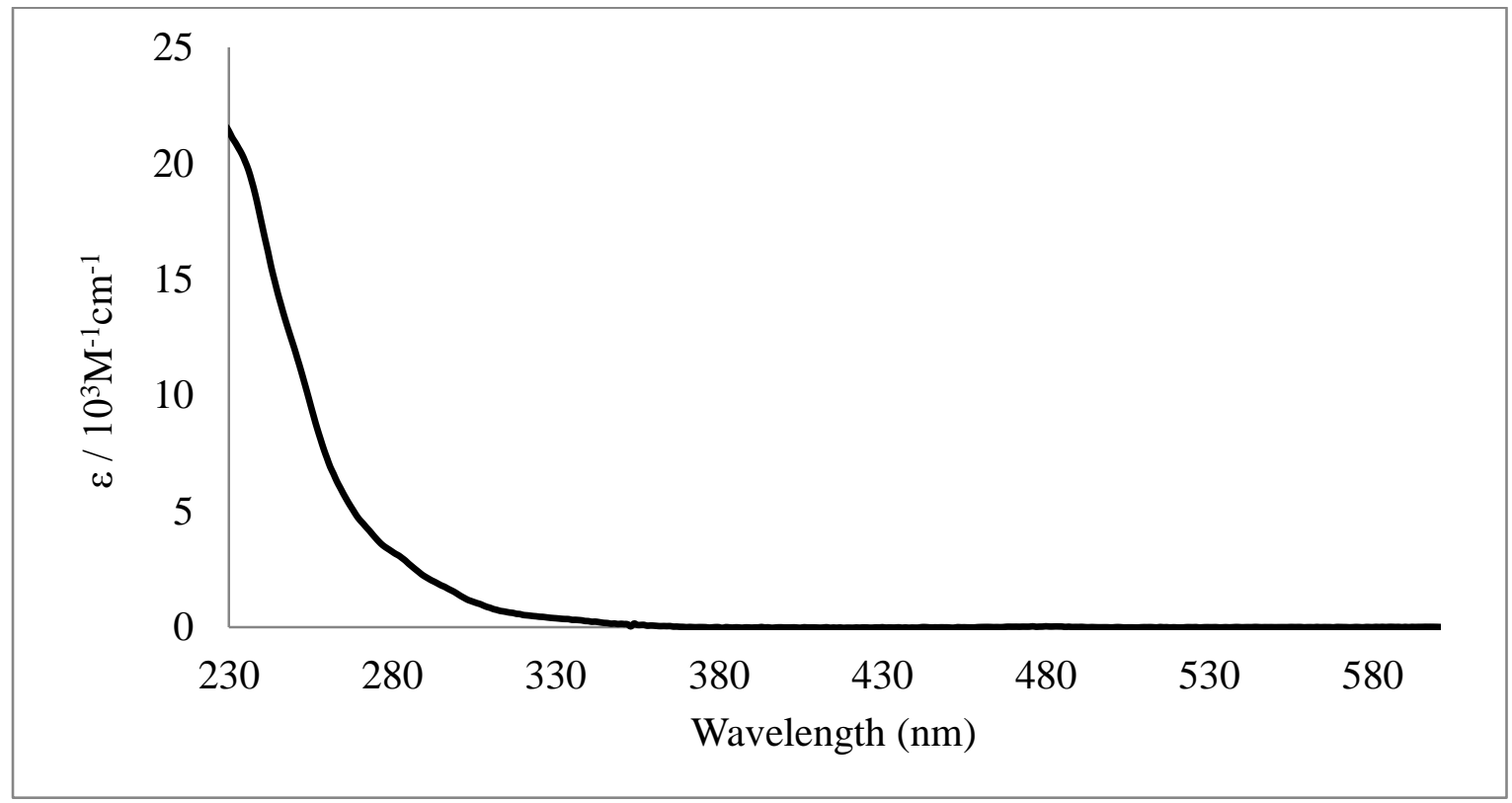

Figure 4.8.8. Electronic absorption spectrum of trans- $\mathrm{Pt}\left(\mathrm{PEt}_{3}\right)_{2}(\mathrm{Br}) \quad(2,6-$ dimethoxyphenyl) $\mathbf{1}\left(\mathrm{MeO}_{2} \mathrm{Ph}\right)$ in $\mathrm{CH}_{2} \mathrm{Cl}_{2}$. 


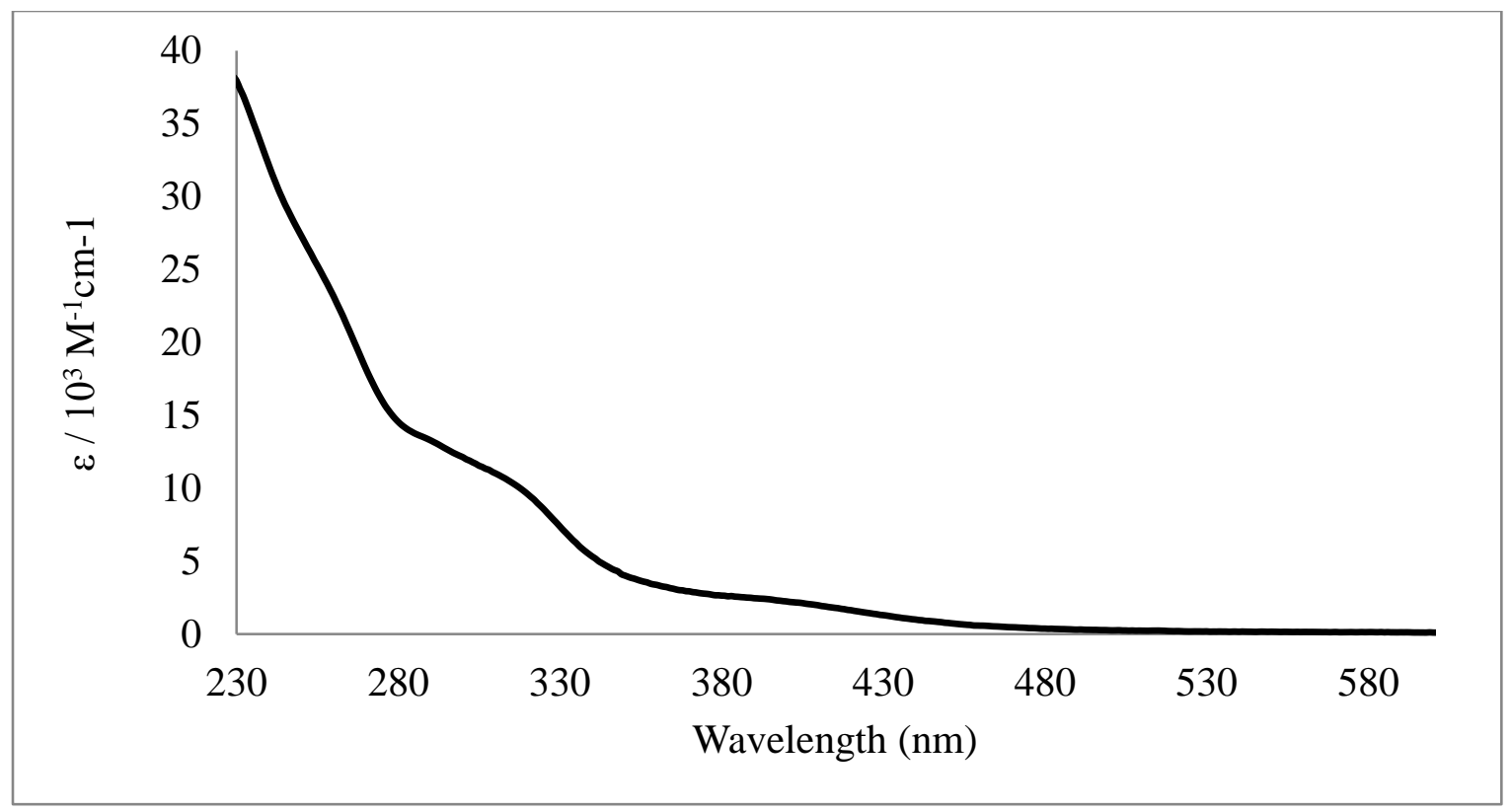

Figure 4.8.9. Electronic absorption spectrum of trans-Pt( $\left(\mathrm{PEt}_{3}\right)_{2}(\mathrm{Br})_{3}(3,5$-dibromo-2,6dimethoxyphenyl) 2( $\left.\mathrm{BrMeO}_{2} \mathrm{Ph}\right)$ in $\mathrm{CH}_{2} \mathrm{Cl}_{2}$.

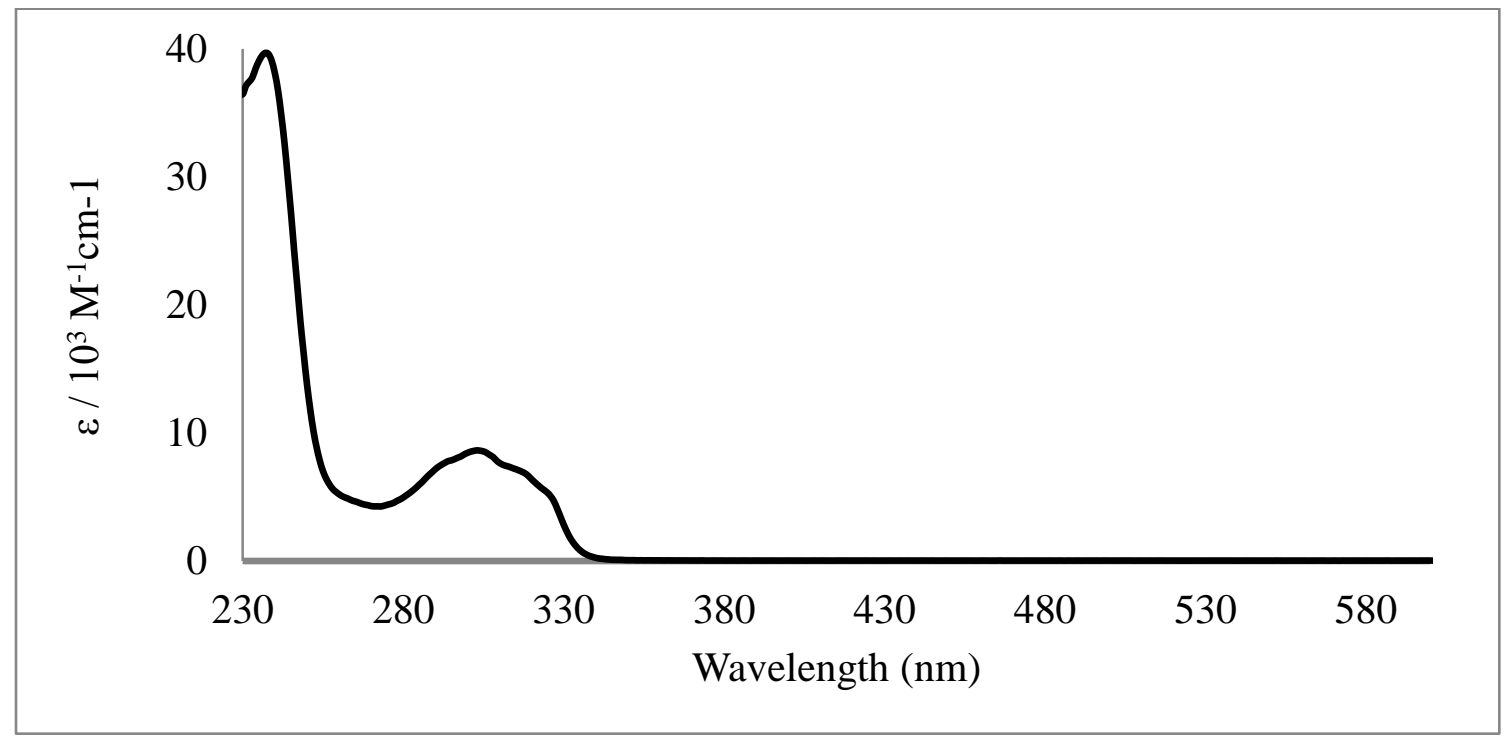

Figure 4.8.10. Electronic absorption spectrum of 1 (1-Nap) in $\mathrm{CH}_{2} \mathrm{Cl}_{2}$. 


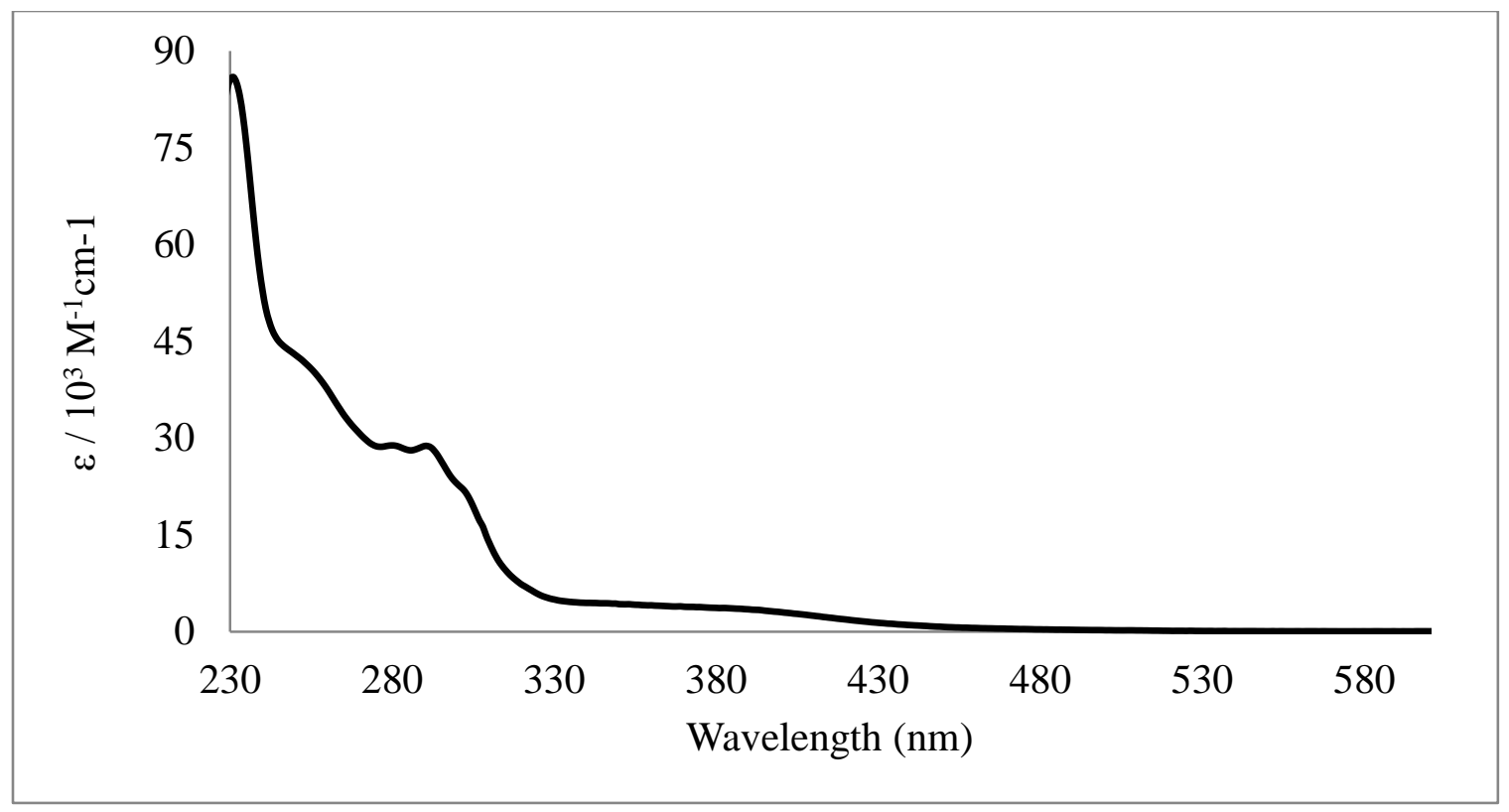

Figure 4.8.11. Electronic absorption spectrum of 2(1-Nap) in hexane.

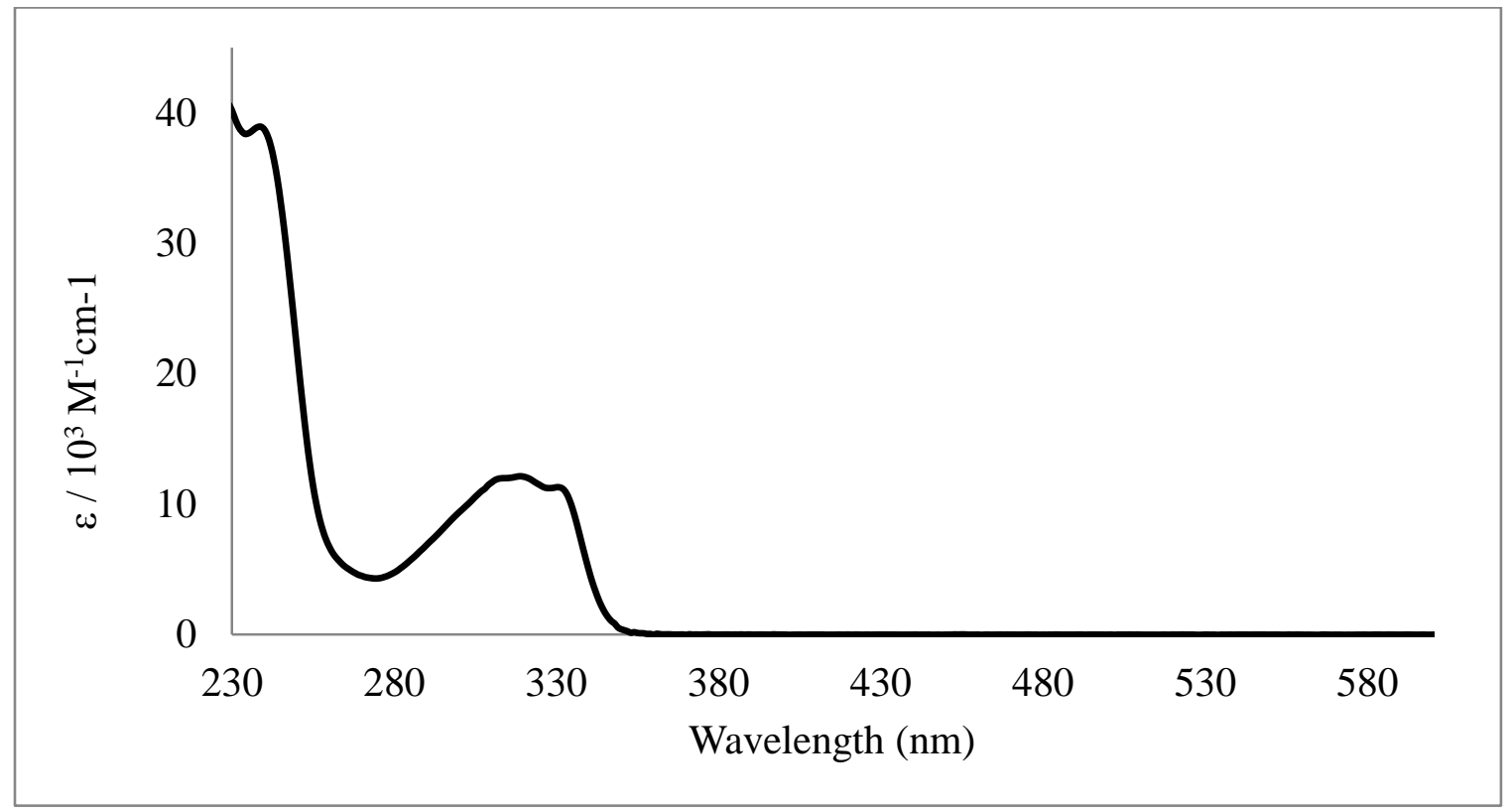

Figure 4.8.12. Electronic absorption spectrum of $\mathbf{1}$ (BrNap) in $\mathrm{CH}_{2} \mathrm{Cl}_{2}$. 


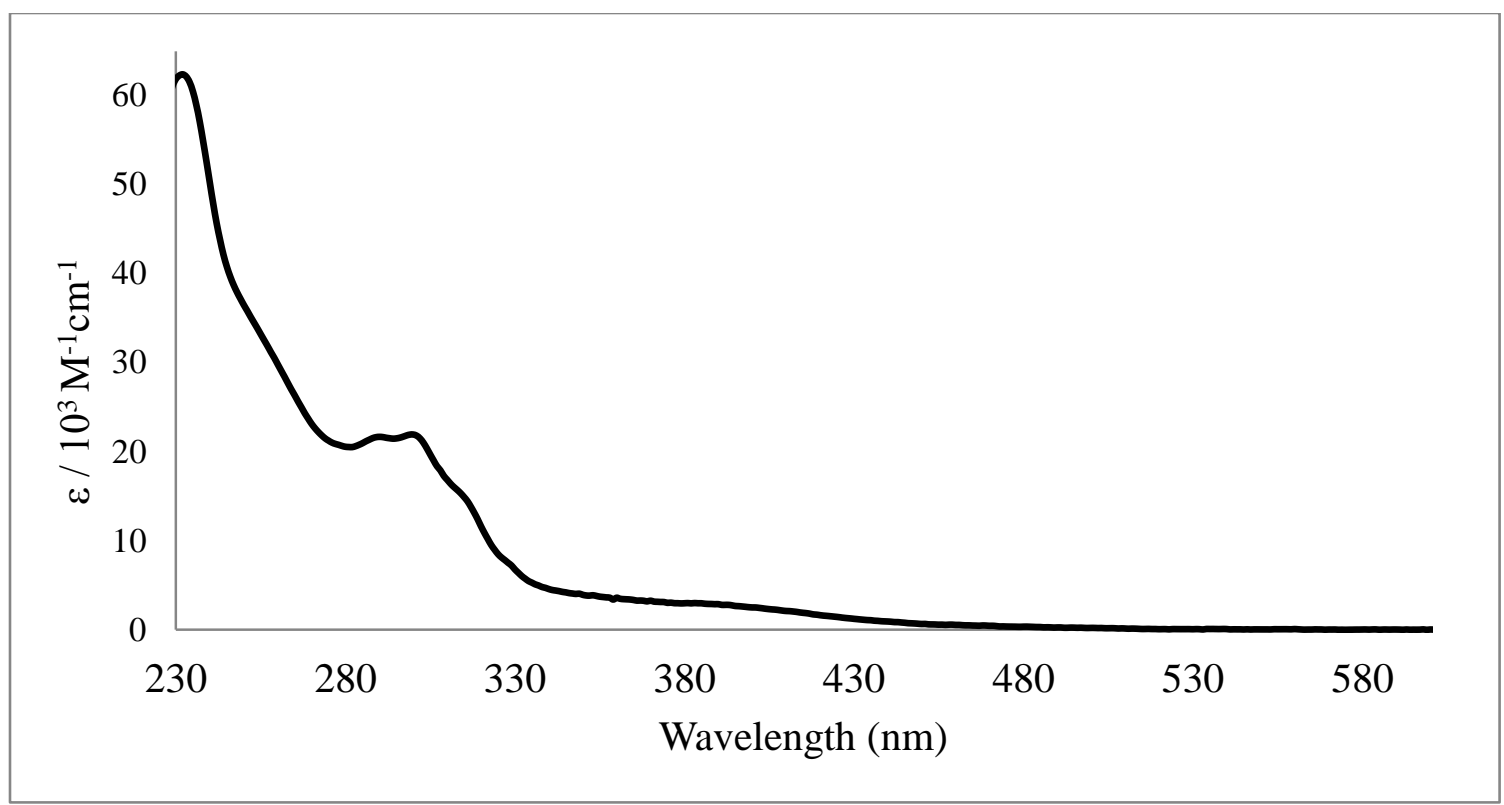

Figure 4.8.13. Electronic absorption spectrum of 2 (BrNap) in $\mathrm{CH}_{2} \mathrm{Cl}_{2}$.

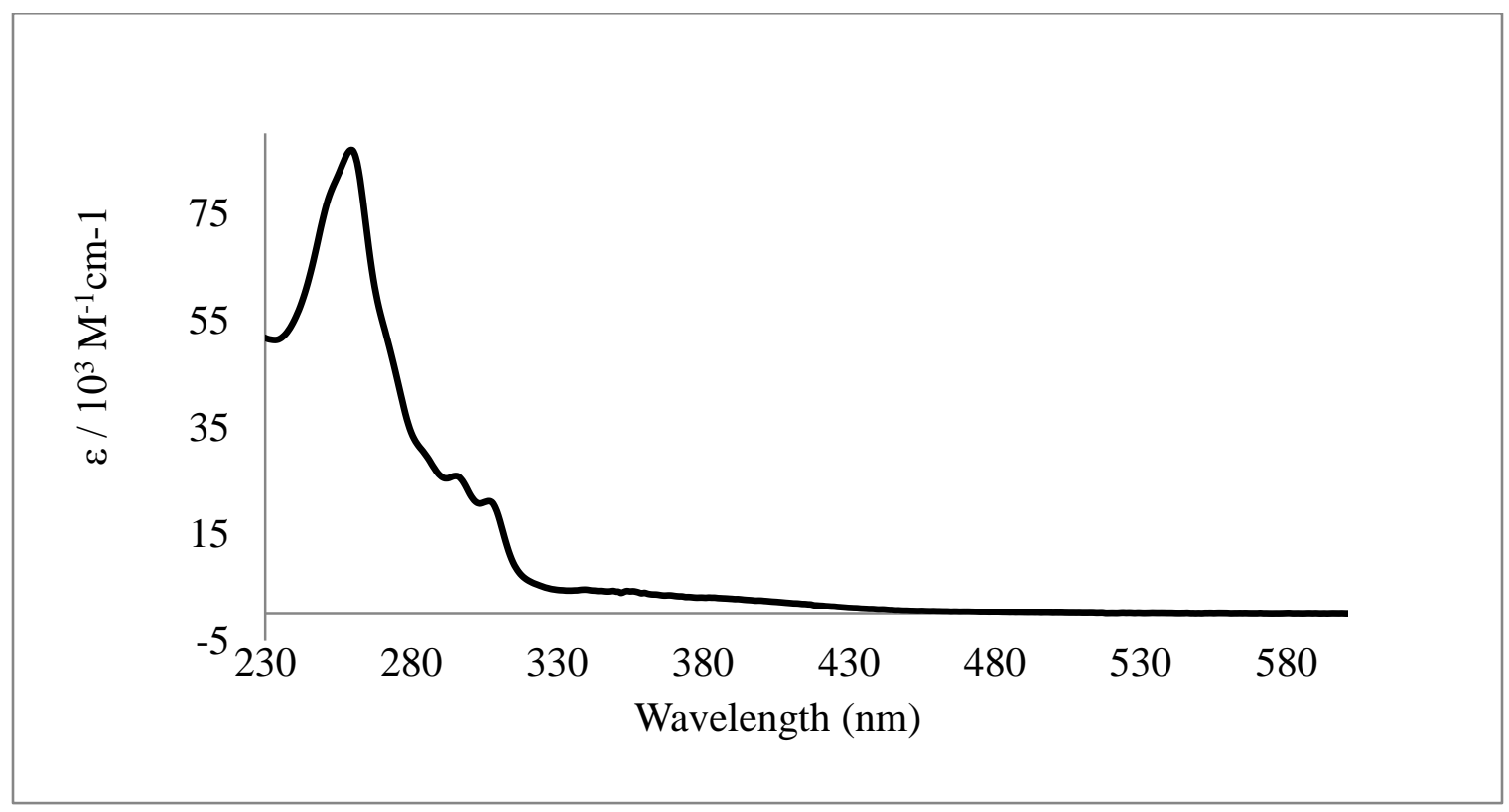

Figure 4.8.14. Electronic absorption spectrum of 2 (Phen) in $\mathrm{CH}_{2} \mathrm{Cl}_{2}$. 


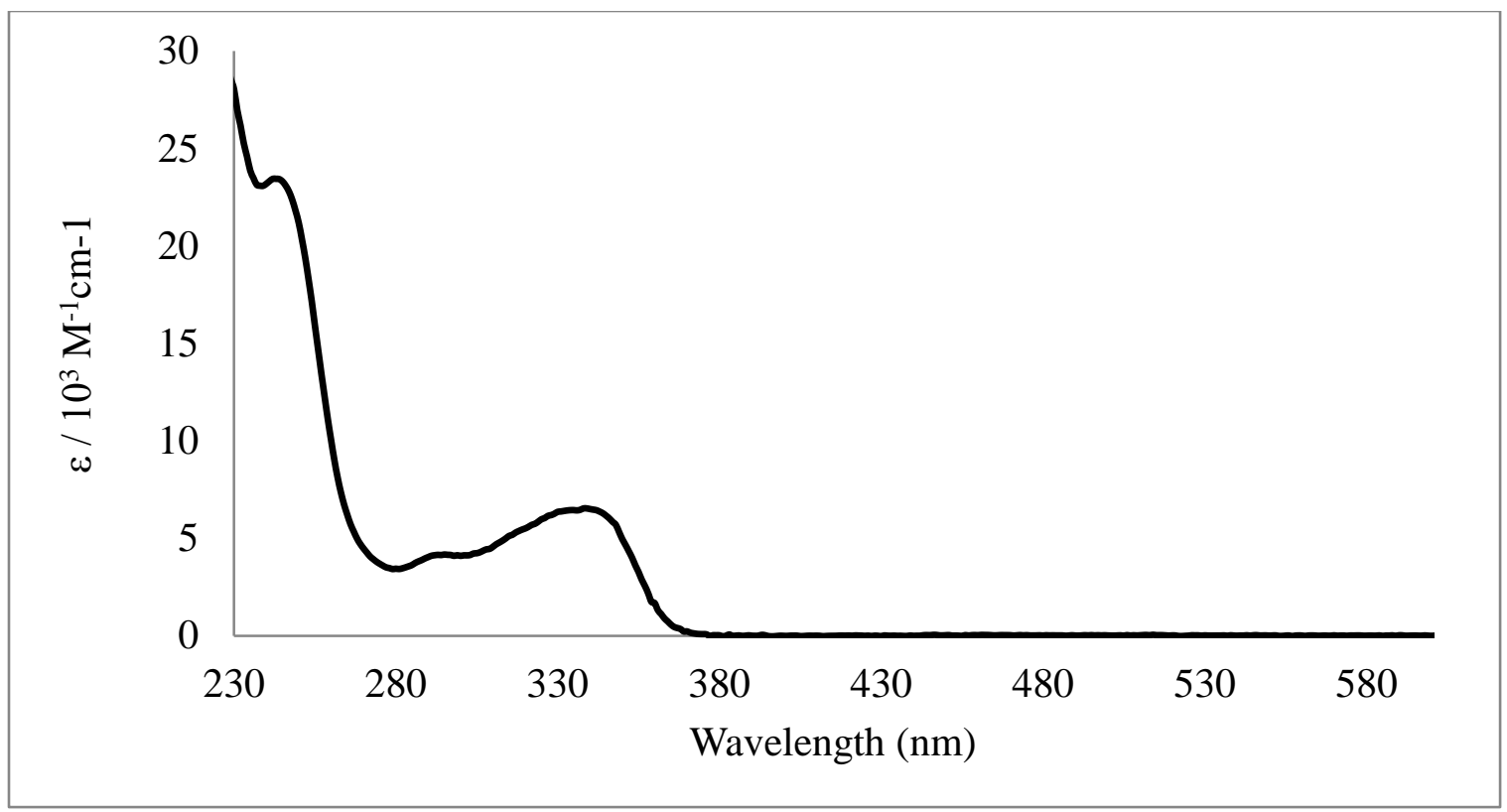

Figure 4.8.15. Electronic absorption spectrum of $\mathbf{1}(\mathrm{DiPt})$ in $\mathrm{CH}_{2} \mathrm{Cl}_{2}$.

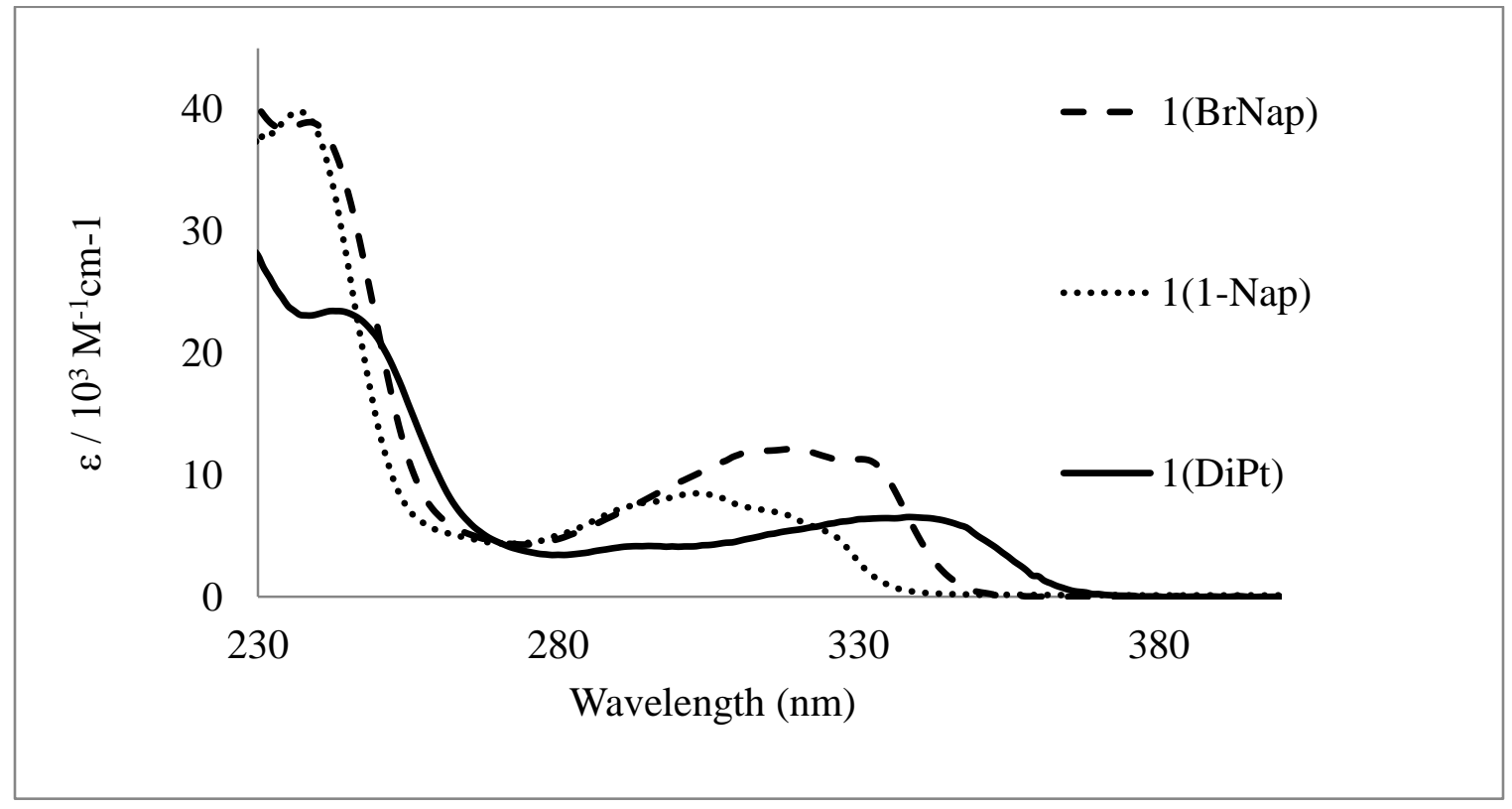

Figure 4.8.16. Electronic absorption spectra of $\mathbf{1}(\mathrm{BrNap}), \mathbf{1}(1-\mathrm{Nap})$ and $\mathbf{1}(\mathrm{DiPt})$ in $\mathrm{CH}_{2} \mathrm{Cl}_{2}$. 


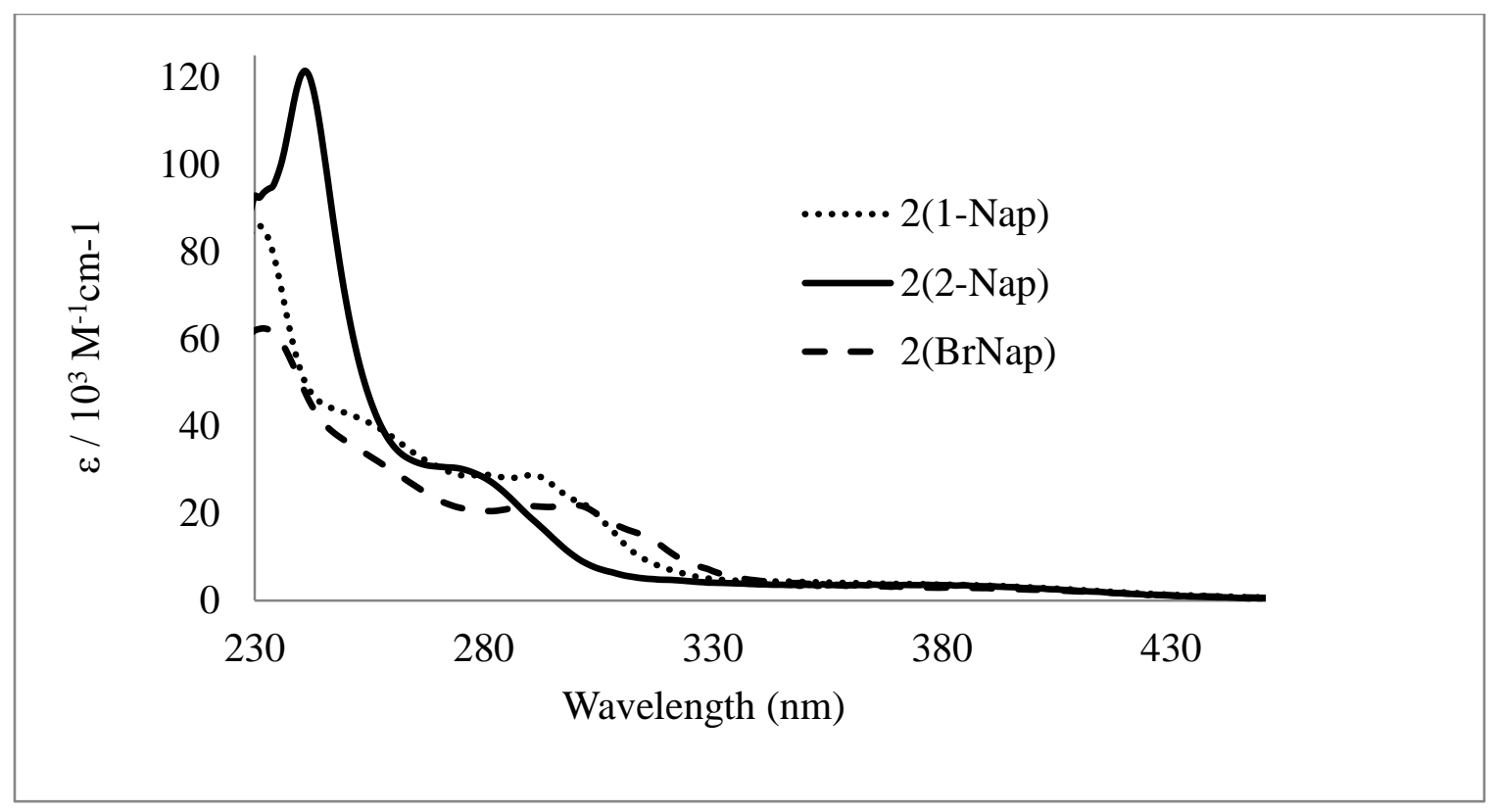

Figure 4.8.17. Electronic absorption spectra of 2(1-Nap), 2(2-Nap) and 2(BrNap) in $\mathrm{CH}_{2} \mathrm{Cl}_{2}$.

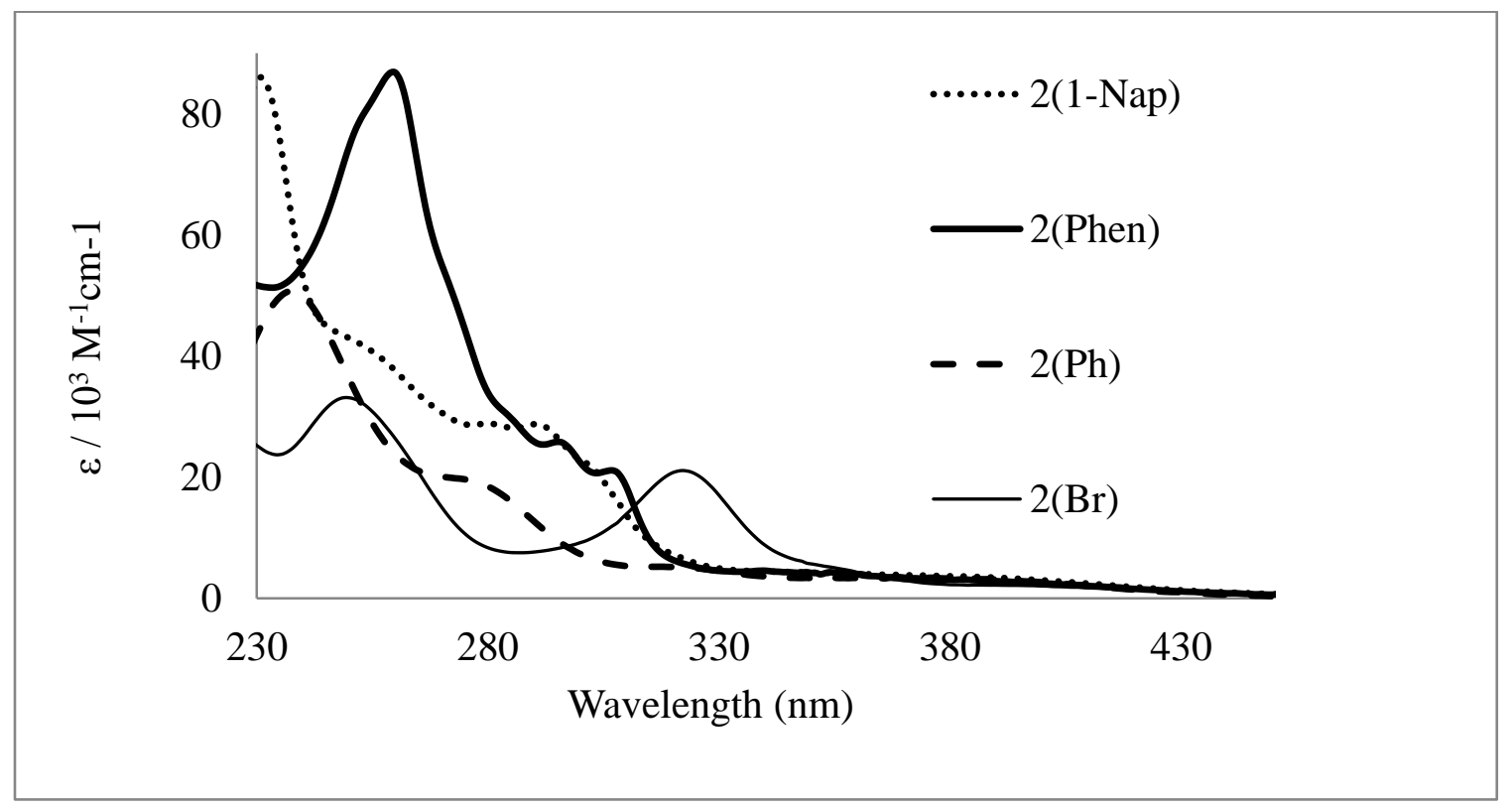

Figure 4.8.18. Electronic absorption spectra of 2(1-Nap), 2(Phen), 2(Ph) and $2(\mathrm{Br})$ in $\mathrm{CH}_{2} \mathrm{Cl}_{2}$. 


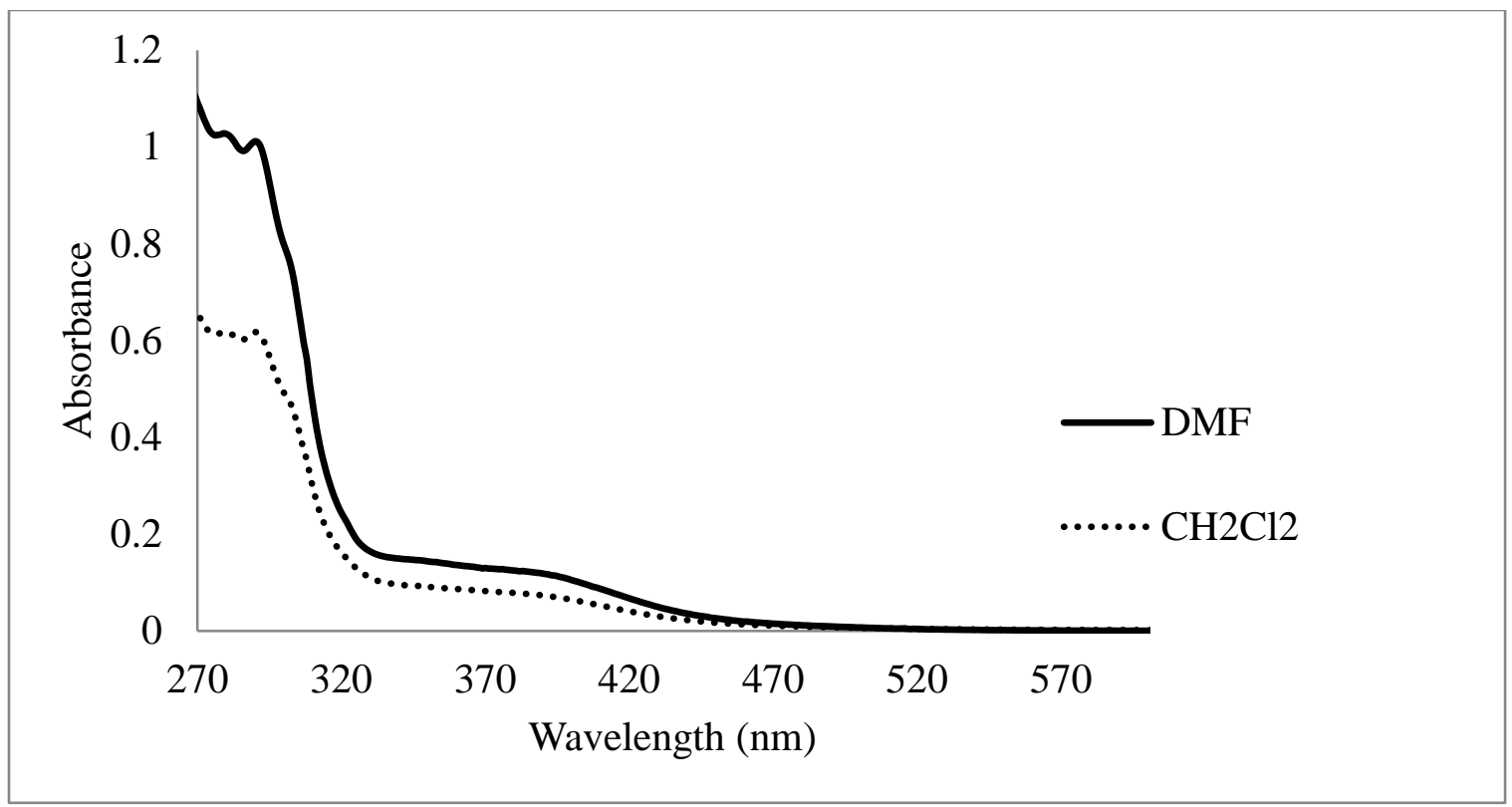

Figure 4.8.19. Electronic absorption spectra of 2(1-Nap) in DMF and $\mathrm{CH}_{2} \mathrm{Cl}_{2}$.

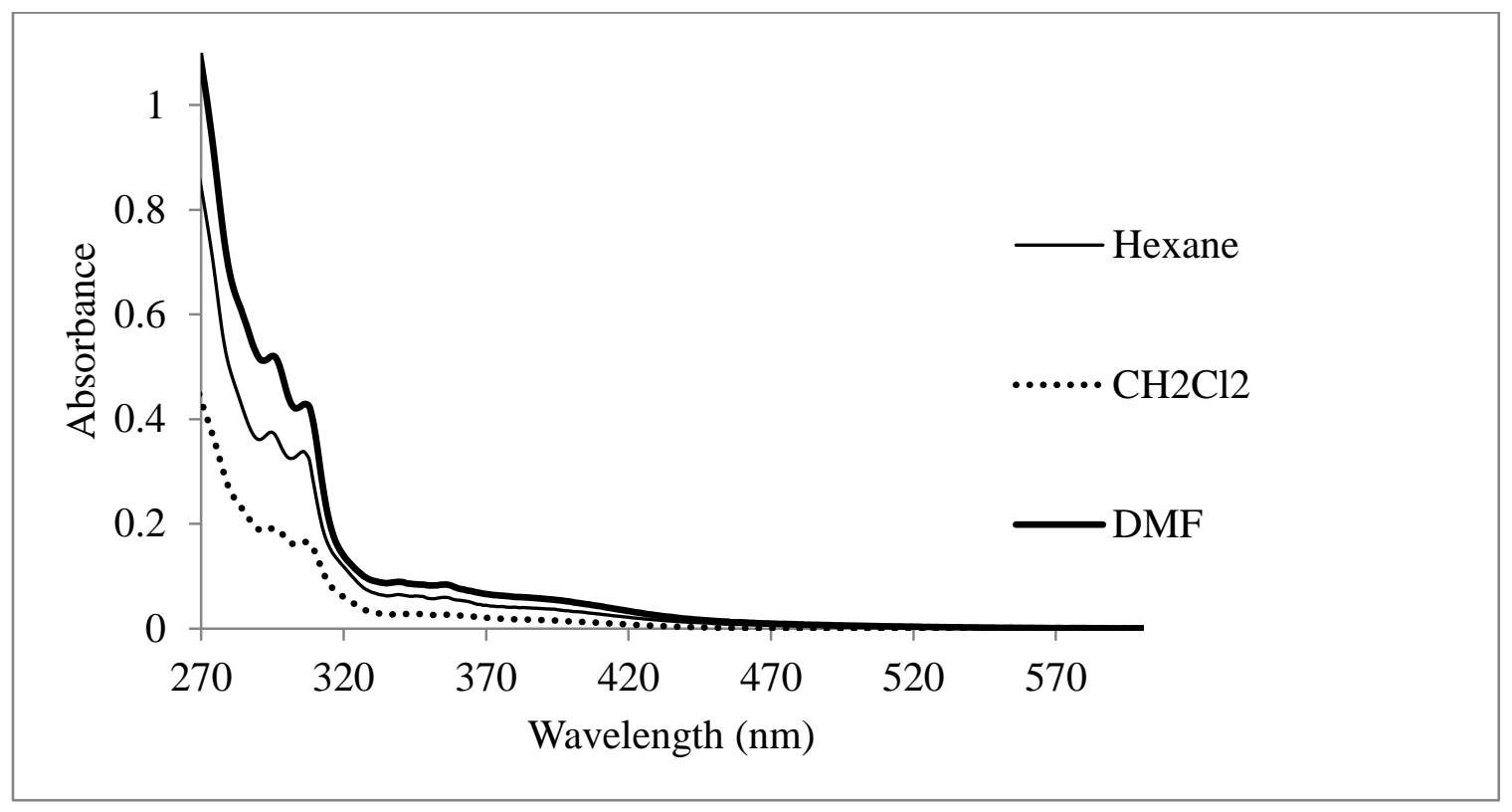

Figure 4.8.20. Electronic absorption spectra of 2(Phen) in hexane, $\mathrm{CH}_{2} \mathrm{Cl}_{2}$ and $\mathrm{DMF}$. 


\subsection{Crystal Structures}

Crystal Structure Determinations. These were mostly done by Dr. Charles Barnes. Few structures were determined by Dr. Morgan A Moody. Crystals were mounted by transferring the crystals from the crystallization vessel into a pool of heavy oil. A suitable crystal was selected and removed from the oil with a glass fiber. With the oil covered crystal adhering to the end of the glass fiber the sample was transferred to an $\mathrm{N}_{2}$ cold stream on the diffractometer and data were collected at $100{ }^{0} \mathrm{C}$. Data reduction and processing followed routine procedures. Prof. Sharp also carried out these procedures on few structures. Analytical absorption corrections were applied and provided adequate corrections. Structures were solved by direct methods. Details may be found in the CIF file $^{30}$ and in Tables 5.9.1-5.9.4. 


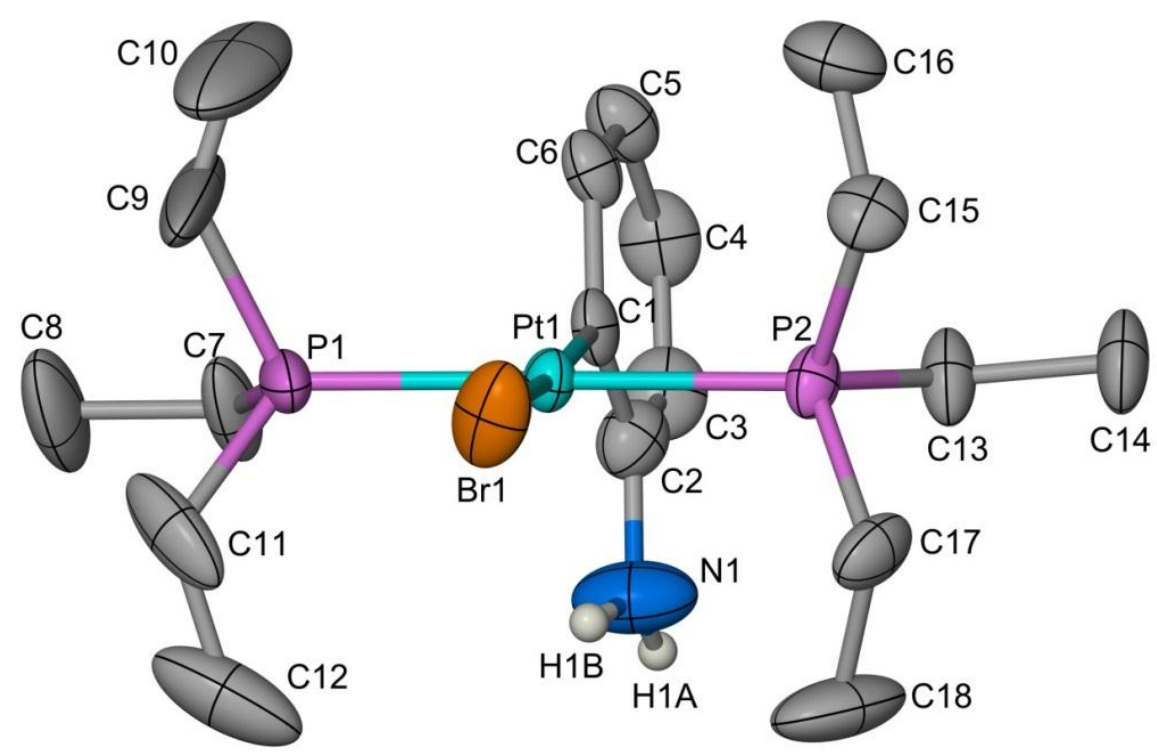

Figure 4.9.1. XSeed/POV-Ray drawing of $\mathbf{1}(\mathrm{NPh})$. Carbon bonded hydrogen atoms omitted. Atoms are drawn as 50\% probability ellipsoids. H1A and H1B were refined isotropically. ${ }^{30}$ 


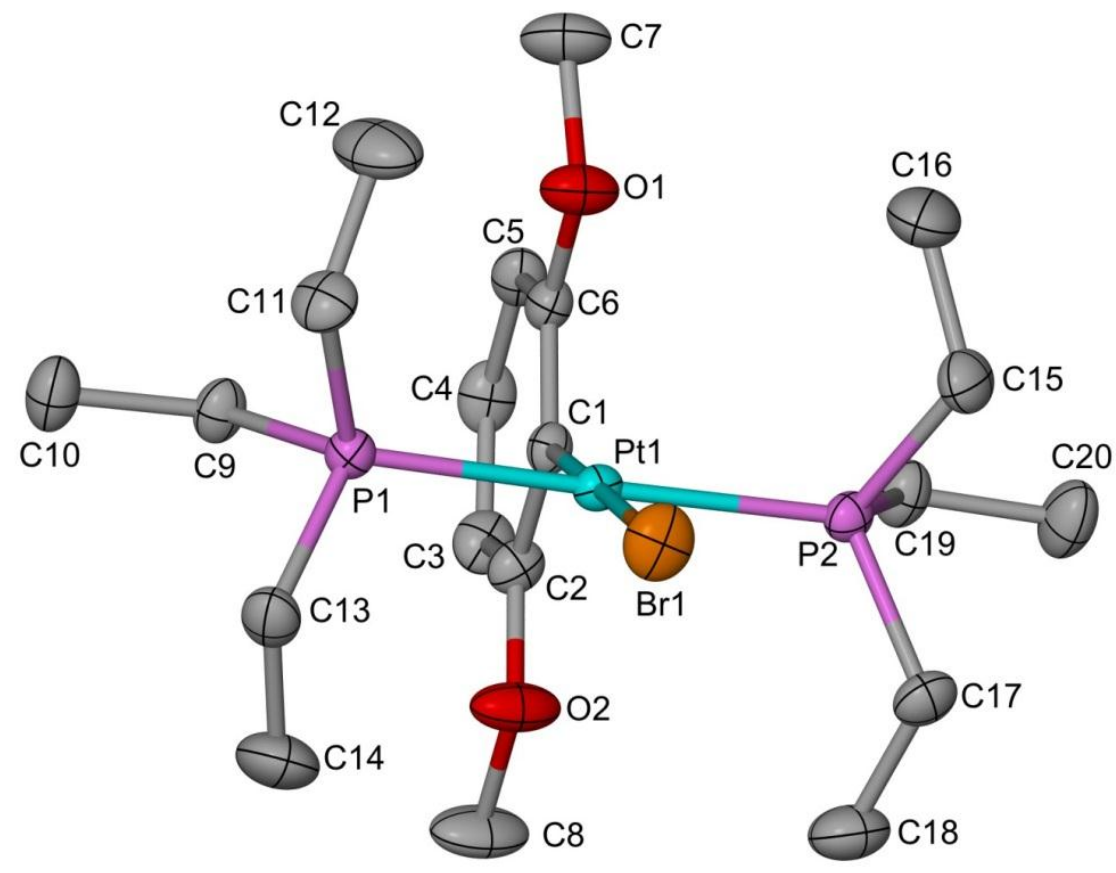

Figure 4.9.2. $\mathrm{XSeed} / \mathrm{POV}$-Ray drawing of $\mathbf{1}\left(\mathrm{BrMeO}_{2} \mathrm{Ph}\right)$. Hydrogen atoms omitted. Atoms are drawn as $50 \%$ probability ellipsoids. ${ }^{30}$ 


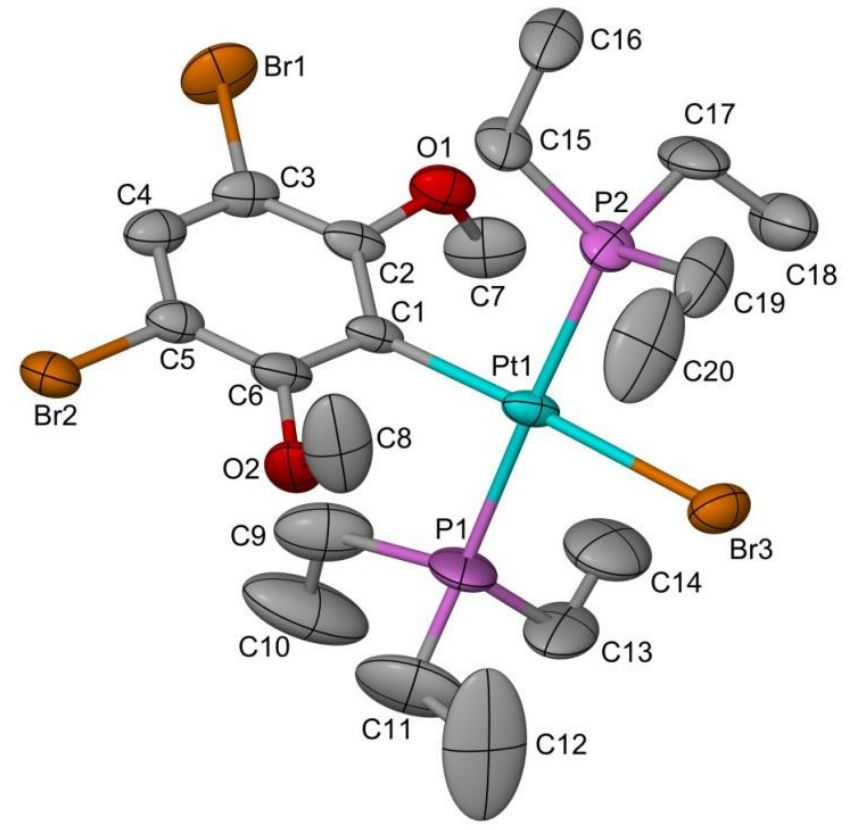

Figure 4.9.3. XSeed/POV-Ray drawing of $1\left(\mathrm{BrMeO}_{2} \mathrm{Ph}\right)$. Hydrogen atoms omitted. Atoms are drawn as $50 \%$ probability ellipsoids. ${ }^{30}$ 


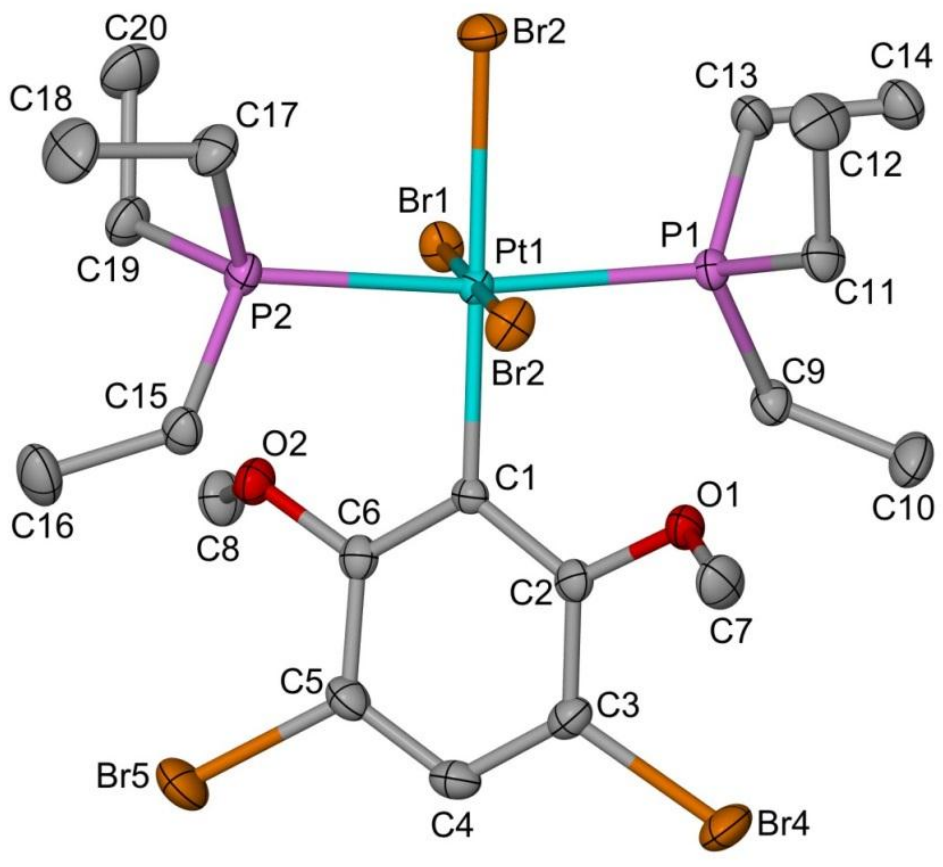

Figure 4.9.4. XSeed/POV-Ray drawing of $2\left(\mathrm{BrMeO}_{2} \mathrm{Ph}\right)$. Hydrogen atoms omitted. Atoms are drawn as $50 \%$ probability ellipsoids. ${ }^{30}$ 


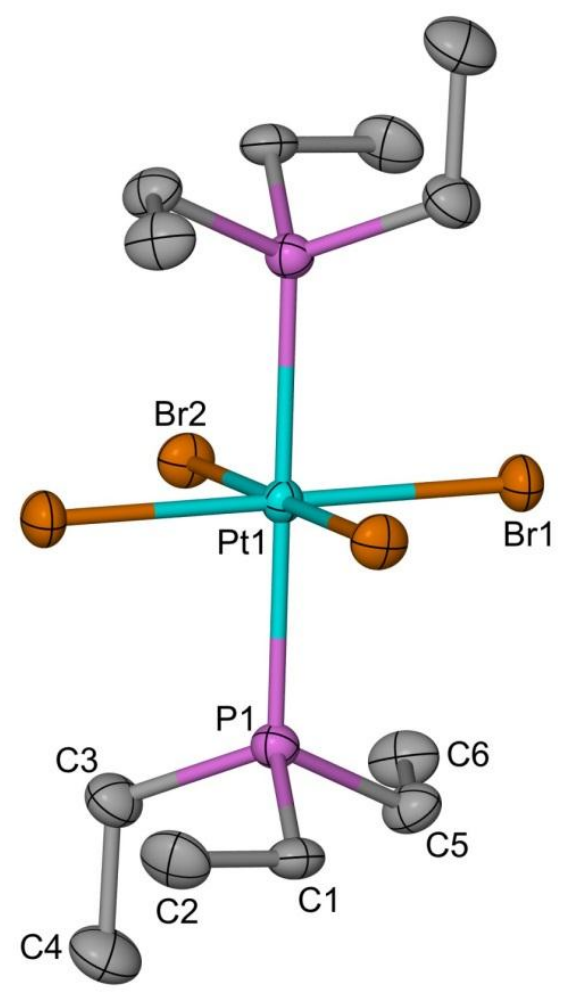

Figure 4.9.5. XSeed/POV-Ray drawing of 2(Br). Hydrogen atoms omitted. Atoms are drawn as $50 \%$ probability ellipsoids. Named and unnamed atoms are inversion related. $^{30}$ 


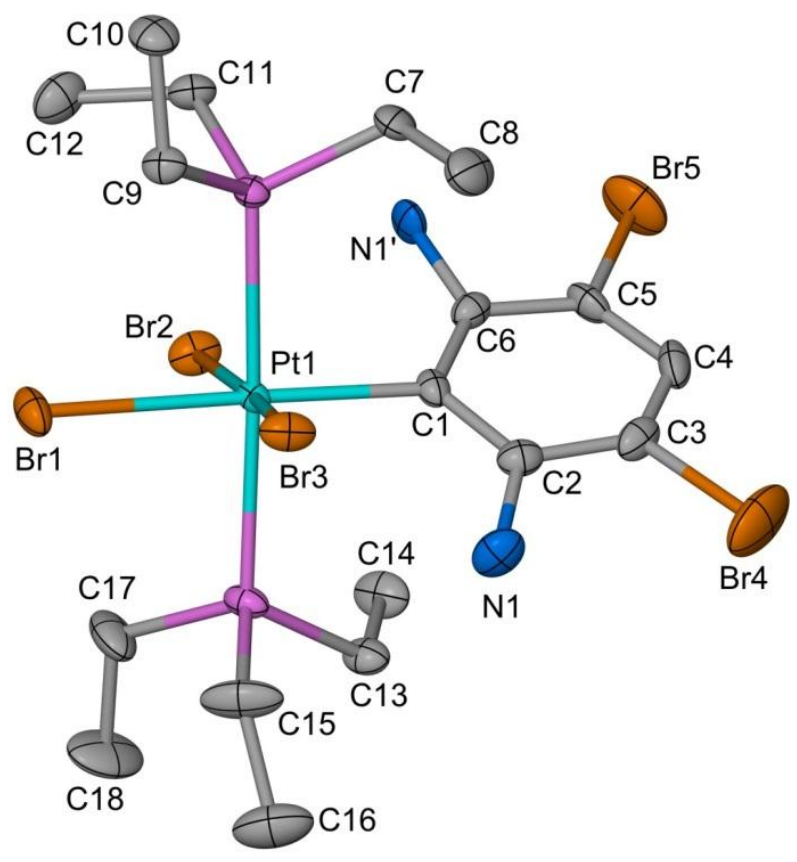

Figure 4.9.6. XSeed/POV-Ray drawing of 2(BrNPh). Hydrogen atoms omitted. Atoms are drawn as $50 \%$ probability ellipsoids. $\mathrm{N} 1$ and $\mathrm{N} 1$ ' are disordered positions of the $\mathrm{NH}_{2}$ group and were refined to occupancies of $77 \%$ and $23 \%$, respectively. ${ }^{30}$ 


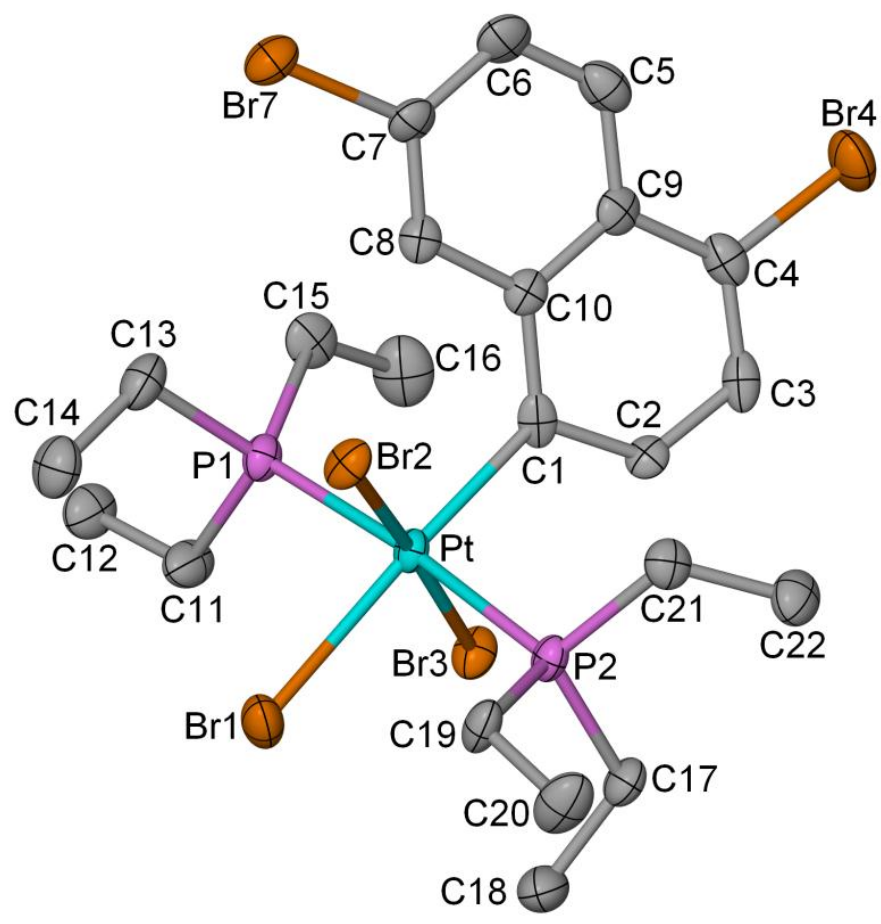

Figure 4.9.7. XSeed/POV-Ray drawing of 2(BrNapBr). Hydrogen atoms omitted. Atoms are drawn as $50 \%$ probability ellipsoids. There is crystallographic disorder at C6. 
Table 4.9.1. Crystal data and structure refinement for di-trans-Pt(PEt3)2(Br)3(6,7-dibromo1,4-naphthyl) 2(DiBrPt).

Identification code

Empirical formula

Formula weight

Temperature

Wavelength

Crystal system

Space group

Unit cell dimensions

Volume

Z

Density (calculated)

Absorption coefficient

$\mathrm{F}(000)$

Crystal size

Theta range for data collection

Index ranges

Reflections collected

Independent reflections

Completeness to theta $=27.53^{\circ}$

Absorption correction

Max. and min. transmission

Refinement method

Data / restraints / parameters

Goodness-of-fit on $\mathrm{F}^{2}$

Final $\mathrm{R}$ indices [I>2sigma(I)]

$\mathrm{R}$ indices (all data)

Largest diff. peak and hole
2(DiBrPt)

$\mathrm{C}_{46} \mathrm{H}_{76} \mathrm{Br}_{8} \mathrm{P}_{4} \mathrm{Pt}_{2}$

1782.41

173(2) K

$0.71073 \AA$

Triclinic

P -1

$\mathrm{a}=13.5673(19) \AA \quad \alpha=101.664(2)^{\circ}$.

$\mathrm{b}=14.476(2) \AA \quad \beta=90.484(2)^{\circ}$.

$\mathrm{c}=16.057(2) \AA$

$\gamma=110.6440(10)^{\circ}$.

2879.2(7) $\AA^{3}$

2

$2.056 \mathrm{Mg} / \mathrm{m}^{3}$

$10.546 \mathrm{~mm}^{-1}$

1696

$0.40 \times 0.35 \times 0.15 \mathrm{~mm}^{3}$

1.61 to $27.53^{\circ}$.

$-17<=\mathrm{h}<=17,-18<=\mathrm{k}<=18,-20<=\mathrm{l}<=20$

34034

$13057[\mathrm{R}(\mathrm{int})=0.0351]$

$98.5 \%$

Semi-empirical from equivalents

0.30 and 0.12

Full-matrix least-squares on $\mathrm{F}^{2}$

13057 / 0 / 553

1.015

$\mathrm{R} 1=0.0235, \mathrm{wR} 2=0.0528$

$\mathrm{R} 1=0.0305, \mathrm{wR} 2=0.0550$

0.999 and -1.360 e. $\AA^{-3}$ 
Table 4.9.2. Crystal data and structure refinement for $\mathrm{Pt}($ depe $)(\mathrm{Br}) 4$ 2(depe).

Identification code
Empirical formula
Formula weight
Temperature
Wavelength
Crystal system
Space group
Unit cell dimensions

Volume

$\mathrm{Z}$

Density (calculated)

Absorption coefficient

$\mathrm{F}(000)$

Crystal size

Theta range for data collection

Index ranges

Reflections collected

Independent reflections

Completeness to theta $=27.54^{\circ}$

Absorption correction

Max. and min. transmission

Refinement method

Data / restraints / parameters

Goodness-of-fit on $\mathrm{F}^{2}$

Final R indices [I $>2 \operatorname{sigma}(\mathrm{I})]$

$\mathrm{R}$ indices (all data)

Largest diff. peak and hole

\author{
2(depe) \\ $\mathrm{C}_{10} \mathrm{H}_{24} \mathrm{Br}_{4} \mathrm{P}_{2} \mathrm{Pt}$ \\ 720.96 \\ 100(1) K \\ $0.71073 \AA$
}

Monoclinic

C $2 / \mathrm{c}$

$$
\begin{array}{ll}
\mathrm{a}=9.3145(11) \AA & \alpha=90^{\circ} . \\
\mathrm{b}=11.9794(14) \AA & \beta=105.0420(10)^{\circ} . \\
\mathrm{c}=17.361(2) \AA & \gamma=90^{\circ} .
\end{array}
$$

$1870.8(4) \AA^{3}$

4

$2.560 \mathrm{Mg} / \mathrm{m}^{3}$

$16.197 \mathrm{~mm}^{-1}$

1328

$0.30 \times 0.15 \times 0.10 \mathrm{~mm}^{3}$

2.43 to $27.54^{\circ}$.

$-12<=\mathrm{h}<=12,-15<=\mathrm{k}<=15,-22<=\mathrm{l}<=22$

10651

$2145[\mathrm{R}(\mathrm{int})=0.0265]$

$99.4 \%$

Semi-empirical from equivalents

0.29 and 0.10

Full-matrix least-squares on $\mathrm{F}^{2}$

$2145 / 0 / 80$

1.120

$\mathrm{R} 1=0.0173, \mathrm{wR} 2=0.0410$

$\mathrm{R} 1=0.0196, \mathrm{wR} 2=0.0417$

1.117 and -0.932 e. $\AA^{-3}$ 
Table 4.9.3. Crystal data and structure refinement for trans- $\mathrm{Pt}\left(\mathrm{PEt}_{3}\right)_{2}(\mathrm{Br})_{3}(5$-bromo-2isopropoxyphenyl) 2(BriPrOPh).

Identification code

Empirical formula

Formula weight

Temperature

Wavelength

Crystal system

Space group

Unit cell dimensions

Volume

$\mathrm{Z}$

Density (calculated)

Absorption coefficient

$\mathrm{F}(000)$

Crystal size

Theta range for data collection

Index ranges

Reflections collected

Independent reflections

Completeness to theta $=27.62^{\circ}$

Absorption correction

Max. and min. transmission

Refinement method

Data / restraints / parameters

Goodness-of-fit on $\mathrm{F}^{2}$

Final R indices [I $>2 \operatorname{sigma}(\mathrm{I})]$

$\mathrm{R}$ indices (all data)

Largest diff. peak and hole
2(BriPrOPh)

$\mathrm{C}_{21} \mathrm{H}_{40} \mathrm{Br}_{4} \mathrm{O} \mathrm{P}_{2} \mathrm{Pt}$

885.20

173(2) K

$0.71073 \AA$

Monoclinic

P 21/n

$\mathrm{a}=12.761(3) \AA$

$\alpha=90^{\circ}$.

$\mathrm{b}=13.456(3) \AA$

$\beta=102.127(2)^{\circ}$.

$\mathrm{c}=17.406(3) \AA$

$\gamma=90^{\circ}$.

2922.3(10) $\AA^{3}$

4

$2.012 \mathrm{Mg} / \mathrm{m}^{3}$

$10.392 \mathrm{~mm}^{-1}$

1688

$0.45 \times 0.35 \times 0.15 \mathrm{~mm}^{3}$

1.81 to $27.62^{\circ}$.

$-16<=\mathrm{h}<=16,-17<=\mathrm{k}<=17,-22<=1<=22$

32793

$6725[\mathrm{R}(\mathrm{int})=0.0635]$

$98.8 \%$

Semi-empirical from equivalents

0.30 and 0.12

Full-matrix least-squares on $\mathrm{F}^{2}$

6725 / 2 / 300

1.017

$\mathrm{R} 1=0.0365, \mathrm{wR} 2=0.0673$

$\mathrm{R} 1=0.0728, \mathrm{wR} 2=0.0799$

1.372 and -1.642 e. $\AA^{-3}$ 
Table 4.9.4. Crystal data and structure refinement for di-trans-Pt(PEt3)2(Br)(1,4-naphthyl) 1(DiPt).

\author{
Identification code \\ Empirical formula \\ Formula weight \\ Temperature \\ Wavelength \\ Crystal system \\ Space group \\ Unit cell dimensions
}

Volume

Z

Density (calculated)

Absorption coefficient

$\mathrm{F}(000)$

Crystal size

Theta range for data collection

Index ranges

Reflections collected

Independent reflections

Completeness to theta $=27.59^{\circ}$

Absorption correction

Max. and min. transmission

Refinement method

Data / restraints / parameters

Goodness-of-fit on $\mathrm{F}^{2}$

Final $\mathrm{R}$ indices [I>2sigma(I)]

$\mathrm{R}$ indices (all data)

Largest diff. peak and hole
1(DiPt)

$\mathrm{C}_{34} \mathrm{H}_{66} \mathrm{Br}_{2} \mathrm{P}_{4} \mathrm{Pt}_{2}$

1148.75

173(2) K

$0.71073 \AA$

Monoclinic

P 21/c

$\begin{array}{ll}\mathrm{a}=23.456(4) \AA & \alpha=90^{\circ} . \\ \mathrm{b}=12.643(2) \AA & \beta=99.486(2)^{\circ} . \\ \mathrm{c}=14.518(3) \AA & \gamma=90^{\circ} .\end{array}$

4246.6(13) $\AA^{3}$

4

$1.797 \mathrm{Mg} / \mathrm{m}^{3}$

$8.635 \mathrm{~mm}^{-1}$

2224

$0.30 \times 0.20 \times 0.05 \mathrm{~mm}^{3}$

1.76 to $27.59^{\circ}$.

$-30<=\mathrm{h}<=30,-16<=\mathrm{k}<=16,-18<=\mathrm{l}<=18$

48984

$9789[\mathrm{R}($ int $)=0.0376]$

$99.5 \%$

Semi-empirical from equivalents

0.67 and 0.38

Full-matrix least-squares on $\mathrm{F}^{2}$

9789 / 0 / 391

1.017

$\mathrm{R} 1=0.0237, \mathrm{wR} 2=0.0553$

$\mathrm{R} 1=0.0300, \mathrm{wR} 2=0.0580$

3.160 and -1.443 e. $\AA^{-3}$ 


\section{CONCLUSION AND OUTLOOK}

Overall, facile solution $\mathrm{Br}_{2}$ photoelimination from platinum(IV) complexes is observed in the presence of a trap. Endergonic and endothermic processes with free energy variation from 2 to $22 \mathrm{kcal} / \mathrm{mol}$ are observed. Less reactive traps (1-hexene and cis-2-hexene) yield a $\mathrm{Br}_{2}$ anti-addition product, indicating photolytic molecular bromine elimination. The mixed alkene bromination competition experiment with trans-3-hexene and 1-hexene support elimination of molecular bromine $\left(\mathrm{Br}_{2}\right)$, Photokinetic measurements in the presence of platinum(II) show a decreased rate supporting evolution of $\mathrm{Br}_{2}$ as well. Product profiles with a highly reactive trap such as TME reveal an excited state radicallike platinum precursor.

Synthesis, characterization and $\mathrm{Br}_{2}$ photoelimination studies have given some valuable insights with regards to the excited state photochemical pathways of the various platinum(IV) complexes. The ligand framework is crucial in deciding the sterics, electronics and excited state transitions in the platinum(IV) systems. In the case of organoplatinum(IV) complexes we see novel bromination of the aryl ring. The platinum activates the ring for electrophilic bromine substitution. This paves the way for novel brominated polycyclic aromatic carbon compounds. 


\section{REFERENCES}

1. Dasgupta, S.; Brunschwig, B. S.; Winkler, J. R.; Gray, H. B., Solar fuels editorial. Chem. Soc. Rev. 2013, 42 (6), 2213-2214.

2. Intergovernmental Panel on Climate Change, Climate Change 2014: Impacts, Adaptation, and Vulnerability. Summary for Policymakers. 2014.

3. Barber, J.; Tran, P. D., From natural to artificial photosynthesis. J. R. Soc. Interface 2013, 10 (81), 20120984/1-20120984/16.

4. Frischmann, P. D.; Mahata, K.; Wuerthner, F., Powering the future of molecular artificial photosynthesis with light-harvesting metallosupramolecular dye assemblies. Chem. Soc. Rev. 2013, 42 (4), 1847-1870.

5. Lewis, N. S.; Nocera, D. G., Powering the planet: chemical challenges in solar energy utilization. Proc. Natl. Acad. Sci. U. S. A. 2006, 103 (43), 15729-15735.

6. Kanan, M. W.; Surendranath, Y.; Nocera, D. G., Cobalt-phosphate oxygenevolving compound. Chem. Soc. Rev. 2009, 38 (1), 109-114.

7. Marinescu, S. C.; Bracher, P. J.; Winkler, J. R.; Gray, H. B., Solar fuels. AIP Conf. Proc. 2013, 1519 (Nobel Symposium 153: Nanoscale Energy Converters, 2012), 64-67.

8. U.S. Department of Energy, New Science for a Secure and Sustainable Energy Future. A Report from the Basic Energy Sciences Advisory Committee. 2008.

9. Office of Science, U.S. Department of Energy, Basic Research Needs for the Hydrogen Economy. Report on the Basic Energy Sciences Workshop on Hydrogen Production, Storage, and Use. 2003.

10. Thomassen, M.; Sandnes, E.; Boerresen, B.; Tunold, R., Evaluation of concepts for hydrogen - chlorine fuel cells. J. Appl. Electrochem. 2006, 36 (7), 813-819. 
11. Ledjeff, K.; Mahlendord, F.; Peinecke, V.; Heinzel, A., Development of electrode/membrane units for the reversible solid polymer fuel cell (RSPFC).

Electrochim. Acta 1995, 40 (3), 315-19.

12. Yeo, R. S.; McBreen, J.; Tseung, A. C. C.; Srinivasan, S.; McElroy, J., An electrochemically regenerative hydrogen-chlorine energy storage system: electrode kinetics and cell performance. J. Appl. Electrochem. 1980, 10 (3), 393-404.

13. Livshits, V.; Ulus, A.; Peled, E., High-power H2/Br2 fuel cell. Electrochem. Commun. 2006, 8 (8), 1358-1362.

14. Cook, T. R. Photochemical reductive elimination of halogen from transition metal complexes, Ph.D., Massachusetts Institute of Technology, 2010.

15. Teets, T. S. Halogen-Elimination Photochemistry and Oxygen-Activation Chemistry of Late Transition-Metal Complexes, Ph.D., Massachusetts Institute of Technology, 2012.

16. Dempsey, J. L.; Esswein, A. J.; Manke, D. R.; Rosenthal, J.; Soper, J. D.; Nocera, D. G., Molecular Chemistry of Consequence to Renewable Energy. Inorg. Chem. 2005, 44 (20), 6879-6892.

17. Teets, T. S.; Nocera, D. G., Photocatalytic hydrogen production. Chem Commun (Camb) 2011, 47 (33), 9268-74.

18. Cook, T. R.; Esswein, A. J.; Nocera, D. G., Metal-Halide Bond Photoactivation from a PtIII-AuII Complex. J. Am. Chem. Soc. 2007, 129 (33), 10094-10095.

19. Esswein, A. J.; Dempsey, J. L.; Nocera, D. G., A RhII-AuII Bimetallic Core with a Direct Metal-Metal Bond. Inorg. Chem. 2007, 46 (7), 2362-2364.

20. Esswein, A. J.; Veige, A. S.; Nocera, D. G., A Photocycle for Hydrogen Production from Two-Electron Mixed-Valence Complexes. J. Am. Chem. Soc. 2005, 127 (47), 16641-16651.

21. Teets, T. S.; Nocera, D. G., Halogen photoreductive elimination from gold(III) centers. J Am Chem Soc 2009, 131 (21), 7411-20. 
22. Cook, T. R.; McCarthy, B. D.; Lutterman, D. A.; Nocera, D. G., Halogen Oxidation and Halogen Photoelimination Chemistry of a Platinum-Rhodium Heterobimetallic Core. Inorg. Chem. 2012, 51 (9), 5152-5163.

23. Sharp, P. R.; Lee, H. B.; Karikachery, A. R. In Controlling Photochemical Halogen Elimination From Pt(IV) Complexes, American Chemical Society: 2009; pp MWRM-013.

24. Grimes, C. A., Varghese, Oomman K., Ranjan Sudhir, Light, Water, Hydrogen: The Solar Generation of Hydrogen by Water Photoelectrolysis. Springer Science: New york, 2008.

25. Szuromi, E.; Shan, H.; Sharp, P. R., Alkene Oxidation by a Platinum Oxo Complex and Isolation of a Platinaoxetane. J. Am. Chem. Soc. 2003, 125 (35), 1052210523.

26. Weliange, N. M.; Sharp, P. R., Ethylene Oxidation by a Platinum(II) Hydroxo Complex. Insights into the Wacker Process. Organometallics 2012, 31 (19), 6823-6833.

27. Weliange, N. M.; Szuromi, E.; Sharp, P. R., Proton-Catalyzed Oxo-Alkene Coupling: 2-Platinaoxetane Formation. J. Am. Chem. Soc. 2009, 131 (25), 8736-8737.

28. Sharp, P. R. In $\sigma$-Bonded transition metal complexes of polycyclic aromatic carbon compounds, John Wiley \& Sons, Inc.: 2012; pp 205-233.

29. Lee, H. B. Organo Nickel and Platinum Chemistry at the Edge of Corannulene, Ph.D., University of Missouri, 2007.

30. Karikachery, A. R.; Lee, H. B.; Masjedi, M.; Ross, A.; Moody, M. A.; Cai, X.; Chui, M.; Hoff, C. D.; Sharp, P. R., High quantum yield molecular bromine photoelimination from mononuclear platinum(IV) complexes. Inorganic chemistry 2013, 52 (7), 4113-9.

31. Heyduk, A. F.; Nocera, D. G., Hydrogen produced from hydrohalic acid solutions by a two-electron mixed-valence photocatalyst. Science (Washington, DC, U. S.) 2001, 293 (5535), 1639-1641. 
32. Cook, T. R.; Surendranath, Y.; Nocera, D. G., Chlorine photoelimination from a diplatinum core: circumventing the back reaction. J. Am. Chem. Soc. 2009, 131 (1), 2829.

33. Lee, C. H.; Cook, T. R.; Nocera, D. G., HX Addition and Photochemical H2 Elimination by Ni NHC Complexes. Inorg. Chem. 2011, 50 (3), 714-716.

34. Lin, T.-P.; Gabbai, F. P., Two-Electron Redox Chemistry at the Dinuclear Core of a TePt Platform: Chlorine Photoreductive Elimination and Isolation of a TeVPtI Complex. J. Am. Chem. Soc. 2012, 134 (29), 12230-12238.

35. Perera, T. A.; Masjedi, M.; Sharp, P. R., Photoreduction of Pt(IV) Chloro Complexes: Substrate Chlorination by a Triplet Excited State. Inorg. Chem. 2014, Ahead of Print.

36. Ross, A.; Sharp, P. R., Triphos Iridium(III) Halide Complex Photochemistry: Triphos Arm Dissociation. Inorg. Chem. 2013, 52 (21), 12645-12654.

37. Sharp, P. R. In Platinum(IV) photoelimination reactions: What is going on?, American Chemical Society: 2014; pp INOR-293.

38. Wickramasinghe, L. A.; Sharp, P. R., Photoreduction of Pt(IV) Halo-Hydroxo Complexes: Possible Hypohalous Acid Elimination. Inorg. Chem. 2014, 53 (3), 14301442.

39. Yoshida, T.; Matsuda, T.; Otsuka, S.; Parshall, G. W.; Peet, W. G., Tetrakis(Triethylphosphine)Platinum(0). 1990, 28, 122-123.

40. Morrison, R. T.; Boyd, R. N., Organic Chemistry. 6th ed. Prentice Hall: 1992; p $1360 \mathrm{pp}$.

41. Cakmak, O.; Demirtas, I.; Balaydin, H. T., Selective bromination of 1bromonaphthalene: efficient synthesis of bromonaphthalene derivatives. Tetrahedron 2002, 58 (28), 5603-5609. 
42. Clark, H. C.; Manzer, L. E., Reactions of ( $\pi-1,5-$

cyclooctadiene)organoplatinum(II) compounds and the synthesis of

perfluoroalkylplatinum complexes. J. Organometal. Chem. 1973, 59, 411-28.

43. Sharp, P. R. K., A. R.; Wickramasinghe, L. A.; Perera, T. A.; Masjedi, M.; Lee, H. B.; Ross, A.; Cai, X.; Chui, M.; Hoff, C. D. , Endergonic $\mathrm{Br}_{2}, \mathrm{Cl}_{2}$ and $\mathrm{HOCl}$ Photoelimination from Pt(IV) Complexes. In Inorganic Photophysics and Photochemistry - Fundamentals and Applications: Dalton Discussion 13, University of Sheffield, UK, September 10-12, 2012.

44. Shriver, D. F.; Atkins, P. W., Inorganic Chemistry, 5th Ed. Oxford University Press: 1996; p 864 pp.

45. Wang, B.-Y.; Raphael Karikachery, A.; Li, Y.; Singh, A.; Lee, H. B.; Sun, W.; Sharp, P. R., Remarkable Bromination and Blue Emission of 9-Anthracenyl Pt(II) Complexes. J. Am. Chem. Soc. 2009, 131 (9), 3150-3151.

46. Lexa, D.; Saveant, J. M.; Schaefer, H. J.; Su Khac, B.; Vering, B.; Wang, D. L., Outer-sphere and inner-sphere processes in reductive elimination. Direct and indirect electrochemical reduction of vicinal dibromoalkanes. Journal of the American Chemical Society 1990, 112 (17), 6162-6177.

47. Hatchard, C. G.; Parker, C. A., A New Sensitive Chemical Actinometer. II. Potassium Ferrioxalate as a Standard Chemical Actinometer. Proceedings of the Royal Society A: Mathematical, Physical and Engineering Sciences 1956, 235 (1203), 518-536.

48. Kurien, K. C., A modification to the ferrioxalate actinometer. Journal of the Chemical Society B: Physical Organic 1971, 2081.

49. SDBSWeb http://sdbs.db.aist.go.jp/sdbs/cgi-bin/cre index.cgi (National Institute of Advanced Industrial Science and Technology, April 25, 2014).

50. Murray, R. W.; Agarwal, S. K., Ozonolysis of some tetrasubstituted ethylenes. J. Org. Chem. 1985, 50 (24), 4698-702.

51. Clennan, E. L.; Chen, X., Reactions of an allylic sulfide, sulfoxide, and sulfone with singlet oxygen. The observation of a remarkable diastereoselective oxidation. J. Am. Chem. Soc. 1989, 111 (15), 5787-92. 
52. McCall, A. S.; Wang, H.; Desper, J. M.; Kraft, S., Bis-N-heterocyclic carbene palladium(IV) tetrachloride complexes: synthesis, reactivity, and mechanisms of direct chlorinations and oxidations of organic substrates. J. Am. Chem. Soc. 2011, 133 (6), 1832-1848.

53. Montalti, M.; Credi, A.; Prodi, L.; Gandolfi, M. T.; Editors, Handbook of Photochemistry - Third Edition. CRC Press LLC: 2006; p 650 pp.

54. Priestley, E. B.; Haug, A., Phosphorescence spectrum of pure crystalline naphthalene. J. Chem. Phys. 1968, 49 (2), 622-9.

55. Gautam, P.; Harriman, A., Internal rotation in auramine O. J. Chem. Soc., Faraday Trans. 1994, 90 (5), 697-701.

56. Kee, H. L.; Kirmaier, C.; Yu, L.; Thamyongkit, P.; Youngblood, W. J.; Calder, M. E.; Ramos, L.; Noll, B. C.; Bocian, D. F.; Scheidt, W. R.; Birge, R. R.; Lindsey, J. S.; Holten, D., Structural Control of the Photodynamics of Boron-Dipyrrin Complexes. J. Phys. Chem. B 2005, 109 (43), 20433-20443.

57. Modro, A.; Schmid, G. H.; Yates, K., Electrophilic additions to multiple bonds. 2. Medium effect on bromine additions to alkenes. J. Org. Chem. 1977, 42 (23), 3673-6.

58. Fukuzumi, S.; Kochi, J. K., Kinetics of electrophilic brominations. Mechanistic significance of the third-order term. Int. J. Chem. Kinet. 1983, 15 (3), 249-66.

59. Bellucci, G.; Bianchini, R.; Ambrosetti, R.; Ingrosso, G., Comparison of molecular bromine and tribromide ion as brominating reagents. 1. Kinetic evidence for different mechanisms of addition to cyclohexene. J. Org. Chem. 1985, 50 (18), 3313-18.

60. Islam, S. M.; Poirier, R. A., New insights into the bromination reaction for a series of alkenes. A computational study. J. Phys. Chem. A 2007, 111 (50), 13218-13232.

61. McMillen, D. W.; Grutzner, J. B., Radical Bromination of Cyclohexene in CCl4 by Bromine: Addition versus Substitution. J. Org. Chem. 1994, 59 (16), 4516-28.

62. Naae, D. G., Electrophilic bromination of fluoro olefins: syn vs. anti addition. $J$. Org. Chem. 1980, 45 (8), 1394-401. 
63. Zheldakov, I. L.; Ryazantsev, M. N.; Tarnovsky, A. N., Wavepacket Motion via a Conical Intersection in the Photochemistry of Aqueous Transition-Metal Dianions. $J$.

Phys. Chem. Lett. 2011, 2 (13), 1540-1545.

64. Balzani, V.; Carassiti, V., Photochemistry of some square-planar and octahedral platinum complexes. J. Phys. Chem. 1968, 72 (2), 383-8.

65. Balzani, V.; Manfrin, M. F.; Moggi, L., Photochemistry of coordination compounds. XVI. Hexabromoplatinate(IV) and hexaiodoplatinate(IV) ions. Inorg. Chem. 1967, 6 (2), 354-8.

66. Adamson, A. W.; Sporer, A. H., Photochemical reactions of some Co(III) and Cr(III) complexes. J. Am. Chem. Soc. 1958, 80, 3865-70.

67. Penkett, S. A.; Adamson, A. W., Flash photolysis of cobalt(III) acidopentaammine and of PtBr6-- and PtI6-- complexes. J. Am. Chem. Soc. 1965, 87 (11), 2514-15.

68. Glebov, E. M.; Grivin, V. P.; Plyusnin, V. F.; Venediktov, A. B.; Korenev, S. V., Photochemistry of $\mathrm{PtBr}_{6}{ }^{2-}$ complex in aqueous solutions. Formation and decay of $\mathrm{Br}_{2}$ radical anions. J. Photochem. Photobiol., A 2010, 214 (2-3), 181-187.

69. Glebov, E. M.; Plyusnin, V. F.; Venediktov, A. B.; Korenev, S. V., Photolysis of [PtBr6]2- complex in frozen methanol matrix. Russ. Chem. Bull. 2003, 52 (6), $1305-$ 1311.

70. Zheldakov, I. L. Ultrafast Photophysics and Photochemistry of Hexacoordinated Bromides of Pt(IV), Os(IV) and Ir(IV) in the Condensed Phase Studied by Femtosecond Pump-Probe Spectroscopy, Ph.D., Bowling Green State University, 2010.

71. Parshall, G. W.; Curtis, M. D.; Job, R. C., Azo, Diimide, and Hydrazine Complexes of Platinum. 1970, 12, 26-33.

72. Frye, H.; Kuljian, E.; Viebrock, J., Ligand rearrangement in cyclooctadiene by palladium(II) and platinum(II) $\pi$ complexes. Inorg. Chem. 1965, 4 (10), 1499-500. 
73. Wyrwa, R.; Poppitz, W.; Goerls, H., Mass spectrometric and X-ray studies on complexes of the type (COD) $\mathrm{PtX}{ }_{2}\left(\mathrm{X}=\mathrm{Cl}, \mathrm{Br}, \mathrm{I}, \mathrm{CH}_{3}, \mathrm{CH}_{2} \mathrm{CMe}_{3}, \mathrm{CH}_{2} \mathrm{SiMe}_{3}\right)$. Z. Anorg. Allg. Chem. 1997, 623 (4), 649-653.

74. $\quad$ Chang, X.; Lee, K.-E.; Il Jeon, S.; Kim, Y.-J.; Lee, H. K.; Lee, S. W., Bis(isothiocyanato)bis(phosphine) complexes of group 10 metals: reactivity toward organic isocyanides. Dalton Transactions 2005, (23), 3722.

75. Li, G.; Jiang, Q.; Zhang, L.; Zhou, Z.; Wang, S., Synthesis of dicarbonyldiphosphineplatinum( 0 ) complexes and their oxidative addition reaction with alkyl halide. Ниахие Хиеbao 1989, 47 (5), 449-55.

76. Kabalka, G. W.; Yang, K.; Reddy, N. K.; Narayana, C., Bromination of alkenes using a mixture of sodium bromide and sodium perborate. Synth. Commun. 1998, 28 (5), 925-929.

77. Comerford, J. J., Varian Instruments At Work 2003, 87, 1-8. 


\section{VITA}

Alice Raphael Karikachery was born in the beautiful and green state of Kerala, India. She grew up in the metropolis of Chennai, India. After graduating from high school Kendriya Vidyalaya CLRI, Chennai, she enrolled in the chemistry program of the Stella Maris College, Chennai. There she received her B.Sc. degree in Chemistry. She then completed her M.Sc. Chemistry degree from Loyola College, Chennai, under her advisor Dr. Fr. Boniface Jeyaraj. She later joined the Department of Chemistry at the University of Missouri, Columbia, to pursue the doctoral program in chemistry under the guidance and mentorship of Prof. Paul R. Sharp. Her graduate research has consisted of studying the synthesis, characterization and bromine photoelimination of organoplatinum(IV) complexes. 